\title{
A Regulatory Guide to Leasing, Permitting, and Licensing in Idaho, Montana, Oregon, and Washington
}

by

R. Gordon Bloomquist, Ph.D.

Washington State Energy Office

Prepared by the Washington State Energy Office in cooperation with the Idaho Department of Water. Resources, the Montana Department of Natural Resources and Conservation, and the Oregon Department of Energy

for

The Bonneville Power Administration Agreement No. DE-BI79-91BP16067 


\section{DISCLAIMER}

This report was prepared as an account of work sponsored by an agency of the United States Government. Neither the United States Government nor any agency Thereof, nor any of their employees, makes any warranty, express or implied, or assumes any legal liability or responsibility for the accuracy, completeness, or usefulness of any information, apparatus, product, or process disclosed, or represents that its use would not infringe privately owned rights. Reference herein to any specific commercial product, process, or service by trade name, trademark, manufacturer, or otherwise does not necessarily constitute or imply its endorsement, recommendation, or favoring by the United States Government or any agency thereof. The views and opinions of authors expressed herein do not necessarily state or reflect those of the United States Government or any agency thereof. 


\section{DISCLAIMER}

Portions of this document may be illegible in electronic image products. Images are produced from the best available original document. 
Disclaimer

This publication was prepared for use by interested developers and the Bonneville Power Administration. Neither the Bonneville Power Administration, nor the United States Department of Energy, nor the Washington State Energy Office, nor any of their employees, nor any of their contractors, subcontractors, or their employees, makes any warranty, expressed or implied, or assumes any legal liability or responsibility for the accuracy, completeness, or usefulness of any information presented. The views and opinions of authors expressed herein do not necessarily state or reflect those of the United States Government or any agency thereof. Reference herein to any specific product, process, or service by trade name, mark, manufacturer, or otherwise, does not necessarily constitute or imply its endorsement or recommendation or favoring by the United States Government or any agency thereof.

Please be aware that information included in this guide is subject to change. The Washington State Energy Office and Bonneville Power Administration are not to be held responsible for information that has changed since the printing of this guide. Each legislative session, new laws are developed and old laws are altered or repealed. Agencies may update their administrative codes, increase fees, or reorganize.

Also, there are resource protection requirements that are not listed in this guide. Requirements issued by special districts, such as sewer and water, diking, irrigation, port districts, etc., are not addressed herein. Some requirements may have been inadvertently left out, and in some cases, state agencies chose not to include those requirements that would apply only in rare cases.

The only way to be absolutely sure about permit requirements that apply to your project is to contact the appropriate resource agencies.

\section{Acknowledgements}

The Bonneville Power Administration and the Washington State Energy Office would like to pay special thanks to the author of this document, R. Gordon Bloomquist, Ph.D., of the Washington State Energy Office; to Alex Sifford of the Oregon Department of Energy for his help in producing the Oregon chapter; to Paul Cartwright of the Montana Department of Natural Resources and Conservation for his help in producing the Montana chapter; to Rick Sterling of the Idaho Department of Water Resources for his help in producing the Idaho chapter; to Jack Feuer of the Bureau of Land Management for his help in producing the federal chapter, and to Joyce Deshay of the Washington State Energy Office who helped with proofing. Special thanks also go to Char Gruessing of the Washington State Energy Office who helped to coordinate the information and was responsible for the word processing of this book. 


\section{Table of Contents}

\section{Introduction}

Typical Site Configurations …........................................................................1

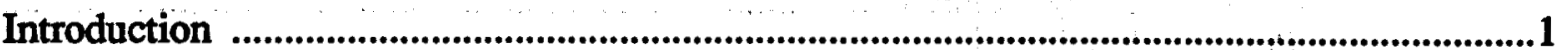

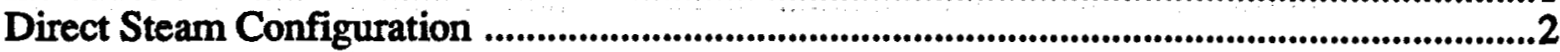

Flashed Steam Configuration ...............................................................................................................4

Binary Configuration ....................................................................................................................................6

Wellhead Binary Configuration .............................................................................................................

Chapter 1 - The Federal Process .....................................................................9

Legal Definition and Determination of Ownership ...........................................................9

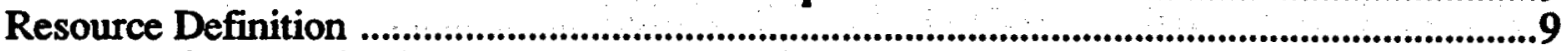

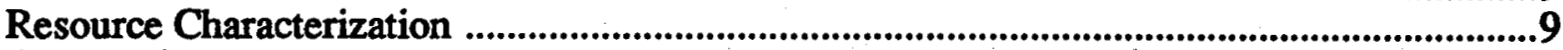



Obtaining Access to Geothermal Resources on Federal Lands ..................................................10

Environmental Protection .......................................................................................................................14

Environmental Impact Statements .................................................................................................21

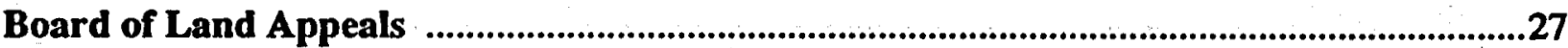

Appeal Procedure (43 CFR Subtitle A. Part 4) ……….............................................................27

Special Protection for Units of the National Park System .............................................................30



Competitive Leasing .............................................................................................................33

Noncompetitive Leasing ......................................................................................................33

Lease Limitations ........................................................................................................................36

Plans, Permits, Notices, Records, and Reports Required in Post-Lease Activities .................38

Surface Management ............................................................................................................41

Geothermal Resource Operations (GRO) Order ........................................................................4 41

Exploration .......................................................................................................................42

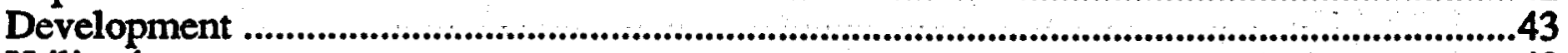

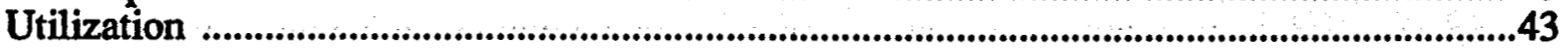

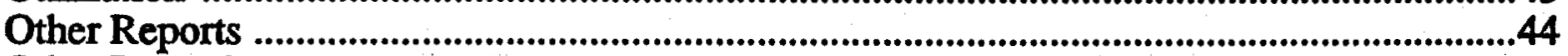

Other Records …................................................................................................................................45

Additional Federal Permitting and Licensing Requirements ..............................................45

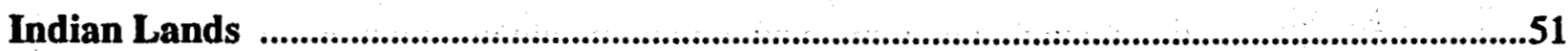

Underlying Rights and Principles: The Stevens Treaties ............................................................51

Indian Cultural and Archaeological Concerns ...............................................................................52

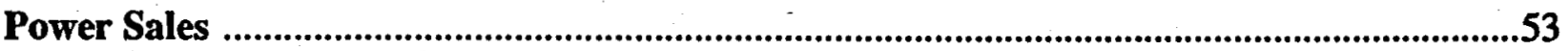

Federal Energy Regulatory Commission ..............................................................................................54

Public Utilities Regulatory Act (PURPA) Overview ...................................................................54 




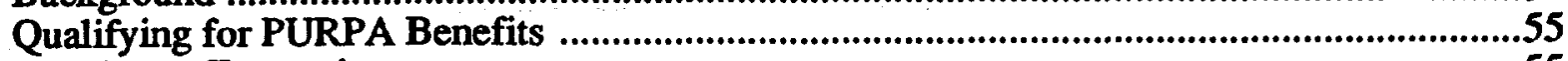

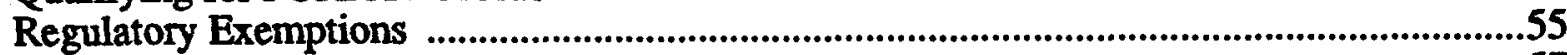



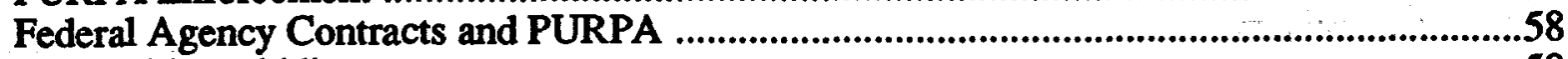

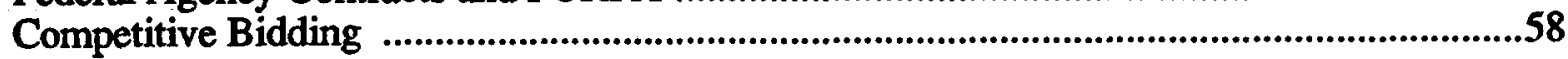

Regional Institutions ........................................................................................................59

Northwest Power Planning Council ............................................................................................60

Bonneville Power Administration .....................................................................................................61

Exhibit 1



Permit Summary Sheet_Idaho .......................................................................65

Chapter 2 - The Idaho State Process .........................................................66

Legal Definition and Determination of Ownership ................................................................66

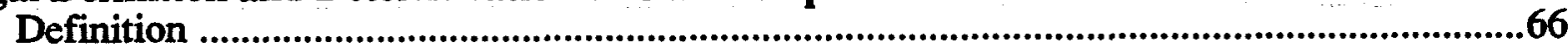



Obtaining Access to Geothermal Resources .................................................................67

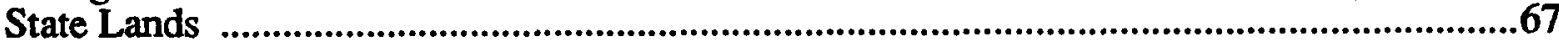

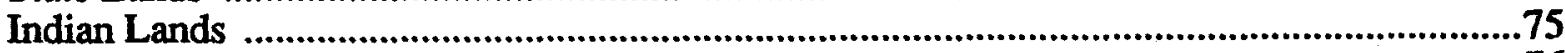



Idaho State Agencies' Responsibilities .........................................................................................79

Idaho State Permitting and Licensing Requirements ..................................................83

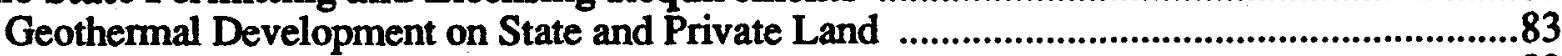

Major Facility Siting/Environmental Impact .............................................................8

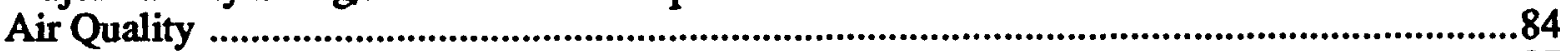

Water Quality/Water Use ..............................................................................................87

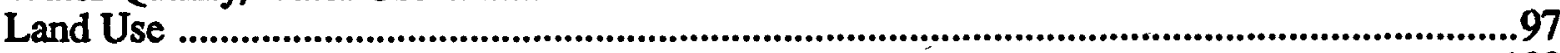

Construction





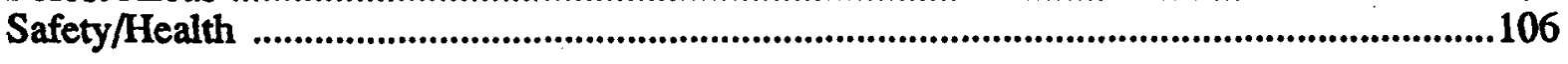

Local Government Permits .................................................................................................109

Determining Which Permits are Required ....................................................................110



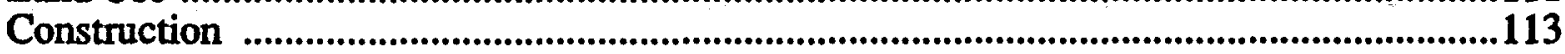

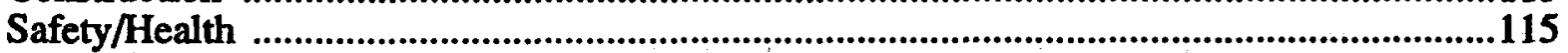

Other Permits 


\section{Permit Summary Sheet-Montana}

The Legal Definition and Determination of Ownership .......................................................118

Obtaining Access to Geothermal Resources .......................................................................119

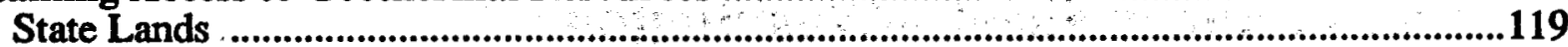

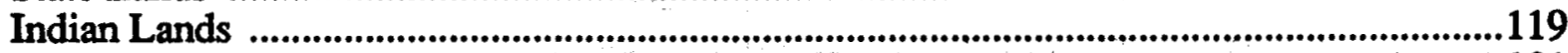



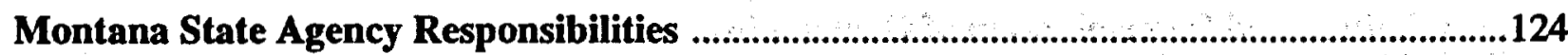

Montana State Permitting and Licensing Requirements ...................................................127

Major Facility Siting/Environmental Impact ..........................................................................138

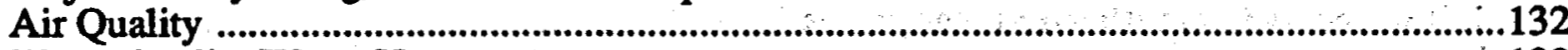

Water Quality/Water Use .........................................................................................132





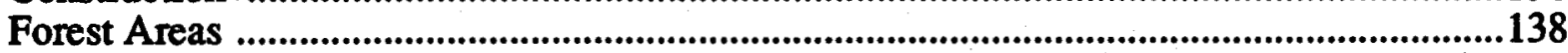

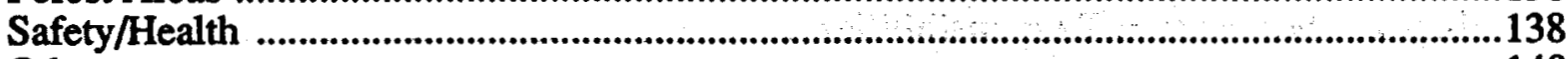

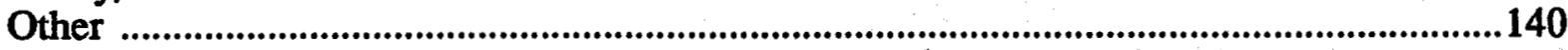

Local Permitting and Licensing Requirements .......................................................140

Determining Which Permits are Required ........................................................................142

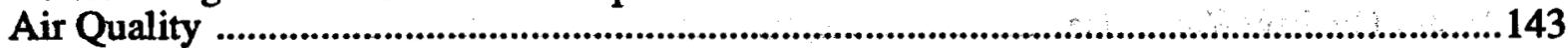

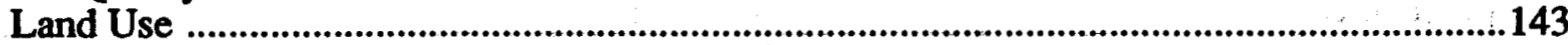

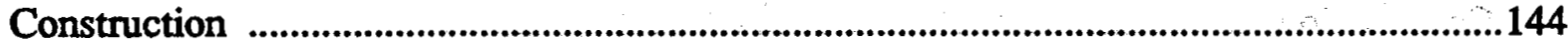

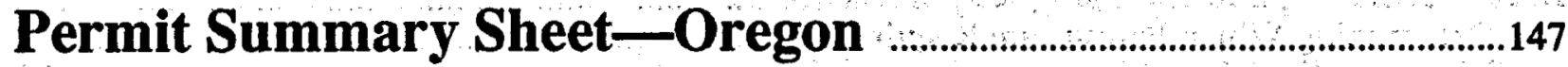

Chapter 4 - The Oregon State Process ..............................................148

Legal Definition and Determination of Ownership .............................................................148

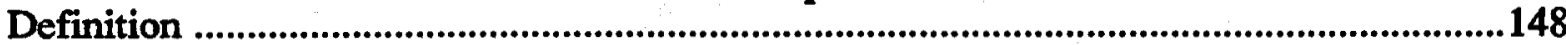

Ownership ....................................................................................................................149

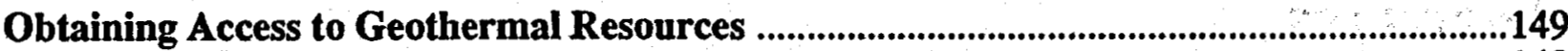

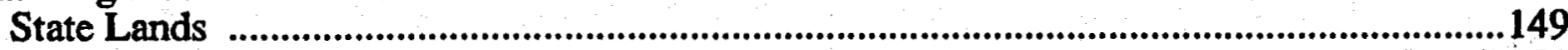

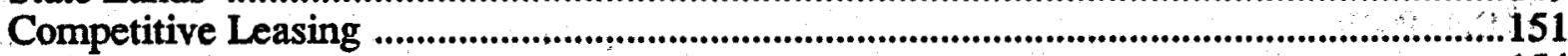

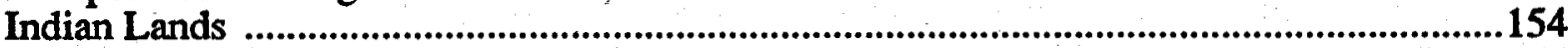

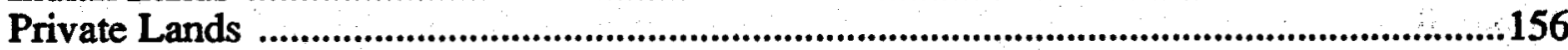

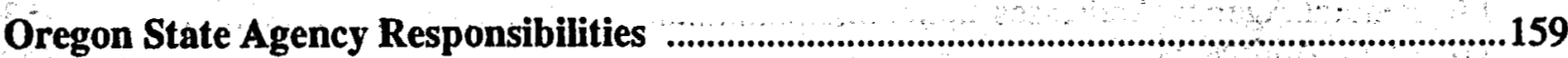

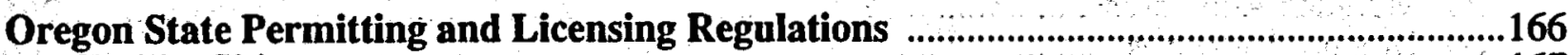

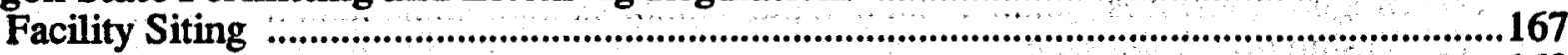

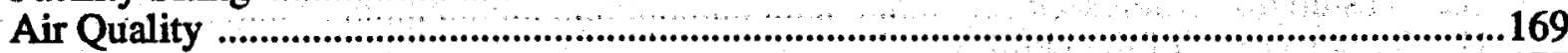

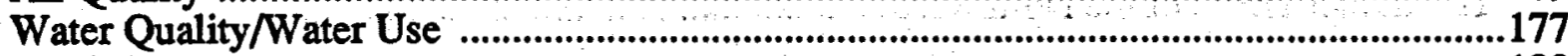

Land Use ................................................................................................................................180

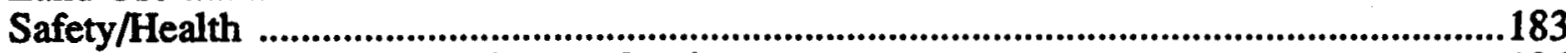

Other Permits, Licenses, or Agency Review .........................................................................186 
Local Permitting and Licensing Requirements 188

Determining Which Permits Are Required

Land Use

Permit Summary Sheet-Washington .................................................191

Chapter 5 - The Washington State Process ........................................192

Legal Definition and Determination of Ownership ..............................................................192

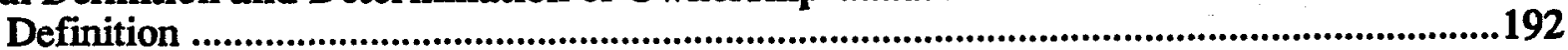



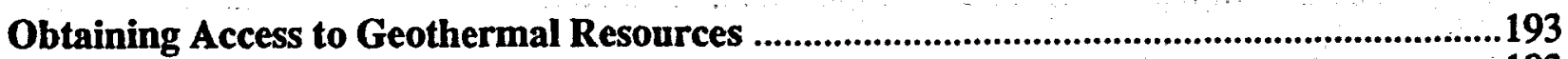



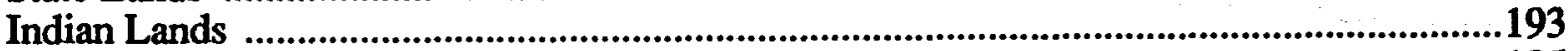

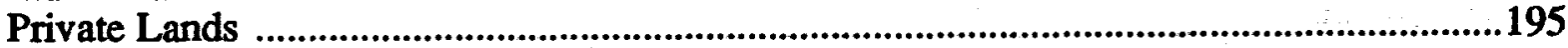

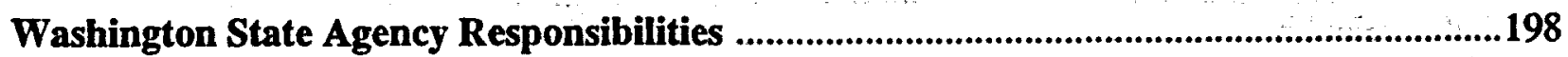

Washington State Permitting and Licensing Requirements ....................................................204

Major Facility Siting/Environmental Impact .............................................................204

Air Quality ..................................................................................................................208

Water Quality/Water Use .........................................................................................................212



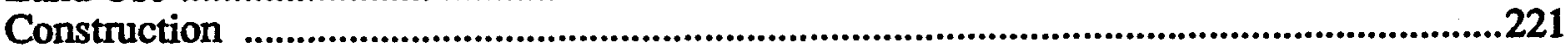

Safety/Health .......................................................................................................................222

Local Permitting and Licensing Requirements ......................................................................226

Determining Which Permits are Required ................................................................................228

Water Quality/Water Use ..........................................................................................................229

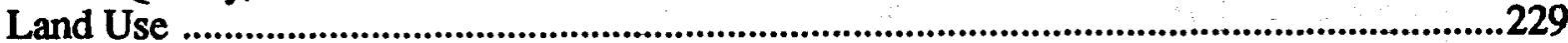

Construction .......................................................................................................................2230

Other Permits ..................................................................................................................................2232

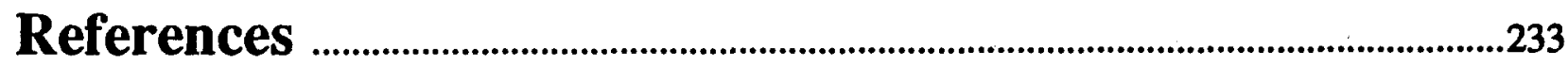

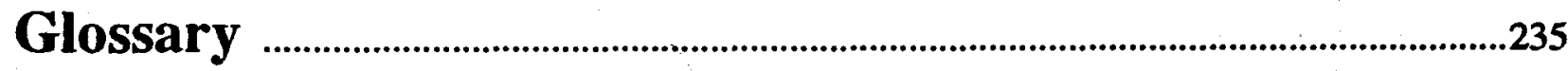

Appendices

1A Federal Agency Addresses .............................................................................................253

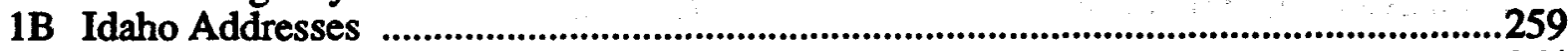

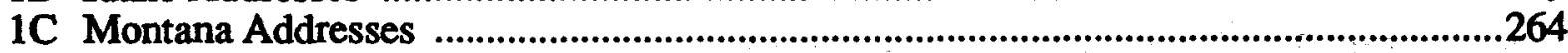

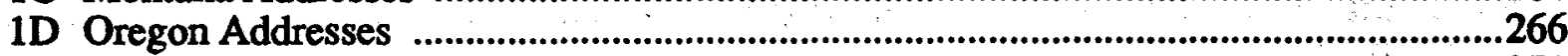

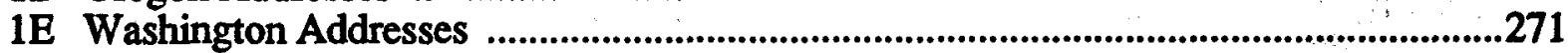

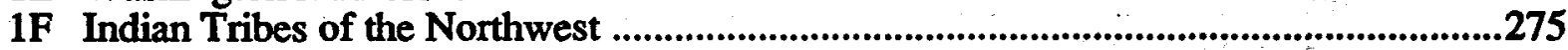




\section{Listing of Tables}

1 Resource Conditions and Conversion Process ...................................................................2

2 Lessee Exploration Expenditure Requirements ...................................................................37

3 Applications and Representatives Processing Times for Various Geothermal Activities-Federal

Allowable PSD Increments .

5 Summary of Air Quality Permits ......................................................................................171

6 Emission Standards and Regulations Included in an Air

Contaminant Discharge Permit (ACDP) ............................................................................171

7 Significant Emission Rates .........................................................................................173

8 Specific Emission Rates in Medford-Ashland AQMA .................................................174

9 Maximum Pollutants Levels Allowed by PSD Rules .......................................................175

10 PSD Allowable Increments-Maximum Allowable Increase in

Pollution Levels in Micrograms per Cubic Foot ...............................................................177

11 NPDES Permit Application Form ............................................................................178

12 Titles of LCDC Statewide Planning Goals ...................................................................180

13 When to Submit Land Use Compatibility Statements ..................................................182

14 New Industrial and Commercial Noise Source Standards ..............................................186

15 Industrial and Commercial Noise Source Standards for Quiet Areas ...........................186

16 Median Octave Band Standards for Industrial and Commercial Noise Sources ...........187

17 Possible State Permits or Evaluation Required for Development of

Geothermal Project .................................................................................................................209

\section{Listing of Figures}

1 Schematic Plan of a Geothermal Power Plant ...................................................................3

2 Flash Conversion System for Geothermal Power Plants ...................................................5

3 The Double-Flash Conversion System for Geothermal Power Plants ...............................5

4 Binary Geothermal Power Plant .........................................................................................6

5 Principal Pre-Lease Activities-Federal Geothermal Regulatory Process ........................13

6 NEPA Screening Process ...................................................................................................16

7 Generalized EIS Preparation Schedule …………............................................................25

8 Interagency Agreement for Implementing Section 115 of Public Law 99-591 ..............32

9 Competitive Lease Process-Geothermal Regulatory Process-Pre-Lease Activities .34

10 Noncompetitive Lease Process-Geothermal Regulatory Process-Pre-Lease Activities ..............................................................................................35

11 Idealized Timeline for a Hypothetical Oregon Site .............................................................39

12 Post-Lease Process-Geothermal Regulatory Process-Post-Lease Activities ..............40

13 Major Facility Siting Act-Application and Review Process ............................................129

14 Department of Environment Quality Permit Process Diagram .......................................168

15 Calendar for Timing Typical Permits-Minimum Time You Can Expect Before Approval ........................................................................................................169

16 Energy Facility Siting Council Application Process Diagram .......................................170

17 Oregon's Air Quality Regions and Air Quality Maintenance Areas ............................176

18 Local Government Land Use Approval - Land Use Planning and Permit Process .....181

19 Building Codes Agency-Building Permit Process .......................................................184

20 Application Process ................................................................................................................203

21 The SEPA Process ..................................................................................................................206 


\section{Introduction}

The goal of every geothermal project is the discovery and development of a geothermal reservoir capable of generating electricity or providing a source of thermal energy for direct applications including space heating, agriculture, and industrial processes. However, the actual exploration and development may appear to be a simple and straightforward process in comparison to the legal and institutional maze which the developer must navigate in order to obtain all of the federal, state, and local leases, permits, licenses, and approvals necessary at each step in the process. Finally, and often most difficult, is obtaining a contract for the sale of thermal energy, brine, steam, or electricity.

This guide is designed to help developers interested in developing geothermal resource sites in the Bonneville Power Administration Service Territory in the state of Idaho, Montana, Oregon, and Washington better understand the federal, state, and local institutional process, the roles and responsibilities of each agency, and how and when to make contact in order to obtain the necessary documents.

A majority of the responsibilities for issuing geothermal leases and the regulation of all exploration and development activities on federal lands lies with the Bureau of Land Management (BLM). The BLM has primary responsibility for available federal lands in accordance with the provisions of the Geothermal Steam Act of 1970, the National Environmental Protection Act of 1969 and the Endangered Species Act of 1973. The Surface Management Agency (SMA) (if other than the BLM) (e.g., United States Forest Service, U.S. Department of Defense, etc.) also has review responsibilities governing the issuance and administration of federal geothermal leases on properties under their jurisdiction. On nonfederal lands, the regulation of leasing and development activities lies with state and/or local agencies.

Once a lease has been secured for a particular geothermal resource area, exploration and development may follow. Before initiating any activity, however, the geothermal developer must obtain all necessary permits from the appropriate local, state, and federal regulatory agencies. The length of time necessary for permit application review and the number and type of permits required will vary depending upon the size of the project and the environmental impact it will have on the area.

\section{Typical Site Configurations}

\section{Introduction}

There are three primary types of geothermal power conversion systems. They are: 1) dry or direct steam, 2) flashed steam, and 3) binary. Each of these three will have differing impacts on 
the environment and thus each will be subject, in part, to differing federal, state, and local regulations. Of these, the latter two will probably be the most commonly used technologies in the Pacific Northwest.

Geothermal power conversion processes are dependent on steam content and temperature. Saturated steam or dry steam systems can be on the low end of the temperature scale, i.e., $175^{\circ} \mathrm{C}$ $\left(350^{\circ} \mathrm{F}\right)$, but nevertheless are capable of driving turbines directly. All remaining conversion systems are based on resources where only a fraction of the total volume is steam or are simply temperature dependent. In the cases of flash and binary technologies, temperature is the controlling factor. Table 1 lists resource conditions and conversion technologies for selected temperatures. Based on current information it is unlikely that dry steam resources will be discovered in the Northwest. A brief description of all technologies and typical site development configurations follows.

\section{Table 1}

\section{Resource Conditions and Conversion Processes}



\section{Direct Steam Configuration}

Geothermal resources made up of saturated water vapor are called vapor-dominated systems. The method used to exploit such reservoirs is shown schematically in Figure 1. Steam from 
production wells drives a steam turbine which in turn drives a generator, which produces electricity. The condensed liquid is then used in the cooling tower or sent to injection wells. For the sake of simplicity, it is assumed that the steam contains little or no non-condensable gases. Electricity generated is measured at the bus bar, with pump, fan, and other auxiliary loads subtracted. Well designed dry-steam power plants with condensing turbines operate with steam consumptions of about $7 \mathrm{~kg} / \mathrm{kWh}(15 \mathrm{lb} / \mathrm{kWh})$ or less.

The cooling tower shown in Figure 1 uses condensate for cooling and discharges large quantities of vapor into the atmosphere. It should be noted that a cooling tower must be supplied with make-up water during normal operation. This make-up water usually is derived from steam condensate, and amounts to approximately 6.4 million liters (1.7 million gallons) per $55 \mathrm{MW}$ of capacity per day. Cooling towers provide water at approximately $27^{\circ} \mathrm{C}\left(80^{\circ} \mathrm{F}\right)$ to the condensers, allowing efficient operation of condensing turbines. The condensed fluid is discharged through the injection wells if not required for cooling.

Because as much as $\mathbf{8 0}$ percent of the flow passing through the turbine may be lost to the atmosphere, a careful water budget must be established for each plant. Alternatively, the cooling tower operation may be accounted for separately with water from an outside source.




Steam gathering systems supplying power plants at The Geysers in northern California are no longer than $2 \mathrm{~km}(6,650 \mathrm{ft}$.) to control loss of availability of the steam from the wellhead to the turbine. Gathering pipe diameters range from $254 \mathrm{~mm}$ (10 in.) at the wellhead to $914 \mathrm{~mm}$ (36 in.) at the plant. A steam well will supply anywhere from 34,000-159,000 kilograms per hour $(\mathrm{kg} / \mathrm{h})(75,000-350,000 \mathrm{lbs} / \mathrm{h})$. Approximately seven production wells are connected to the system supplying the required 450 metric tons per hour $(t / h r)(1,000,000 \mathrm{lbs} / \mathrm{hr})$ of steam for a typical $55 \mathrm{MW}$ power plant. Half or less the number of production wells, e.g., two to four wells, are generally required for injection at typical $55 \mathrm{MW}$ plants in The Geysers.

Non-condensable gases, if present, are removed from the condenser by steam-jet ejectors or vacuum pumps, then vented and injected back into the resource or treated to remove $\mathrm{H}_{2} \mathrm{~S}$.

\section{Flashed Steam Configuration}

Dry steam or vapor-dominated systems are rare. There are only five dry steam fields which have been developed in the world. Hot water or liquid-dominated geothermal systems are much more common. These systems contain small amounts of steam, but most of the resource is under pressure in the fluid phase. In a typical flash plant, geothermal fluids are brought to the surface under pressure and moved through a succession of flash vessels where the pressure is reduced, allowing a portion of the fluid at each vessel to separate into steam.

A flash power conversion system which separates the fluid mixture into streams of vapor and liquid is shown schematically in Figure 2. After flashing, the single-flash system is similar to the system shown in Figure 1. In the flash system, both the separated brine and the spent condensate are exhausted from the system for injection.

The efficiency of flash plants is substantially lower than that of dry steam plants. This is due to the small amount of steam available in the resource, and because the hot water fraction of the mixture is discarded from the plant without being used. In an effort to fully utilize these liquiddominated resources, additional flash stages can be added to the process. The result is a double-, triple-, or multi-flash system which more fully utilizes the resource. The double-flash system is shown schematically in Figure 3. A high-pressure, high temperature fluid from the well separates into a mixture of steam and liquid, then the liquid is throttled in the flash vessel to produce additional streams of vapor and liquid at lower pressure. The steam from both the separator and the second stage flash tank goes to the turbogenerator, while the liquid is injected back into the reservoir. Ultimately, the steam portion is injected as condensate after passing through the condenser and cooling tower. Condensate is used in the cooling tower and evaporative water demand is approximately $300 \mathrm{gpm}$ per $10 \mathrm{MW}$ of capacity.

Another approach to increasing efficiency is to extract heat from the brine through the use of a binary system after steam is removed through flashing. 




Figure 2 - Flash Conversion System for Geothermal Power Plants

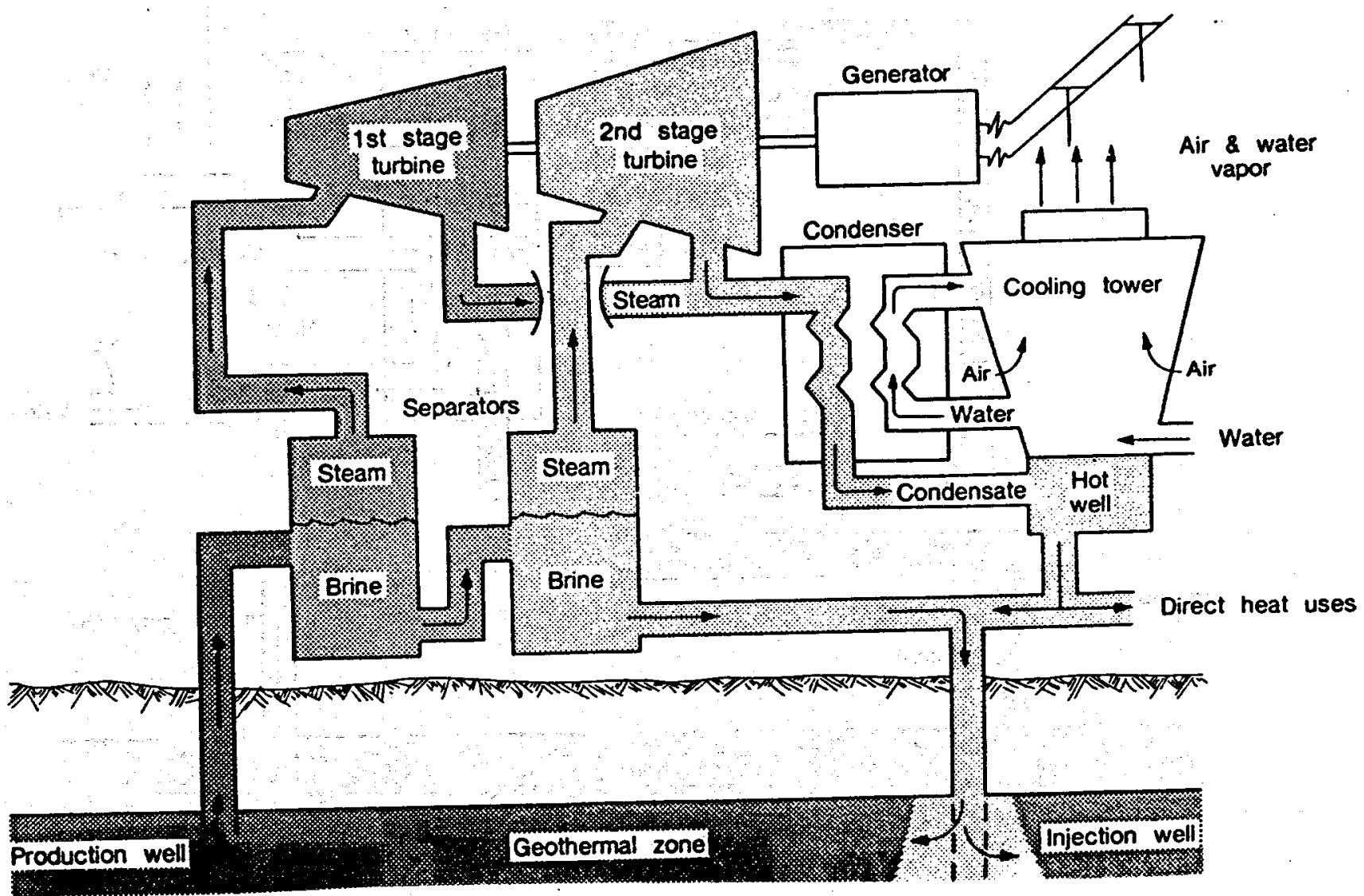

Figure 3 - The Double-Flash Conversion System for Geothermal Power Plants 
Many flash units are designed as modular units. Auxiliary or parasitic plant loads total about 1 MW (10 percent of gross capacity). Most plants operate at 90 to 95 percent of capacity and with an availability of $95+$ percent.

Existing power plants in southem Califomia, Nevada, and Utah provide good examples of typical flash steam configurations.

\section{Binary Configuration}

Rather than use steam directly to drive a turbine, binary generation systems use secondary working fluids. In these systems the geothermal resource is piped to a heat exchanger where the working fluid is vaporized to drive a turbine. The resource, after passing through the heat exchanger, is injected back into the reservoir. The use of working fluids has several advantages: higher efficiency than steam at low temperatures, non-corrosive working fluid in the turbine, and less expensive turbine for a given output. Such "closed loop" systems do not expose the geothermal resource to air, water, or the surface resulting in significant environmental attractiveness. Geothermal resources as low as $90^{\circ} \mathrm{C}\left(194^{\circ} \mathrm{F}\right)$ can use the organic Rankine cycle to convert heat into electricity. Figure 4 shows a binary system schematic.

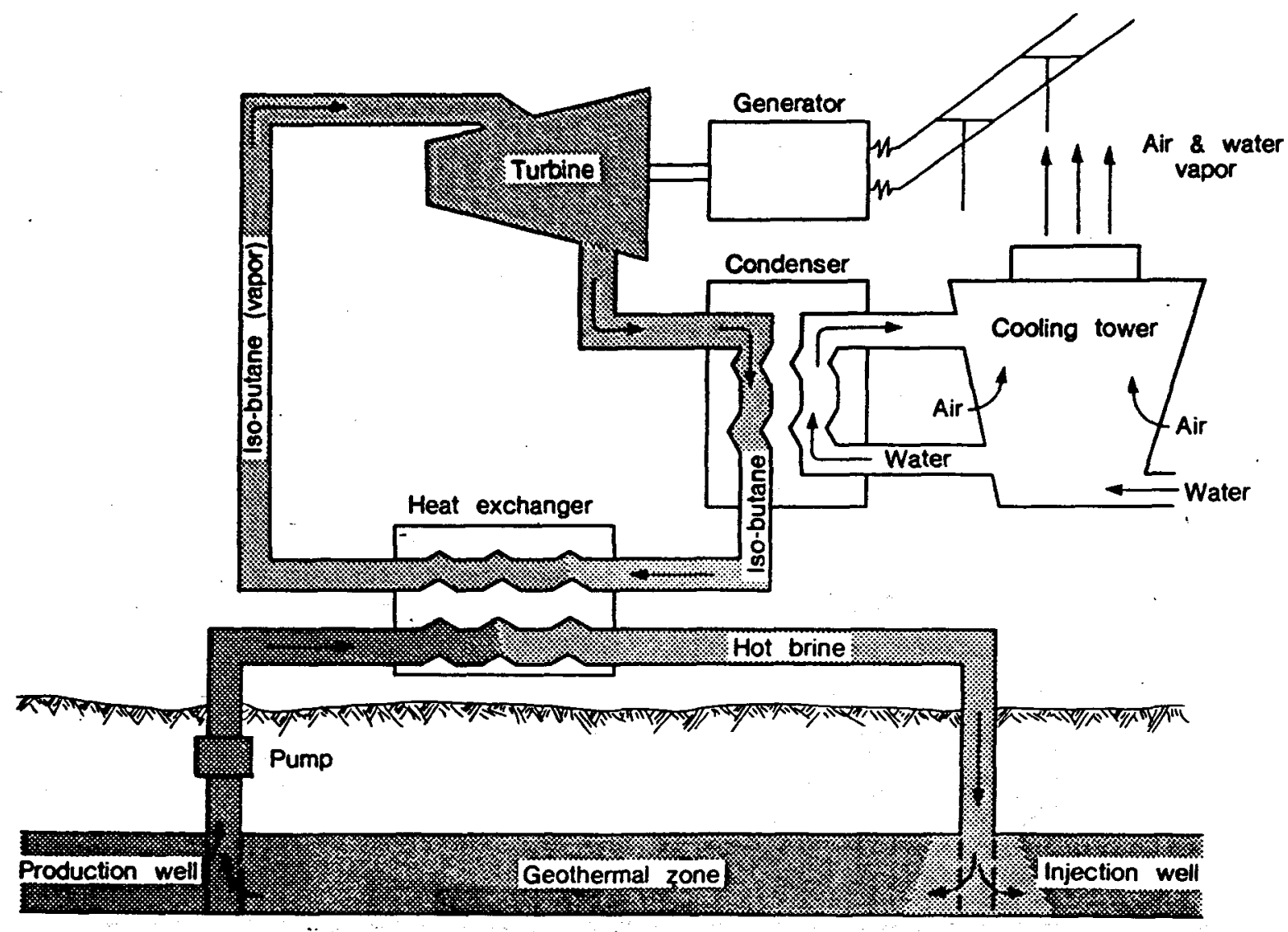

Figure 4 - Binary Geothermal Power Plant 
In the organic Rankine cycle, a halocarbon or hydrocarbon working fluid (chosen according to resource temperature) is vaporized by the heat stream in the heat exchanger. The pressurized vapor expands through the organic vapor turbine which is coupled to a generator. The low pressure turbine exhaust passes through the condenser, and the resultant fluid is pumped back to the vaporizer by the working fluid cycle pump.

The efficiency of the Rankine cycle is low because resources used in this application possess low enthalpy (low intrinsic heat content), and a secondary conversion process is involved. Achievable efficiencies of the organic Rankine cycle range from approximately 3 to 18 percent.

Since a number of commonly used working fluids are flammable, this necessitates the installation of fire protection equipment and safeguards not normally associated with the steam power plants. This equipment results in additional capital costs.

Cooling of the working fluid can be accomplished through the use of either wet or dry cooling towers. With a wet cooling tower, a configuration very similar to that used with direct steam or flash discussed above would be used and water requirements will be of a similar magnitude.

Air cooling, on the other hand, permits advantageous use of cold air as a cooling medium, particularly in the winter time, thereby increasing thermal efficiency and power output by reducing condensing pressures in the season when power is most needed. Parasitic loads are estimated to average 32 percent of gross capacity on a yearly basis. Capacity and availability normally exceed 90 percent per $10 \mathrm{Ma}$.

Most binary plants are of modular construction thus maximizing both portability and salvage values while allowing for quick construction and commercial viability.

\section{Wellhead Binary Configuration}

The difference between wellhead binary plants and simple binary plants is size and portability. Plants up to $10 \mathrm{MW}$ in size have been called wellhead binary, all others simply binary. Although wellhead flash systems are available, binary systems offer greater promise of development due to the wider range of operating temperatures under which they can operate efficiently. Advantages of small binary power plants over large $(55 \mathrm{MW})$ plants are several: smaller capital investment; short time for design, procurement, and construction; modular construction; and reduced resource, technical, and institutional risks. 



\section{Chapter 1 \\ The Federal Process}

\section{Legal Definition and Determination of Ownership}

\section{Resource Definition}

Geothermal resources are related to water, gas, and minerals; to the surface and subsurface estates, and to both water rights and mineral titles. How geothermal resources are defined affects other resource definitions as well as all aspects of regulation.

Legislative bodies in defining geothermal resources have been faced with two basic tasks. The first task was to describe the physical properties that distinguish geothermal resources from other natural resources and thus clearly establish ownership and what is subject to geothermal leasing, taxation, and development regulations. Secondly, legislative bodies were forced to relate geothermal resources to groundwater, subsurface minerals, and other established resources. An ideal resource definition would look forward to future leases, exploration, and development activities while, at the same time, looking backward in order to place geothermal resources into the framework of leases, reservations, and property titles inherited from the past (Sacarto, 1976).

How well legislation accomplished these tasks has had a profound influence upon resolving conflicts of ownership and, of course, upon the development of leasing procedures and exploration and development regulations.

The Federal Geothermal Steam Act of 1970 (Public Law 91-581) defined geothermal resources as follows:

'Geothermal steam and associated geothermal resources' means (i) all products of geothermal processes, embracing indigenous steam, hot water, and hot brines; (ii) steam and other gases, hot water, and hot brines resulting from water, gas, or other fluids artificially introduced into geothermal formations; (iii) heat or other associated energy found in geothermal formations; and (iv) any by products derived from them (30 USC 1001).

The federal definition defines byproduct so as to exclude oil, hydrocarbon gas, and helium.

\section{Resource Characterization}

As the legal definition recognizes, geothermal resources are similar in many respects to water, minerals, and gas. This has caused considerable disagreement-including litigation-over the essential nature of the resource and corresponding ownership rights. 
The federal government, in passage of the Geothermal Steam Act of 1970, avoided the question of how geothermal resources should be characterized. The Steam Act chose instead to direct the Justice Department to bring suit to quit title to geothermal resource ownership. The courts were asked to decide whether or not geothermal resources had been reserved to the federal govermment as part of the mineral estate. The action brought by the Justice Department (United States of America vs. Union Oil Company of California) began in 1971, and a verdict in favor of the United States was reached in October 1977 under the title Ottobonie vs. the United States of America. The courts clearly decreed that geothermal resources are mineral in nature and belong to the mineral estate.

\section{Ownership}

After a site for geothermal resource development has been identified, land surface and subsurface ownership must be determined. In many cases, ownership of the surface and geothermal or mineral rights is the same. However, in some instances, the geothermal or mineral estates have been severed from the surface ownership. When the estates have been separated, the potential developer must negotiate with both owners (Bloomquist, 1985).

The federal government claims geothermal ownership wherever it holds the mineral estate, either jointly with the surface estate or as a mineral reservation where the estates have been severed. It is unclear, however, whether federal ownership extends to groundwater useful for direct application purposes when the estates are severed. In most cases, the states have primary control over groundwater resources pursuant to the establishment of a federal enclave.

The states, on the other hand, have taken differing approaches to the assignment of ownership, depending on whether geothermal resources are characterized as water, mineral, or sui generis (unique unto itself) (see Chapters 2,3,4, and 5).

In all cases, the filing of lease application should be preceded by a competent title search as a determination of ownership is essential to securing the necessary development rights. It is best to consult a qualified title insurance company or an attomey.

\section{Obtaining Access to Geothermal Resources on Federal Lands}

Federal agencies make major decisions about energy project development on federal lands. This is particularly true in the western U.S. where much land is federally owned. Environmental legislation guides these agencies' land management policies. The Wilderness Act of 1964 prohibits geothermal development in wildemess areas (16 USC 1131, et. seq.). The Multiple-Use, Sustained Yield Act, and the Taylor Grazing Act set an early policy direction for management of federal lands (16 USC 528; 43 USC 325([a]). New siting strategies also may be shaped by land management legislation. 
Two acts which have the greatest impact on geothermal development on federal lands are the National Forest Management Act (NFMA) of 1976 and the Federal Land Policy and Management Act (FLPMA) (15 USC 1600, et. seq.; 43 USC 1701, et seq.). The U.S. Forest Service is the principal agency responsible for implementing NFMA. The NFMA requires assessments of renewable resources on lands managed by the U.S. Forest Service. The assessment includes resource inventories and analyses which are used in land management plans for each Forest Service unit.

FLPMA requires the Secretary of Interior to inventory resources and prepare land use plans based on those resource assessments. The Bureau of Land Management (BLM) is the principal agency responsible for implementing this act.

If energy facilities are not included in the plans, conflicting or preemptive land uses could prevent development of prime resource sites. When these facilities specifically are included as an accepted use, federal agencies must develop a procedure to allow for private energy resource development on federal lands. One option outlined in FLPMA authorizes sale of public lands for such development. If prime resource areas are not sold, they may be leased and this is by far the most common method by which private developers gain access to public lands.

Surface access and the priority right to explore, develop, and use geothermal resources on federal lands are acquired through an "Offer to Lease and Leases for Geothermal Resources" issued by the BLM. Pursuant to the Geothermal Steam Act of 1970 (amended 1988), the Secretary of the Interior can issue leases for the development and use of geothermal resources on certain federal lands. Exempted from leasing are lands that are:

(a) Administered under the National Park Systems

(b) Within a national recreation area

(c) In a fish hatchery administered by the Secretary (of Interior), wildlife refuge, wildlife range, game range, wildlife management area, or waterfowl production areas or for lands acquired or reserved for the protection and conservation of fish and wildlife which are designated as rare and endangered species by the Secretary; or under active consideration for inclusion in categories (a), (b), or (c) as evidenced by the filing of an application for a withdrawal or a proposed withdrawal

(d) Tribally or individually owned Indian trust or restricted lands, within or without the boundaries of Indian reservations

(e) Lands for which the Secretary determines that geothermal exploration, development, or utilization is reasonably likely to result in a significant adverse effect on a significant thermal feature within a unit of the National Park System 
(f) Lands within the Island Park Known Geothermal Resource Area (Idaho)

(g) Lands subject to the leasing prohibition provided under Section 43 of the Mineral Leasing Act (30 U.S.C. 22b-3) which includes:

(1) Lands recommended for wilderness allocation by the surface management agency

(2) Lands within a Bureau of Land Management wildemess study area

(3) Lands designated by Congress as wildemess study areas, except where leasing is specifically allowed to continue by statute designating the area

(4) Lands within areas allocated for wilderness or further planning in Executive Communications 1504, Ninety-sixth Congress (House Document numbered 96-119) unless such lands are allocated to uses other than wilderness by a land and resource plan or have been released to uses other than wildemess by an Act of Congress (CFR Part 3201.1-6)

(5) Department of Defense lands, and other lands selected by the Secretary (of Interior).

Wilderness areas, designated after 1970 subsequent to the 1970 Geothermal Steam Act, may be leased in accordance with terms of the Wilderness Act of 1964 (Clark, 1985).

Access is provided through the issuance of exploration or prospecting permits, noncompetitive leases for lands of unknown potential, and through competitive bidding for particularly valuable resource areas, designated by the Secretary of Interior as Known Geothermal Resource Areas (KGRA) on the basis of geology, a discovery of geothermal resources, or competitive interest.

Limited exploration involving "casual use" activities may be conducted before securing a lease by notifying the local BLM District Office or the Forest Supervisor's Office. Casual use refers to activities such as geologic mapping and spring sampling that are transitory and do not appreciably disturb the land.

The principal pre-lease activities of the federal leasing process are summarized in Figure 5 (Bloomquist, 1986).

The federal government employs a three-tiered approach to providing access to public lands. Prospecting permits, the first tier, are available to developers from the appropriate surface management agency (SMA). Pre-lease exploration activities may begin upon approval of a "Notice of Intent to Conduct Resource Exploration Operations" (NOI) (Form 3200-9) from the 
Pre-Lease Exploration

Applicant files Notice of Intent to conduct geothermal exploration

Surface Management Agency consults with other agencies on proposed activities<smiles>CCCC</smiles>

Approval of permit to explore by Surface Management Agency<smiles>C1CCCCC1</smiles>

Exploration activity undertaken<smiles>CCCC</smiles>

Surface Management Agency notification of compliance subsequent to completion of exploration activity

\section{Noncompetitive Leasing}



Applicant submits non competitive application to BLM

Surface Management Agency notified of lease offering

no EA existing, EA conducted by Surface Management Agency in consultation with other agencies

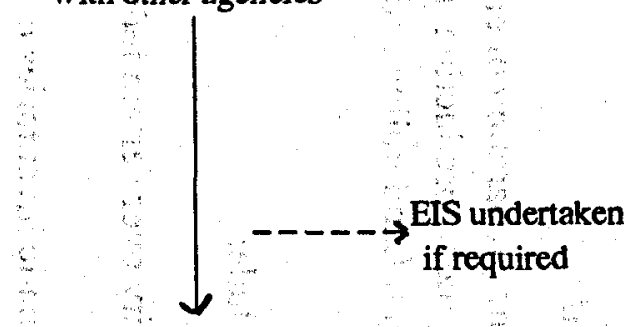

Lease recommendations given by Surface Management Agency

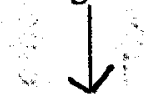

Lease approved by BLM

Lease issued
Competitive Leasing

KGRA designated by BL̃M



BLM with both agencies determines priorities for processing KGRAs<smiles>CCCC</smiles>

If no EA existing, EA conducted on specific KGRA by Surface Management Agency in consultation with others

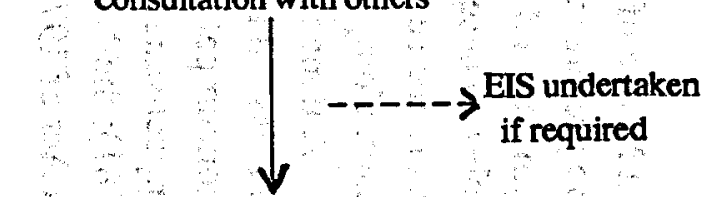

BLM - Publications of lease sale date<smiles>CCCC</smiles>

Lease Sale<smiles>CCCC</smiles>
BLM reviews bids<smiles>C1CCC1</smiles>

Lease awarded to highest bidder by BLM

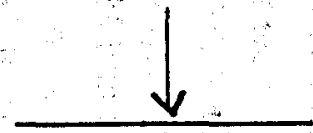


authorized officer of BLM.* Exploration under a Notice of Intent (NOI) gives a non-exclusive right to conduct operations on federal land, but no preference for a lease. A NOI is required from the BLM and allows for geological, geochemical, and geophysical surveys, as well as the drilling of exploration or temperature gradient holes. These permits are non-exclusive and are not convertible to leases. Noncompetitive leases are the second tier, and are available on lands of unknown potential to the first qualified applicant. Competitive leases, the third tier, are available in KGRAs** to the highest qualified bidder. A noncompetitive lease application can, however, be rejected at anytime up to when the lease is issued if the area is declared a KGRA by the Bureau of Land Management. The issuance of noncompetitive and competitive leases is contingent upon the completion of an environmental impact statement in accordance with provisions of the Geothermal Resource Act of 1970 (P.L. 91-581); the National Environmental Policy Act of 1969 (P.L. 91-190); and the Endangered Species Act of 1973, (P.L. 93-205).

\section{Environmental Protection}

The BLM has broad responsibilities in the preparation of environmental statements related to geothermal leasing, exploration, development, production, and electrical transmission. BLM activities are guided primarily by the Federal Land Policy and Management Act of 1976 (90 Stat. 274.43 U.S.C. 1701) (FLPMA).

The major provisions under FLPMA include:

1. Broad management responsibility over certain federal lands;

2. Conducting periodic and systematic inventories of the public lands and the resources they contain;

3. Comprehensive land use planning to ensure proper use of the land and the resources they contain; and

4. Management activities to protect scientific, scenic, historical, ecological, environmental, air and atmosphere, water, and archaeological values.

In addition to the above policy, BLM is also responsible for ensuring compliance with applicable state and federal laws and regulations including, for example:

\footnotetext{
FSuch approval may require an environmental review. The notice requires site-specific information concerning exploration plans and appropriate bond(s) (Form 3000-4) or other bond assurance. The approved notice requires compliance with all applicable federal and state laws and local ordinances. When the exploration activities are complete, a "Notice of Completion of Exploration Operations" (Form 3200-10) must be filed with the BLM.

**KGRA is defined as "an area in which the geology, nearby discoveries, competitive interest, or other indications would, in the opinion of the Secretary of the Interior, engender a belief in men who are experienced in the subject matter that the prospects for extracting of geothermal steam or associated geothermal resources are good enough to warrant expenditures of money for that purpose" (United States Geological Survey, 1979).
} 
Clean Water Act of 1977 (22 USC 1251 et seq.)

Clear Air Amendments of 1970 (as amended 1976) (42 USC 7401 et seq.)

Clear Air Act of 1990 (P.L. 101-1531)

Endangered Species Act of 1973 (16 USC 1531)

National Historic Preservation Act of 1966 (amended 1976) (16 USC 470)

Antiquities Act of 1906 (as amended) (P.L. 59-209; 16 USC 432, 433)

National Environmental Policy Act of 1969 (P.L. 91-190; 42 USC 4321)

Geothermal Steam Act of 1970 (amended 1988) (P.L. 91-581)

Archaeological Resources Protection Act of 1979 (P.L. 96-95; 16 USC 470a et seq.)

Native American Religious Freedom Act of 1978 (42 USC 1996)

Wilderness Act of 1964 (16 USC 1131 et seq.)

In the preparation of environmental impact statements for the leasing of fluid minerals, including geothermal resources, guidelines require BLM to identify public lands that are:

1. Open to fluid mineral leasing subject to standard terms and conditions;

2. Open to fluid mineral leasing subject to seasonal constraints or other special restrictions;

3. Open to fluid mineral leasing subject to no surface occupancy and similar major constraints; or

4. Closed to fluid mineral leasing.

The first step in evaluating a request for a geothermal lease or in making a decision to offer geothermal leases for sale is to review the proposed action for NEPA compliance (see Figure 6). Although certain actions are exempt from NEPA compliance, all geothermal leasing, as a result of Conner vs. Burford (see below), is subject to the need for an EIS.

\section{National Environmental Policy Act of 1969}

On January 1, 1970, the National Environmental Policy Act of 1969 (P.L. 91-190) became law. The Act declares that all practical means will be applied to conduct federal activities in a way that will promote the general welfare and harmony of the environment. Section 102 of the Act directs that to the fullest extent possible: (1) the policies, regulations, and public laws of the United States shall be interpreted and administered in accordance with the policies set forth in this Act, and (2) all agencies of the Federal Government shall:

(C) include in every recommendation or report on proposals for legislation and other major Federal activities significantly effecting the quality of the human environment, a detailed statement by the responsible official on 


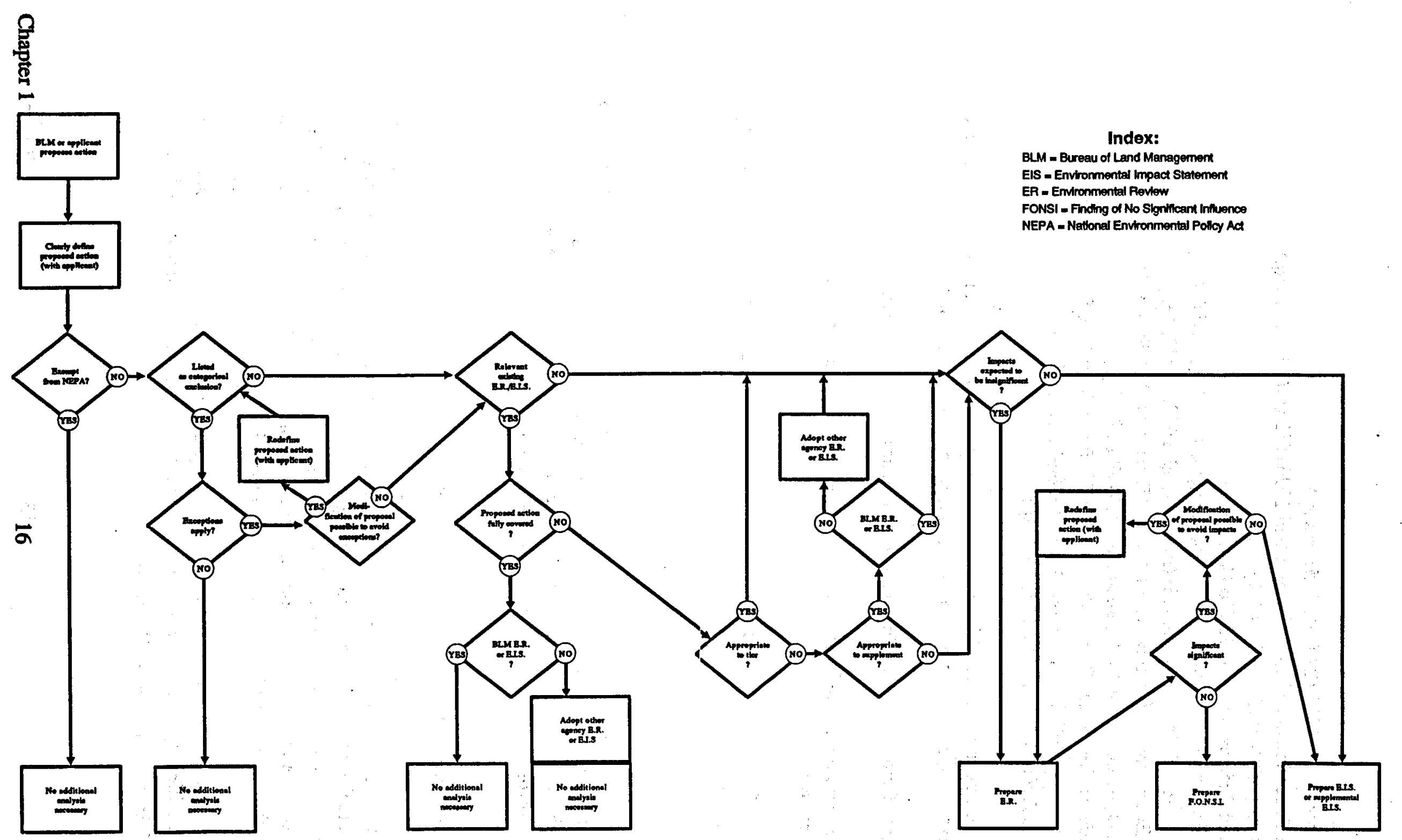

密

Figure 2: NEPA Screening Process 
(i) the environmental impact of the proposed action,

(ii) any adverse environmental effects which cannot be avoided should the proposed action be implemented,

(iii) alternatives to the proposed action,

(iv) the relationship between local short-term use of man's environment and the maintenance and enhancement of long-term productivity, and

(v) any irreversible or irretrievable commitments of resources which would be involved if the proposed action should be implemented.

\section{Endangered Species Act of 1973}

In 1973, the United States Congress passed the Endangered Species Act (P.L. 93-205) declaring that:

(a) Findings

(1) various species of fish, wildlife, and plants in the United States have been rendered extinct as a consequence of economic growth and development untempered by adequate concems and conservation;

(2) other species of fish, wildlife, and plants have been so depleted in numbers that they are in danger of or threatened with extinction;

(3) these species of fish, wildlife, and plants are of esthetic, ecological, educational, historical, recreational, and scientific value to the nation and its people;

(4) the United States has pledged itself as a sovereign state in the international community to conserve to the extent practicable the various species of fish or wildlife and plants facing extinction...

(5) encouraging the states and other interested parties, through federal financial assistance and a system of incentives, to develop and maintain conservation programs which meet national and international standards is a key to meeting the nation's international commitments and to better safeguarding, for the benefits of all citizens, the nation's heritage in fish, wildlife, and plants.

(b) Purposes

The purposes of the Act are to provide a means whereby the ecosystem upon which endangered and threatened species depend may be conserved to provide a program for the conservation of endangered and threatened species, and to take such steps as may be appropriate to achieve the purposes of the treaties and convention set forth in subsection (a) of this section. 
(c) Policy

(1) It is declared to be the policy of Congress that all federal departments and agencies shall seek to conserve endangered and threatened species and shall utilize their authorities in furtherance of the purposes of the Act.

(2) It is further declared to be the policy of Congress that federal agencies shall cooperate with state and local agencies to resolve water resource issues in concert with conservation of endangered species.

\section{$\S 1536$ Interagency Cooperation}

(a) Interior (Secretary)

(1) The Secretary of the Interior shall review other programs administered by him and utilize such programs in furtherance of the purposes of the Act. All other federal agencies shall, in consultation with and with the assistance of the Secretary, utilize their authorities in furtherance of the purposes of the Act by carrying out programs for the conservation of endangered and threatened species.

(2) Each federal agency shall in consultation with and assistance of the Secretary, ensure that any action authorized, funded, or carried out by such agency (agency action) is not likely to jeopardize the continued existence of any endangered or threatened species or result in the destruction or adverse modification of the habitat of such species...unless the agency has been granted an exemption for such action. In fulfilling the requirements of this paragraph each agency must use the best scientific and commercial data available.

(3) Subject to guidelines established by the Secretary, a federal agency shall consult with the Secretary on any proposed agency action if there is reason to believe that an endangered or threatened species may be present in the area affected by a project and the implementation of such action will likely affect such species.

(4) Each federal agency shall confer with the Secretary on any agency action which is likely to jeopardize the continued existence of any species proposed to be listed under section 1533 of this Act or result in destruction or adverse modification of critical habitat proposed to be designated for such species.

(c) Biological assessment

(1) To facilitate compliance with the requirements of subsection (a)(2), each federal agency shall request of the Secretary information whether any species which is listed or proposed to be listed may be present in the area of such proposed action. If, based on the best scientific and commercial data available, the Secretary advises that such species may be present, the agency shall conduct a biological assessment for the purpose of identifying any endangered or threatened species which is likely to be affected by such action. Such assessment must be completed within 180 days if a permit or license application is involved (unless the agency provides the applicant with a written statement setting forth the estimated length of the proposed extension and the reason therefore). The assessment must be completed before any permit or license is granted and before 
any contract for construction is entered into or before any construction is begun. Such assessment may be undertaken as part of a federal agency's compliance with the requirements of section 102 of the National Environmental Policy Act of 1969 (42 U.S.C. 4332).

(2) Any person who may wish to apply for an exemption under provisions of the Act for that action may conduct a biological assessment to identify any endangered species or threatened species which is likely to be affected by such action. Any such biological assessment must, however, be conducted in cooperation with the Secretary and under the supervision of the appropriate federal agency.

\section{Geothermal Steam Act of 1970}

In 1970, the Geothermal Steam Act (P.L. 91-581) was passed and made provisions for the leasing of federal lands for geothermal exploration and development. In as much as the leasing of federal lands for exploration and development would have a significant impact on the environment, a programmatic environmental impact statement (EIS) was required before provisions of the Act could be put into effect. The EIS was completed in 1974 and leasing initiated.

The Bureau of Land Management (BLM) is responsible for administering leasing of federal lands under provision of the Geothermal Steam Act of 1970. BLM, in basing its decisions as to the issuance of leases on federal properties in compliance with provisions of NEPA, contented that an EIS was unnecessary as the action was solely a matter of granting or denying of leases. This in itself, in BLM's opinion, would have no environmental impact. Surface-disturbing activities related to exploration and development would be subject to further environmental analysis as required by NEPA. In addition, standard and special stipulations would prevent or mitigate much of the adverse environmental impacts related to exploration and development activities. The case Conner vs. Burford, however, resulted in major changes in BLM leasing policy for oil and gas, as well as geothermal.

\section{Conner vs. Burford}

In the case Conner vs. Burford ( 848 F,2d 141, 9th Cir. 1988) the court concluded that the leasing of federal lands for oil and gas exploration without completing an EIS pursuant to provisions of NEPA and a comprehensive biological opinion considering all stages of activity pursuant to provisions of the Endangered Species Act of 1973 \& 2 et seq., 16 U.S.C.A. $\$ 1531$ et seq., was in violation of both the National Environmental Policy Act of 1970 and the Endangered Species Act of 1973.

The court ruled that the "uncertainties and speculative nature of...exploration did not provide justification for not requiring preparation of an environmental impact statement in connection with issuance of...leases. "Issuance of.,.leases...required filing of environmental impact statement, not withstanding stipulations in leases which limit lessees' ability to conduct certain sur- 
face operations on leases which did not contain "no surface occupancy" stipulations and thus did not reserve to govermment absolute right to prevent all surface-disturbing activities" (National Environmental Policy Act of $1969, \S 10242$ U.S.C.A. $\$ 4332$ ).

The court did find, however, that "Issuance of...leases...which contained no surface occupancy" stipulation prohibiting lessees from occupying or using the surface of leased lands did not require filing of environmental impact statement. Granting of such leases did not constitute an irreversible commitment of resource, and modification or removal of such stipulation would require preparation of an EIS (National Environmental Policy Act of 1969, $\$ 102,42$ U.S.C.A. $\$ \S 4332$ ).

The court concluded that the standard and special stipulations, referred to collectively as "mitigation stipulations," authorize the government to impose reasonable conditions on drilling, construction, and other surface-disturbing activities; unlike no surface occupancy (NSO) stipulations; however, mitigation stipulations do not authorize the government to preclude such activities altogether. The mitigation stipulation in non-NSO leases permit reasonable regulation of surface-disturbing activities to reduce their impact on the environment. These stipulations do not, however, preclude the lessees from engaging in surface-disturbing activities altogether. They may, for example, build roads and drill...subject only to reasonable mitigation measures.

The court reasoned that NEPA requires a comprehensive EIS at the lease..stage to project and analyze the cumulative effects of successive, interdependent steps culminating in...development and production (see Thomas vs. Peterson, 753F.2d 754, 757 [9th Cir. 1985]). Otherwise, the "court feared" a piecemeal invasion...would occur, followed by the realization of a significant and irreversible impact."

The court therefore concluded that the purpose of an EIS is to apprise decision makers of the disruptive environmental effects that may follow from their decision at the time when they "retain a maximum range of options."

In assessing the impact of issuance of leases pursuant to the Endangered Species Act, the Fish and Wildlife Service was required to consider all phases of such action, including postleasing activities, in rendering biological opinions (Endangered Species Act of 1973, \& 7(a)(2), 16 U.S.C.A., \& 1536(a)(2)).

From the above court decision it is now clear that any and all further decisions by BLM regarding the issuance of leases whether they be competitive or noncompetitive, must be preceded by full compliance with provisions of the National Environmental Policy Act of 1969 and the Endangered Species Act of 1973, including the preparation of an EIS prior to lease issuance.

Compliance with the need for an EIS for geothermal leasing and development can be accomplished either through the preparation of a new EIS or by using an existing environmental analysis. 


\section{Environmental Impact Statements}

\section{Preparing Environmental Impact Statements}

When a proposed action is projected to have a significant impact on the quality of the human environment, an environmental impact statement (EIS) must be prepared. An EIS is intended to provide decision makers and the public with a complete and objective evaluation of significant environmental impacts, both beneficial and adverse, resulting from a proposed action and all reasonable alternatives. An EIS is a major vehicle for fulfilling the substantive environmental goals set forth in NEPA.

For proposals initiated within the BLM, e.g., a decision to hold a lease sale, the EIS is prepared prior to any commitment to the proposal.

For externally initiated proposals, e.g., a request for leasing, the EIS is prepared after receipt of an essentially completed application (40 C.F.R. 1502.5 and 516 DM 4.3).

\section{Using Existing Environmental Analyses}

According to BLM policy existing environmental analyses should be used in analyzing impacts associated with a proposed action to the extent possible and appropriate. This approach builds on work that has already been done, avoids redundancy and provides a coherent and logical record of the analytical and decision making process (NEPA Handbook, 14-1790-1).

Several questions must be addressed before an existing environmental analysis may be used:

1. Have any relevant environmental analyses related to the proposed action been prepared (e.g., RMP/EIR programmatic EIS)?

2. Who prepared and cooperated in the preparation of the analyses (e.g., the BLM, Forest Service, etc.)?

3. Do any of the existing analyses fully analyze the proposed action and alternatives?

In determining whether an existing EIS covers a proposed action currently under consideration, the criteria are as follows:

1. The new proposed action is a feature of or essentially the same as the alternative selected in the document being reviewed.

2. A reasonable range of alternatives to the new proposed action was analyzed in the document being reviewed, i.e., there are no unresolved conflicts involving alternative resource uses for the new proposed action. 
3. The circumstances or information upon which the document being reviewed is based are still valid and germane to the new proposed action, i.e., there is no significant change in circumstances and no significant new information.

4. The methodology or analytical approach used in the document being reviewed is appropriate for the new proposed action.

5. The direct and indirect impacts of the new proposed action are not significantly different than, or are essentially the same as, those identified in the document being reviewed.

6. The new proposed action of implementation would not significantly change the cumulative impact analysis, i.e., is within the range of reasonably foreseeable developments contemplated in the document being reviewed.

7. Public involvement in the document being reviewed provides appropriate coverage for the new proposed action.

If all the above criteria are met, additional analysis will not be necessary to satisfy NEPA requirements. If the BLM was not a formally cooperating agency on the EIS prepared by another agency, the BLM would have to adopt the document in order to use it for NEPA compliance (see NEPA Handbook for details on BLM adoption).

If not all the criteria above are met, a new document must be prepared. It may, however, be appropriate to tier to, supplement, or incorporate by reference parts or all of the existing environmental documents. If no environmental statement has been prepared, preparation of a new statement will have to be initiated.

\section{Tiering (40 C.F.R. 1508.28)}

Tiering is used to prepare new, more specific, or more narrow environmental documents without duplicating relevant parts of previously prepared, more general, or broader documents. The more specific or more narrow environmental documents incorporate by reference the general discussion and analysis from the broader document and concentrate on the issues and impacts of the project which are not specifically covered in the broader document.

Tiering is appropriate when:

1. The analysis for the proposed action will be a more site- or project-specific refinement or extension of the existing analysis.

2. The decisions associated with the existing environmental document will not be changed as a result of the tiering. 


\section{Supplementing (40 C.F.R. 1502.9(c))}

Supplements to an existing draft or final EIS are prepared when additional environmental analysis is needed. The relationship between the supplement and the existing EIS is lateral, i.e., the proposed action and alternatives are analyzed to the same level of specificity and detail. A supplemental EIS is often used to address alternatives not previously analyzed and may lead to new decisions.

A supplement is generally prepared when:

1. There are substantial changes in the proposed action that are relevant to environmental concerns (40 C.F.R. 1502.9 (c)(1)(i))

2. There are significant new circumstances or facts relevant to environmental concerns and bearing on the proposed action or its impacts which were not addressed in the existing analyses (40 C.F.R. 1509.0 (c)(1)(i))

3. Using another agency's environmental document and additional analysis is needed

An example of when supplementing an EIS may be appropriate is a substantial change is proposed for a planned transmission line, pipe line, or power plant which was analyzed in a previous EIS.

\section{Using Another Agency's ER or EIS (40 C.F.R. 1506.3)}

The purpose of using another agency's environmental document for NEPA compliance is to reduce paperwork, eliminate duplication, and/or make the process more efficient. Use of another agency's EIS is accomplished by either formally cooperating in its development or adopting all or parts of the EIS.

Part or all of another agency's environmental document may be used for NEPA compliance if both of the following criteria are met:

1. The environmental document meets Council of Environmental Quality, Department of Interior, and Bureau of Land Management standards.

2. The BLM has performed an independent review of the environmental document and has concluded that it has addressed BLM concerns and suggestions.

When another federal agency intends to prepare an EIS and the BLM has or possibly may have jurisdiction, the BLM should formally request designation as a cooperating agency. BLM must, however, prepare its own record of decision (ROD). 
Incorporating by reference is a technique used to avoid redundancies in analysis and to reduce the bulk of NEPA documents. Both ERs and EISs may incorporate previous analyses by reference. Materials or analyses incorporated by reference are not limited to NEPA documents. Special technical or professional studies and analyses prepared by the BLM, other federal agencies, state, local, or tribal governments; or private interests may be incorporated by reference. If a document incorporated by reference is at the heart of the EIS, it should be circulated for comment as part of the draft.

\section{Preparing a New EIS}

When a new Environmental Impact Statement relating to leasing of federal lands or development activities on such lands must be prepared, the process includes the following (see Figure 7):

1. Scoping the EIS to focus the analysis on significant issues and reasonable altematives.

2. Publishing a notice of intent in the Federal Register to notify persons or agencies interested in, or affected by, a proposed federal action and to seek information and/or participation in scoping.

3. Conducting the analysis and preparing the draft EIS.

4. Issuing the draft EIS for public and other agency comments.

5. Analyzing the comments and preparing the final EIS.

6. Issuing the final EIS for comment.

7. Reaching and recording the decision.

Once the draft EIS is completed and has gone through internal review, it is printed, filed with the EPA, and issued for public review and comment. A period of at least 60 days from the date the draft EIS is transmitted to EPA must be allowed for public review. A notice as to the availability of the draft EIS is normally published in the Federal Register and a press release is usually prepared for national and/or local media to announce the availability of the draft and to announce any public meetings or hearings.

Copies of the draft EIS are distributed to the Department of Interior; other federal agencies; individuals, organizations, and agencies on the mailing list; and to participants in public meetings.

Public meetings/hearings are usually held during the draft review period to receive comments on the draft. Once all meetings/hearings are held and public and agency comments received, the input is recorded and a final EIS is prepared taking into account all relevant comments that are substantive and relate to inadequacies or inaccuracies in the analysis or methodologies used, identify new impacts or recommend reasonable new alternatives or mitigation measures, or involve substantive disagreements on interpretation of significance.

If substantive comments are received, the official in charge must determine whether the new impacts, new altematives, or new mitigation measures should be analyzed in either the final EIS, a supplement to the draft EIS, or a completely revised and recirculated draft EIS. 
Activity

Prepare Notice of Intent (NOI) Publish NOI in Federal Register Public Scoping Meeting Comment Period

Close Comment Period on Scoping Prepare Implementation Plan Internal Review Implemt. Plan EPA/Dept. of Interior Approval of Implementation Plan Analysis and Preparation of Preliminary Draft EIS Internal Review of Preliminary

Draft EIS and Rewrite Draft EIS to Interior for

Preliminary Review

Revise Draft EIS Based on

Any Interior Comments

Internal Review Official Draft EIS Interior Review and Approval of Official Draft EIS

Print and Distribute Draft EIS

Announce Availability of Draft EIs Draft EIS Filed with EPA, Notice of Availability (NOA) in

Federal Register

Comment Period (45 days)

Evaluate Comments and

Prepare Responses

Letter to Public-Feedback on

Comments and Responses and Next Steps

Prepare Final EIS

Intemal Review of Preliminary

Final EIS and Rewrite

Preliminary Final EIS to

Interior for Review

Revise Final EIS Based on

Interior Comments

Internal Review of Official

Final EIS

Interior Review and Approval of Official Final EIS

Prepare Decision Record (ROD) for 1992 Resource Program

Intemal Review of Preliminary

ROD and Rewrite

Interior Review Preliminary ROD

Print and Distribute Final EIS

Announce Availability of

Final EIS

Final EIS Filed with EPA.

(NOA) in Federal Register

Intemal Concurrence on ROD

to Interior for Approval

of Environmental Content

Administrator Signs ROD After

30-day No-action Period

Announce the Decision and

Availability of ROD

Publish ROD in Federal Register
Month

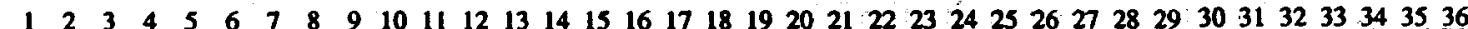



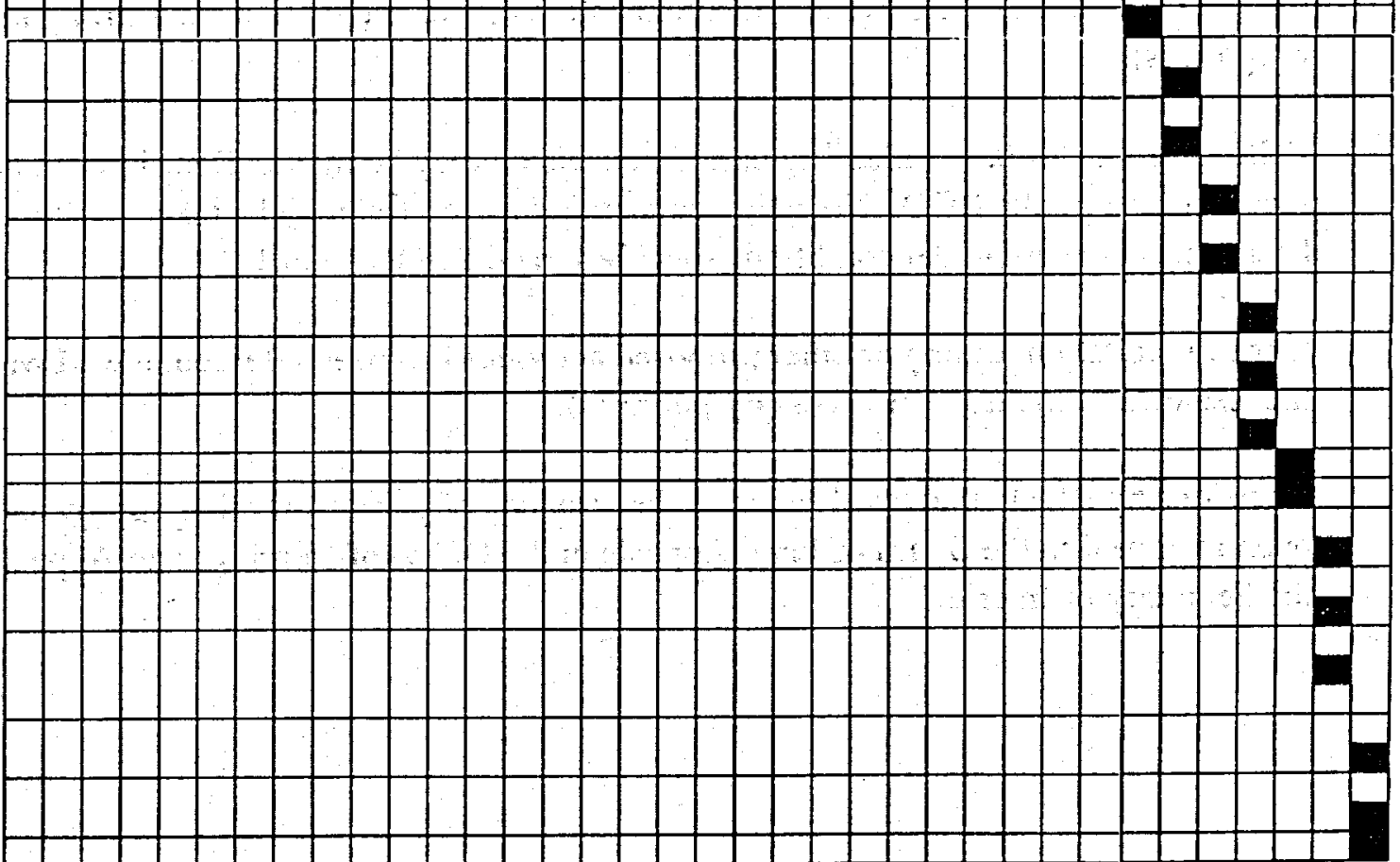


Once it is determined that a final EIS should be prepared, all substantive comments, changes, corrections, and revisions are incorporated into a preliminary final EIS. The document is then circulated for internal concurrence and must be approved by the manger responsible for authorizing the action covered by the EIS.

Following approval, the EIS is printed, filed with the EPA, and distributed to the public. A notice of availability must be published in the Federal Register and a press release is issued to national and/or local media. Copies are generally made available to all substantive commentors and others who have a strong interest in the proposal(s).

The Record of Decision (ROD) is not issued until the 30-day no-action period has lapsed following the publication of the EPA notice on the final EIS in the Federal Register and other programspecific requirements, if any, have been met.

Comments on the final EIS, if any, must be reviewed to determine if they have merit, e.g., identify significant issues not previously addressed or introduce new significant information. If substantial comments are received, the manager responsible for preparing the EIS must deter-mine whether a supplemental draft EIS or supplemental final EIS is warranted. If not, the commentor(s) are advised, if possible and appropriate, of the availability date for the ROD.

The public must be advised of the availability of the ROD and a notice of availability is published in the Federal Register as well as in national and/or local press. Copies of the decision are made available to substantive commentors and to others known to have a strong interest in the proposal(s).

Following the 30-day availability period, a decision may be made. Decisions on an EIS are recorded in a public ROD. No action concerning a proposal may be taken until the ROD has been issued, except under conditions specified in 40 C.F.R. 1506.1 .

Once the ROD on leasing or other proposed activities has been released, the BLM may approve the issuance of the lease or necessary permit(s).

Decisions by BLM related to leasing or the issuance of permits or other approvals are, however, open to appeal to the Board of Land Appeals in the Office of Hearings and Appeals, Office of the Secretary of Interior. 


\section{Board of Land Appeals}

\section{Appeal Procedure (43 CFR Subtitle A. Part 4)}

The Director of the Office of Hearing and Appeals is an authorized representative of the Secretary of Interior for the purpose of hearing, considering, and making determinations concerning matters within the jurisdiction of the Department of Interior involving appeals and other reviews and as such acts on behalf of the Secretary.

The Board of Land Appeals has final authority in decisions related to:

1. the use and disposition of public lands and their resources including land selections arising under the Alaska Native Claims Settlement Act, as amended

2. the use and disposition of mineral resources in certain acquired lands of the United States

3. the conduct of surface coal mining under the Surface Mining Control and Reclamation Act of 1977

The government is represented in the cases brought before the Appeals Board by Department of Interior council designated by the Solicitor of the Department or by council for other agencies, bureaus, or offices of the federal government in the same manner as a private advocate represents a client.

Any person desiring to appear as amicus curiae in any proceedings shall make a timely request stating the grounds for such request. Permission to appear before the Board, if granted, will be for such purposes as established by the Director or the Appeals Board in the proceeding.

Any party to a case who is adversely affected by a decision of an Office of the Bureau of Land Management or of an administrative law judge has the right to appeal to the Board, except:

1. as otherwise provided in Group 2400 of Chapter II of this title

2. to the extent that decision of the Bureau of Land Management officers must first be appealed to an administrative law judge under $\$ 4.470$ and Part 4100 of this title

3. where the decision has been approved by the Secretary

A person who wishes to appeal to the Board must file in the office of the officer who made the decision (not the Board) a notice that he wishes to appeal. A person served with the decision being appealed must transmit the notice of appeal in time for it to be filed in the required office within $\mathbf{3 0}$ days after the date of service. If a decision is published in the Federal Register, a person other than the person served with the decision must transmit a notice of appeal in time for it to be filed within $\mathbf{3 0}$ days after the date of publication. No extension of the time will be granted for filing the notice of appeal. 
The notice of appeal must give the serial number or other identification of the case and may include a statement of reasons for the appeal, and any arguments the appellant wishes to make.

If the notice of appeal did not include a statement of the reasons for the appeal, the appellant must file such a statement with the Board within $\mathbf{3 0}$ days after the notice of appeal was filed. If a statement was filed at the time of the original filing, the appellant may file additional statements of reason, arguments, or briefs within the 30 day period after the filing of the appeal.

If appellant fails to file a statement of reason within the time allowed, the appeal will be subject to summary dismissal.

If the appeal is made to a decision of the Director, Minerals Management Service or of the Director of the Bureau of Land Management, the appellant will serve the Associate Solicitor, Division of Energy and Resources, Office of the Solicitor, U.S. Department of Interior, Washington, DC 20240. If the appeal is to a decision of another BLM office, the appellant shall serve the appropriate Regional or Field Solicitor (see Appendix 1A).

If the appeal is to a decision of an administrative law judge, the appellant shall serve the attomey from the Office of the Solicitor who represents the BLM or Minerals Management Service at the hearing, or in the absence of a hearing, who was served with a copy of the decision by the administrative law judge.

If any party served with a notice of appeal wishes to participate in the proceedings on appeal, he/she must file an answer within $\mathbf{3 0}$ days after service on his/her of the notice of appeal or statement of reasons where such statement was not included in the notice of appeal. If additional reasons, written arguments, or briefs are filed by the appellant, the adverse party has $\mathbf{3 0}$ days after service on him/her within which to answer them. The answer must state the reason why the answerer thinks the appeal is without merit and should not be sustained. Answers must be filed with the Board of Land Appeals, Office of Hearings and Appeals, Arlington, VA 22203 (see Appendix 1A).

Either party to an appeal may, if he/she desires a hearing to present evidence on an issue of fact, request that the case be assigned to an administrative law judge for such a hearing. A request must be made in writing and filed with the Board within 30 days after the answer is due and a copy of the request should be served on the opposing party in the case. The allowance of a request for hearing is within the discretion of the Board, and the Board may, on its own motion, refer any case to an administrative law judge for a hearing on an issue of fact. If a hearing is ordered, the Board will specify the issues upon which the hearing is to be held and under which general rules.

The administrative law judge may issue subpoenas directing the attendance of witnesses at hearings to be held before him or at the taking of depositions to be held for the taking of testimony but not for discovery. 
The administrative law judge may, at his discretion, on his own motion or motions of one of the parties or of the BLM direct the parties or their representative to appear at a specified time and place for a prehearing conference to consider:

1. the possibility of obtaining stipulations, admissions of facts, and agreements to the introduction of documents

2. the limitation of the number of expert witnesses

3. any other matters which may aid in the disposition of the proceedings

The administrative law judge must issue an order which recites the action taken at the conference and the agreements made which limit the issues for hearing to those not disposed of by admissions on agreements.

The administrative law judge must set a place and time for the hearing and notify all parties and the BLM. Postponements of hearings will not be allowed upon the request of any party or the BLM except upon a showing of good cause and proper diligence. Such a request must be filed a minimum of 10 days prior to the date of the hearing. The request for a postponement must state in detail the reasons why a postponement is necessary. Only one postponement will be allowed to a party on account of the absence of witnesses, unless the party requesting a further postponement shall, at the time, apply for an order to take the testimony of the alleged absent witness by deposition.

Upon completion of the hearings and the incorporation of the summary or transcript in the record, the administrative law judge will send the record and proposed findings of fact on the issues presented at the hearing to the Board. The proposed findings of fact will not be served upon the parties; however, the parties and the Bureau may, within 15 days after the completion of the transcript or the summary of the evidence, file with the Board such briefs or statements as they may wish respecting the facts developed at the hearings.

Although the Board of Land Appeals exercises the full authority of the Director of the Office of Hearing and Appeals and the Secretary of Interior, the Director or Secretary may assume jurisdiction of any case before the Board or review any decision of the Board of the Office, or direct reconsideration of any decision by any board of the Office.

Once a decision has been reached by the Board, no further appeal is allowed. Reconsideration of a decision may be granted only in extraordinary circumstances where, in the judgment of the Director or Board, there is sufficient reason. Requests for reconsideration must be filed promptly or within 60 days, and must state what particular error was made. The filing and pending of a request for reconsideration shall not in itself be reason to stay a decision unless such stay is ordered by the Director or Board. A decision on whether or not to request reconsideration does not, however, exhaust administrative remedies. 


\section{Special Protection for Units of the National Park System}

The Geothermal Steam Act of 1970 (P.L. 91-581) excluded lands within units of the National Park System from geothermal exploration and development. However, concern that geothermal exploration and development outside certain units of the National Park System could cause irreversible damage to significant thermal features within units of the National Park System caused Congress to pass Section 115 of P.L. 99-591. Section 115 amended the Geothermal Steam Act of 1970 by adding Section 28 to P.L. 91-581.

Section 28 required the Secretary of Interior to publish in the Federal Register within 120 days of enactment of P.L. 91-591, a proposed list of significant thermal features within a number of units of the National Park System. Among the units in the Pacific Northwest were Mount Rainier National Park and Olympic National Park. Crater Lake National Park was not included in the list due to insufficient information concerning any significant thermal feature that could exist on the lake floor. The Secretary did, however, prohibit leasing of federal lands surrounding Crater Lake until such time as a determination as to the existence of significant thermal features could be made.

In all, 22 units were proposed for special protection. The Secretary was requested to consider the following criteria in determining the significance of any thermal feature:

1. size, extent, and uniqueness

2. scientific and geologic significance

3. the extent to which such features remain in a natural, undisturbed condition; and

4. significance of thermal features to the authorized purposes for which the National Park System unit was created (Mohorich, 1988)

After a review of the proposed units by the Secretary, a final list was published on June 30, 1987. Of the original 22 units, 13 were determined to be of such natural significance that special protection was requested. In the Pacific Northwest, only Mt. Rainier National Park was included in the final list and given such protection. Prior to the passage of P.L. 99-591, special protection had been provided for Yellowstone National Park.

The statute provides that whenever a geothermal lease application is received or a decision is made to hold a competitive lease sale, the Secretary is to determine, based on scientific evidence, if exploration, development, or utilization of the geothermal resource would be reasonably likely to have a significant adverse affect on the thermal features. Such a determination is to be posted for public comment. If it is concluded that a significant adverse affect would result, then the lease is not to be issued and the lands are to be withdrawn from further leasing under provision of the Geothermal Steam Act of 1970.

For those lands where exploration, development, or utilization would cause an adverse, but not significant adverse, effect, the Secretary is to include special lease stipulations to protect the feature(s) including: 
1. requiring the lessee to reinject geothermal fluids into the rock formations from which they originated

2. requiring the lessee to report annually to the Secretary on his/her activities

3. requiring the lessee to continuously monitor geothermal production and injection wells

4. requiring the lessee to suspend activity, temporarily or permanently, on the lease if the Secretary determines that ongoing exploration, development, or utilization activities are having a significant adverse effect on significant thermal features

In addition to many activities required of the Secretary of Interior, the Act also requires the Secretary of Agriculture to consider the effects on significant thermal features on lands administered by that department when determining whether or not to consent to geothermal leasing (Mohorich, 1988).

In order to implement the provisions of Section 115, an Interagency Agreement affecting geothermal leasing was developed and entered into by the directors of the BLM, the National Park Service (NPS), the United States Geological Survey (USGS), and the Chief of the Forest Service (FS). The agreement became effective on December 9, 1987, and is intended to ensure compliance with the provision of the Act while at the same time ensuring timely action on lease applications or lease sales.

The process to implement the Interagency Agreement is a complex one as seen in the Gantt Chart in Figure 8. In as much as the process has yet to be fully tested, no estimate of the time required to complete the process can be made (Mohorich, 1991).

The terms of the Interagency Agreement provide for the NPS specifying those geographic areas within which they wish to review geothermal lease applications on a case-by-case basis. In all other situations, the BLM will complete a technical checklist and if no geologic or hydrologic connection with a significant thermal feature is established, the lease application would be subject to the preparation of an Environmental Impact Statement.

In Washington State, the case-by-case review process is in effect in Pierce, Yakima, and Lewis counties.

Because the Secretary has not made a final determination regarding the inclusion of Crater Lake National Park in the list of units requiring special protection, and because in the interim no lands "surrounding" the park are be offered for lease, a working agreement was reached between the Oregon State Office of the BLM and the Regional Office of the NPS. This includes: 




Figure 8: Interagency Agreement for Implementing
Section 115 of Public Law $99-591$ 
1. A leasing moratorium extending from a distance of 5 miles beyond the boundaries of Crater Lake National Park in the counties of Jackson, Klamath, and Douglas.

2. In all other parts of Jackson, Klamath, and Douglas counties a case-by-case review process is in effect.

\section{Leasing Requirements}

\section{Competitive Leasing}

The procedure for obtaining a federal geothermal lease depends upon the competitive interest classification of the land. Lands classified by the Secretary of Interior as being in KGRAs are leased on a competitive bid basis. All other available federal lands are available for non-competitive leasing.

The BLM state office manages leasing on federal lands classified as being in a KGRA. The appropriate surface management agency (i.e., BLM, Forest Service, or DOD) conducts the necessary pre-lease environmental review and determines which areas will be available for leasing. BLM sets the lease sale date and publishes public notices. On the day of the sale, each bidder must submit a sealed bid that includes payment for at least one-fifth of the bid amount. Leases generally are awarded to the highest bidder. BLM may request the bidder to submit a statement of qualifications either before or after bid acceptance. The federal govemment reserves the right to reject any and all bids.

Figure 9 illustrates the pre-lease activities of the federal regulatory process concerning competitive leasing on KGRA lands (Fujimoto, 1990).

Regulations governing KGRA status and access to federal lands are found in Title 43, Chapter 11 of the Code of Federal Regulations (43 CFR Part 3210, 3220).

\section{Noncompetitive Leasing}

Federal lands that have not been excluded from leasing or classified as being in a KGRA are available to the first qualified applicants on a noncompetitive basis. The procedure begins with filing an "Offer to Lease and Lease for Geothermal Resources." The offer requires: a site description; that an individual, corporation, or municipality is qualified to hold a lease; and other specified information. Each application must be filed with the BLM state office in a sealed envelope marked "Application for a Lease Pursuant to 43 CFR Part 3200" and accompanied by a $\$ 75$ filing fee plus the first year's advance rental at $\$ 1.00$ per acre or fraction thereof. Lease applications will be considered on the basis of priority by date of filing and contingent on an environmental review in place or to be conducted.

The pre-lease activities of the federal regulatory process for noncompetitive leasing are shown in Figure 10 (Fujimoto, 1990). 


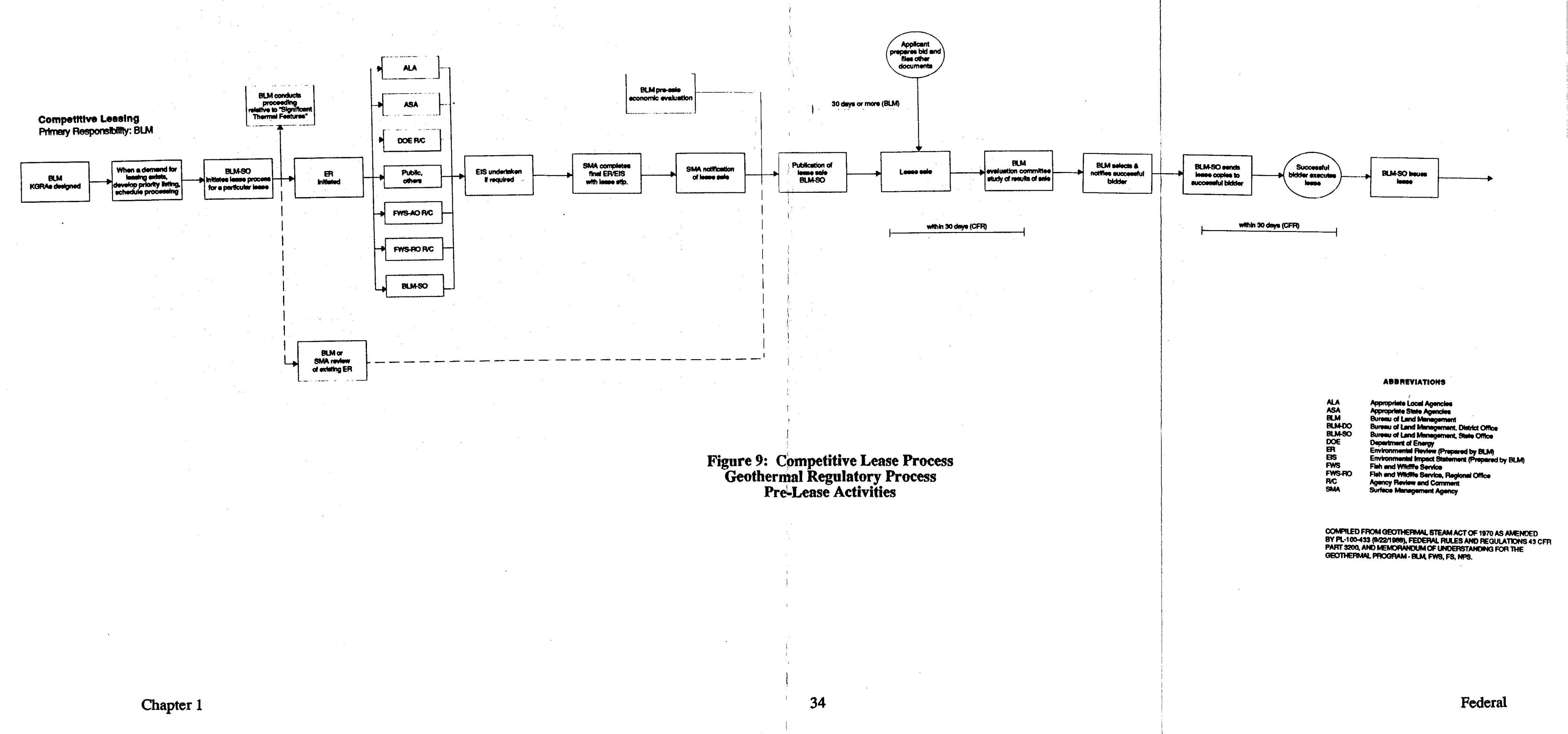




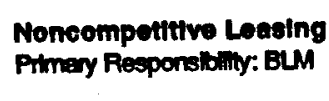


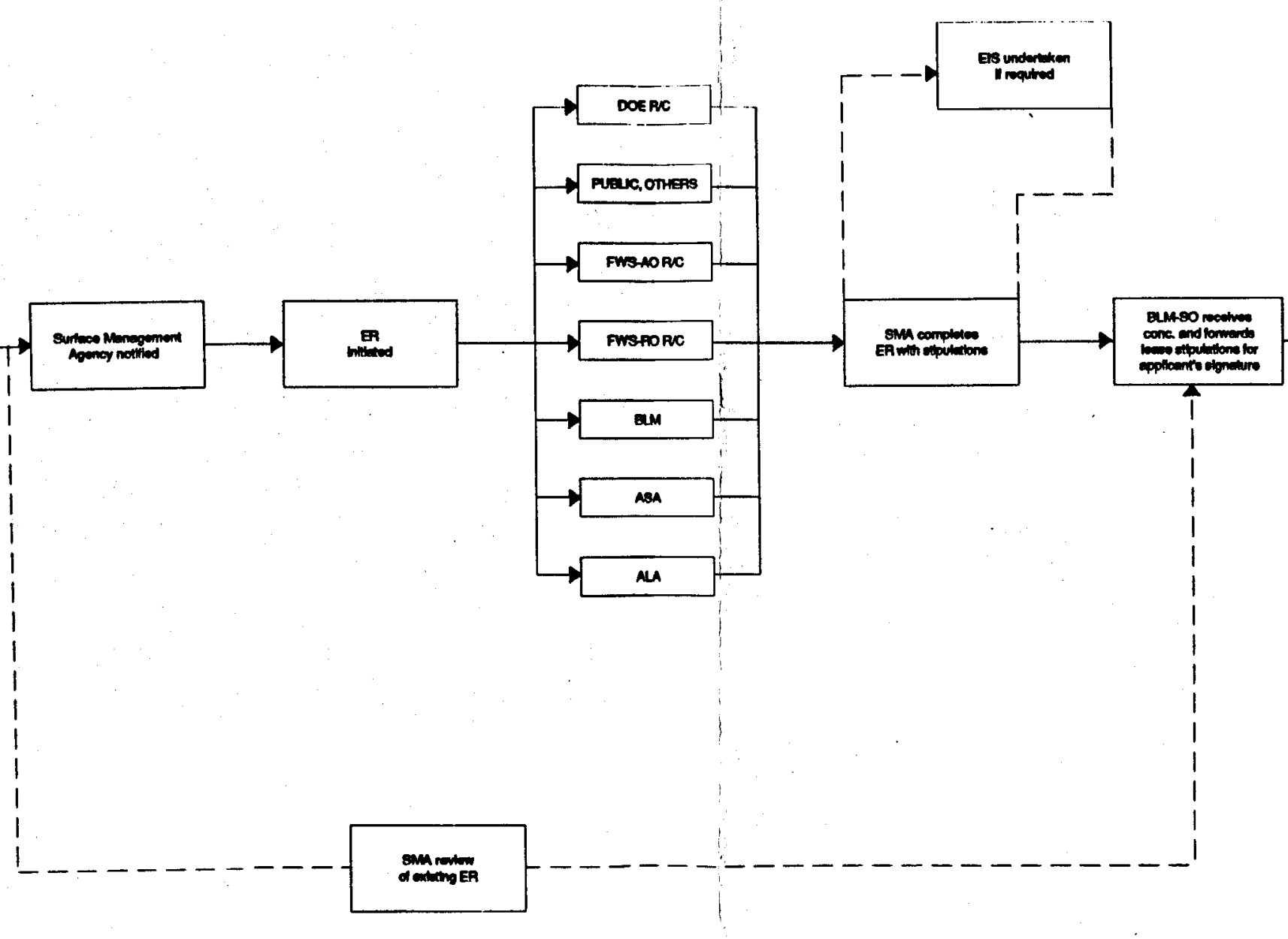

Figure 10: Noncompetitive Lease Process

Geothermal Regulatory Process

$$
\text { Pre-Lease Activities }
$$

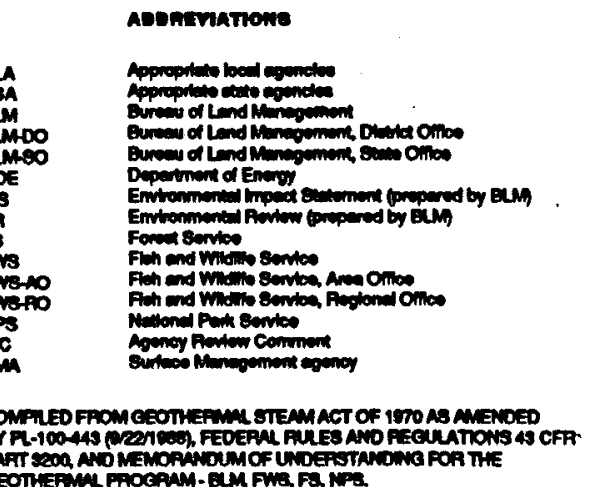


Salient features of the federal lease terms, covering both competitive and noncompetitive leases, include:

\section{Lease Limitations}

A geothermal lease cannot exceed 2,560 acres. The minimum area for a lease application is all available land within a section (approximately 640 acres) except at the discretion of the Secretary of Interior (43 CFR 3203.2).

The maximum total holdings within any one state is 51,200 acres (43 CFR 3201.2(a)).

- $\quad$ Primary Term

All federal leases are issued for a primary term of 10 years.

- Extension of Primary Term

A lease that is being "diligently" drilled before the end of the primary term will be extended for 5 years and for the duration of commercial production up to 35 years. This also applies to a lease committed to a cooperative plan, communization agreement, or a unit plan. However, the primary term can also be extended for two additional consecutive 5-year periods if the operator is making diligent efforts toward utilization and has drilled a well capable of producing commercial quantities of geothermal resource. In order to obtain such extensions, the operator will submit a request for lease extension to the authorized officer (BLM state office) at least 60 days prior to the end of the primary term of the lease or prior to the end of any period of extension already granted. The request must:

1. Include a report documenting that the operator has made bona fide efforts to produce or utilize geothermal resources in commercial quantities given the current economic conditions for marketing geothermal steam, including a description of:

(a) Operations conducted during the primary term of the lease and currently in progress to identify and define the geothermal resource including a summary of the results of those operations

(b) Actions then in support of operation including obtaining permits, conducting environmental studies, meeting permit requirements, etc.

(c) Current economic factors and conditions that affect the lessee's efforts to produce or utilize geothermal resources in commercial quantities

(d) Actions taken in the leases' primary term and currently in progress to negotiate marketing arrangements, drilling agreements, financing for electrical generation transmission projects, or other related actions 
2. Indicate whether the operator chooses to make payments in lieu of commercial quantities production or to make significant expenditure during the period of the extension.

(See P.L. 100.443 [30 U.S.C. 1005]) Section 6, Geothermal Act of 1970.

- Annual Rental Fee

The minimum rental payment (exact amount set in lease) is $\$ 1$ per acre and $\$ 2$ per acre for KGRA lands.

After the 5th year of the lease, in addition to the $\$ 1$ per acre rental, expenditures for exploration must be made in accordance with the following table unless commercial production is established.

\section{Table 2}

Lessee Exploration Expenditure Requirements

\begin{tabular}{c} 
Lease Yea \\
\hline 6 \\
7 \\
8 \\
9 \\
10
\end{tabular}

Expenditure

Per Acre(\$)

10-15

4
6
8
10

12

The lessee may exercise the option of paying an additional $\$ 3$ per acre rental in lieu of performing the minimum diligence requirements. Failing to meet these requirements by the end of a lease year will result in lease cancellation.

Exploration expenditures during the first 5 years, and all subsequent years, may be credited to the escalated portion of rent due.

To qualify as diligent exploration, the results of exploration and associated expenditures must be submitted for approval to the BLM authorized officer.

- Royalties

Royalty payments are made in lieu of rentals once commercial production occurs. They are:

- 10 percent minimum and 15 percent maximum of the value of geothermal production. The absolute minimum payment, however, is set at $\$ 2$ per acre

- 5 percent maximum of the value of any by-product produced

- 5 percent maximum on the value of commercially demineralized water 


\section{- Lease Renewal}

Leases may be continued for the extent of commercial production up to an additional 40 years. Leases may be renewed for a second 40 year term if commercial production continues and the acreage is not required for other use.

\section{Plans, Permits, Notices, Records, and Reports Required in Post-Lease Activities}

Once a lease has been issued by BLM, any persons desiring to conduct exploration, development, and utilization operations must file for approval with the authorized officer of the BLM before entering the lands. See Figure 11 for an idealized time line for project implementation at a representative Oregon site. Time lines for projects in other states could vary slightly depending on state rules and regulations. Post-lease activities are detailed in Figure 12 and Table 3 (page 46).

Orderly development of a geothermal resource involves several major phases. These phases must be covered in the Plan of Exploration, Plan of Baseline Data Collection, Plan of Development, Plan of Injection or Disposal, Plan of Utilization, and Plan for Production. Plans may be submitted separately or combined. A plan will also be required for any subsequent operations involving major surface disturbance in addition to that approved under a previous plan.

All post-lease exploration activities on federal lands are carried out under a Plan of Operation approved by BLM and with the concurrence of the surface management agency. Permit applications for all such post-lease exploration activities require the completion of an environmental review by the surface management agency before permit issuance (Feuer 1990).

Resource production on all federal lands is regulated through a Plan of Production approved by BLM. Before such a Plan of Production can be approved, the applicant may be required to collect environmental baseline data describing the existing environment for one year. No Plan of Production can be approved by the BLM until after completion of an environmental review, and such approval must have the concurrence of the surface management agency if other than the BLM. A finding of significant environmental impact during the review process will require the preparation of an Environmental Impact Statement (EIS) pursuant to the National Environmental Policy Act of 1969 (NEPA) before the plan may be approved. The EIS will be prepared by the BLM, and must be approved by all other responsible land management agencies (see Preparing Environmental Impact Statements). 
Exploratory Driming/tosting

\begin{tabular}{|c|c|c|c|c|c|c|c|c|c|c|c|c|c|c|c|c|c|c|c|c|c|c|c|}
\hline Mas hom Apola for To Hotes & -1.1 &  & $1=$ & -7 & $-1=$ & $7=1$ & $n=$ & T. 10 & 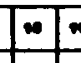 & .7 & $=10$ & $T=$ & -1 & -10 & -1 & $-F$ & $F$ & 7 & & I. & m. & & 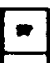 \\
\hline TO Holos (Several stios & & & & & & & & & & & & & & & & & & & & & & & \\
\hline BLMPOE, BUMUSFS EA & & 16 & & & & & & & & & & & & & & & & & & & & & \\
\hline BuDrteng Pempis & & & \% & & & & & & & & & & & & & & & & & & & & \\
\hline 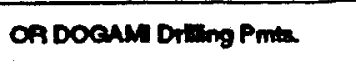 & & & $\%$ & & & & & & & & & & & & & & & & & & & & \\
\hline  & & & 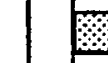 & : & & & & & & & & & & & & & & & & & & & \\
\hline  & & & & & 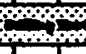 & 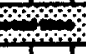 & & & & & & & & & & & & & & & & & \\
\hline
\end{tabular}

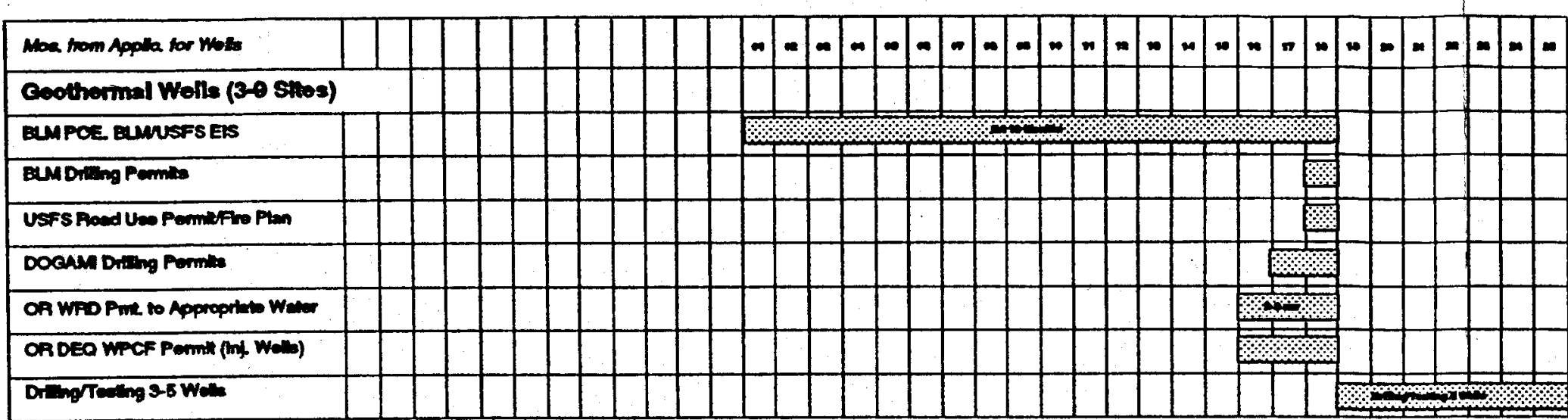

Power Plant Facillty, Production/njection Wells, Transmission Line

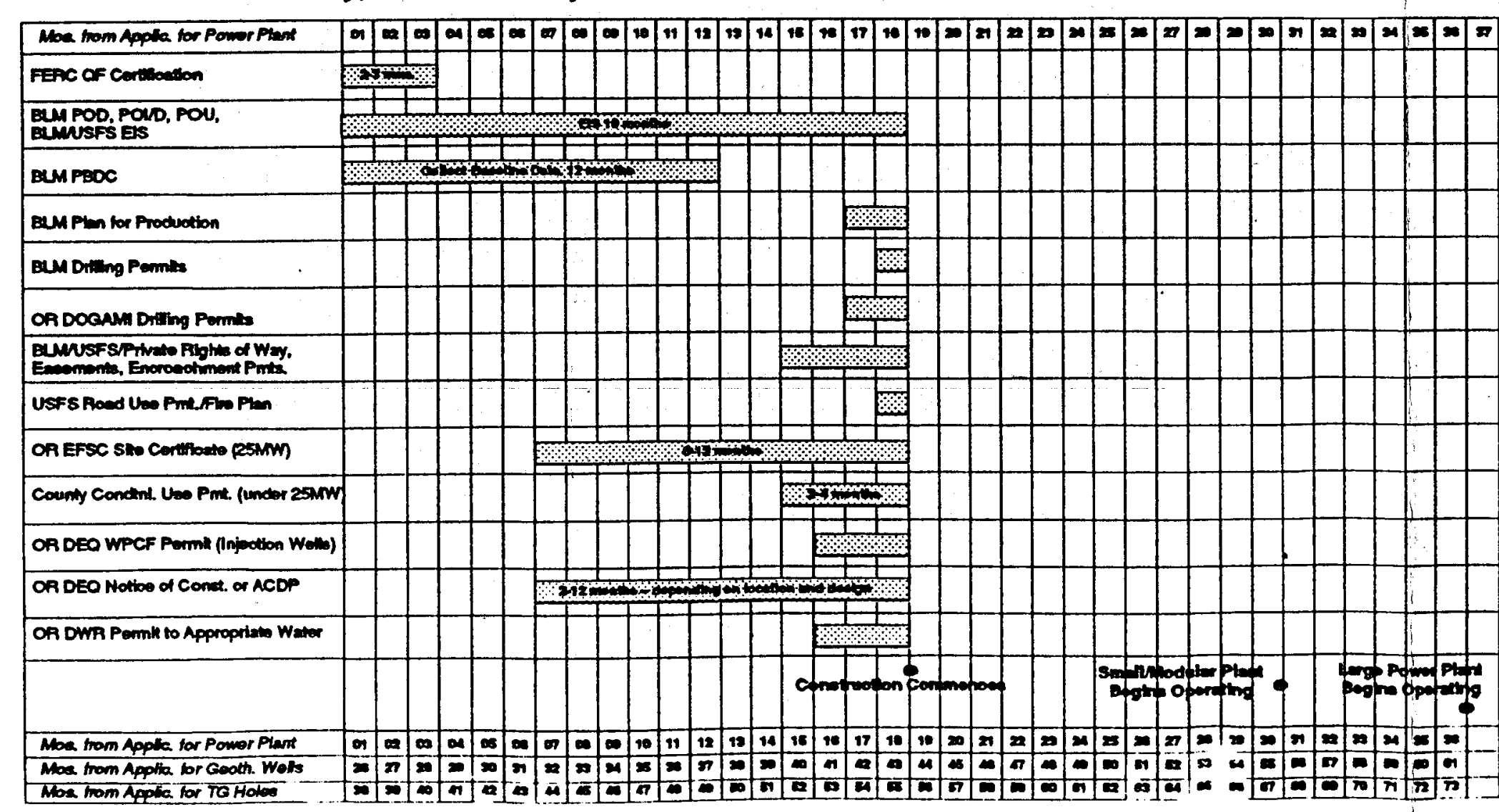

\section{Comments/Assumptions to Timeline}

Leases: Assumes that leases have been lssued prior to drilling of geothermal wells.

Appeals: Assumes that no permits will be appoeted.

TG Holes: Temperature Gradient holes in the Cascades are lkely to be several thousand for deep. For this timeling it is assumed that five deep holes could be drilled with hundred feet deep) TG holes are effectlve and many more could be drithed in 6 months.

In the Cascades, weather/snow can restrict access for TG drilling to warmer months. The deal stivation would be to dril TG holes one year and exploraton wells the next.

Geoth. Wells: Assumes that the Tempereture Gradient (TG Hole) driling encourages the drilling of exploratory wells.

Assumes three to five exploratory wells might be ctilled (only two or three if they come up "dry"), requiling 3-9 alternate dril sties. If the first well is dry, another stie

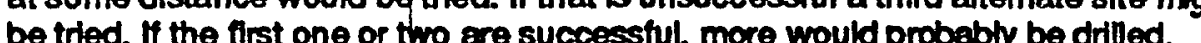
Assumes that if three wells are drilled, there is one ing operating and if five are drilled, two itgs are operatipg.

Assumes that there is a sufficient market for eloctrichy to justily the ilsk financing of exploration drilling.

Power Plamt: Assumes a power sales contract is in place to support financing of power plant.

Abbrevlated Terms

ACDP Air Contaminant Discharge Permit issued by OR DEO

BLM U.S. Department of the Interior, Bureau of Land Managememt

EA Environmental Assessment under NEPA

EIS Envionmental Impact Statement under NEPA

FERC Federal Energy Regulatory Commission

NEPA National Environmental Policy Act

OR DEQ Oregon Department of Environmental Qually

OR EFSC Oregon Energy Facillty Stting Council

OR DOGAMI Oregon Department of Geology and Mineral Industrles

OR WRD Oregon Water Resources Depertment

PBDC Plan for Basellne Data Collection

POE Plan of Explonation

POD Plan of Development

POVD Plan of Injection or Disposal

POU Plan of Utillzation

PFP Plan for Production

PURPA Publlc Utillities Regulatory Polky Act

QF Quallying Facllty (Certfication by FERC under PURPA)

TG Holes Temperature Gradient Holes

USFS U.S. Forest Service

WPCF OR DEQ Water Pollution Control Facility Permit for Injection Wells 


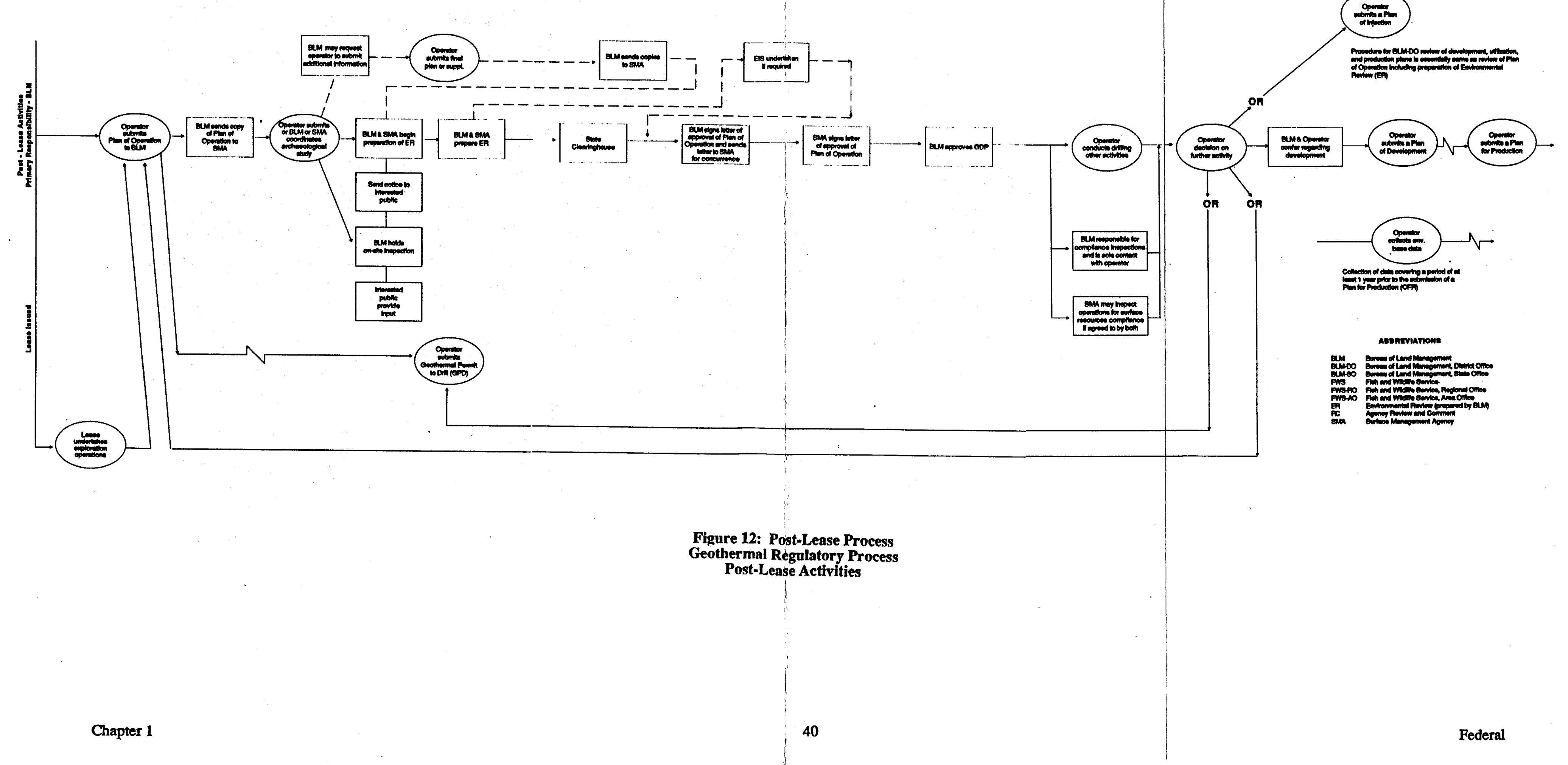


BLM, as the lead agency for facility siting on federal lands, coordinates the processing of all applications to construct energy conversion facilities on federal lands. The responsible surface management agency regulates construction of related transmission lines on federal lands. The construction of geothermal energy conversion facilities is regulated under the provisions of 43 CFR Part 3250 and 3260. In addition, all permits to construct conversion facilities and/or transmission lines must have the concurrence of the appropriate surface management agency. On state and private lands this responsibility often resides with an Energy Facility Siting Council (EFSC). State energy facility siting authority over state lands may extend to siting energy facilities on federal lands, as has been claimed by the Oregon EFSC. However, the state may only exercise authority over the construction of energy conversion or transmission facilities on federal lands after necessary federal permits have been approved.

\section{Surface Management Agency}

The surface management agency (SMA) (United States Forest Service, Department of Defense, etc.) if other than the BLM is responsible for the following activities:

- preparing environmental reviews on suitability of National Forest lands or land managed by that agency for geothermal leasing purposes

- providing input to BLM on surface considerations for post-lease environmental evaluations

- preparing lease stipulations governing surface management

- supervising land uses on leased land outside areas of operation

- issuing special use or prospecting permits for surface use or occupancy

\section{Geothermal Resource Operations (GRO) Order}

Federal requirements for exploration, development, and utilization of geothermal resources, as issued under the Geothermal Steam Act of 1970, are discussed in detail in the Geothermal Resources Operations (GRO) Orders, which were originally published by the Geological Survey. The GRO Orders have been or are being updated by the BLM to reflect internal shifts in federal agency responsibility. The items covered by the GRO Orders, however, remain the same despite the shifts in responsibility:

$\begin{array}{ll}\text { GRO Order 1 } & \text { Exploratory Operations } \\ \text { GRO Order 2 } & \text { Drilling, Completion, and Spacing of Geothermal Wells } \\ \text { GRO Order 3 } & \text { Plugging and Abandonment of Wells } \\ \text { GRO Order 4 } & \text { General Environmental Protection Requirements } \\ \text { GRO Order 5* } & \text { Plans of Operation, Permits, Reports, Records, and Forms } \\ \text { GRO Order 6 } & \text { Pipelines and Surface Production Facilities } \\ \text { GRO Order 7 } & \text { Production and Royalty Measurement, Equipment, and Testing } \\ & \text { Procedures }\end{array}$

*Draft but still used as guidelines. 
The post-lease activities of the federal process are shown in Figure 12, page 40 (Fujimoto, 1985).

The following plans, permits, notices, records, and reports are required for post-lease exploration, development, and utilization operations:

\section{Exploration}

- Designation of Operator - Identifies the operator and local agent with full authority to act on behalf of lessee.

- Plan of Operations (POO) - Specifies information applicable to all required plans of operation except for the Plan of Baseline Data Collection. Plans may be submitted combined or separately (see Exhibit 1).

- Notice of Intent to Conduct Resource Exploration Operations (Form 3200-9) - Pertains to exploration activities such as geophysical surveys and gradient well drilling.

- Plan of Exploration (POE) - Pertains to exploration drilling that involves major surface disturbances.

- Geothermal Exploration Permit (Form 3260-1) - Required for any exploration operations such as geophysical surveys and drilling of temperature gradient holes to 610 meters $(2,000$ feet).

- Geothermal Drilling Permit (Form 3260-2) - Required for deeper drilling 610+ meters $(2,000 \mathrm{ft} .+)$ to determine the presence of, test, develop, produce, or inject the geothermal resource.

- Geothermal Sundry Notice (Form 3260-3) - Pertains to certain miscellaneous activities such as drill site preparation, subsequent well operations, or construction activities.

- Monthly Report of Geothermal Operations (Form 3260-5) - Report covering all lease activities (exploration, drilling, injection, production, etc.) starting with the month in which operations begin under an exploration or drilling permit.

- Notice of Completion of Exploration Operations (Form 3200-10) - Pertains to completion of exploration operations submitted under Form 3200-9, Notice of Intent and Permit to Conduct Exploration Operations.

- Completion of Exploration Operations - A completion report must be submitted for exploration operations permitted under Form 3260-1, Geothermal Exploration Permit.

- Geothermal.Well Completion Report (Form 3260-4) - Pertains to details of drilling, cementing, formation, and production tests, etc. Also, any geophysical, geochemical, or temperature surveys performed in the well. 
- Annual Report of Expenditures for Diligent Exploration Operations - Applicable only if a diligent exploration credit is desired for subsequent years of exploration on a lease.

- Oil and Gas or Geothermal Lease Bond (Form 3000-4) - Required for all field operations, pre- and post-lease.

\section{Development}

- Plan of Development (POD) - Pertains to drilling and construction (excluding utilization facility construction) that is necessary to initiate commercial production. A POD may be combined with a Plan of Injection or Disposal (POI) and/or the Plan of Utilization (POU), to expedite processing.

- Geothermal Drilling Permit (Form 3260-2) - See Exploration.

- Daily Drilling Report and Record - See other records.

- Well Logs and Surveys - See other records.

- Geothermal Sundry Notice (Form 3260-3) - See Exploration.

- Geothermal Well Completion Report (Form 3260-4) - See Exploration.

- Plan of Baseline Data Collection (PBDC) - The lessee must collect environmental data for a period of at least 1 year before a Plan for Production (PFP) can be submitted. To ensure acceptability of data gathered, it is recommended that a PBDC, if required, be submitted soon after a potentially produceable resource is identified.

- Plan of Injection or Disposal (POI) - Pertains to the injection and disposal of geothermal effluent and associated by-products.

- Monthly Report of Geothermal Operations (Form 3260-5) - See Exploration 43 CFR 3264.

- Environmental Quarterly Report - Pertains to environmental data collected during development and subsequent operating activities (required by the authorized officer of the BLM).

\section{Utilization}

- Plan of Utilization (POU) - A POU should present a general overview of the proposed facility and its operation, and must be submitted prior to construction of either an electric or direct use utilization facility.

- Geothermal Utilization Permit (Form 9-1968) - A two-step approval is required. The first approval authorizes construction and pre-start-up testing. The second approval authorizes commercial operation of the facility. 
- Geothermal Sundry Permit (Form 3260-3) - See Exploration.

- Baseline Data Report - Pertains to environmental data collected as covered in the PBDC. This report must be submitted prior to the Plan for Production (PFP) and before commercial production begins.

- Plan for Production (PFP) - The PFP covers production procedures, monitoring, and any operations to be conducted after completion of drilling, construction, and installation of all wells and facilities needed to commence commercial production.

- Registration as a Small Power Producer (FERC) - A geothermal facility that is producing electricity may be certified by FERC. Two alternative processes of certification are available. The developer may be self-qualified by notifying FERC of the existence of the facility and supplying them with certain information. Although this method requires less paperwork and can be completed within a shorter time than the other, it has certain disad-vantages that may cause delay and other problems later. The alternative is to apply to the Commission for certification. Application requires detailed information of the facility and a filing fee.

- Employer Identification Number (IRS) - For tax purposes, any employer must file with the local IRS office and obtain an employee's tax number.

- Compliance with OSHA Standards (OSHA) - Industrial safety standards are applied to any employer of one or more persons. No registration or permit is required, but compliance with all rules is required, and inspection may be conducted at any time. Businesses with more than 11 employees must post an information poster regarding the necessity to comply with OSHA standards, and must file a summary of all occupational illnesses and accidents.

- Monthly Report of Facility Operations (43 CFR 3264.2-5).

- Monthly Report of Geothermal Operations (Form 3260-5) - See Exploration.

- Monthly Report of Sales and Royalties (Form MMS-2014) - Beginning with the month in which production first is sold or utilized, the lessee must file a monthly report of sales and royalties.

- Environmental Quarterly Report (If required) - See Development.

\section{Other Reports}

- Geothermal Pollution Incident Report (Form 9-1961) - Must be submitted within 30 days of any blowout, spill, leak, toxic or noncondensible gaseous emissions, or other incident that may have a significant impact on the environment. 
- Geothermal Accident and Injury Report (Form 9-1962) - All accidents and injuries must be reported to the authorized officer within 24 hours of the occurrence. A written report must be filed no later than 15 days after the incident.

\title{
Other Records
}

- Servicing Records - Must be available at the work site. Pertains to cementing, stimulation, perforation, acidizing, and formation fracturing reports, casing, drill pipe, and other downhole component measurement.

- Safety Records - Records of safety meetings, safety devices installed at the work site, and work crew drills on contingency plan procedures must be available at the work site.

- Company Records - Copies of all geologic, geophysical, stratigraphic, structural, engineering, and environmental studies, reports, and records must be made available upon request of the authorized officer.

- Daily Drilling Report and Record - A permanent drilling record must be available at the work site.

- Well Logs and Surveys - After completion of operations, field prints or working copies of all downhole logs, temperature and fluid surveys, and mud logging results must be submitted to the authorized officer.

Table 3 shows which applications are needed for various geothermal activities and approximate time for processing.

\section{Additional Federal Permitting and Licensing Requirements}

\author{
Permit or Regulation: Prevention of Significant Deterioration (PSD) \\ Statutory Authority: 40 CFR 52.21 \\ Agency: Environmental Protection Agency (EPA)
}

The basic objective of the Prevention of Significant Deterioration (PSD) program is to prevent substantial degradation of air quality in areas that are in compliance with national ambient air quality standards, while maintaining a margin for future industrial growth. Each proposed new or modified air contaminant source must undergo a new source review. As part of this review, PSD applicability is determined. If PSD review is required, a PSD application must be submitted and a permit obtained before beginning project construction. 


\section{Applications and Representatives Processing Times for Various Geothermal Activities FEDERAL}

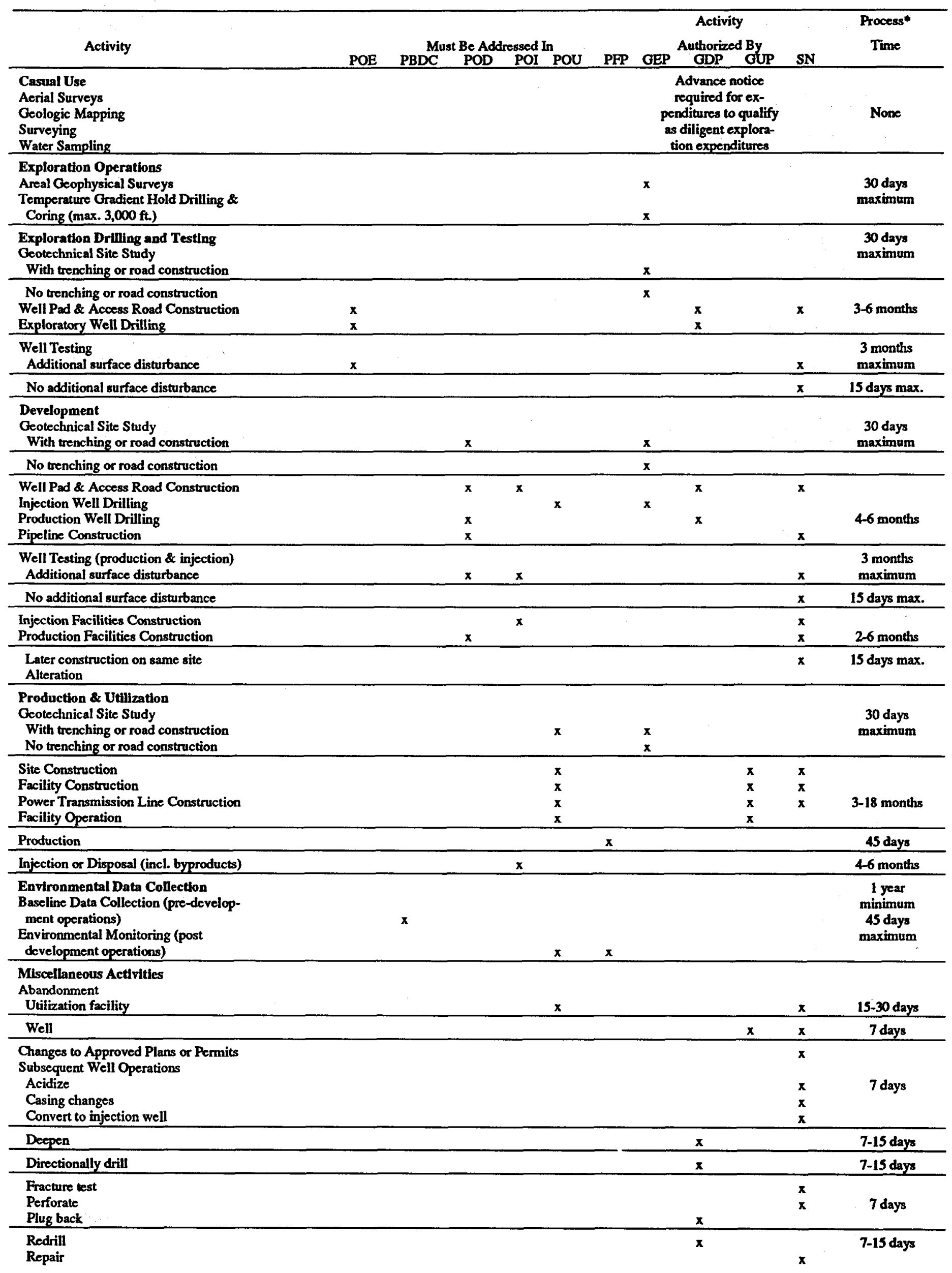


Table 3 (continued)

KEY POE $=$ Plan of Exploration; PBDC $=$ Plan of Baseline Data Collection; POD = Plan of Development; POU = Plan of Utilization, PFP = Plan for Production; GEP = Geothermal Exploration Permit;

GDP = Geothermal Drilling Permit; GUP = Ceothermal Utilization Permit; SN = Geothermal Sundry Notice.

Note: Where more than one Plan or Permit is checked off, the activity may be addressed in either Plan and authorized by either Permit.

Many of the itemized activities are processed together under one Plan rather than individually. Processing times shown are those for the entire Plan, and are based on submittal of a complete application. Processing of the Plans of Development, Injection or Disposal, and Utilization may be done concurrently, and submittal of these Plans wogether is encouraged.

* Time frames subject to NEPA compliance if required. Time frames may be extended if NEPA compliance/appeals/protests require such extensions.

Criteria that trigger PSD vary depending on the type and amount of air contaminant(s) emitted, type of facility, and the proximity of a project to a designated Class I area. Generally, PSD review is not required for facilities that emit less than 100 tons per year of a regulated pollutant.

Specific information on PSD requirements can be found in the Code of Federal Regulations (CFR) 40 CFR 52.21, as adopted and supplemented by state statute. However, this regulation is quite complex, so it is best to contact the appropriate air authority to determine if your proposal will require PSD review.

Permit or Regulation: National Pollutant Discharge Elimination System (NPDES) or 402 Permit Agency: Environmental Protection Agency (EPA)

A NPDES permit is required where a waste water source is discharged to "waters of the United States." If a geothermal project affects the quality of water in any way by adding sediments, decreasing oxygen content, or increasing temperature, this may be construed as discharging a pollutant and requires a National Pollution Discharge Elimination System (NPDES or 402) permit. For more information, contact the EPA office listed in Appendix $1 \mathrm{~A}$.

The application requires information on waste source flow and expected characteristics, disposal method, water supply, waste water disposal, water supply volumes, water utilization; planned improvements, storm water treatment, plant operation, materials and chemicals used, and production. Prior SEPA compliance is required.

\section{Permit or Regulation: Federal Water Pollution Control Act Agency. Environmental Protection Agency (EPA)}

Section 301 A "point source" of pollutants cannot discharge into navigable water without a National Pollution Discharge Elimination permit. A "point source" is a discernible, confined, discrete source. An industry or sewer outfall is a point source. An eroding hillside generally is not a point source. Discharges from normal farming, silvaculture, and aquaculture practices do not need permits. 
Section 303 This section authorizes states to adopt water quality standards. State standards are to consider the value of water for public drinking supplies, propagation of fish and wildlife, and recreation, among other uses. Each standard considers the respective uses and value of the water and includes criteria based on those uses.

Section 401 An applicant for a federal license or permit for an action that "may result in any discharge" into navigable waters must comply with federal and state water quality standards. Applicants must obtain a certificate that all discharges will comply with the standards.

Section 401 requires a certificate for any discharge. It applies even when a water user does not add anything to discharged water. For instance, a dam or diversion adds nothing to the water. But, it may diminish flow needed to dilute downstream wastes. It may also change naturallyoccurring temperatures and dissolved oxygen level. If a state rule on one of these water quality parameters is violated, a certificate of compliance will be denied.

Section 401(b) also requires that discharges comply "with any other appropriate requirement of state law." Section 401(d) has been construed to require federal permits and licenses be granted subject to any appropriate requirement of state law.

\section{Permit or Regulation: Noise Control Act and Executive Order 12088} Agency: Environmental Protection Agency (EPA)

This Act contains standards with which federal actions are encouraged to comply. It does not require approval of a noise permit. The Executive Order required federal actions to comply with state and local noise regulations where they exist.

\section{Permit or Regulation: Federal Procedures for the Protection of Prehistoric and Historic and Cultural Properties}

Statutory Authority: Section 106, National Historic Preservation Act 1966;

National Environmental Protection Act of 1969; 36 CFR 800

\section{Agency: Office of Archaeology and Historic Preservation}

All federal agencies are required by law to take into account the effect of their activities or archaeological and historic properties. Federal agencies have developed different procedures for evaluating the effects of their projects. Federal agencies are required to contact the state Historic Preservation Office to obtain the state's comments on the significance of a historic property and on the effect of a project on the property.

Step 1: Identify and evaluate historic properties. First, the federal agency reviews all of the available information that could help in determining whether there may be historic properties in the area of the proposed activity. Based on this review, the agency decides whether any additional survey work is needed to locate possible historic properties. 
Next, the agency identifies all National Register properties that might be affected by the proposed activity. The agency also identifies properties not actually listed in the Register, but which appear to meet eligibility criteria. Then the agency and the State Historic Preservation Office (SHPO) together apply the National Register criteria to decide whether the properties are eligible for listing, and thus subject to the Section 106 process.

Step 2: Assess effects. Once historic properties have been identified and found to meet National Register criteria, the federal agency determines whether its proposed activity will affect them in any way. Again, the agency works with the SHPO, making judgments based on criteria found in the Advisory Council's regulations. There are three possible findings:

No effect: If there will be no effect of any kind on the historic properties, the agency notifies the SHPO and interested parties of its determination of no effect. If the SHPO does not object, the agency proceeds with the project.

No adverse effect: If there could be an effect, but the effect would not be harmful to the historic properties, the agency obtains SHPO concurrence and submits to the Council a determination of no adverse effect. Or, the agency can submit its determination of no adverse effect directly to the Council for review and notify the SHPO of its determination. Unless the Council objects, the agency proceeds with its project or activity.

Adverse effect: If there could be a harmful effect to a historic property, the agency begins the consultation process.

Step 3: Consultation. During this step, an effort is made to find acceptable ways to reduce the harm ("avoid or mitigate the adverse effect") to the historic properties. The consulting parties are the agency and the SHPO; Council involvement in consultation is optional. Other interested parties (such as a local government, Indian tribe, or federal applicant for a grant, license, or permit) may also be invited to join the consultation, and must be invited under certain circumstances.

The agency gathers the necessary documentation, informs the public that consultation is underway, and works with the consulting parties to find a solution. When the consulting parties have agreed on steps to avoid or reduce harm to historic properties, they sign a Memorandum of Agreement (MOA).

In a very few cases, the consulting parties cannot agree on a solution, in which case the consultation is terminated. The agency may then submit documentation to the Council and request the issuance of written Council comments.

Step 4: Council Comment. Unless the Council has already signed the MOA (by virtue of being a consulting party), the agency submits the signed MOA to the Council for review. The Council can accept the MOA, request changes to it, or opt to issue written comments on the proposed activity. 
If the consulting parties have terminated consultation, the Council issues written comments about the proposed agency action directly to the head of that agency.

Step 5: Proceed. If the Section 106 review process has resulted in a Council-accepted Memorandum of Agreement, the agency proceeds with its proposed activity according to the terms of that MOA. Absent an MOA, the agency must take into account the Council's written comments, after which the agency makes the final decision about how (or whether) to proceed with its proposed activity. The agency notifies the Council of its decision.

Either outcome concludes the Section 106 review process and satisfies the agency's statutory responsibilities under Section 106 of the National Historic Preservation Act of 1966.

\section{Permit or Regulation: Federal Aviation Regulations, Part 77} Agency: Federal Aviation Administration

Federal Aviation Regulations, Part 77, apply to any structures more than 200 feet in height or other structure which may affect the safety of air navigation routes. These regulations require lighting and marking of potential hazards. The FAA may declare a structure a hazard to air navigation. Such a declaration makes it practically impossible to develop the structure because it cannot be insured against a collision with aircraft. Also, some states have parallel but more strict regulations.

\section{Permit or Regulation: Remote Radio Operations}

Agency: Federal Communications Commission (FCC)

Geothermal projects utilizing remote radio operation require a FCC permit. For more information, contact the FCC office listed in Appendix 1A.

\section{Permit or Regulation: Determination of No Hazard Agency: Federal Aviation Administration (FAA)}

Determination of No Hazard is required for the FAA. The FAA has forms that must be completed and reviewed to determine if any project feature (e.g., transmission towers) constitutes a hazard to aviation. A project layout showing elevation contours should be turned in with the application, and information on microwave towers and existing airports in the project area may be required. For more information, contact the FAA office listed in Appendix 1A.

\section{Approximate Time Required to Obtain Permit}

Approval of this permit requires approximately 2 months. 
Permit or Regulation: Notice of Proposed Construction or Alteration Agency: Federal Aviation Administration (FAA)

Any structure more than 200 feet above ground level, and any structure of greater height than defined surfaces extending outward and upward from airports must be registered as proper lighting and marking may be required. For more information, contact the FAA office listed ir Appendix $1 \mathrm{~A}$.

\section{Permit or Regulation: Park Service Approvals Agency: National Park Service}

If any part of a geothermal project is located near a unit of the National Park System, a "designated" or "study" river in the National Wild and Scenic Rivers System, a river listed on the Nationwide Rivers inventory, or a river listed in the 5(a) Rivers Inventory, contact must be made with the National Park Service. Each of the above categories has differing requirements regarding the location of projects. If it is unclear.whether any of these designated areas are affected by a particular site, a list may be obtained from the National Park Service. Reports on historic and archaeological resources and on recreational resources as required by Exhibit $\mathrm{E}$ of the license application should be prepared in consultation with the National Park Service for all projects. For more information, contact the National Park Service Regional Office listed in Appendix 1A.

\section{Indian Lands}

\section{Underlying Rights and Principles}

In exchange for giving the United States title to most of their land, the Indians retained reservations for homelands as well as a right to continue hunting and fishing at their usual and accustomed places, both on and off the reservation.

All Indian treaties were negotiated, executed, and ratified by Congress. Supreme Court rulings concerning Indian treaties have established several basic principals. Most fundamentally, the rights retained by the tribes are reserved rights, that is they are rights retained by the tribes at the time of treaty-making, and not given to them by the United States.

Each tribe that signed a treaty has a property right to the use of the resources in question. As a property right retained from before statehood, treaty rights are in the nature of easements on other real property interests.

Treaty rights have also been found by the federal courts to include an environmental right. For example, court decisions have forbidden actions that would inundate usual and accustomed fishing sites, dewater fish habitat, or degrade water quality to the detriment of the fishery. 
Finally, and perhaps most significantly, the tribes as governmental entities have a right to manage their resources. This means that the tribes undertake all activities necessary to adequately manage any and all resources, including protecting the environment necessary to sustain the resource.

Tribally or individually owned Indian Trust or restricted lands within or without the boundaries of Indian reservation may not be leased under provisions of the Geothermal Steam Act of 1970 (43 CFR Subpart 3201.1-6).

Individual Indian land (allotments) held in trust by the U.S., or tribal land held in trust by the U.S. can be permitted or leased for mineral development under authority of a March 3, 1909 act, Leases of Allotted Lands for Mining Purposes, or a May 11, 1938 act, Leases of Unallotted Lands for Mining Purposes, Duration of Leases, and the 1982 Indian Mineral Development Act. These acts are regulated by 25 CFR 211,212, and 216, and by 43 CFR 3100 through 3590 . The Bureau of Indian Affairs (BIA) is responsible for exploration permit and lease approval and administration. The BIA is responsible for operational supervision of prospecting and development.

Access to Indian land for non-disturbing surface exploration requires written agreement between operators and Indian land owners. Surface disturbing activities, including prospecting and development, require approval by BIA and BLM. The point of first contact should be between the prospective operators and tribal governments.

\section{Indian Cultural and Archaeological Concerns}

Indian groups and individuals have a strong cultural interest in preserving archaeological resources that may be adversely affected by development. Indians have lived in the Northwest for thousands of years. It is believed that many archaeological resources have not yet been discovered or have not been adequately researched by trained professionals. The tribes are becoming increasingly active in protection and interpretation of archaeological resources.

A number of laws are designed to protect archaeological resources. The National Historic Preservation Act requires consultations with the State Historical Preservation Office. The Archaeological Resources Protection Act protects sites on federal and Indian lands. State laws govern non-federal sites and removal of human remains.

These laws require that the developer determine what, if any, resources are present in the project area. The BLM and the U.S. Forest Service routinely include in their permit and licensing orders a requirement that the developer consult with the State Historic Preservation Officer (SHPO) to determine what resources are present. In most cases, the SHPO requires the developer to conduct surveys to accomplish this objective. 
In recent years, as tribes have become better organized to protect their interests, the BLM and Forest Service have also required that developers consult with the tribes. If the SHPO determines that there is a probability of resources being present, it would certainly be in the developer's best interest to seek out the local Indian tribes to determine their interests.

Areas of high geothermal potential may also be places of high religious significance to various Indian and other native American groups and are protected through provisions of the American Indian Religious Freedom Act (Public Law No. 95-341). If development is contemplated on federal or state lands, appropriate land management agencies should be contacted concerning the existence of American Indian Religious Freedom Sites. If such sites exist in the immediate vicinity of the proposed work, representatives of the Indian or other native American people should be contacted so that location of such sites can be determined and significance and usage patterms established.

The use of such sites is guaranteed to the Indians by statutes and only through closely working with the Indians can conflict be avoided or minimized. (A list of the federally recognized tribes in the region is found in Appendix 1F.)

Federal Regulatory Acts Protecting Indian Cultural and Archaeological Sites

National Historic Preservation Act, 16 U.S.C., Section 470.

Archaeological Resources Protection Act, 16 U.S.C., Section 470.

American Indian Religious Freedoms Act, 42 U.S.C., 1996.

\section{Power Sales}

The culmination of any successful resource development project is the sale of thermal energy or electrical output. A number of federal and regional agencies have played an important role in the establishment of the framework within which power sales are negotiated and entered into, including price structure and utility interconnection. Much of the legal framework was established in 1979 with the passage of the Public Utilities Regulatory Policies Act, P.L. 95-617, which provided developers of renewable energy projects with an opportunity to market electricity directly to utilities without fear of public utility regulation.

At the federal level the Federal Energy Regulatory Commission (FERC) plays the dominant role while regionally the Northwest Power Planning Council (NPPC) and the Bonneville Power Administration (BPA) are the principal players. Each of the states has also enacted legislation or administratively addressed the needs of non-utility developers of generation projects.

\section{Federal Energy Regulatory Commission}

The Federal Energy Regulatory Commission (FERC) is the most important federal agency relating to Qualifying Facilities (QFs) and the Public Utilities Regulatory Act (PURPA). Because in most states the electric grid and gas pipelines extend over state lines, the FERC has primary jur- 
isdiction over a state's utilities. Nonregulated utilities, i.e., those not state-regulated, and federal power marketing agencies are regulated by FERC. Also, FERC regulates all whole-sale transactions between utilities, federal power marketers, and QFs. Transactions between direct service industries and federal power marketers are FERC-regulated. In the case of PURPA, the states are required to implement the FERC rules for state-regulated utilities (Bain, 1989).

Aside from issuing PURPA rules (see PURPA Overview), FERC has a major role in several areas that affect QFs.

Of primary importance to developers is the QF certification process. Although FERC has rules for QF self-certification, many QFs seek FERC certification. Persons financing QFs often want to remove any uncertainty about qualifying status. However, seeking FERC certification opens a public comment period during which project opponents have standing to submit objections. FERC certification also is expensive. Recently, the certification process has been used by some developers to get qualifying status for their facility including miles of dedicated transmission lines. Such lines can extend the rights and obligations granted QFs by PURPA into other utilities' service territories. FERC is also playing a major role in expanding the market place for non-utility wholesale generation and addressing problems associated with transmission access and wheeling.

\section{Public Utilities Regulatory Act (PURPA) Overview}

\section{Background}

Congress enacted the Public Utilities Regulatory Policies Act (PURPA), P.L. 95-617, on November 9, 1978, as one of five component bills to the National Energy Act of 1978. PURPA was designed to lessen the country's dependence on foreign oil by requiring state utility commissions to consider rate structures that conserve energy and by encouraging the development of energy efficiency, cogeneration, biomass-fired power plants, and renewable generating resources. Renewable resources include solar, wind, hydropower, and geothermal generating facilities.

PURPA amended the Federal Power Act to reduce or eliminate obstacles to the development of cogeneration and small power projects. In effect, PURPA requires utilities to interconnect with qualifying cogenerators and small power producers (QFs) located in their service territories, to purchase power at a price based on the utility's full avoided cost for energy and capacity, and to provide non-discriminatory rates for back-up services. PURPA also exempts small power producers from portions of the Federal Power Act, 16 USC 791a-828c (1981), the Public Utility Holding Company Act of 1935, 15 USC 79b(a)(3), and certain state utility regulations. PURPA does not, however, require a utility to interconnect with and purchase power from independent producers located outside of its service territory.

Of particular importance to independent power producers are the provisions of PURPA dealing with small power production. Specifically, under Title II Sections 201 and 210, the Federal 
Energy Regulatory Commission (FERC) amended its regulations to deal with such critical issues as size, ownership, and efficiency criteria for qualifying small power production and cogeneration facilities; electric utility obligations; rates for purchase and sales; interconnection cost reimbursements; and state implementation requirements regarding PURPA. (These changes are located in Title 18 of the Code of Federal Regulations, Chapter I, Part 292.)

\section{Qualifying for PURPA Benefits}

Two basic types of QFs exist: small power producers (SPP) and cogenerators. Small power producers generate electricity from fuels other than oil and natural gas, i.e., geothermal, biomass, hydro. A SPP is automatically a QF under PURPA if it meets specified size, fuel use, and ownership criteria. Oil or gas-fired cogeneration projects must meet additional operating and efficiency standards to be considered QFs.

General QF criteria require that the total power production capacity of a SPP (together with the capacity of other facilities owned by the same person, using the same energy resource, and located at the same site) cannot exceed $80 \mathrm{MW}$. The $80 \mathrm{MW}$ limitation on geothermal power production was eliminated in 1990 under provision of P.L. 101-575. Cogenerating QFs have no size limitation. In addition, no more than 50 percent of the equity interest in the facility can be held by an electric utility or utilities, an electric utility holding company, or combination thereof. For multi-fuel fired facilities, at least 75 percent of the total energy input must be from biomass, wastes, renewable resources, including geothermal resources, or any combination thereof. Conversely, during any calendar year, supplemental oil, natural gas, or coal use cannot exceed 25 percent of the total facility energy input.

\section{Regulatory Exemptions}

One of the three objectives of PURPA is to exempt QFs from regulation as electric utilities. FERC regulations do so by providing certain exemptions from the Federal Power Act (FPA), the Public Utility Holding Company Act of 1935, and state laws and regulations (see 18 CFR 292.601 and .602). These exemptions apply only to financial, organizational, and rate issues.

They do not affect environmental, zoning, planning, construction, licensing, or any other laws or regulations related to generating plants.

QFs are exempt from the FPA as follows:

- In general, SPPs are QFs if they have a design capacity of up to $80 \mathrm{MW}$. This restriction was removed from geothermal power production under provision of P.L. 101-575. However, only SPPs of $30 \mathrm{MW}$ or less are exempt from any part of the FPA. All qualifying cogeneration facilities are exempt.

- SPPs of under $30 \mathrm{MW}$ are exempt from the traditional rate regulation and the regulation of securities of public utilities (sections 119, 120, 203, 204, 205, 206, 208, 301, 302, and 304 of the FPA). 
QFs are not exempt from certain FPA provisions. Thus QFs:

- are not exempt from most of Part I, which deals with license and permit requirements

- are not exempt from Section 202(c) under which QFs may have to provide energy if the Economic Regulatory Administration determines there is an emergency

- are not exempt from sections 210, 211 and 212, which provide for interconnection orders by FERC and allow a utility, federal power marketing agency, or geothermal QF to seek a wheeling order against a utility in a formal FERC proceeding

- are not exempt from Section 305(c), which imposes reporting requirements on interlocking directorates

- are not exempt from Part III, which has enforcement provisions, when the enforcement provisions apply to those sections from which the QFs are not exempt (listed above).

$\underline{\text { Law }}$

Federal Power Act (FPA)

Public Utility Holding Company

Act (PUHCA)

State rules and regulations

\section{Summary of Exemptions}

from Regulations

Who is

Exempt

SPPs $30 \mathrm{MW}$ or less; all CGs

SPPs $30 \mathrm{MW}$ or less, except biomass up to $80 \mathrm{MW}$; all CGs

Same as PUHCA
From Which

Section

$119,120,203,204,205$, $206,208,301,302,304$ (regarding rate regulation and regulation of securities of public utilities)

All

All governing finance, organization, and rate issues, except those implementing subpart C of the PURPA 210 rules.

Certain QFs are exempt from all provisions of the Public Utility Holding Company Act of 1935 (PUHCA). These QFs include all geothermal, biomass, and cogeneration (CG) facilities (up to $80 \mathrm{MW}$ ). The $80 \mathrm{MW}$ limitation on geothermal power production was eliminated in 1990 under provision of P.L. 101-575. However, other SPPs are exempt only if their design capacity is 30 MW or less. 
Such review and enforcement is not confined to whether or not the state commission or nonregulated utility properly put into effect regulations implementing PURPA 210. It also can include the case-by-case application of regulations.

\section{Enforcement Procedures Summary}

\begin{tabular}{|c|c|c|}
\hline $\begin{array}{l}\text { Order of } \\
\text { Redress }\end{array}$ & $\begin{array}{l}\text { For Actions } \\
\text { by Regulated } \\
\text { Utilities }\end{array}$ & $\begin{array}{c}\text { For Actions } \\
\text { by Nonregulated } \\
\text { Utilities }\end{array}$ \\
\hline $\begin{array}{l}\text { First } \\
\text { Second } \\
\text { Third }\end{array}$ & $\begin{array}{l}\text { State commission } \\
\text { State court or FERC } \\
\text { Federal Court }\end{array}$ & $\begin{array}{l}\text { FERC } \\
\text { Federal Court }\end{array}$ \\
\hline
\end{tabular}

The QFs described immediately above also are exempt from state laws and regulations regarding electric utility rates, finances, and organization. However, they are not exempt from the state laws and regulations intended to implement subpart $C$ of PURPA 210, which governs sales and purchases between QFs and utilities. State commissions and nonregulated utilities may apply to the FERC for a waiver from this broad exemption.

\section{PURPA Enforcement}

The FERC regulations implementing PURPA set certain procedures for enforcement and redress of grievances. Persons may go to state court or, under certain circumstances, to the FERC to require a state commission or nonregulated utility to implement the PURPA regulations, or to require enforcement of the implementation by the commission or nonregulated utility. Persons seeking review of any determination made by a federal power marketing agency may go to the appropriate federal court.

A state commission or nonregulated utility may require utility cost data that is different from what the PURPA regulations require. If a QF cannot derive the utility's avoided cost from this alternative data, the $Q F$ may go to court.

Small utilities need only provide system cost data on request of a QF. If such a utility fails to provide this information, the QF may apply to the state commission (if the utility is regulated) or to FERC (for any kind of utility) for an order that it be supplied. However, the commission or FERC should take into account the burden imposed on small utilities.

If a larger utility (greater than 500 million $\mathrm{kWh} / \mathrm{year}$ in sales) does not provide the required avoided cost data, the FERC may prescribe the penalties in PURPA Section 133.

The FERC may revoke the qualifying status of a QF if appropriate. It may do so on its own initiative or if requested by some other party. It must first provide an opportunity for hearing. 


\section{Federal Agency Contracts And PURPA}

Section 210(i) of PURPA relates to the effects of contracts between federal agencies and electric utilities on PURPA Section 210 implementation. Clauses in post-1978 contracts for the wholesale sale of electricity to a utility are voided to the extent they interfere with the utility's implementation of FERC's PURPA rules. The text of the provision is:

(i) Federal Contracts. - No contract between a Federal agency and any electric utility for the sale of electric energy by such Federal agency for resale which is entered into after the date of the enactment of this Act may contain any provision which will have the effect of preventing the implementation of any rule under this section with respect to such utility. Any provision in any such contract which has such effect shall be null and void.

The term 'federal agency' means an executive agency (as defined in section 105 of title 5 of the United States Code (PURPA, Section 3(7)).

\section{Competitive Bidding}

In 1987, Martha Hesse, chairperson of the Federal Energy Regulatory Commission (FERC), proposed rules that would establish how state regulators allow independent power producers to competitively bid for the right to supply power to a utility. Although several states had established bidding programs prior to FERC's interest in the subject in order to bring order to the independent power market, FERC's proposed rules provided a catalyst for more states to become involved in competitive bidding. In theory, competitive bidding benefits consumers by establishing a market-based value for power and eliminating the risks to utilities associated with capacity expansion.

The process of competitive bidding begins when a utility identifies the need for new capacity. Well in advance of the date it begins to accept competitive bids, a utility typically publicizes the quantity and desirable attributes of its needed capacity, the terms of the offer to purchase capacity, participation criteria, and bid evaluation criteria.

Competitive bidding may affect PURPA development in several ways. Competitive bidding would likely affect the price paid for PURPA resources and therefore the return a PURPA developer receives. For example, a developer wishes to build a $\mathrm{QF}$. If the utility were to pay the developer a rate based on an administratively-determined avoided cost, the developer would receive a favorable retum. However, if the rate were to be set through competitive bidding, the developer could conceivably earn a lower return. This type of situation would reduce incentives for developing PURPA resources. On the other hand, in a different situation, competitive bidding could increase the prices paid for non-utility generated power, thereby positively affecting the development of PURPA resources.

The actual influence of competitive bidding on price would depend heavily on how market forces replace administratively-set avoided costs and on what rombination of least-cost resources are developed. For example, competitive bidding could lower a utility's marginal cost of electri- 
city, resulting in higher profits. This improved profitability might lead the utility to purchase more power from PURPA resources, as long as the cost of those resources remains lower than the cost of utility-developed resources.

Geothermal developers, whether a PURPA developer or successful competitive bidder, will need transmission access to deliver their product. PURPA only requires that utilities give transmission access to QF developers within the utility's own service area. Thus, if rules governing wheeling are not changed and if provisions are not made for transmission and wheeling, the competitive bidding market will be severely limited since utilities might receive bids only from resources located within their own service areas. This would likely act to restrict development of PURPA resources and would surely have a very negative effect on development of geothermal resources which, for the most part, are located in rural areas.

\section{Regional Institutions}

There are two regional institutions in the Pacific Northwest that affect QFs. They are the Northwest Power Planning Council (NPPC) (created by the Northwest Power Act, P.L. 96-501, 94 stat. 2967; 16 USC 839-839h) and the region's federal power marketing agency, the Bonneville Power Administration (BPA). The NPPC is a planning authority. BPA provides electricity and transmission services.

The institutions are closely linked. The NPPC was created by the Northwest Power Act, P.L. 96501, 94 stat. 2967; 16 USC 839-839h. The Northwest Power Act's second and third resource priorities are "renewable resources" and "resources utilizing waste heat or generating resources of high fuel conversion efficiency" (Section 4(e)(1)). Also, Section 6(e)(1) says the BPA "Administrator shall, to the maximum extent practical,...(use his authority)...to acquire conservation...and renewable resources...and to provide credits and technical and financial assistance for the development and implementation of such resources..." The following definitions from Section 3 of the Act apply to most QF technologies, whether the power is for sale or on-site use.

(16) "Renewable resource" means a resource which utilizes solar, wind, hydro, geothermal, biomass, or similar sources of energy and which either is used for electric power generation or will reduce the electric power requirements of a consumer, including by direct application.

(19) "Resource" means -

(A) electric power, including the actual or planned electric power capability of generating facilities, or

(B) actual or planned load reduction resulting from direct application of a renewable energy resource by a consumer, or from a conservation measure. 
All BPA-acquired resources must be cost-effective. The Act's cost-effectiveness standard is defined in Section 3 and appears below. On a conceptual basis, it is remarkably similar to PURPA's avoided cost standard as defined in 18 CFR 292.101(a)(6) and applied by 18 CFR 292.304.

(4)(A) "Cost-effective," when applied to any measure or resource referred to in this Act, means that such measure or resource must be forecast -

(i) to be reliable and available within the time it is needed, and

(ii) to meet or reduce the electric power demand, as determined by the Council or the Administrator, as appropriate, of the consumers of the customers at an estimated incremental system cost no greater than that of the least-cost similarly reliable and available alternative measure or resource, or any combination thereof.

(B) For purposes of this paragraph, the term "system cost" means an estimate of all direct costs of a measure or resource over its effective life, including, if applicable, the cost of distribution and transmission to the consumer and, among other factors, waste disposal costs, end-of-cycle costs, and fuel costs (including projected increases), and such quantifiable environmental costs and benefits as the Administrator determines, on the basis of a methodology developed by the Council as part of the plan, or in the absence of the plan by the Administrator, are directly attributable to such measure or resource.

(C) In determining the amount of power that a conservation measure or other resource may be expected to save or to produce, the Council or the Administrator, as the case may be, shall take into account projected realization factors and plant factors, including appropriate historical experience with similar measures or resources.

\section{Northwest Power Planning Council (NPPC)}

The NPPC has three missions, all of which affect QFs. They are the Power Plan, Fish and Wildlife Program, and Public Involvement Program. The regional Power Plan is periodically published by the NPPC. In it are forecasts of loads, evaluations of resources, a preferred supply strategy, and an action plan. The plan says how the renewable resources priority should be put into effect. The priorities will be important in determining how BPA acquires new resources. Except for conservation, the priority guides choices that cost the same. Conservation has a 10 percent cost advantage. Program directives are defined in the action plan, many of which address renewable resources issues. Resolving the issues can facilitate QF development.

The 1986 plan addressed the need for BPA to have the ability to acquire the capability of generating resources. Item 7 of the action plan set the following objective for BPA: 
Develop an acquisition process and supporting activities designed to encourage the development of cost-effective priority resources, including conservation, renewables and highefficiency resources, and lost opportunity resources, while also developing the capability to acquire conventional resources, when and if needed.

A number of activities were given to achieve the objective. Key among them, for $Q F s$ are:

...Develop a comprehensive acquisition process. An important part of any process to acquire resources is the purchase price of the resource. The concept, embodied in the Public Utility Regulatory Policies Act, of offering to pay the "avoided cost" (or what would have been paid for the development of the next planned resource), for qualified resources has been effective at encouraging the development of dispersed and renewable resources. Bonneville's acquisition process should embody this concept. Offering prices should be based upon the present value of these resources to Bonneville, including the effects of expected loads put on Bonneville by investor-owned utilities, and should consider characteristics of prospective resources which affect this value, such as dispatchability, and whether acquisition is constrained to a certain time period (a lost opportunity resource). Offering prices should be periodically adjusted to reflect changing demand forecasts, contracted loads and other conditions. The offer should include conditions to ensure that resource development is consistent with requirements of the plan and the Northwest Power Act.

Develop and demonstrate general approaches to contracting with utilities and independent power developers. When the region needs power, it is quite likely that utilities will not be the only developers of resources. Independent developers will likely sponsor many dispersed generating resources, conservation resources and, possibly, central station power plants. The intent of this activity is to encourage the orderly development of small-scale and high priority resources and to identify and acquire lost opportunity resources as these become cost effective.

\section{Bonneville Power Administration}

The BPA is the Northwest's federal power marketing agency. In this role it supplies most of the electricity that customer-owned utilities (COUs) sell retail customers. In fact, most utilities throughout the region obtain at least some power from BPA. BPA supplies 48 percent of the region's power. The regional transmission grid is operated by BPA and transmission services are extensively used by utilities. To some extent transmission services are also available to QFs.

The Northwest Power Act expanded the role of BPA in the region. Prior to the Act, BPA's main function was to distribute generation from federally-owned dams. Now, BPA is involved in many activities that affect QFs. BPA has sponsored numerous studies of renewable resources throughout the region. Resources and technologies that have been studied include hydropower, wind, cogeneration, geothermal, and municipal solid waste. The results of these activities can be very useful to $\mathrm{QF}$ developers. 
In response to the NPPC's Power Plan, BPA is working on a resources acquisition policy and program. When fully implemented, the BPA acquisition process will be one way for resource developers to market the output from renewable resource generation projects. Section 6 of the Northwest Power Act covers resources acquisition and the process will need to conform to the Act. The first BPA competitive acquisition process calling for the purchase of resources was announced in 1991. 


\section{BASIC INFORMATION FOR PLANS OF OPERATION (FEDERAL LANDS)}

1. Title Page showing:

- Lease number(s) or unit agreement name

- Known Geothermal Resources Area (KGRA) name, if any

- Location (section, township, range, base, and meridian; county and state); name, address and the phone number for lessee or operator, contractor, and field representatives

- Brief description of proposed operations and objectives

- Estimated starting and completion dates for each activity

2. Maps:

a. Topographic Map - Orthophoto quad or equivalent (preferred scale 1:24,000), and, if necessary, written explanation presenting:

- Federal lease boundaries and serial numbers

- Fee lease boundaries, ownership, and lessees, if known

- Names, addresses, and phone numbers of private surface owners of, and those adjacent to, lands to be disturbed by proposed operations

- Proposed existing and abandoned wells

- Existing and planned access roads

- Water supplies and road building materials

- Campsites, airstrips, and other support facilities

- Homes and other pertinent surface facilities

b. Large-scale Map - Showing layout of the operations site (equipment, facilities, sumps, etc.)

c. Detailed Engineering Plan and Profile drawings - For any site, road, or other construction or modification located on rugged terrain, potentially unstable ground, or environmentally sensitive areas:

3. Narrative Statement containing:

- Measures to prevent or control: fires; soil erosion; pollution of surface and groundwater; air and noise pollution; hazards to public health and safety; damage to fish, wildlife, natural resources; and areas of cultural, historical, or archaeological value

- Methods for disposing of waste materials (including sanitary facilities)

- Provisions for monitoring air quality, noise, drilling mediums, and produced gases, liquids, and solids 
- Information about construction and drilling personnel (crew size, housing, and support facilities)

4. Certified Statement - The presence of or absence of any cultural, historical, or native American religious site that may be disturbed by operations. The statement must be made by a person acceptable to the surface manager, and a copy must be submitted to the surface manager and the authorized officer of the BLM. A certified statement of the presence or absence of any rare, threatened, or endangered animal or plant species may also be required.

5. Emergency Contingency Plans including:

An Accident and Injury contingency plan for all plans; a blowout contingency plan where drilling is proposed; and when required by the authorized officer, contingency plans for the control of fires, pollution incidents, or hazards resulting from adverse weather conditions. Each contingency plan shall contain:

- A description of adverse effects the emergency would have on operations, personnel, public health, and the environment

- Measures to control these effects, including shutdown procedures

- Responsibilities of each employee in an emergency situation

- Information about personnel with special training or experience with emergency procedures

- Where to obtain emergency control services and medical aid

- Emergency notification list (names, addresses, and telephone numbers of pertinent federal, state, and local regulatory, law enforcement, and emergency service offices)

\section{APPLICABLE REFERENCES: 43 CFR 3262.4}

6. Environmental Information - Submittal of the following information will facilitate the approval process:

- Regional and local geology, hydrology, and meteorology

- Potential geologic hazards (active faults, landslide areas, etc.)

- Soil, air, noise, and visual studies

- Fauna and flora (associations, communities, habitats, life patterns, etc.)

- Current and prospective land uses, including recreational areas

- Local economy

- Sites of cultural, historical, or archaeological value

- Wildlife migration routes, watering holes, and habitats 


\section{IDAHO}

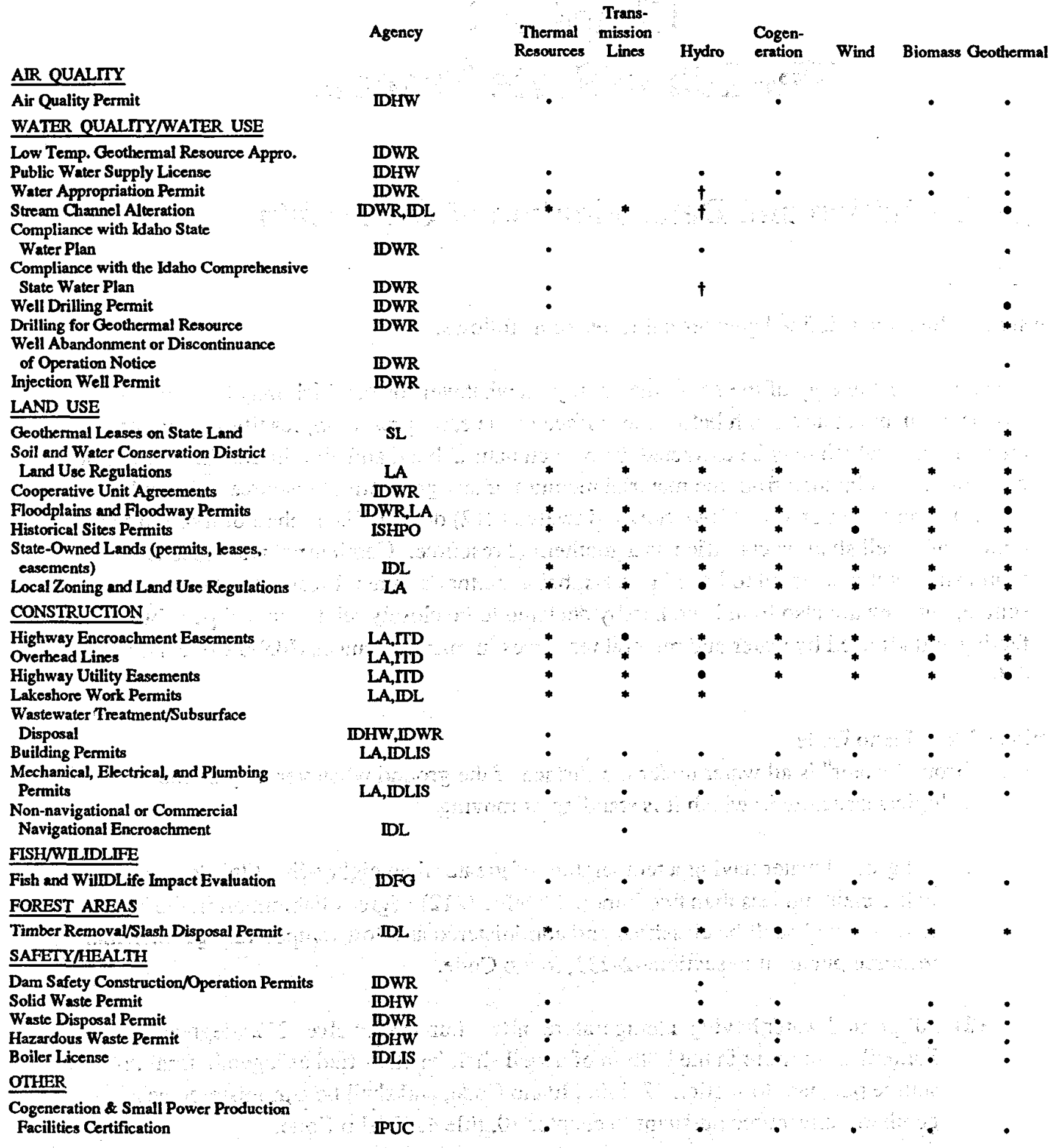

\section{Agencies}

IDWR Idaho Department of Water Resources

IDHW Idaho Department of Health and Welfare

LA Local agencies

IDL Idaho Department of Lands

ISHPO Idaho State Historic Preservation Offioe
IID Idaho Transportation Department

IDFG Idaho Department of Fish and Game

IDLIS I Iaho Department of Labor and Industrial Services

IPUC Public Utilities Commission

\section{Key}

$\dagger=$ Permit required

- Permit may be required

- Site specific 


\section{Chapter 2 \\ The Idaho State Process}

\section{Legal Definition and Determination of Ownership}

\section{Definition}

The state of Idaho has defined geothermal resource as follows:

the natural heat energy of the earth, the energy, in whatever form, which may be found in any position and at any depth below the surface of the earth present in, resulting from, or created by, or which may be extracted from, such natural heat, and all minerals in solution or other products obtained from the material medium of any geothermal resource. Groundwater having a temperature of two hundred twelve (212) degrees Fahrenheit or more in the bottom of a well shall be classified as a geothermal resource. Geothermal resources are found and hereby declared to be sui generis, being neither a mineral resource nor a water resource, but they are also found and hereby declared to be closely related to and possibly affecting and affected by water and mineral resources in many instances (Idaho Code \$ 424002).

\section{Section 42-230 Idaho Code}

(a) "Ground water" is all water under the surface of the ground whatever may be the geological structure in which it is standing or moving.

(1) All ground water having a temperature of greater than eighty-five (85) degrees Fahrenheit and less than two hundred twelve (212) degrees Fahrenheit in the bottom of a well shall be classified and administered as a low temperature geother-mal resource pursuant to section 42-233, Idaho Code.

(2) All ground water having a temperature of two hundred twelve (212) degrees Fahrenheit or more in the bottom of a well shall be classified as a geothermal resource pursuant to section 42-4002, Idaho Code, and shall be administered as a geothermal resource pursuant to chapter 40 , title 42 , Idaho Code.

(g) "Low temperature geothermal resource well" means a well which is capable of producing a low temperature geothermal resource from which fluids can be produced which have value by virtue of the heat contained therein.

\section{Ownership}

Before a project can begin, the access and development rights need to be secured. In Idaho, the state asserts general ownership over the waters of the state. TJ.e state also specifically claims 
ownership of all geothermal resources underlying state and school lands. However, state lands are those in which the state of Idaho owns either the surface rights, the mineral rights, or both. No right to seek, obtain, or use geothermal resources has passed or shall pass with any existing or future lease of state or school lands, including but not limited to, mineral leases and leases issued under chapter 8, title 47, Idaho Code (Idaho Code § 47-1602).

The state of Idaho claims the right to regulate the development and use of all of the geothermal resources within the state as natural resources of limited quantity and of a unique value to all of the people of the state (Idaho Geothermal Resources Act, 1972, Ch. 301, § 2).

The legislature has therefore declared that it is the policy and purpose of the state to maximize the benefits to the entire state derived from use of geothermal resources, while minimizing the detriments and costs of all kinds that could result from their use. This policy and purpose has been enacted by regulating geothermal resource exploration and development in the public interest (Idaho Geothermal Resources Act, 1972, Ch. 301, § 2).

In Idaho, a drilling permit must be obtained prior to drilling any well. Furthermore, an application for permit to appropriate water must be filed and approved prior to withdrawal of water from the well except when the geothermal well yields water used as a "mineral source, an energy source, or as a material medium" (Idaho Code § 42-4003).

Although Idaho has attempted to minimize conflicts between geothermal and groundwater usage by differentiating between waters that have a beneficial use* (groundwater that must be appropriated) and those that cannot be used for purposes other than for their energy or mineral content (and require a geothermal permit), it is advisable to obtain both a geothermal and water permit to protect and secure the developer's interests.

\section{Obtaining Access to Geothermal Resources}

\section{State Lands}

Geothermal leasing rules and regulations have been adopted by the Idaho State Board of Land Commissioners (Board) pursuant to Idaho Code title 47, chapter 16 and Idaho Code title 67, chapter 52, and are intended to satisfy the board's mandate (Idaho Constitution, Article 9) to "maximize the long-term return on state mineral lands by encouraging leasing and development of the geothermal resources while preventing waste and protecting the other natural resources of the state mineral lands."

\footnotetext{
*"Beneficial Use" is one or more of the recognized beneficial uses of water including but not limited to, domestic, municipal, irrigation, hydropower generation, industrial, commercial, recreation, stockwatering and fish propagation uses for which permits to appropriate water can be issued as well as other uses which provide a benefit to the user of the water as determined by the director. Industrial use as used for purposes of these rules and regulations includes, but is not limited to, manufacturing, mining, and processing uses of water.
} 


\section{Qualified Applicants and Lessees}

Any person is qualified to lease the geothermal resources on state lands or take or hold an interest therein unless the Board of Land Commissioners (Board) first determines, after notice and hearing, for good cause shown, that a person is disqualified from leasing or taking or holding an interest in geothermal resources in state lands.

\section{Application and Processing-Simultaneous Filings}

An application for a geothermal resources lease must be submitted to the Idaho Department of Lands in Boise on a Department form or an exact copy. It shall contain the following: name, address, telephone number, and the notarized signature of the applicant; power of attorney if applicant is an agent; legal description of lands applied for, and an application fee.

Applications for a geothermal resource lease are considered in the order in which they are filed. If two or more applications be received on the same day for the same site, they will be considered as simultaneous filings.

Conflicts resulting from simultaneous filings will be resolved by a competitive auction held within $\mathbf{3 0}$ days of receipt of the simultaneous filings.

The Department gives notice to the conflicting applicants by certified mail. The notice contains the legal description of the lands in conflict, the date, time, and place of the competitive auction.

\section{Term}

All leases are for a primary term of 10 years from the effective date of the lease. The effective date of the lease being the first day of the month following the Board's approval.

If, at the expiration of the primary term of the lease, geothermal resources are not being produced or demonstrably capable of being produced from the leased land, but the lessee is actively engaged in drilling operations 1,000 feet or deeper, then the lease shall continue in force so long as drilling operations are being diligently and continuously prosecuted on the leased land or upon lands with which the leased land is unitized. Drilling operations shall be considered to be diligently and continuously prosecuted if not more than 120 days elapses between the completion or abandonment of one well and the beginning of operations for the drilling of another well. The director may extend the time for an additional period, not to exceed 120 days for good cause. A written request must be received by the Director at least 10 calendar days before the expiration of the initial 120-day period.

If geothermal resources are produced or utilized in paying quantities within the primary term of the lease or extended, the lease shall continue for so long thereafter as geothermal resources are produced or utilized in paying quantities, but the lease shall in no event continue for more than 40 years after the end of the primary term. The lessee shall, however, have a preferential right to a renewal of his lease for a second 40-year term upon such terms and conditions as the Board 
deems appropriate after notice and an opportunity to be heard, if at the end of the first 40-year term geothermal resources are produced or utilized in paying quantities; provided, however, that the royalty during the second 40 -year term shall not exceed 15 percent.

The lessee must use due diligence to market or utilize geothermal resources in paying quantities. If leased land is capable of producing geothermal resources in paying quantities, but production is shut-in, the lease shall continue in force upon payment of rentals for the duration of the primary term or 5 years after shut-in, whichever is longer. If the director determines that the lessee is proceeding diligently to acquire a contract to sell or to utilize the production or is progressing with installations needed for production, the lease shall continue in force for an additional 5 years, upon payment of rentals, otherwise the lease may be terminated by the Board. The Director shall continue to review shut-in leases every 5 years until production and payment of royalties takes place or the lease is terminated by the Board for lessee's lack of due diligence or surrendered by the lessee.

A lease that has been extended by reason of production or utilization of geothermal resources and which has been determined by the Director to be incapable of further commercial production and utilization may be further extended for 5 years if one or more valuable by-products are produced in commercial quantities. The Board may extend the lease for one or more additional 5year terms upon such terms and conditions as the Board deems fit to allow continued production of one or more valuable by-products in commercial quantities.

\section{Rentals}

Lease holder must pay to the state of Idaho in advance each year an annual rental for each acre or fraction thereof under lease. The annual rental for the first year of the term shall be due and payable and shall be received in the offices of the Department of Land in Boise, together with a lease agreement executed by lessee within 30 days of the date of notice of approval or award. The Department will notify the applicant or his representative designated in the application to lease by certified or registered mail of the Board's approval of a lease and specify the exact amount of rental due and the bond requirements. Failure to return an executed lease together with the first year rental and bond within 30 days results in automatic rejection of the application without further action of the Director or Board. Second year and subsequent rental payments must be received in the office of the Department in Boise on or before the anniversary date of the lease. Failure to pay exact rental shall constitute grounds for immediate termination of the lease by the Director who shall note the termination on the official records of the Department.

Annual rentals for each acre or fraction thereof under lease is as follows:

$\$ 1.00$ per acre-for the first 5 years;

$\$ 2.00$ per acre - for the second 5 years;

$\$ 3.00$ per acre-thereafter. 


\section{Royalties}

The lessee must pay a royalty of 10 percent of the amount or value of geothermal resources, or any other form of heat or energy derived from production under the lease and sold or utilized by the lessee or reasonably susceptible to sale or utilization by the lessee, unless used or consumed by lessee in his production operations.

In addition, a royalty of 5 percent of the amount or value of any associated by-product derived from production under the lease and sold or utilized or reasonably susceptible of sale or utilization by the lessee must be paid.

Royalties are due and payable monthly in the office of the Idaho Department of Lands in Boise on or before the last day of the calendar month following the month in which the geothermal resources and/or their associated by-products are produced and utilized or sold.

\section{Size of a Leasable Tract}

A geothermal resource lease must include all available state lands within a section, at time of lease issuance, with only lands from one section allowed to be included in any one lease. A geothermal resource lease on state lands will therefore be limited to 640.0 acres, or one section, should the entire section be larger than 640.0 acres.

Geothermal resources leases may be issued for state lands underlying navigable water courses. Operations in the beds of navigable water courses will, however, not be authorized except in extraordinary circumstances and then only with express written approval of the Board upon such conditions and security as the Director deems appropriate.

\section{Known Geothermal Resource Areas: Public Auction}

The Director may from time to time designate certain state lands as being within a Known Geothermal Resources Area (KGRA). Geothermal resources leases issued on KGRA lands shall be upon a competitive bid basis at public auction under such terms and conditions as the Director sets. Before leasing geothermal resources owned by the state within a KGRA, the Director will advertise the availability of these state lands within a KGRA by posting a notice to appear at least once in a newspaper of general circulation in Idaho at least 30 days before the date of the public auction, and mailing a copy to interested persons on a geothermal resources mailing list. Prevailing bidders shall pay the costs of the public auction and advertising in proportion to the cost of acreage leased in said auction.

The Director will consult with the Idaho Department of Water Resources prior to designating state lands as being within a KGRA. Actual production in the vicinity of state lands shall be the primary evidence for KGRA designation. 


\section{Land Surface Use Rights and Obligations}

Any time after formal approval by the Board of a lease application, the lessee may enter upon the leased lands for casual exploration or inspection without notice to the Director. The lessee may not enter upon the leased lands for exploration operations using motorized equipment or otherwise engaging in operations which may lead to an appreciable disturbance or damage to lands, timber, other resources, or improvements on or adjacent to the leased lands until there is in existence a fully executed lease.

Before entering upon the leased lands for exploration operations or otherwise engaging in operations which may lead to an appreciable disturbance or damage to lands, timber, other resources, or improvements on or adjacent to the leased lands, the lessee must file with the Director, in writing, notice of the following:

Name and address of the operator

Location of the operation and the starting date and estimated completion date

Anticipated size or scope of the operations in terms of manpower and equipment, and the general method of operation.

Prior to the initiation of operations to drill a well for any purpose to 1,000 feet or deeper, the lessee must file with the Director for approval a plan of operations and increase the surety bond to $\$ 10,000$.

Lessee must reclaim all state lands disturbed by exploration, development, operation, and marketing of geothermal resources in accordance with applicable reclamation procedures contained in Idaho Code sections 47-1509 and 47-1510 as now existing and hereafter amended. Lessee must conserve, segregate, stockpile, and protect topsoil to enhance reclamation. Lessee must take all necessary steps in the exploration, development, operation, and marketing of geothermal resources to avoid a threat to life or property or an unreasonable risk to subsurface, surface, or atmospheric resources.

\section{Diligent Exploration}

Each lease will include provisions for the diligent exploration of the leased resources until there is production in commercial quantities from the state lands subject to lease, and failure to perform such exploration may subject the lease to termination. Diligent exploration means exploration operations on or related to the leased lands, including without limitation geochemical surveys, heat flow measurements, core drilling, or drilling of a test well. A report of all exploration operations and expenditures must be submitted to the Director at the close of each lease year. 


\section{Operations Under the Lease}

The Director is authorized to shut down any operations which he determines are unsafe or are causing or can cause pollution of the natural environment or waste of natural resources including geothermal resources upon failure by lessee to take timely, corrective measures ordered by the Director.

Prior to initiation of operations to drill a well for any purpose to 1,000 feet or deeper, lessees must submit to the Director for his approval a plan of operations. The plan must include:

The proposed location of each well including a layout showing the position of the mud tanks, reserve pits, cooling towers, pipe rack, etc.

Existing and planned access, access controls, and lateral roads

Location and source of water supply and road building material

Location of camp sites, air-strips, and other supporting facilities

Other areas of potential surface disturbance

The topographic features of the land and the drainage patterns

Methods for disposing of waste material

A narrative statement describing the proposed measure to be taken for protection of the environment, including, but not limited to the prevention or control of (1) fires, (2) soil erosion, (3) pollution of the surface and groundwater, (4) damage to fish and wildlife or other natural resources, (5) air and noise pollution, and (6) hazards to public health and safety during lease activities

All pertinent information or data which the Director may require to support the plan of operations for the utilization of geothermal resources and the protection of the environment

Provisions for monitoring deemed necessary by the Director to ensure compliance with these rules for the operations under the plan

The information required may be shown on a map or maps of sufficient scale available from state or federal sources

When necessary or advisable, the Director may require that adequate samples be taken and tests or surveys be made using techniques consistent with industry practice, without cost to the state of Idaho, to determine the identify and character of formations; the presence of geothermal resources, water, or reservoir energy; the quantity and quality of geothermal, water, or reservoir energy; the amount and direction of deviation of any well from the vertical; formation, casing and tubing pressures, temperatures, rate of heat and fluid flow, and whether operations are conducted in a manner looking to the protection of the interest of the state of Idaho. 
The leaseholder must promptly plug and abandon any well on the leased land that is not used or useful, in conformity with regulations promulgated by the Idaho Department of Water Resources or its predecessor agency. No production well may be abandoned until its lack of capacity for further profitable production of geothermal resources has been demonstrated to the satisfaction of the Director. A producible well may be abandoned only after receipt of written approval by the Director. Equipment must be removed, and premises at the well site must be restored as near as reasonably possible to its original condition immediately after plugging operations are completed on any well except as otherwise authorized by the Director. Drilling equipment must not be removed from any suspended drilling well without taking adequate measures to close the well and protect subsurface resources. Upon failure of lessee to comply with any requirements, the Director is authorized to cause the work to be performed at the expense of the lessee and the surety.

\section{Assignments}

A total or partial assignment of a lease must be approved in writing by the Director and no assignment may be effective until written approval is given. An assignment shall take effect the first day of the month following the approval of the assignment.

\section{Unit or Cooperative Plans of Development or Operation}

For the purpose of conserving the natural resources of any geothermal pool, field, or like area, lessees under lease issued by the Board are authorized, with the written consent of the Director, to commit the state lands to unit, cooperative, or other plans of development or operation with other state lands, federal lands, privately-owned lands, or Indian lands. Applications to unitize must be filed with the Director who shall certify whether such plan is necessary or advisable in the public interest. The Director may require whatever documents or data he or she deems necessary. To implement such unitization, the Board may, with the consent of its lessees, modify and change any and all terms of leases issued by it which are committed to such unit, cooperative, or other plans of development or operations.

The term of all leases included in any cooperative or unit plan of development or operation shall be extended automatically for the term of such unit or cooperative agreement.

\section{Preferential Rights Upon Discovery of Unleased Minerals, Oil, Gas, and Other Hydrocarbons}

Any lessee who discovers any minerals or oil, gas, or other hydrocarbons on lands leased from the Board for development of geothermal resources has a preference right to a state lease covering such mineral, or oil, gas, or hydrocarbons, provided the unleased minerals at the time of discovery are not included within a mineral location under Idaho Code section 47-703, a mineral lease or mineral lease application of another party, and provided that the oil, gas, or other hydrocarbons are not under lease or subject to a pending lease application under Idaho Code Section 47-801. 


\section{Surrender, Termination, Expiration of Lease}

A lease, or any surveyed subdivision of the area covered by such lease, may be surrendered by the record title holder by filing a written relinquishment in the office of the Idaho Department of Lands in Boise, on a form fumished by the Director, provided that a partial relinquishment does not reduce the remaining acreage in the lease to less than 40 acres.

Any lease may be immediately terminated by the Director if the lessee fails to pay the rental on or before the anniversary date of the lease. However, if the time for payment falls upon any day in which the office of the Department in Boise is not open, payment received on the next official working day shall be deemed to be timely. The termination of the lease for failure to pay the rental shall be noted on the official records of the Department. Upon termination the lands included in such lease may become subject to leasing as provided by these rules.

A lease may be terminated by the Director for any violation of Idaho rules, or the lease terms, 60 days after notice of the violation has been given to lessee by personal service or certified mail, return receipt requested, to the address of record last appearing in the files of the Department, unless the violation has been corrected, or the violation is one that cannot be corrected within the notice period and the lessee has in good faith commenced within the notice period to correct the violation and thereafter proceeds diligently to complete the correction.

\section{Bond Requirements}

Concurrent with the execution of the lease by the lessee, lessee must furnish to director a good and sufficient bond in the amount of $\$ 2,000$ in favor of the state of Idaho, conditioned on the payment of all damages to the land surface and all improvements thereon, including without limitation crops on the lands, whether or not the lands under this lease have been sold or leased by the Board for any other purpose; conditioned also upon compliance by lessee of his obligations under this lease and these rules. Prior to initiation of operations to drill a well for any purpose to 1,000 feet or deeper, the lessee must increase such bond to the amount of $\$ 10,000$. The Director may require a new bond in a greater amount at any time after operations have begun, upon a finding that such action is reasonably necessary to protect state resources.

\section{Liability Insurance}

Prior to entry upon the leased lands for other than casual exploration or inspection, the lessee must purchase and maintain, for the duration of the lease, the following liability insurance:

public Liability Insurance in the form of comprehensive general liability or commercial general liability including the following:

blanket contractual

products and completed operation

premises liability

collapse, explosion, underground hazard (for drilling operation 1,000 feet or deeper)

Workers' Compensation and Employers' Liability as required by law. 
Limits of Liability: All such coverage required shall have a combined single limit (CSL), by virtue of one or more policies, on a per-occurrence basis, in amounts not less than 1 million dollars $(\$ 1,000,000)$.

\section{Right of Cancellation by the Board}

The Board reserves the right to cancel any geothermal resources lease upon failure by the lessee to exercise due diligence or care in the prosecution of his operations or upon failure by lessee to comply with the terms and conditions stated in the lease and with all laws of the state of Idaho, including without limitation these rules.

\section{Indian Lands}

In the 1850 s, a series of treaties were negotiated between the United States and a number of the Indian tribes by Isaac Stevens.

In exchange for giving the United States title to most of their land, the Indians retained reservations for homelands as well as a right to continue hunting and fishing at their usual and accustomed places, both on and off the reservation.

All of the so called Stevens treaties were negotiated, executed, and ratified by Congress well before statehood. In the ensuing decades, the treaties were interpreted by the federal courts. The court rulings followed earlier Supreme Court rules concerning Indian treaties and established several basic principals. Most fundamentally, the rights retained by the tribes are reserved rights, that is they are rights retained by the tribes at the time of treaty-making, and not given to them by the United States.

Each tribe that signed a treaty has a property right to the use of the resources in question. As a property right retained from before statehood, treaty rights are in the nature of easements on other real property interests.

Treaty rights have also been found by the federal courts to include an environmental right. For example, court decisions have forbidden actions that would inundate usual and accustomed fishing sites, dewater fish habitat, or degrade water quality to the detriment of the fishery.

Indian water rights stem from a 1908 Supreme Court decision which stated that when land was set aside for reservations, it was implied that water was also reserved for tribal uses. It does not matter if the water has been put to use or not, it is still reserved for use on the Indian reservation.

Though altered somewhat by subsequent court cases, the Winters Doctrine, as this decision is known, remains the basis for Indian water rights. The Winters Doctrine usually refers to direct water use, rather than the protection of instream flows for fish habitat. There are many Winters Doctrine-based water claim cases currently in state and federal courts. The outcome of these cases could have a profound impact on current western United States water use. 
In 1984 the EPA announced that it would "work directly with Indian tribal governments on a one-to-one basis." This policy recognizes tribal governments as sovereign entities with primary responsibility for reservation environmental issues, such as air and water quality and related matters. This means that the tribes can contract directly with the EPA to administer the Clean Water Act, the Clean Air Act, and similar environmental programs on their reservations (Brown, 1991).

Individual Indian lands (allotments) held in trust by the U.S. or tribal land held in trust by the U.S. can be permitted or leased for mineral development under authority of a March 3,1909, act, Leases of Allotted Lands for Mining Purposes, or a May 11, 1938, act, Leases of Unalloted Lands for Mining Purposes, Duration of Leases, and the 1982 Indian Mineral Development Act. These acts are regulated by 25 CFR 211,212 , and 216 , and by 43 CFR 3100 through 3590 . The Bureau of Indian Affairs (BIA) is responsible for exploration permit, lease approval, and administration. The BIA is responsible for operational supervision of prospecting and development.

Access to Indian lands for non-disturbing surface exploration requires written agreement between operators and Indian land owners. Surface disturbing activities, including prospecting and development, require approval by the BIA and BLM. The point of first contact should be between the prospective operator and tribal governments.

Finally, and perhaps most significantly, the tribes as governmental entities have a right to manage their resources. This means that the tribes undertake all activities necessary to adequately manage the resource, including protecting the environment necessary to sustain the resource (see The Federal Process, pages 9-65, for additional information on Indian lands).

\section{Tribal Requirements}

Development on tribal reservation land may be subject to tribal laws not detailed in this guide. The appropriate tribal planning office should be contacted prior to conducting activities on tribal land. For a list of tribal contacts, see Appendix 1F.

When a project is on non-tribal lands but may affect treaty-reserved resources or areas of tribal significance, agencies have an obligation and responsibility to consult with tribal governments during the project review process. Mitigation may be required to protect treaty rights.

Prevention of damage to Indian graves or artifacts is required. Unlawful removal or mutilation of artifacts or burial sites is punishable as a felony under state law.

\section{Private Lands}

Developable geothermal resources are often found on private lands. Accordingly, one of the first activities is to gain access. Access to private land can be obtained by sale, lease, permit, option, or any other mutual agreement with the owner of the surface property and geothermal estate. 
Landowners may permit access prior to a lease or purchase option. This allows the developer to conduct agreed upon preliminary exploration activities. Such activities could include geological and geophysical investigations that are non-surface disturbing and the drilling of temperature gradient holes. (A state well drilling permit is required for exploratory drilling on private land.) Additional federal, state, and/or local permits are required for continued development. These are covered in subsequent sections.

\section{Sales}

A landowner who sells property to a geothermal developer transfers all interest and control in the property and its geothermal resources for a fixed price. The landowner does not incur the risks of development. The developer pays the market value of the property, taking into consideration any value added by the resource. A landowner who is paid in full need not be concerned with the development. However, a landowner who is to be paid over time from the project's geothermal resource or electricity sales revenues may retain some control over the property and its development as security for future payment. A landowner who wants to use the property for farming or grazing can lease back the property sold to the developer.

\section{Lease}

Instead of selling the property, the landowner may rent or lease it to the geothermal developer for a fixed term. In most instances, access to private land is obtained through a geothermal lease. Leasing terms generally include length of lease, royalty payments, lease fees, and stipulations governing exploration and development activities. Terms are often based on state and federal oil, gas, and geothermal leasing guidelines. A lease or rental agreement allows the landowner to retain some control over the development and use of the land.

\section{Option to Purchase or Lease}

Instead of an immediate purchase or lease, the developer can buy an option by paying the landowner a sum, usually a small percentage of the property value. The option holds the property off the market while the developer determines whether to make a final purchase or lease. The terms of the final purchase or lease are negotiated and set forth in the option agreement.

Two agreements are needed for the developer to obtain the right to purchase or lease the property later and the right to install testing devices or completing an exploration process: an option's agreement and a short-term lease or license agreement. Either a license or lease allows the developer to use the land during the option period.

At the end of the option period, the developer must decide whether to purchase or lease the property at the price and terms in the option agreement; or to give up all interest in the land. An option assures that the developer can buy or lease the property for a set price in the future. For instance, the developer can buy an option to purchase or lease the property at a low price in 5 years. Tests may show that the property has valuable resources. The developer can exercise 
the option at the low price despite the increased value of the land. However, if tests show that the geothermal resource is less valuable than thought, the developer is not bound to buy or lease the property.

The landowner cannot accept a better offer during the option period. The option price should adequately compensate the landowner for keeping the property off the market. The value of an option right depends on the length of the option period and the strength of the resource. If more than one developer wants to buy an option, the competition will increase the value of an option.

\section{Right of First Refusal}

A right of first refusal is often confused with an option to purchase. Unlike an option, a right of first refusal does not set a price for the property. A developer who buys a right of first refusal merely obtains a right to match any offer to buy the property. Thus, a landowner who receives an acceptable offer from a third party would be required to communicate the offer to the developer. The developer then has the right to match the offer and obtain the property or allow the property to be purchased by the offeror.

A landowner may specify that a right of first refusal does not apply to offers to purchase made by specific parties such as family members. This allows the landowner to transfer ownership within a family while granting a developer a right of first refusal on offers made by others.

If the area of interest is already under lease for other purposes such as farming or grazing, the developer must secure permission through easement from the lessee for surface access rights.

\section{Easement}

A developer can negotiate an easement for access with adjoining landowners. An easement is a right to make limited use of real property in airspace. A landowner can sell an easement granting the developer the right to use the space across and above the property. This grants a positive right. An adjoining landowner may also agree to restrict vegetation, structures, or other objects that would impair or obstruct transmission lines. This is called negative easement.

An easement may be perpetual or for a specified time. Once granted, a perpetual easement may not be terminated except as stated in the easement, by court decree based upon abandonment or changed conditions, or by agreement of the parties.

To be effective, an easement must be in writing and be recorded in county property records. A landowner who has granted an easement can sell the property but the new owner will be bound by the terms of the easement. Similarly, if the developer sells the property benefited by the easement, the new owner will be entitled to the same rights as the developer. This is what the law means when it says that the easement is appurtenant to the land and follows with the real property benefited and burdened by the easement. 
Easements may also be granted for uses other than access to energy resources. The uses of the easement are stated in the easement. For instance, an owner of adjoining property may grant a developer an easement to cross the property to install and repair equipment or the right to erect and maintain transmission lines. Easements from several parties may be necessary to install transmission lines.

\section{Covenant}

When property is sold, restrictions may be placed in a purchaser's deed prohibiting certain uses of the land. A developer who acquires only part of a larger parcel can ask the landowner to agree that when other parcels are sold, the deeds will contain restrictive covenants prohibiting new owners from obstructing the developer's access.

Restrictive covenants that preserve access must be in writing and should be recorded. Recorded covenants bind successive purchasers of land burdened or benefited by covenants.

\section{Permit or License}

The landowner may grant the developer a permit or license to use the land or airspace for a specified time or purpose. This right is generally revocable at the landowner's will and may not be transferred or assigned. The developer who acquires a personal license or permit does not acquire a legal interest in land that can be recorded or mortgaged.

\section{Contract Provisions}

Both the developer seeking access rights and the landowner interested in leasing resources would be wise to invest in competent legal advice. Consultation with a qualified accountant regarding royalty payments and applicable tax laws is also advised. Contracts for a purpose, such as oil and gas leasing, may not be appropriate for geothermal development. The parties should design a contract that meets their specific needs and time requirements of the project.

\section{Idaho State Agencies' Responsibilities}

\section{Agency: Idaho Department of Water Resources (IDWR)} Statutory Authority: Idaho Code, Title $\mathbf{4 2}$

The Idaho legislature designated the Idaho Department of Water Resources (IDWR) as the regulatory agency for the drilling, operation, maintenance, and abandonment of all geothermal wells in the state. Consequently, drilling permits and geothermal permits are obtained through the IDWR.

IDWR also administers the water appropriation permits program. IDWR has several other public service oriented programs that are also applicable to geothermal development including those of the Energy Division. 


\section{Agency: Idaho Department of Water Resources, Energy Division (IDWR) \\ Statutory Authority: Executive Order \#76-4; Executive Order 80-10}

The Idaho Energy Division was created in February 1974. The office originally functioned as part of the Governor's Office. Subsequently, it was transferred to the Public Utilities Commission, but again was transferred back to the Governor's Office by Executive Order 76-4 in 1976.

In 1981, through Executive Order 80-10, the Idaho Office of Energy merged with the Idaho Department of Water Resources. The newly-formed Energy Bureau existed until 1989, at which time it was elevated to division status.

The Energy Division's mission places emphasis on energy conservation activities and the use of renewable resources.

\section{Agency: Idaho Department of Lands (IDL)}

Statutory Authority: Idaho Code, Sections 47-701 et seq., 47-1601 et seq., Title 58

If state land is involved in a proposed geothermal development, either for the power plant, road access, transmission line right-of-way, or pipelines for transporting brine or steam, necessary use permits and leases will need to be negotiated through the Idaho Department of Lands(IDL).

Whenever construction occurs below the mean high water mark of a river or encroaches on other state lands, an easement must be secured through the IDL. A fee is charged dependent on the land's fair market value.

\section{Agency: Idaho Department of Fish and Game (IDFG)}

Statutory Authority: Idaho Code, Title 36

The Idaho Department of Fish and Game (IDFG) is responsible for protecting and enhancing fish and wildlife populations and the habitats necessary to sustain those populations. Discharge of geothermal effluents or brines into natural water courses or wetlands can cause water quality problems such as poor water chemistry, algal blooms, decreased dissolved oxygen content, increased water temperatures, or increased turbidity. The water quality standards set by the Idaho Department of Health and Welfare address these concerns with respect to both fisheries and human needs.

Loss of habitat and interference with migration are other possible impacts of geothermal development. The IDFG may require impact mitigation measures that can affect the design, construction, or operation of a project. 
Agency: Idaho Department of Parks and Recreation (IDPR)

Statutory Authority: Idaho Code, Sections 67-4201 through 67-4301 et seq.

The Idaho Department of Parks and Recreation (IDPR) is responsible for reviewing proposed projects for their positive or negative impacts on recreation. The IDPR can impose conditions to enhance the recreational potential of a stream or adjoining land, or it can impose mitigative measures to lessen adverse impacts.

\section{Agency: Idaho Department of Health and Welfare (IDHW) \\ Statutory Authority: Idaho Code, Section 39-3601 et seq.}

As required by the Clean Water Act and the Clean Air Act, applications for energy project development must obtain certification that the proposed project will not cause any violation of state water or air quality standards. In Idaho, certification can be obtained from the Division of Environmental Quality of the Idaho Department of Health and Welfare (IDHW). Water quality standards-are not the same for all streams in the state and clarification of the appropriate standards should be obtained prior to application. Authorization for temporary violation of water quality standards (as would likely occur during construction) must also be obtained.

It may be advisable for projects involving significant environmental impacts to retain the services of an expert environmental consultant to help in gathering necessary information and in recommending mitigative measures. Agencies themselves also have environmental specialists who can assist in determining what information needs to be collected.

\section{Agency: Idaho State Historic Preservation Office (ISHPO) Statutory Authority: Idaho Code, Sections 67-4101 et seq. and 67-4601 et seq.}

State and federal law protects historical and archaeological sites as well as National Register properties. The Idaho State Historic Preservation Office (ISHPO) has responsibility for reviewing the impacts of proposed projects and any avoidance, mitigation, or protective measures proposed by the applicant. A report on the cultural resources located in the project area must be included in the license or exemption application. Assistance in preparing this report can be obtained from the ISHPO.

\section{Agency: Idaho Public Utilities Commission (IPUC) Statutory Authority: Idaho Code, Title 61}

The Idaho Public Utilities Commission (IPUC) should be contacted during the preparation of an application for several reasons. First, the IPUC has jurisdiction over the prices paid by investorowned utilities for power purchased from electric generation facilities and over the rates and charges levied by investor-owned utilities on generation project developments for interconnection, line maintenance, and the supply of back-up power. Second, the IPUC can help identify the 
utilities that might be possible buyers of new electrical energy. Contracts between a small power producer and a regulated utility must be approved by the IPUC. In addition, the IPUC plays a strong role in energy facility siting.

The IPUC has been very supportive of small power producers and has been an early leader in implementing the Public Utilities Regulatory Policy Act (PURPA). While no standard form contract is enforced, the IPUC has encouraged Idaho utilities to bargain in good faith with small power producers. Recent reformulation of the avoided cost schedule formula which depends only on actual energy output (rather than capacity), recognizes that the value of a kilowatt hour is seasonal in character. The exact payment, which has an upward adjustment factor for contracts in future years, may be crucial to the economic profitability of any renewable energy project.

In Idaho the term "public utility" includes: ... every common carrier, pipeline corporation, gas corporation, electrical corporation, telephone corporation, telegraph corporation, motor corporation, and wharfinger, as those terms are defined in this chapter and each thereof is hereby declared to be a public utility and to be subject to the jurisdiction, control, and regulation of the commissions and to the provisions of the act: provided that the term "public utility" as used in the act shall cover cases both where the service is performed and the commodity delivered directly to the public or some portion thereof, and where the service is performed on the commodity delivered to any corporation or corporations or any person or persons, who in tum, either directly or indirectly or mediately or immediately, perform the services or delivers such commodity to or for the public or some portion thereof (Idaho Code § 61-129).

Public utility regulation also requires a Certificate of Convenience and Necessity (Idaho Code § 61-526).

Before an electrical corporation or water corporation begins constructing a line, plant, or system or extension of same, it must first obtain from the IPUC a certificate that the present or future public convenience and necessity require or will require such construction.

\section{Agency: Idaho Transportation Department (ITD) Statutory Authority: Idaho Code, Title 49}

When a project requires construction of a new road that connects with an existing highway, an approach permit must be obtained from the Idaho Transportation Department (ITD). Some existing roads are not under the jurisdiction of the state and a permit may be required from a local highway district. The ITD can advise about who has jurisdiction. Permits will also be required if a project requires the operation of oversize or overweight vehicles on highways. Permits are also required to place utility facilities in a highway right-of-way. 
Agency: Office of the Secretary of State

Statutory Authority: Idaho Code, Sections 30-1-55, 53-213, and 48-501 et seq.

The office of the Secretary of State handles such items as the filing of Articles of Incorporation/Certificates of Limited Partnerships, and the Registration of Trademarks.

\section{Idaho State Permitting and Licensing Requirements}

\section{Geothermal Development on State and Private Land}

The Idaho Legislature designated the Idaho Department of Water Resources as the regulatory agency for the drilling, operation, maintenance, and abandonment of all geothermal wells in the state. Drilling permits and geothermal permits can be obtained through this office.

Any person who, as owner or operator, proposes to construct or alter a well or an injection well must first apply for a geothermal resource well permit (Idaho Code \$ 42-4003(a)).

If state land is involved in a proposed geothermal development, either for the power plant, road access, transmission line right-of-way, or pipelines for transporting brine or steam, necessary use permits and leases will need to be negotiated through the Department of Lands.

\section{Major Facility Siting/Environmental Impact}

\section{Energy Facility Siting}

Idaho has no facility siting agency, but the Idaho Public Utilities Commission plays a strong role in facility siting.

\section{State Environmental Policy Act (SEPA)}

Idaho does not have anything similar to a State Environmental Policy Act (SEPA) process. Environmental permits are required by various state agencies.

\section{Permit or Regulation: Environmental Reporting/Compliance with the} National Environmental Protection Act (NEPA)

Statutory Authority: 42 United States Code $\mathbf{4 3 2 1}$

Agency: Varies

Because the state of Idaho does not have statewide environmental review requirements, certain projects will require environmental review on the federal level. The federal approvals/permits required for a project that could trigger environmental reporting requirements include federal 
geothermal leasing, the U.S. Corp of Engineers 404 Permit, and in some cases, the National Pollutant Discharge Elimination System Permit (NPDES). Prevention of Significant Deterioration (PSD) permits are exempt for NEPA compliance.

The key issue is whether the proposed federal agency action constitutes a major federal action that significantly affects the quality of the environment. If the action is not significant, the agency may choose to issue a Finding of No Significant Impact (FONSI) in lieu of an EIS. Other options include enclosing an EIS prepared by another federal or state agency on the same project (see the Federal section of this book, pages 9 through 65)).

\section{Air Quality}

\section{Permit or Regulation: Permit to Construct}

Statutory Authority: Idaho Code, Section 39-115

Agency: Idaho Department of Health and Welfare (IDHW)

Any owner/operator of a facility that emits or may emit an air contaminant (dust, fumes, gas, mist, odor, smoke, vapor, pollen, soot, carbon, or particulated matter) must apply for a Permit to Construct. Some exclusions are available and include:

- fuel burning equipped for indirect heating and for heating and reheating furnaces using gas exclusively with a capacity of less than $\mathbf{5 0}$ million Btu per hour input

- other fuel burning equipment for indirect heating with a capacity of less than 1 million Btu per hour input

- mobile internal combustion engines

- pilot plants, with written approval from the Administrator renewable annually, the products from which are not offered for sale except in developmental quantities

There are several levels of air quality permitting that are handled in the single permit application process. Not all of these will be applicable to every application. These include:

- Non-Attainment Area Review

- New Source Performance Standards (NSPS)

- National Emission Standards for Hazardous Air Pollutants (NESHAPS)

- Prevention of Significant Deterioration (PSD)

- State Regulations, including Operating Permit

\section{Prevention of Significant Deterioration}

Prevention of Significant Deterioration (PSD) permitting is required for all developments defined as a "major facility." Major facilities include, but are not limited to, any designated stationary source of air pollution emitting or having the potential to emit 100 tons or more per year of any pollutant subject to regulations. Such facilities include: 
- combined fossil and biomass boilers totaling more than 250 million Btu per hour heat input

- fuel conversion plants

- municipal incinerators capable of charging more than 250 tons of refuse per day

Also defined as major facilities are any other stationary sources that emit or have the potential to emit 250 tons per year of any pollutant subject to regulation.

An additional consideration in the PSD evaluation process is necessary if the facility will be constructed in or near a Class I area. Different air quality standards will apply in such a case, and the federal land manager responsible for the Class I area (e.g., U.S. Forest Service, National Park Service) will be involved in the permitting process.

\section{Non-Attainment Area Review}

Non-Attainment Area Review is applicable only to those facilities proposed to be located in an EPA designated non-attainment area of the state. There are three such areas:

- Ada County (Boise) for carbon monoxide (CO)

- Don Siding (Pocatello) for total suspended particulates (TSP)

- Conda (Soda Springs) for total suspended particulates (TSP)

Non-Attainment Area Review requires that four conditions be met, at least one of which will be outside the applicant's control.

- enforcement of an approved State Implementation Plan (SIP) containing growth provisions pertinent to the Non-Attainment area

- application of Lowest Achievable Emission Rates to the proposed facility

- compliance of all sources owned by the applicant that are located in the state with appreciable air emission regulation

- emission offsets (reduction in emission already occurring in the area) if at least 120 percent and demonstrated commensurate improvement in air quality

\section{New Source Performance Standards}

Review is the most straight-forward of the evaluations since it requires a comparison of projected potential emissions from the new facility with an established emission standard for the particular type of facility.

In PSD permitting, location of the facility, topography, and meteorology of the area are extremely important because they help determine the applicable increment of allowable air quality deterioration.

If adequate data on background levels are not already available, which is usually the case, air quality monitoring by the applicant for up to one year may be required. 
Emission control technology to be used on the facility must conform to the Best Available Control Technology (BACT) as determined on a case-by-case analysis. Allowable pollution increments for Idaho are given in Table 4.

The Idaho Department of Health and Welfare, Air Quality Bureau provides a standard application form for all air quality permits.

Information is required about the applicant; the proposed project; facilities operating within the state owned by the applicant; fuel burning equipment; estimated emissions; producing and manufacturing operations; refuse disposal and incineration, storage, handling, and use of volatile organic compounds; loading racks and oil-water separators; hazardous/toxic materials; and material transport and handling.

If PSD regulations are applicable, data on baseline air quality conditions must be provided. If PSD compliance is necessary, monitoring of baseline (existing) air quality conditions in the project area for up to a year may have to be carried out.

New Source Performance Standards applicability includes, but is not limited to:

- electric utility steam generating units with a heat input greater than 250 million Btu/hour of fossil fuel alone or in combination with any other fuel

- $\quad$ storage vessels for petroleum liquids with a capacity greater than 40,000 gallons

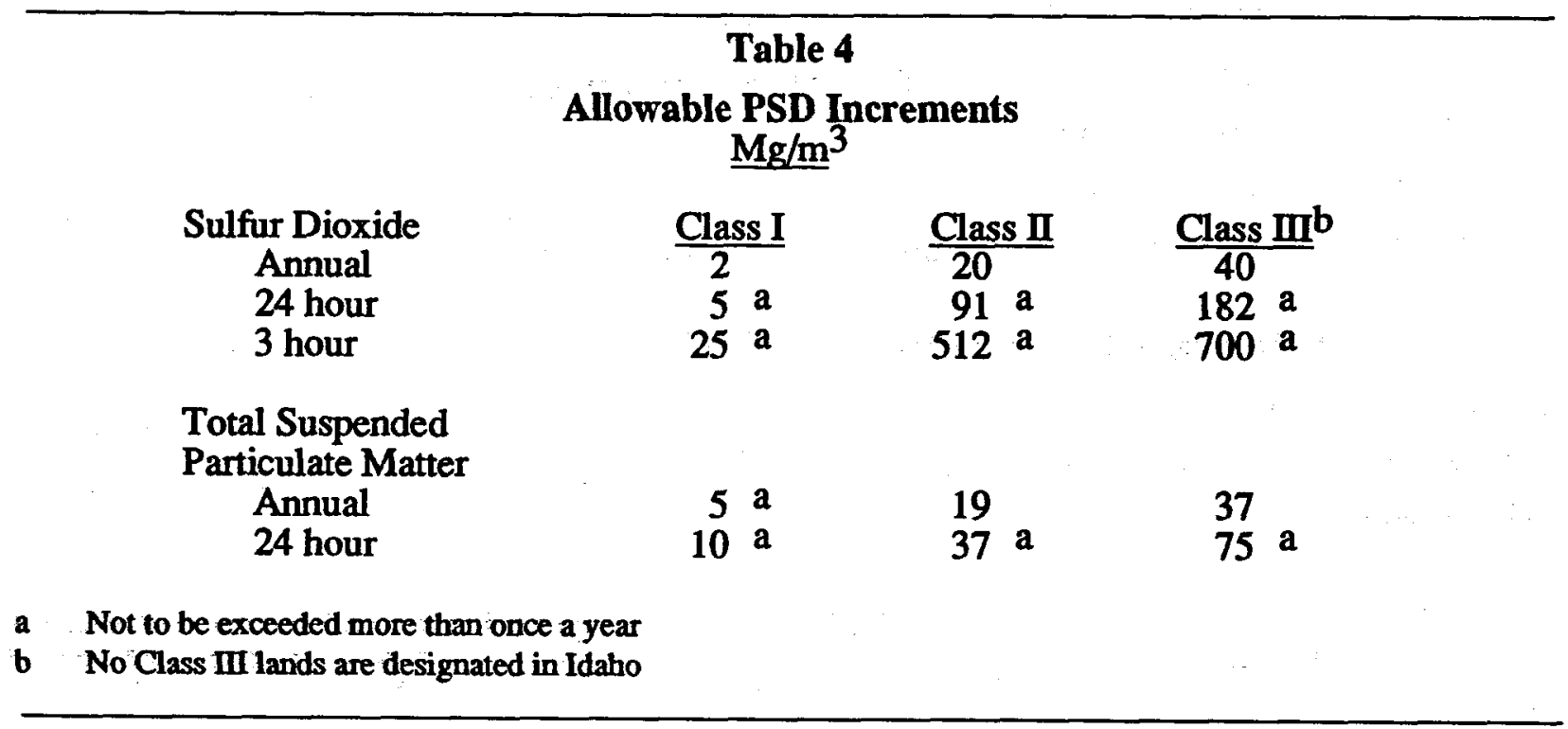


National Emission Standards for Hazardous Air Pollutants (NESHAPS) apply at present only to facilities handling:

- asbestos

- beryllium

- mercury

- vinyl chloride

\section{Approximate Time for Permit Process}

Once an application for a Permit to Construct is received, the Department has 30 days to review for completeness. Once an application is accepted as complete, the Department has 60 days in which to evaluate the application before notifying the applicant of its decision to approve or deny the permit. In the case of facilities that would cause substantial air quality impacts or affect a Class I area, a 30-day period for public comment following notice must be provided before a determination is made.

\section{Water Quality/Water Use}

\section{Permit or Regulation: Low Temperature Geothermal Resource Appropriation Statutory Authority: Idaho Code Section 42-233 Agency: Idaho Department of Water Resources (IDWR)}

The right to the use of low temperature geothermal resources of Idaho must be acquired by appropriation. The appropriation may be perfected by means of the application, permit; and license procedure as provided for groundwater, provided that low temperature geothermal resources be utilized primarily for heat value and secondarily for the value as water. Usage of a low temperature geothermal resource primarily for reasons other than heat value is not considered a beneficial use of the resource, unless the Director of the Idaho Department of Water Resources (IDWR) exempts the proposed use. The Director may exempt a proposed use if the proposed use satisfies the following criteria: (1) there is no feasible alternate use of the resource; (2) there is no economically viable source of water having a bottom hole temperature of $85^{\circ} \mathrm{F}$ or less in a well available; and (3) the exemption is in the public interest.

Any owner of a well who engages in the drilling, redrilling, modifying, or deepening of any low temperature geothermal well must file with the Director of the IDWR a surety bond or cash bond in the penal sum of not less than $\$ 5,000$ or more than $\$ 20,000$ as determined by the Director of the Idaho Department of Water Resources based on the temperature, depth, and pressure of the resource, the size and depth of the well, and any other relevant factors. The surety or cash bond must be conditioned upon the proper compliance with the provisions of chapter 40 , title 42 , and Idaho Code, and rules and regulations promulgated pursuant to chapter 40 . The bond shall remain in effect for 1 year following completion of drilling, redrilling, modifying, or deepening of the well or until released in writing by the Director, whichever occurs first.

All permits, licenses, decreed rights, and valid claims to a right to the use of groundwater which would be classified as a low temperature geothermal resource having a priority date prior to July 1,1987 , remain valid and the bond provisions are not applicable unless the well from which the right diverts water is modified or deepened. The provisions of this section are not applicable to 
all permits, licenses, and rights to the use of geothermal resources as defined in chapter 40 , title 42, Idaho Code, which would be classified as a low temperature geothermal resource issued or proclaimed prior to July 1,1987 , and the bond provisions of are not applicable to such wells.

\section{Permit or Regulation: Public Water Supply Statutory Authority: Idaho Code Section $39-118$ Agency: Idaho Department of Health and Welfare (IDHW)}

The Idaho Department of Health and Welfare (IDHW) requires that plans and specifications for the construction of any new, modified, or expanded drinking water systems must be approved by the Division of Environmental Quality (DEQ). This includes piping that delivers water for consumption by 10 or more premises or 25 or more people for at least 60 days a year (or other systems designated by the Director or having a public health significance). Developers of smaller water systems should contact their local District Health Department.

Plans and specifications submitted to the IDHW must be prepared and certified by a professional engineer licensed to practice in Idaho. When the construction is complete, certified as-built plans must also be submitted to the IDHW. In lieu of as-built plans, the engineer of record may certify that the facility was constructed according to the approved plans. To achieve that requirement, the engineer of record must be hired to inspect the project while it is being constructed. If the engineer is not hired, or is released from the job, the engineer is required to inform DEQ.

The purpose of engineering reviews is to ensure that public health and water quality are protected by using accepted construction practices and materials. Water quality engineers make every reasonable effort to complete reviews as promptly as possible, generally within 30 to $\mathbf{4 5}$ days. Reviews are scheduled on a first come-first served basis.

\section{Permit or Regulation: Water Appropriation \\ Statutory Authority: Idaho Code, Section 42-202-42-222 Agency: Idaho Department of Water Resources (IDWR)}

A water right allows use of a certain amount of ground or surface water for a specified use during a definite time period. The permit sets a priority or time of the title-holder's first application for water. A water right for power purposes according to Idaho law (Section 42-202 of the Idaho Code) can be initiated only by filing an application for a permit to divert (or use) ground or surface water.

Once the Idaho Department of Water Resources (IDWR) approves an application, a permit is issued and use of the water can begin. The permit holder has up to 5 years to develop the water resource and complete the project. At the end of the development period, the permit holder must submit proof of beneficial use or, if the project is partially completed, extension of time for an additional 5 years can be requested. IDWR may issue a license for the water right. 
A properly filled out application form submitted with a required fee starts the water right permit process. IDWR supplies application forms and assistance in completing the form. The fee required varies with the rate of flow requested. Certain project details and costs and a financial statement from the applicant may also be required.

Upon acceptance of the proper form and fee, IDWR will advertise the application as a legal notice. The legal notice will be published for 2 consecutive weeks in a generally distributed newspaper in the county to notify residents of the area of the possible increased use of water in their area. At this point, a protest against the approval of the advertised permit may be filed with IDWR by area residents. If water users or other affected people believe that a new appropriation of water may injure their prior water rights or other interests, they may file a protest with IDWR within 10 days of the last date of publication of the legal notice advertising the new application.

IDWR always attempts to resolve the differences between parties by means of an informal conference and finds that most protests can be settled in this manner. If the issues cannot be resolved during the conference, IDWR may take testimony in a formal hearing format. In that case, information as required by rule 4,5,3 of IDWR's rules and regulations for water appropriation must be submitted.

Five criteria, specified in Section 42-203 of the Idaho Code, must be evaluated by the Director of the IDWR before making a decision on any application (whether protested or unprotested). The five criteria are:

1. the quantity of water available under existing water rights will not be reduced

2. the water supply is sufficient for the purpose for which it is being appropriated

3. application is made in good faith and not for delay or speculative purposes

4. an applicant has sufficient financial resources with which to complete proposed work

5. a project will not conflict with the local public interest (the local public interest is defined as the "affairs of the people in the area directly affected by the proposed use")

An application for a permit may be approved, approved with conditions, or denied. The Director's decision may be appealed to the district court by any dissatisfied party.

The issuance of a permit allows the permit-holder to start the construction that will put the water appropriated to a beneficial use. A permit is issued for a maximum development period of 5 years with the possibility of one extension of time of up to 5 years to complete a project. If delayed by legal action, it is possible to get additional extensions. Within the permit period, the permit-holder must complete the construction of the planned project and put the water to a beneficial use. If this does not occur within the permit period, the permit may lapse. When the project is completed, the permit-holder must file proof of beneficial use along with the required examination fee. IDWR will then inspect the use of the water and issue a license. 
In order to protect groundwater resources (including geothermal resources) from over exploitation, Idaho law allows for two area designations that limit groundwater appropriation within a designated area.

(A) "Critical groundwater area" is defined as any groundwater basin or designated part thereof, not having sufficient groundwater to provide a reasonably safe supply for irrigation of cultivated lands, or other uses in the basin at the then current rates of withdrawal, or rates of withdrawal projected by consideration of valid and outstanding applications and permits (Idaho Code § 42-233a).

If an application for permit is made in an area that has been designated as a critical groundwater area, the Director of IDWR may deny the application if he believes that there is insufficient water available subject to appropriation at the location of the proposed well described in the application. This belief may come from the investigation of the application, or from investigation made in determining the area to be critical, or from other information that has officially come to his attention. If groundwater at the location is available in a lesser amount than that applied for, the Director of IDWR may issue a permit for the use of the water to the extent that the water is available for appropriation.

(B) A "groundwater management area" is a groundwater basin that the Director of the IDWR declares is approaching the condition of a critical groundwater area. The critical groundwater area designation may be used to justify denial of a groundwater permit for geothermal development (Idaho Code § 42-233b).

Application for permits made within a groundwater management area are approved by the Director only after he has determined on an individual basis that sufficient water is available and that other prior water rights will not be injured.

Upon determination that the groundwater supply is insufficient to meet the demands of water rights within all or portions of a water management area, those water right holders will be ordered on a time priority basis, within the area determined by the Director, to cease or reduce withdrawal of water until the Director determines there is sufficient groundwater.

\section{Permit or Regulation: Compliance with the Idaho Comprehensive State Water Plan Statutory Authority: Idaho Code Section 42-1734 et.seq. Agency: Water Resource Board (Board)}

The comprehensive state water plan's purpose is to plan for conservation, development, management, and optimum use of all unappropriated water resources and waterways of the state in the public interest. The plan contains a description of existing and planned uses and the impact of 
such uses at the local, state, and regional level. The plan quantifies, insofar as possible, the unappropriated waters of the planning area and plans the allocation of such waters among the various competing uses.

As part of the plan, selected waterways have been designated as protected rivers. Protected rivers can be either a natural or a recreational river. A natural river is a waterway which possesses outstanding fish and wildlife, recreation, geologic, or aesthetic values. The waterway is free of substantial man-made impoundments, dams, or other structures and of which the riparian areas are largely undeveloped, although accessible in places by trails and roads. A recreational river is similar to a natural river except that it might include some man-made development within the waterway or within the riparian area of the waterway.

Proposed projects would be evaluated for their effect on fish and wildlife, recreational, aesthetic, historical, cultural, natural, or geologic values of the waterway. For rivers designated as natural, the following activities are prohibited:

- construction or expansion of dams or impoundments

- construction of hydropower projects

- construction of water diversion works

- dredge or placer mining

- alterations of the stream bed

- mineral or sand and gravel extraction within the stream bed

In designating a recreational river, the Water Resource Board (Board) will determine which of the activities listed above shall be prohibited and may specify the terms and conditions under which activities that are not prohibited may go forward.

Review for compliance with the comprehensive state water plan is triggered by filing a water rights application. If a proposed project has some potential for conflict with the plan in the opinion of the Director, he can recommend review by the Board.

\section{Approximate Time Required for Processing}

Since review is concurrent with review of a water appropriation permit, processing time can vary depending upon whether protests are filed against the permit application. Because the plan is more restrictive with regard to natural rivers, processing should be relatively quick. However, since the Board may need to develop terms and conditions for projects on recreational rivers, processing times will be longer.

\section{Permit or Regulation: Compliance with the Idaho State Water Plan}

Statutory Authority: Idaho Constitution Article 15, Section 7, Idaho Code Section 42-1831 Agency: Water Resource Board (Board)

Anyone wishing to use surface waters or groundwaters for beneficial purposes is required to obtain a water right. In order for a water right to be granted, the proposed use must be in compli- 
ance with the Idaho State Water Plan. The purpose of the plan is to guide the development, management, and use of the state's water and related lands. The plan states the objectives of the Water Resource Board (Board) and establishes policies which will guide future water usage. In most cases, the policies are not specific enough to directly relate to individual projects that may be proposed. However, minimum streamflows are established for the Snake River which could directly affect proposed projects.

These reviews are to ensure that future water resource uses will complement and supplement' state goals directed toward achieving a quality of life for the citizens of Idaho. The plan recognizes past actions, addresses present conflicts, and identifies future opportunities.

Review by the Water Resource Board is triggered by making application to appropriate water. If a proposed project has some potential for conflict with the state water plan in the opinion of the Director, he can recommend review by the Board.

\section{Approximate Time Required for Processing}

The time required for processing will usually be commensurate with the scope of the project being proposed. Small projects generally will not require review for compliance with the water plan. The review process for a major project, however, could take several months.

\section{Permit or Regulation: Drilling Permit Statutory Authority: Idaho Code, Section 42-238(4) Agency: Idaho Department of Water Resources (IDWR)}

The owner of a well to be constructed, drilled, deepened, or enlarged shall obtain a drilling permit from the Idaho Department of Water Resources (IDWR) prior to constructing or drilling of the well. The drilling permit can be issued to the owner of the proposed well, the driller employed to construct the well, or to the owner's representative.

The drilling permit does not constitute a water right permit, injection well permit, or other authorization which may be required from IDWR prior to actual well construction and does not authorize use of water from the well or discharge of fluids into the well.

Geotechnical borings for the purpose of mineral exploration or the design of foundations for structures or for the design of dams and embankments are not subject to drilling permit requirements but must be constructed and abandoned in accordance with minimum well construction standards.

\section{Approximate Time Required for Processing}

Approximate time to obtain a.Drilling Permit is 6 to 8 weeks. The drilling permit will be issued at the same time as a water appropriation permit is issued. 
Permit or Regulation: Mrilling for Geothermal Resources

Statutory Authority: Idaho Code, Sections 42-4001 through 42-4015

Agency: Idaho Department of Water Resources (IDWR)

Any person who, as owner or operator, proposes to construct or alter a well or an injection well must first apply to the Director of the Idaho Department of Water Resources (IDWR) for a geothermal resource well permit (Idaho Code \$ 42-4003(a)).

No person can construct or alter a well or an injection well without having first secured a permit. However, the Director of IDWR may, by general rule or regulation adopted pursuant to chapter 52 , title 67, Idaho Code, exempt specific categories of wells or injection wells upon a finding that the purposes of this act do not require that such wells be subject to the permit requirement of this section (Idaho Code \$ 42-4003(d)).

The Director of IDWR has the authority to and may designate any area of the state a "geothermal area" when he finds or has reason to believe that such designation is necessary to protect the geothermal resource from waste and to protect other resources of the state from contamination or waste (Idaho Code \& 42-4003(f)).

No person can drill a well for any purpose to a depth of 3,000 feet or more below land surface in a designated "geothermal area" without first obtaining a permit. These permits are in addition to any permits required by Idaho Code $\$ 42-4003(\mathrm{~g})$.

The owner of any well constructed or being constructed pursuant to section 47-320, Idaho Code, who encounters a geothermal resource and who intends or desires to utilize the resource, must apply for a geothermal permit. However, no additional filing fee will be required (Idaho Code 42-4003(h)).

\section{Approximate Time Required for Processing}

Approximate time for processing an application is 6 to 8 weeks. The geothermal drilling permit will be issued at the same time as a water appropriation permit is issued.

\section{Bonds}

As a condition of every permit, the Director of IDWR requires every operator or owner who engages in the construction, alteration, testing, or operation of a well to file with the Director on Form $\mathbf{4 0 0 5}$ a bond indemnifying the State of Idaho providing good and sufficient security conditioned upon the performance of the duties regioned by the regulations and the Geothermal Resource Act and the proper abandonment of any well covered by such permit. The bond must be for not less than $\$ 5,000$ for each individual well.

\section{Processing of Applications, Investigating, Hearings}

In approving or denying a permit for the development of a geothermal resource, the Director of the IDWR must determine if well construction or alternative is in the public interest. In making this determination, the Director considers: 
- The adequacy of measures proposed to safeguard subsurface, surface, and atmospheric resources from unreasonable degradation, and especially to protect groundwater aquifers and surface-water sources from contamination which would render such water of lesser quality than it would have had but for the contamination.

- The possibility that the construction and maintenance of the proposed well will cause waste or will damage any geothermal resource, reservoir, or other source, by unreasonable reduction of pressures or unreasonable reduction of any geothermal resource material medium or in any other manner, so as to render any other resource of unieasonably less value.

- The adequacy of measures proposed to safeguard the environment of the area around the site of the proposed well from unreasonable contamination or pollution.

- Any possible interdependence between any geothermal resource, reservoir, pool, or other source expected to be affected under the permit and any aquifers or other sources of groundwaters used for beneficial uses other than uses as a material medium or a mineral source, and the probability that such interdependence may cause such groundwater sources to be inadequate to meet demands on them under existing water rights (Idaho Code $\S 42$ 4004(b),(2)(3)(4)(5)).

\section{Powers and Duties - Penalties}

The Water Resource Board may adopt, amend, or rescind reasonable rules, regulations, and construction standards necessary to the administration in accordance with chapter 52 , title 67 , Idaho Code. Regulations adopted pursuant hereto may be interpretative of provisions of this act.

The Board may require that owners or operators of wells or injection wells keep or cause to be kept well logs, core records, and drilling histories of such wells or injection wells. It may require that copies of such logs, records, and/or histories be filed with the Director within a reasonable time after well completion. It may further require such other geologic, geochemical, or engineering plans, reports, or records as necessary for the administration of this act. Any reports, logs, records, or histories filed with the director are not available for public inspection and are kept as confidential by the Director for a period of 1 year from well completion, provided, however, that the Director may use any such reports, logs, records, or histories in any action in any court to enforce the provisions of this act or any order or regulation adopted (Idaho Code, $\$ 42-4010(6)$ ).

\section{Well Abandonment or Discontinuance of Operation - Notice}

At least 5 days before any operation to abandon any well or injection well is commenced, the owner or operator of any well or injection well must submit in writing a notification of intention to abandon to the Director for approval, except that it shall be permissible to give oral notice followed within 24 hours by written confirmation. Notification must clearly state the condition of 
the well or injection well, and the proposed method of abandonment. No person may commence any operation to abandon a well or an injection well without approval by the Director (Idaho Code, § 42-4007).

\section{Permit or Regulation: Well Abandonment or Discontinuance of Operation - Notice Statutory Authority: Idaho Code, Sections 42-4007 through 42-4009}

Agency: Idaho Department of Water Resources (IDWR)

The objectives of abandonment are to block interzonal migration of fluids to:

1. prevent contamination of fresh water or other natural resources

2. prevent damage to geothermal reservoirs

3. prevent loss of reservoir energy

4. protect life, health, environment and property

At least 5 days before starting any operation to abandon any well or injection well, the owner or operator must submit in writing a notification of intention to abandon to the Director of the Idaho Department of Water Resources (IDWR) for approval. It is permissible to give oral notice followed within 24 hours by written confirmation. Notification must clearly state the condition of the well or injection well, and the proposed method of abandonment. It is not permissible to start any operation to abandon a well or an injection well without approval by the Director of IDWR.

\section{Processing of Applications, Investigating, Hearings}

In approving or denying a permit for the development of a geothermal resource, the Director of the IDWR must determine if well construction or an alternative is in the public interest. In making this determination, the Director considers:

- The adequacy of measures proposed to safeguard subsurface, surface, and atmospheric resources from unreasonable degradation, and especially to protect groundwater aquifers and surface water sources from contamination that would render such water of lesser quality than it would have had but for the contamination.

- The possibility that the construction and maintenance of the proposed well will cause waste or will damage any geothermal resource, reservoir, or other source, by unreasonable reduction of pressures or unreasonable reduction of any geothermal resource material medium or in any other manner, so as to render any other resource of unreasonably less value.

- The adequacy of measures proposed to safeguard the environment of the area around the site of the proposed well from unreasonable contamination or pollution.

- Any possible interdependence between any geothermal resource, reservoir, pool, or other source expected to be affected under the permit and any aquifers or other sources of groundwaters used for beneficial uses other than uses as a material medium or a mineral source, 
and the probability that such interdependence may cause such groundwater sources to be inadequate to meet demands on them under existing water rights (Idaho Code 42-4004(b), $(2)(3)(4)(5))$.

\section{Powers and Duties - Penalties}

The Water Resource Board may adopt, amend, or rescind reasonable rules, regulations, and construction standards necessary to the administration of this act in accordance with chapter 52 , title 67, Idaho Code. Future regulations adopted may be interpretative of provisions of this act.

The Board may require that owners or operators of wells or injection wells keep or cause to be kept well logs, core records, and drilling histories of such wells or injection wells. It may require that copies of such logs, records, and/or histories be filed with the Director of IDWR within a reasonable time after well completion. It may further require such other geologic, geochemical, or engineering plans, reports, or records as necessary for the administration of this act. Any reports, logs, records, or histories filed with the Director of IDWR will not be available for public inspection and shall be kept as confidential by the Director of IDWR for a period of 1 year from well completion. However, the Director of IDWR may use any such reports, logs, records, or histories in any action in any court to enforce the provisions of this act or any order or regulation adopted hereunder (Idaho Code $\$ 42-4010(\mathrm{~b})$ ).

\section{Permit or Regulation: Injection Wells}

Statutory Authority: Idaho Code Sections 42-3913 through 42-3915

Agency: Idaho Department of Water Resources (IDWR)

All deep injection wells must be authorized by permit. A permit is required for the operation or modification of an existing well or the construction of a new well.

The owner or operator of a proposed injection well or series of injection wells must provide information necessary to evaluate the impact of such injection on the geothermal reservoir and other natural resources. Information should include existing reservoir conditions, methods of injection, source of injection fluid, estimates of daily amounts of material medium to be injected, zones or formations affected, and analysis of fluid to be injected and of the fluid from the intended zone of the injection. This information must be provided on IDWR Form 4003-3.

\section{Approximate Time Required for Processing}

Approximate time to obtain this permit is 6 to 8 weeks. 


\section{Land Use}

\section{Permit or Regulation: Geothermal Leases on State Land}

Statutory Authority: Idaho Code Title 47, Chapter 16; Title 67, Chapter 52

Agency: Idaho Department of Lands (IDL)

A completed application for geothermal resources lease must be submitted to the Idaho Department of Lands (IDL). Applications for a geothermal resource lease are considered in the order in which they are filed. Should two or more applications be received on the same day for the same site, they will be considered as simultaneous filings. (See page 69 for further information on geothermal leases on state lands).

\section{Permit or Regulation: Cooperative Unit Agreements - Voluntary - Involuntary} Statutory Authority: Idaho Code, Sections 42-4013(a)(b)

Agency: Idaho Department of Water Resources (IDWR)

Whenever the Director of the Idaho Department of Water Resources (IDWR) finds that it is in the public interest and especially in the interest of the conservation of natural resources and of the protection of the geothermal resources from waste, he may allow special agreements. The lessors, lessees, operators, owners, or other persons holding or controlling royalty or other interests in the separate properties of the same geothermal area may, with the approval of the Board, enter into an agreement to: bring about the cooperative development, operation, and maintenance of all or a portion of the geothermal resources of the geothermal area as a unit or fix the time, location, and manner of drilling, operating, and maintaining of wells and of injection wells. These agreements will bind the successors, and will be enforceable by the parties by an action for specific performance. No agreements, when approved by the Board, will be held to violate any of the statutes of the state prohibiting monopolies or acts, arrangements, agreements, contracts, combinations, or conspiracies in restraint of trade or commerce. No agreement authorization will constitute a waiver of any permit, license, lease, or other authorization required under any provision of state law or any regulation adopted by any agency or subdivision of the state. The Board may establish procedures to govern the establishment or adoption of such cooperative unit agreements.

Whenever the Director of IDWR finds that a geothermal resource area should be cooperatively operated as a unit to avoid waste, and the persons owning tracts or interests in such area refuse to enter into a cooperative agreement, the Board, after notice and hearing, may issue an order that such area shall be operated as a unit. This order will provide an equitable sharing of proceeds and liabilities from the geothermal resource area among the several owners of tracts and interests therein.

\section{Approximate Time Required for Processing}

Approximate time for approving a unitization agreement is 6 weeks. 
Permit or Regulation: Floodplain Development

Statutory Authority: National Flood Insurance Act of 1968; Flood Disaster Protection Act of 1973; Local County and City Ordinances

Agency: Idaho Department of Water Resources (IDWR); Local Governments

The appropriate local authority will review all plans to ensure that any changes proposed or structure to be constructed will not have an adverse effect upon flooding. One key element is that the capacity of streams cannot be changed.

Approximate Time Required for Processing

Permits will generally be approved within 6 weeks.

\section{Permit or Regulation: Historical Site Permit}

Statutory Authority: Section 106 of the National Historic Preservation Act of 1966;

36 CFR 800 "Procedure for the Protection of Historic and Cultural Properties" Agency: Idaho State Historic Preservation Office (ISHPO)

After being notified of a proposed project, the Idaho State Historic Preservation Office (ISHPO) will check inventory and survey records to determine if surveys have been conducted and whether archaeological sites on historic properties have been identified in the project area.

In some cases, professionals from the ISHPO will inspect a project area to help a private firm or individual comply with federal preservation laws. If a proposed project requiring federal approval or a federal license is not on federal land, is not federally funded, and if it is less than 25 acres in size, the ISHPO will consider inspecting the project at no cost to the applicant.

\section{Idaho Procedures for Review of Federal Projects}

After receiving a notification of a project, the ISHPO will check inventory and survey records to determine if surveys have been conducted and whether archaeological sites or historic properties have been identified in the project area.

Based on the nature of the project and on the project's location, the ISHPO will usually make one of the following comments (these comments technically are addressed to the federal agency, even though in some cases the federal agency requires private individuals to obtain ISHPO comments):

1. Archaeological and historic surveys have determined there are no archaeological or historic properties in the proposed area. The project will have no effect.

2. Based on the nature of the project and its location, it is unlikely the project will affect archaeological or historic properties. However, if archaeological materials (arrow points, bottles, etc.) are found during construction, the ISHPO should be contacted. 
3. Based on the nature of the project and its location, it is likely, but not confirmed, that National Register properties occur in the project area and could be affected by the project. The agency should have the area inspected by a professional archaeologist, historian, or architectural historian, as appropriate, to locate and evaluate any archaeological sites and historic properties in the area. This work should follow the Secretary of Interior's guidelines for historic preservation projects.

4. There has been a survey in the area, and archaeological sites or historic properties have been recorded. Following National Park Service standards, the agency should determine which sites or properties are eligible for the National Register.

5. National Register properties will be adversely affected by the project, and the agency should obtain the comments of the Advisory Council on Historic Preservation.

In some cases, professionals from the ISHPO will inspect a project area to help a private firm or individual comply with federal preservation laws. If a project requiring federal approval or a federal license is not on federal land, is not federally funded, and if it is less than 25 acres in size the ISHPO will consider inspecting the project at no cost to the applicant. The decision depends on available personnel and funding.

The ISHPO maintains a log of the projects reviewed and the comments made.

Approximate Time Required for Processing

Normally 30 days is allowed for the SHPO to comment on federal projects. If the SHPO has not commented in this period, the agency can proceed with the Section 106 process. Allowances are made in cases where the normal review period would cause a delay in a project.

\section{Permit or Regulation: State Land Easement \\ Statutory Authority: Idaho Code, Title 58 Agency: Idaho Department of Lands (IDL)}

Whenever construction occurs below the mean high water mark of a river or encroaches on other state lands, an easement must be secured. A fee is charged based on the land's fair market value.

\section{Approximate Time Required for Processing}

Approximate time to process the permit application is several days to several weeks, depending on the complexity of the project. 


\section{Construction}

Permit or Regulation: Highway Encroachment Easements

Statutory Authority: State of Idaho Right-of-Way Use Policy 12-450, 12-451

Agency: Idaho Transportation Department (ITD)

Any person or agency planning to access a highway or use a highway right-of-way for any purpose other than travel, must obtain an approved "Application and Permit to Use Right-of-Way."

A sketch should be provided by the applicant showing the location of existing and proposed approach changes, location of other proposed work to be done within the highway right-of-way, and highway signs in the area of the approach, as well as the costs of studies or appraisals when large development plans must be reviewed and/or extensive Idaho Transportation Department (ITD) time is expected on a traffic study or review. The ITD may require reimbursement for inspection time and travel costs. The intent is to recover ITD cost only. Application will not be processed before payment of the nonrefundable application fee.

The ITD reserves the right to make any changes, additions, repairs, or relocation to any approach or its appurtenances within the highway right-of-way necessary relocation, reconstruction, widening, or maintenance of the highway and/or to provide proper protection of life and property on, or adjacent to, the highway.

Approximate Time Required for Processing

Application for highway encroachment easements can take several days to several weeks to process, depending upon the complexity of the project.

\section{Permit or Regulation: Highway Utility Easements}

Statutory Authority: Idaho Code, Sections 40-312(3), 62-701, 62-705, 62-1101, 42-3212 Agency: Transportation Board; Idaho Transportation Department (ITD)

Highway utility easements relate to the manner in which utility installations are to be made within the right-of-way of state highways when such use and occupancy of the highway right-of-way is deemed to be in the public interest, and will not adversely affect the highway or its users.

Utilities must be located to minimize the need for adjustments for future highway improvements., avoid interference with highway maintenance or signing, and permit access to the utilities for their maintenance with minimum interference to highway traffic.

The utility company or independent power developer is responsible for the design of the utility facility to be installed within the highway right-of-way or attached to a highway structure. The Idaho Transportation Department (ITD) is responsible for review and approval of the proposal with respect to the location of the utility facilities to be installed and the manner of attachment. 
This includes the measures to be taken to preserve the safe and free flow of traffic, structural integrity of the roadway or highway structure, ease of highway maintenance, appearance of the highway, and the integrity of the utility facility.

Facilities located on or across highways for which deeds of right-of-way have not been obtained (such as through National Forest System lands, U.S. Bureau of Land Management land, etc.) shall require a grant of right-of-way for non-highway purposes from the appropriate governmental agency having administration of the lands.

Facilities located on or across highways which are located on railroad property will require the approval of the railroad company.

Each new utility installation which is to occupy highway right-of-way requires a permit. The permit must, as a minimum, describe the ITD standards for location, construction, protection of traffic, maintenance, access restrictions, and any special conditions applicable to each installation.

The permit application must include detailed drawings or sketches showing the location of the proposed facility with respect to existing and/or planned highway improvements, the traveled way, horizontal and vertical clearance, the right-of-way lines and, where applicable, the access control lines and approved access points. When attachment to a highway structure is proposed, details of the attachment method must be included for approval by the ITD prior to installation. The permit application must also include traffic control plans for any work to be performed within the highway right-of-way.

When a proposed facility involves a pipeline carrying potentially hazardous materials, the following additional data are required:

1. contents to be transported

2. pipe size, nominal

3. wall thickness

4. location class and construction type

5. design pressure (maximum operation pressure)

6. maximum actual working pressure

When indicated on the permit, the permittee must take out and maintain property damage and public liability insurance. The permittee may also be required to furnish a surety bond in the amount specified in the special provisions of the permit for installation and future repair, relocation, or removal of the facilities. 
Permit or Regulation: Approval of Wastewater Treatment System and

Subsurface Disposal System

Statutory Authority: Idaho Code, Section 39-118

Agency: Idaho Department of Health and Welfare (IDHW)

All above-ground wastewater treatment systems must be approved by the Idaho Department of Health and Welfare (IDHW). Subsurface systems, except for injection wells, must be approved by the appropriate district offices.

Plans for above-ground treatment systems must be submitted to the appropriate field office of IDHW. For a subsurface disposal system, the legal description of the property, information regarding the amount of water to be used, a plot plan of the proposed layout, and a description of soil types must be submitted.

\section{Approximate Time Required for Processing}

For above-ground systems, IDHW engineers will review and approve or request modification of the plans within a 30-day period. Subsurface systems will generally be reviewed and approved or directed to be modified at the time the application is submitted.

\section{Permit or Regulation: Building}

Statutory Authority: Idaho Code, Title 39, Chapter 41

Agency: Idaho Department of Labor and Industrial Services (ILIS)

The issuance of a building permit is based on the compliance of proposed plans with adopted building codes. In some counties, the building permit is administered by the Idaho Department of Labor and Industrial Services (ILIS).

Approximate Time Required for Processing

Issuance of a building permit for industrial use can be expected to take several weeks after submittal of the building plans.

\section{Permit or Regulation: Mechanical/Plumbing/Electrical Permits Statutory Authority: Idaho Code, Title 39, Chapter 27; Idaho Code, Title 54, Chapter 10 Agency: Idaho Department of Labor and Industrial Services (ILIS)}

Mechanical, plumbing, and electrical permits are based on compliance with state codes and are administered by the state Idaho Department of Labor and Industrial Services (ILIS). The permits are issued directly to the contractor rather than to the owner/operator of the facility being constructed.

Approximate Time Required for Processing Issuance of these permits should not take longer than 2 weeks after submittal of the completed application. 
Permit or Regulation: Non-navigational or Commercial Navigational Encroachments Statutory Authority: Idaliv Code, Section 58-1306

Agency: Board of Land Commissioners (Board)

Applications for construction, enlargement, or replacement of a non-navigational or a commercial navigational encroachment must be submitted on a form furnished by the Board of Land Commissioners (Board) and accompanied by plans of the proposed encroachment containing information required by Sections 58-1113(k) and 1302(b) Idaho Code, and such other information as the Board may, by rules or regulations require, in conformance with the intent and purpose of the law.

In the event no objection to the proposed encroachment is filed with the Board and no hearing(s) is requested by private property owners, state or federal agencies, or ordered by the Board, based upon its investigation and considering the economics of navigational necessity, justification, or benefit, public or private, of the proposed encroachment as well as its detrimental effects, if any, upon adjacent real property and lake value factors, the Board shall prepare and forward to the applicant by certified mail its decision. The applicant, if dissatisfied with the decision, has 20 days from the date of the mailing to notify the Board to request a reconsideration.

Should the Board grant a permit, a condition of the permit may require a lease or easement for use of any part of the state-owned bed of the lake. Recordation of an issued permit in the records of the county in which an encroachment is located is a condition of issuance of the permit and proof of recordation must be furnished to the department by the permittee before a permit becomes valid.

Approximate Time Required for Processing

Processing of an application may take several months, especially if objections to granting the permit are filed by private land owners or state or federal agencies.

Permit or Regulation: 404 Permit

Statutory Authority: 33 United States Code 401-1241; 33 CFR 320 and 322 through 329

Agency: U.S. Army Corps of Engineers (COE); Idaho Department of

Water Resources (IDWR)

Construction of structures within, dredging, and filling of navigable waters or wet lands as classified by the Corps of Engineers (COE) requires a 404 Permit. These are permitted by the COE, depending on the complexity of the activity. General, Regional, and Nationwide Permits allow more common, generic types of activities without formal evaluation. The individual permit must be obtained for larger, more unusual actions that could result in major impacts to the water way. 
The basis for evaluating the permit application include effects of the activity on:

- the public interest and use of the water way resource

- the resources of wet lands

- fish and wildlife

- water quality

- ... historic, cultural, scenic, and recreational values

- adjacent properties or water resource projects

- other federal, state, or local requirements

- flood plain management

- water supply and conservation

- energy conservation and development

- navigation

The availability of alternative methods that would result in less harmful effects is also an important consideration.

A standard form must be completed and submitted together with maps, plans, and specifications for the activity relating to its effect on the water way and/or wet lands. If a Stream Channel Alteration Permit and/or State Land Easement or Special Permit is required for the activity, a joint application for the permit can be filed with the Idaho Department of Water Resources (IDWR) and copies will be sent to the other agencies. The IDWR will coordinate the process of the permit application.

Upon receipt of the completed application, the regional COE office will publish a public notice of the applications and request input from regulating agencies, individuals, and interest groups with a 15 to 30 day period. Substantial objections will result in a public hearing being held. Objections from public agencies must be resolved before the permit can be issued.

Approximate Time Required for Processing

Most permits will be issued within 60 days of application, although more controversial projects may take 120 days or longer.

\section{Permit or Regulation: Motor Vehicles}

Statutory Authority: Idaho Code, Title 49

Agency: Idaho Transportation Department (ITD)

Commercial Vehicle Licenses - Special vehicle licenses are required for any commercial vehicle.

Temporary Trip Permit - This is required for all commercial vehicles licensed in other states and operating in Idaho. Permits can be purchased at ports of entry and other truck checks within the state for $\$ 12$ plus a fee based on combined gross weight and mileage. 
Oversize Permit - Without an oversize permit, maximum width for a commercial vehicle is 8' 6 " wide, 14' high, $48^{\prime}$ ' long on a single trailer or $60^{\prime}$ long on a double trailer, unless the overall length including the coupling is $75^{\prime}$ or less. Some roads cannot be traveled by an oversize vehicle. This is an annual permit.

Overweight Permit - Normal permitted weight for a commercial vehicle is 80,000 lbs. An extra weight permit may be obtained, but does not allow the holder to exceed the legal access weight (weight per axle). Some roads cannot be traveled by an overweight vehicle.

\section{Fish/Wildlife}

\section{Permit or Regulation: Fish and Wildlife Impact Evaluation Statutory Authority: Idaho Code, Sections 36-103 et seq. Agency: Idaho Department of Fish and Game (IDFG)}

In Idaho, all wildlife, including wild animals, wild birds, and fish are declared to be the property of the state. The Idaho Fish and Game Commission, acting through the Idaho Department of Fish and Game (IDFG) implements and enforces regulations regarding fishing and hunting, and also carries out actions to protect and enhance fish and wildlife populations and their habitats.

While regulations and IDFG authority is quite specific with regard to harvest, transport, capture, and management of fish and wildlife populations, IDFG's authority to manage habitat is not as clearly defined.

Since fish and wildlife habitats are generally controlled by state or federal land and water management agencies, the IDFG frequently exercises its influence through the regulatory processes of these agencies. By influencing how habitats are managed, the IDFG can effectively manage fish and wildlife populations and the effects that can be caused by any facilities that may be constructed in these areas. To illustrate, the IDFG could act as an intervener in proceedings before other agencies to acquire air, water, waste, or other permits.

There are no permits issued by IDFG to certify that fish and wildlife impacts have been adequately mitigated or do not exist. Nevertheless, because the agency can and will influence various aspects of the project through their actions, developers are strongly encouraged to consult with the agency very early in the planning process. The IDFG will closely coordinate with other agencies as appropriate. 


\section{Forest Areas}

Permit or Regulation: Slash Disposal Permit

Statutory Authority: Idaho Code Title 38, Chapters 1 and 4

Agency: Idaho Department of Lands (IDL), Board of Land Commissioners

Any burning operation conducted for the purpose of hazard reduction shall be in accordance with the law requiring burning permits during the closed fire season. Persons conducting burning operations must have sufficient men, tools, and equipment on hand to immediately stop the uncontrolled spread of fire. Burning operations shall be planned, prepared, and executed in such a manner that forest resources are not damaged and air quality standards are met.

\section{Permit or Regulation: Timber Removal}

Statutory Authority: Idaho Code Title 38, Chapters 1 and 4; IDAPA 20.19

Agency: Idaho Department of Lands (IDL), State Board of Land Commissioners

A permit is required from the Idaho Department of Lands (IDL) for timber cutting on state granted easements or right-of-ways.

\section{Safety/Health}

\section{Permit or Regulation: Solid Waste}

Statutory Authority: Idaho Code, Section 39-105

Agency: Idaho Department of Health and Welfare (IDHW)

Any land area used for the storage, transfer, processing, separation, incineration, or disposal of solid waste having no intended future use must be approved by the Idaho Department of Health and Welfare (IDHW).

The issues involved in obtaining a permit deal with existing environmental and land use conditions in the area (depth to groundwater, soils conditions, prevailing winds, type of and distance to nearby land uses, etc.), proposed design and operation procedures, and restoration plans.

A complete application must be submitted on a standard form and provide plans, maps, specifications, and proposed operational procedures. Applications should be submitted to the IDHW or to the local health district at least $\mathbf{3 0}$ days prior to the date of expected action. The application must be accompanied by a statement from the local land use authority(s) regarding compatibility with existing planning and zoning ordinances.

The application must be approved by the land owner, county commissioners, and local health district office before the IDHW will approve. 
Permit or Regulation: Hazardous Waste

Statutory Authority: Idaho Code, Sections 39-4401 and 39-5800 et seq.; Federal Resource Conservation and Recovery Act 42 USC 6901

Agency: Idaho Department of Health and Welfare (IDHW); Environmental Protection Agency (EPA); Hazardous Waste Board

Owners or operators of facilities that provide treatment, storage, or disposal of more than 220 pounds of hazardous waste per month must have a Hazardous Waste Permit from the Idaho Department of Health and Welfare (IDHW). Generation of less than 220 pounds per month is exempt from most hazardous waste standards and permitting requirements if the disposal of the waste is on-site or at a state approved disposal site for hazardous waste, or if the waste is treated on-site.

The permit application will be evaluated on the type of waste to be handled, security procedures proposed, plans for periodic inspection of the facilities, plans for preventive action and emergencies, design and layout of facilities, geologic and hydrologic information, safety training program for personnel, and plans for closure of the facility. Impacts on groundwater and soils will be closely evaluated.

Applications must be submitted to the IDHW and the Environmental Protection Agency (EPA). Once a completed application is accepted by IDHW, the Department must act on the application within 120 days or refer it to the Hazardous Waste Board for review and action within 120 days.

Approximate Time Required for Processing.

The application process can be expected to take up to 1 year. EPA process of an application of the federal permit should require a similar amount of time.

Permit or Regulation: Boiler Safety

Statutory Authority: Idaho Code, Section 67-5204 as amended

Agency: Idaho Department of Labor and Industrial Services (ILIS)

All boiler and pressure vessels manufactured or installed in the state of Idaho or shipped into Idaho must be constructed in accordance with the requirements of American Society of Mechanical Engineers (ASME) Boiler Code (1983) and bear the stamp of the Natural Board of Boiler and Pressure Vessel Inspectors.

All boilers and pressure vessels must be installed and maintained in conformity with the requirements of the ASME Boiler Code (1983), and Chapter I through IX of the National Board of Boiler and Pressure Vessel Inspectors Inspection Code (1983) and Idaho Code 67-5204.

All welding and installation of boilers and power piping shall be in strict accord with the ASME Boiler and Pressure Code (1983), and the ASME Power Piping Code (ANSI B 31.1-1983). Each manufacturer and contractor shall be responsible for the welding done by his organization and shall have each welder tested in accordance with ASME requirements prior to performing and welding covered under Idaho Code 67-5204. 
All boiler and pressure vessels installed or operated in the state of Idaho shall have an inspection conducted by a person holding a certificate of competency which must result in the issuance of a certification of inspection before such vessel is placed in operation. Whenever an inspection is made by a person holding a certificate of competency, a copy of the inspection report shall be submitted on forms as outlined in the National Board Inspection Code. Boiler inspections are done by certified inspectors in the employment of insurance companies who insure the boilers.

Boilers that do not specifically contain all the fail-safe features necessary to operate fully unattended shall have qualified boiler attendants.

\section{Permit or Regulation: National Pollution Discharge Elimination System (NPDES) Statutory Authority: 33 United States Code 1251; 40 CFR 125 Agency: Idaho Department of Health and Welfare (IDHW); U.S. Environmental Protection Agency (EPA)}

The owner/operator of any proposed activity (i.e., mining) that will discharge wastewater into surface waters by way of a discrete conveyance (pipe, ditch, etc.) must first obtain a National Pollution Discharge Elimination System (NPDES) Permit. For each facility in the operation discharging separately, a separate application is required.

The NPDES permit process addresses the amount of pollutants to be discharged to surface waters. Important considerations include: the content of the process effluent; proposed treatment prior to discharge; and the particular body of water into which the discharge will be made.

For most operations, "best management practices" (schedules of activities, prohibitions or practices, maintenance procedures, and other management practices to prevent or reduce the pollution of surface waters) must be implemented. Monitoring and reporting of discharge is required as is annual reporting of compliance with the regulations.

Applicants are to register with EPA and the Idaho Department of Health and Welfare at least 180 days prior to construction of the proposed operation. Information to be submitted includes:

- information about the owner, operator, and facility

- proposed treatment for processing wastes

- description of proposed runoff storage facility, including area drained, capacity, and design safety considerations

- measures to divert flowing surface water

- a sketch of the operation showing relation to surface water

- an operational plan to ensure compliance with the permit requirements

The basis for evaluation of an NPDES application by EPA staff is 1) adherence to EPA-specific effluent guidelines; 2) state water quality standards for the specific body of surface water; and 3) water quality certification performed by the state (see below). 
After the requirements and conditions for granting the permit have been developed, a 30-day public notice is given during which any objections to the granting of the permit must be made. Substantial objections could result in a public hearing.

Approximate time to process the permit application is 3 to 6 months.

\section{Local Government Permits}

Within the framework of federal and state regulation, local governments perform duties which can have unique and significant impacts on energy project development. Local governments can set an example by financing and developing energy facilities themselves. They can encourage private development through information distribution and active recruiting of facilities. Cities and counties also regulate energy facilities. Below state-level citing thresholds, the jurisdictions are the primary development permitting authority. They set land use policy which controls the type and location of future development and affect constriction techniques by enforcing building and electrical codes. They direct the division of lots through subdivision ordinances. They also regulate the type, mix, and location of land uses using zoning ordinances.

Zoning ordinances implement policies established in local land use plans and reduce land use conflicts by dictating: 1) the type of development allowed within the jurisdiction; 2) the design of those uses; and 3) the way potentially conflicting uses may coexist.

Policies and standards reflect both technical information and popular opinion. Local land use law often reflects values that are difficult to evaluate objectively. Public participation in a project approval may reveal concerns for property values, neighborhood quality, and scenic quality. These subjective values are difficult to put into laws. Few local governments have done more with energy facility regulation than provide a forum for public involvement in siting decisions.

In some states, counties and incorporated cities prepare and adopt comprehensive land use plans which are acknowledged by a state-level commission. The plans indicate the location and significance of affected resources and provide a regulatory framework for potentially using them. If a conflict is identified which is resolved against energy resource development, then another site must be found, unless the plan is amended. If the conflict is resolved in favor of energy resource development then, from a land use perspective, resource use is feasible. Development still may be subject to conditions which mitigate negative impacts. These requirements are described in the plan and local ordinances. Thus, developers can use comprehensive plans to learn what kind of projects might be feasible, and under what conditions.

Some counties discuss renewable resources in their comprehensive plans. However, discussion in the plans has often not led to zoning and ordinances. Frequently, adequate and up-to-date data on resources' location, quantity, and quality has not been given to local governments. Also, energy issues are not a priority in land use planning circles or most local governments. 
In the absence of attention to the energy resource in the local land use plan, a prospective developer may have to champion a project proposal through the entire land use planning, zoning, and ordinance-writing processes. Such an effort would add many months to a project's lead time and increase its cost. Along the way, design changes are likely or the project may be found infeasible. The local government and public would be involved in broad planning, policy-making, and ordinance issues in the context of community reaction to a proposed project.

Local governments such as cities, counties, road districts, flood control districts, and drainage districts will have some jurisdiction over geothermal development in nearly all cases. Most county governments in Idaho require building permits for construction and entail building code, electrical code, and plumbing code compliance. Most counties also have planning and zoning commissions that will review project plans for compliance with comprehensive plans, zoning regulations, and needs for conditional or special use permits. Counties may also have some jurisdiction over construction in or near defined flood plains and over use of, or construction near, county highways. The county courthouse, the county zoning administrator, and the county highway district are the best contacts for determining what permits or approvals will be required.

If a proposed site is within a city's limits or within its area-of-impact, appropriate contact should be made with city officials regarding building permits, zoning regulations, flood plain construction, and highway usage. Contact the city hall of the nearest city for a determination of the required permits and approvals and jurisdiction.

Smaller communities often issue all permits through a single office, such as the Clerk's Office. In some counties, one or more highway districts exist that are responsible for construction and maintenance of roads. These agencies will be the administrators of all permits/approvals having to do with public rights-of-way.

A number of these permits, mainly those administered by the local planning departments, will involve substantial discretionary action on the part of the decision makers, approval being based on conformance of plans with established criteria or standards. Therefore, these decisions will usually be made by elected or appointed officials (city councilmen, county commissioners, or planning and zoning commissioners). Another group of approvals will be based on the adequacy of technical plans. These will generally be the permits listed as being administered by the public works department and building department. Several items will be simply a matter of registration, including the business license and registration of proprietorship. The following is a general description of each of the permits and approvals which may be required.

\section{Determining Which Permits are Required}

To enable a developer to determine what local permits are necessary for a particular site, and for guidance in obtaining local permits, the following guidelines are provided. 
- Determine with certainty within what local jurisdiction the project site lies. Assumptions about jurisdiction are often inaccurate. Even if a site is within the county, it is possible it may be within a city's Area of Impact, which would give the city certain jurisdiction over the project.

- Contact agency staff early to obtain information about permits and to discuss your plans. Go into their office in person to make personal contact and to show your commitment to expediting the permitting process.

- Determine what permits will be required for the proposed project; what information should be provided; the process that will be followed; and time frames, including submittal dates, hearing dates, and the time within which a decision can be expected.

- Get copies of the applicable regulations so you can personally review them and the evaluation criteria. Ask questions if the written regulations vary from information the staff has provided.

- In the case of more discretionary permits, ask the staff about the likelihood of approval; also what might help to speed up the process and decision.

- Submit a complete application. Incomplete applications will result in processing delays.

- Attend all meetings where the application will be discussed. If there is no one to respond to questions, delays may occur or the permit may be denied.

\section{Land Use}

\section{Permit or Regulation: Comprehensive Plan Amendment Agency: Planning and Zoning Commission.}

Most cities and counties in the state have a comprehensive plan establishing goals and policies for development. A project that will conflict with the goals and policies requires a change in the plan that will eliminate the conflict. Such an ameridment is a major change in policy and thus requires public hearings and considerable time (minimum about 3 months). The process normally requires a written proposal on how the plan should be amended, a public hearing by the Planning and Zoning Commission with a recommendation to the elected body, and a hearing by the elected body prior to a decision. Planning and Zoning Commissions are authorized by law to make such recommendations to the elected body only twice a year. 


\section{Permit or Regulation: Zoning Certificate \\ Agency: Local Planning and Zoning Department}

A zoning certificate is issued to ensure that a project to be constructed is allowed in the particular zone. It will be required to obtain a building permit. If the zoning is proper for the proposed use, the certificate can often be issued immediately by the staff. Information required usually pertains to the proposed location and use.

\section{Permit or Regulation: Rezoning Agency: Planning and Zoning Commission}

Most cities and counties in the state have established zoning within their boundaries. Each zone has land uses permitted either outright or by special permit. If the proposed energy project is not among uses permitted in the designated zone, the zoning must be changed to permit it at that site. A standard form is usually completed for the application. The hearing and approval process is essentially the same as for a Comprehensive Plan Amendment.

\section{Permit or Regulation: Special/Conditional Use Agency: Planning and Zoning Commission}

Land uses that are only permitted within the zone by special or conditional use permit must be considered in a public hearing by the Planning and Zoning Commission or the elected body. Their consideration is to address whether the proposed use is appropriate in the particular location, taking into account surrounding land uses, condition of streets, and other site factors. Conditions on the design and operation of the proposed use can be established in the permit. Application usually requires submittal of a standard form and plans for the proposed project.

Approximate Time Required for Processing

Minimum time to secure a permit is normally about a month to month and a half.

\section{Permit or Regulation: Variance}

\section{Agency: Local Board of Appeals/Planning and Zoning Commission}

Within each zone, standards are established regarding the location of structures on the property. If, for some reason involving unusual property conditions, compliance with the standards is impractical, a variance may be granted. Application usually requires a map showing the subject property, its unusual conditions, and surrounding property. A local Board of Appeals may hold the public hearing to consider the application and approve or deny the request. If a local Board of Appeals does not exist, the procedure is usually similar to that for a rezoning, with the Planning and Zoning Commission recommending to the elected body, who must approve or deny the variance. 
Approximate Time Required for Processing

Minimum time for processing is about a month, though it will depend on the process of the particular jurisdiction.

\section{Permit or Regulation: Floodplain Development Agency: Planning and Zoning Commission}

Where a project is proposed to be built near a body of water, a floodplain permit is often required. The major issue is usually the effect of the project on flooding conditions and on other properties. Application is made through submittal of topographic maps showing the location of the proposed development. Generally a public hearing will be held by the Planning and Zoning Commission, who will decide whether to issue the permit.

Approximate Time Required for Processing

Normal processing time is about 30 days but may vary greatly.

\section{Construction}

\section{Permit or Regulation: Design Review Approval Agency: Local Planning and Zoning Department}

This process examines the functional logic and aesthetic impacts of proposed development plans, and is much more often a requirement of larger city governments than a county. A design review committee consisting of design professionals and lay public often conducts such reviews.

\section{Approximate Time Required for Processing}

Processing time may be as little as 2 weeks.

\section{Permit or Regulation: Sign}

\section{Agency: Local Planning and Zoning Department}

A permit is often required for a sign to certify that it complies with adopted standards. Other :permits required for larger or special types of signs are usually similar to Conditional Use Permits. Application for a sign permit is likely to require submittal of plans, including a scale drawing of the sign and a plan showing how and where it is to be located.

\section{Approximate Time Required for Processing}

Processing usually consists of staff review of the plans for conformance with ordinance requirements and may take as little as several days. 
Permit or Regulation: Approval of a Private Road Agency: Local Planning and Zoning Department/Planning and Zoning Commission

Zoning ordinances often require public approval of a private road to ensure that adequate access will be provided to all parcels served by it and to evaluate its impact on the public street network. A plan of the proposed road showing dimensions, improvements, adjacent parcels, and land ownership generally serves as application. Approval may occur at the staff level after review, or may be granted after review by the Planning and Zoning Commission.

\section{Approximate Time Required for Processing}

Processing time will usually be a few days if approval can be made at the staff level, and may be several weeks if review by the Planning and Zoning Commission is required.

\section{Permit or Regulation: County Road Access}

Agency: Local Public Works Department; Local Highway District

Many counties require approval for a proposed driveway or private road that will access from a county road. To obtain approval, a drawing of the proposed driveway/road showing location of access and relation to intersections, hill, etc., will probably be required.

Approximate Time Required for Processing

Approval is generally by the staff and can be granted within 2 weeks of application submittal.

\section{Permit or Regulation: Approval of Public Road Plans}

Agency: Local Public Works Department

Any street to be dedicated to the public for maintenance purposes must meet established standards for public streets and be approved by the responsible authority for streets and roads. If accomplished as part of a subdivision, processing will be as specified for subdivisions. If being undertaken as improvement to an existing street, plans are submitted to the street authority for review and approval.

Approximate Time Required for Processing

Processing can often be accomplished within several weeks.

\section{Permit or Regulation: Right-of-Way Encroachment Agency: Local Public Works Department}

Any work to be carried out within a public right-of-way requires a permit to interfere with the right-of-way. An application must state why such encroachment is necessary and the duration. In some cases, formal permits are not issued, but notification of the road authority with jurisdiction is necessary. 
Approximate Time Required for Processing

Approval is by the staff and should be granted within several weeks.

\section{Permit or Regulation: Utility}

Agency: Local Public Works Department

Installation of utility lines in a public right-of-way requires a utility permit. Plans must be submitted for staff review and approval.

Approximate Time Required for Processing

Processing may be accomplished within several weeks.

\section{Permit or Regulation: Building Permit/Occupancy}

\section{Agency: Local Building Department}

The issuance of a building permit is based on the compliance of proposed plans with the adopted building code. In some counties, the building permit may be administered by the State Department of Labor and Industrial Services. The occupancy permit allows utilities to provide permanent service to the use. It is issued after on-site inspection confirms that construction has been carried out in conformance with plans. Notice of construction completion must be given to trigger the inspection.

\section{Approximate Time Required for Processing}

Timing for issuance of an occupancy permit will vary greatly depending on staff schedules, but can reasonably be expected to occur within 1 or 2 weeks of notification.

Timing for issuance of a building permit for an industrial use can be expected to be at least several weeks after submittal of building plans.

\section{Safety/Health}

\section{Permit or Regulation: Discharge to the Public Sewer System} Agency: Local Public Works Department

In order to discharge project effluent into a public sewer system, a permit is required by most municipalities/sewer districts. Information about the character and amount of effluent and times of discharge must be supplied in the application. While evaluation and approval will normally occur at the staff level, the matter may be presented to the elected body prior to issuance of a permit for its concurrence.

Approximate Time Required for Processing

Timing on the permit may be several weeks to a month. 


\section{Other Permits}

Permit or Regulation: Registration of Sole/General Proprietorship Agency: County Recorder

The County Recorder is responsible for registering all sole general proprietorship business. 


\section{Permit Summary Sheet}

MONTANA

Thermal Thermal Trans-

Permitting Resources Resources mission Hydro Hydro Cogen- wind Biomass Geo-

Agency $<50>50$ Lines $<50 \quad>50$ eration Wind Biomass thermal

MAJOR FACILITY SITING/ENVIRONMENTAL

\section{IMPACT}

Montana Major Facility Siting Act Certificate

Montana Environmental Policy Act

AIR QUALTT

Air Quality Permit

Prevention of Significant Deterioration

\section{MDNRC}

Varies

MDHES $\uparrow \quad \uparrow$

WATER QUALITY/WATER USE

Beneficial Water Use Permit

MDHES

Geothermal Leases on State Land

FWP,LA,COE

Hydroelectric Power Development on

MDSL

State Lands (easement)

Hydroelectric Power Development at

State-Owned Dams (easements)

MDSL

LAND USE

Floodplains and Floodway Permits

Heritage Sites Permits

Natural Areas (Land use limitations)

Geothermal Leases on State Lands and

Easement on State School Trust Lands

State-Owned Lands (permits, leases,

casements)

Soil and Water Conservation District

Land Use Regulations

Local Zoning and Land Use Regulations

\section{CONSTRUCTION}

Highway Encroachments (Easements)

Highway Utility (Easements)

Public Water Supply (License)

Sewer System Approval

Building Permits

Mechanical, Electrical, and Plumbing

Permits

Overhead Lines

Lakeshore Work Protection (Permits)

FOREST AREAS

Slash Disposal/Timber Cutting Permit

SAFETY/HEALTH

Montana Water Pollution Discharge Permit

Solid Waste Disposal (License)

Hazardous Waste Disposal (Permit)

Boiler License

Dam Safety Construction/Operation Permits

OTHER

FERC Certification

FISH/WILDLIFE

Fish and Wildlife Impact Evaluation Need

MDSL
MDSL
MDNRC,LA
MSHPO
MDSL,MDFWP

MDSL

$+\quad t \quad t$

MDSL

LA

LA

$+$

$\mathbf{x}$

$*$
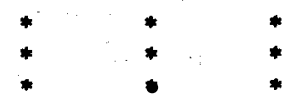

MDT

MDHES

LA

LA,MDC

i

A,MDC
LA

MDSL

MDHES
MDHES
MDHES
MDLI
MDNRC

+
-
+

\section{Agencles Key}

MDNRC Montana Dept. of Natural Resources and Conservation

Varies Lead agency varies by project

MDHES Montana Dept. of Health and Environmental Sciences

LA Local agencies

MDSL Montana Department of State Lands

MSEIPO Montana State Historic Preservation Office

MDT Montana Department of Transportation

MDC Montana Department of Commerce

MDFWP Montana Department of Fish, Wildlife, and Parks

MDLI Montana Department of Labor and Industry

BHES Board of Health \& Environmental Sciences

FERC Federal Energy Regulatory Commission

COE Corps of Engineers

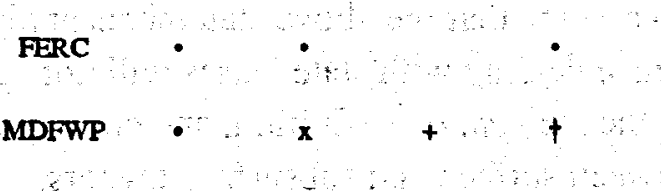

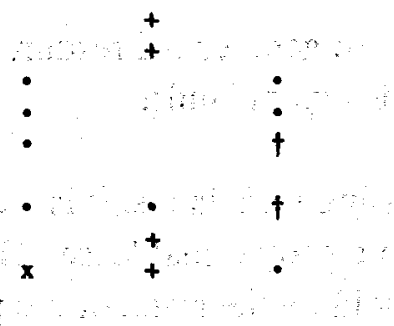

$\begin{array}{llllll} & & * & * & & \\ \mathbf{x} & * & * & * & * & * \\ \mathbf{x} & * & * & * & *\end{array}$




\section{Chapter 3 \\ The Montana State Process}

\section{Legal Definition and Determination of Ownership}

The Montana state lands leasing statute defines geothermal as follows:

'Geothermal resources' means the natural heat energy of the earth, including the energy, in whatever form, which may be found in any position and at any depth below the surface of the earth, either present in, resulting from, created by, or which may be extracted from such natural heat and all minerals in solution or other products obtained from the material medium of any geothermal resource (77-4-102[1], Montana Code Annotated).

Montana has characterized geothermal as sui generis (unique unto itself) (77-4-104, MCA). However, Montana statutes involving ownership of geothermal are somewhat ambiguous and lead to the conclusion that geothermal resources are considered to be water. The relevant section on the management of state-owned lands (77-4-105, MCA) states:

No right to seek, obtain, or use geothermal resources has passed or shall pass with any existing or future lease of state or school lands.

Thus, at least with respect to leasing state lands, it is clear that geothermal rights are reserved, unless included explicitly within a geothermal lease. However, the question remains open with respect to lands that have been sold by the state, or are proposed for sale. Are geothermal rights included in the mineral reservation, or do they pass with ownership of the surface? Section 77-4 $105, \mathrm{MCA}$, quoted above, lends weight to the contention that geothermal resources are included in general mineral rights. However, the declaration in 71-4-104, MCA, that geothermal resources are neither a mineral nor a water resource would lead to the opposite conclusion.

While it may seem reasonable to assume that the above statements apply, in general, to private lands in Montana, the final sentence dealing with state leases will not apply. Thus, with respect to private lands, we are left with the sui generis definition, and consequently, have little guidance for the resolution of disputes between surface and subsurface owners.

Montana has attempted to minimize conflicts through its claim that despite how the resource has been characterized, geothermal resources must be regulated as water. Montana Water Use Act 85-2-101 et seq., MCA, requires a permit for appropriation for any use of water over $0.38 \mathrm{~m}^{3}$ (100 gallons) per minute. A permit must be issued if the applicant proves by substantial credible evidence that:

1. unappropriated water in the supply source at the point of diversion is available, in the amount and during the period required by the applicant 
2. the rights of prior appropriators will not be adversely affected

3. the proposed means of diversion, construction, and operation of the appropriation works are adequate

4. the proposed use of the water is a "beneficial use"*

5. the proposed use will not interfere unreasonably with other planned uses or developments for which a permit has been issued or for which water has been reserved

6. the applicant has a possessory interest or written consent to use the property where the water is put to beneficial use

Montana's water laws apply to all geothermal development, regardless of ownership, involving production and diversion of geothermal fluids. "Geothermal Water" is, in fact, included in the Montana Water Use Act definition of water, although geothermal is not defined. Thus, any developer of geothermal resources would be advised to secure the necessary water rights.

\section{Obtaining Access to Geothermal Resources}

\section{State Lands}

The Montana Board of Land Commissioners may lease state-owned lands, including the lands of navigable streams and the lands of navigable bodies of water, for the purposes of prospecting, exploration, well construction, or production of geothermal resources (77-4-101 et seq, MCA.).

Montana leases all lands through a competitive bidding process (Sacarto, 1976). In Montana; however, if only one person or company bids for the tract offered, an applicant may negotiate a lease with the Montana Department of State Lands. The Montana Department of State Lands may, however, choose to reject all bids and applications (Perlmutter and Birkby, 1980). Developers may be required to pay annual rentals, pay production royalties, and diligently explore for and develop the resource.

\section{Indian Lands}

In the $1850 \mathrm{~s}$, a series of treaties were negotiated between the United States and a number of the Indian tribes.

* The Montana Department of Natural Resources and Conservation (MDNRC) considers heat extraction a beneficial use. Additional and more stringent criteria must be proved for appropriations of 4,000 acre feet or more per year and 5.5 or more cfs. 
In exchange for giving the United States title to most of their land, the Indians retained reservations for homelands as well as a right to continue hunting and fishing at their usual and accustomed places, both on and off the reservation.

All of the treaties were negotiated, executed, and ratified by Congress well before statehood. In the ensuing decades, the treaties were interpreted by the federal courts. The court rulings followed earlier Supreme Court rules concerning Indian treaties and established several basic principals. Most fundamentally, the rights retained by the tribes are reserved rights, that is they are rights retained by the tribes at the time of treaty-making, and not given to them by the United States.

Each tribe that signed a treaty has a property right to the use of the resources in question. As a property right retained from before statehood, treaty rights are in the nature of easements on other real property interests.

Treaty rights have also been found by the federal courts to include an environmental right. For example, court decisions have forbidden actions that would inundate usual and accustomed fishing sites, dewater fish habitat, or degrade water quality to the detriment of the fishery.

Indian water rights stem from a 1908 Supreme Court decision which stated that when land was set aside for reservations, it was implied that water was also reserved for tribal uses. It does not matter if the water has been put to use or not, it is still reserved for use on the Indian reservation.

Though altered somewhat by subsequent court cases, the Winters Doctrine, as this decision is known, remains the basis for Indian water rights. The Winters Doctrine usually refers to direct water use, rather than the protection of instream flows for fish habitat. There are many Winters Doctrine-based water claim cases currently in state and federal courts. The outcome of these cases could have a profound impact on current western United States water use.

In 1984 the EPA announced that it would "work directly with Indian tribal governments on a one-to-one basis." This policy recognizes tribal governments as sovereign entities with primary responsibility for reservation environmental issues, such as air and water quality and related matters. This means that the tribes can contract directly with the EPA to administer the Clean Water Act, the Clean Air Act, and similar environmental programs on their reservations (Brown, 1991).

Individual Indian lands (allotments) held in trust by the U.S. or tribal land held in trust by the U.S. can be permitted or leased for mineral development under authority of a March 3, 1909, act, Leases of Allotted Lands for Mining Purposes, or a May 11, 1938, act, Leases of Unalloted Lands for Mining Purposes, Duration of Leases, and the 1982 Indian Mineral Development Act. These acts are regulated by 25 CFR 211.212, and 216, and by 43 CFR 3100 through 3590 . The Bureau of Indian Affairs (BIA) is responsible for exploration permit, lease approval, and administration. The BIA is responsible for operational supervision of prospecting and development. 
Access to Indian lands for non-disturbing surface exploration requires written agreement between operators and Indian land owners. Surface disturbing activities, including prospecting and development, require approval by BIA and BLM. The point of first contact should be between the prospective operator and tribal governments.

Finally, and perhaps most significantly, the tribes as governmental entities have a right to manage their resources. This means that the tribes undertake all activities necessary to adequately manage the resource, including protecting the environment necessary to sustain the resource (see The Federal Process, for additional information on Indian lands).

\section{Tribal Requirements}

Development on tribal reservation land may be subject to tribal laws not detailed in this guide. The appropriate tribal planning office should be contacted prior to conducting activities on tribal land. For a list of tribal contacts, see Appendix 1F.

When a project is on non-tribal lands but may affect treaty-reserved resources or areas of tribal significance, agencies have an obligation and responsibility to consult with tribal governments during the project review process. Mitigation may be required to protect treaty rights.

Prevention of damage to Indian graves or artifacts is required. Unlawful removal or mutilation of artifacts or burial sites is punishable as a felony under state law.

\section{Private Lands}

Developable resources are often found on private lands. Accordingly, one of the first activities is to gain access. Access to private land can be obtained by sale, lease, permit, option, or any other mutual agreement with the owner of the surface property and geothermal estate.

Landowners may permit access prior to a lease or purchase option. This allows the developer to conduct agreed upon preliminary exploration activities. Such activities could include geological and geophysical investigations that are non-surface disturbing and the drilling of temperature gradient holes. (A state well drilling permit is required for exploratory drilling on private land.) Additional federal, state, and/or local permits are required for continued development. These are covered in subsequent sections.

\section{Sales}

A landowner who sells property to a developer transfers all interest and control in the property and its geothermal resources for a fixed price. The landowner does not incur the risks of development. The developer pays the market value of the property, taking into consideration any value added by the resource. A landowner who is paid in full need not be concerned with the development. However, a landowner who is to be paid over time from the project's geothermal re- 
source or electricity sales revenues may retain some control over the property and its development as security for future payment. A landowner who wants to use the property for farming or grazing can lease back the property sold to the developer.

\section{Lease}

Instead of selling the property, the landowner may rent or lease it to the developer for a fixed term. In most instances, access to private land is obtained through a geothermal lease. Leasing terms generally include length of lease, royalty payments, lease fees, and stipulations governing exploration and development activities. Terms are often based on state and federal oil, gas, and geothermal leasing guidelines. A lease or rental agreement allows the landowner to retain some control over the development and use of the land.

\section{Option to Purchase or Lease}

Instead of an immediate purchase or lease, the developer can buy an option by paying the landowner a sum, usually a small percentage of the property value. The option holds the property off the market while the developer determines whether to make a final purchase or lease. The terms of the final purchase or lease are negotiated and set forth in the option agreement.

Two agreements are needed for the developer to obtain the right to purchase or lease the property later and the right to install testing devices or complete an exploration process: an option's agreement, and a short-term lease or license agreement. Either a license or lease allows the developer to use the land during the option period.

At the end of the option period, the developer must decide whether to purchase or lease the property at the price and terms in the option agreement, or to give up all interest in the land. An option assures that the developer can buy or lease the property for a set price in the future. For instance, the developer can buy an option to purchase or lease the property at a low price in 5 years. If exploration shows that the property has valuable resources, the developer can exercise the option at the low price despite the increased value of the land. However, if tests show that the resource is less valuable than thought, the developer is not bound to buy or lease the property.

The landowner cannot accept a better offer during the option period. The option price should adequately compensate the landowner for keeping the property off the market. The value of an option right depends on the length of the option period and the strength of the resource. If more than one developer wants to buy an option, the competition will increase the value of an option.

\section{Right of First Refusal}

A right of first refusal is often confused with an option to purchase. Unlike an option, a right of first refusal does not set a price for the property. A developer who buys a right of first refusal merely obtains a right to match any offer to buy the property. Thus, a landowner who receives 
an acceptable offer from a third party would be required to communicate the offer to the developer. The developer then has the right to match the offer and obtain the property or allow the property to be purchased by the offeror.

A landowner may specify that a right of first refusal does not apply to offers to purchase made by specific parties such as family members. This allows the landowner to transfer ownership within a family while granting a developer a right of first refusal on offers made by others.

If the area of interest is already under lease for other purposes such as farming or grazing, the developer must secure permission through easement from the lessee for surface access rights.

\section{Easement}

A developer can negotiate an easement for access with adjoining landowners. An easement is a right to make limited use of real property in airspace. A landowner can sell an easement granting the developer the right to use the space across and above the property. This grants a positive right. An adjoining landowner may also agree to restrict vegetation, structures, or other objects that would impair or obstruct transmission lines. This is called negative easement.

An easement may be perpetual or for a specified time. Once granted, a perpetual easement may not be terminated except as stated in the easement, by court decree based upon abandonment or changed conditions, or by agreement of the parties.

To be effective, an easement must be in writing and be recorded in county property records. A landowner who has granted an easement can sell the property but the new owner will be bound by the terms of the easement. Similarly, if the developer sells the property benefited by the easement, the new owner will be entitled to the same rights as the developer. This is what the law means when it says that the easement is appurtenant to the land and follows with the real property benefited and burdened by the easement.

Easements may also be granted for uses other than access to energy resources. The uses of the easement are stated in the easement: For instance, an owner of adjoining property may grant a developer an easement to cross the property to install and repair equipment or the right to erect and maintain transmission lines. Easements from several parties may be necessary to install transmission lines.

\section{Covenant}

When property is sold, restrictions may be placed in a purchaser's deed prohibiting certain uses of the land. A developer who acquires only part of a larger parcel can ask the landowner to agree that when other parcels are sold, the deeds will contain restrictive covenants prohibiting new owners from obstructing the developer's access. Restrictive covenants that preserve access must be in writing and should be recorded. Recorded covenants bind successive purchasers of land burdened or benefited by covenants. 


\section{Permit or License}

The landowner may grant the developer a permit or license to use the land or airspace for a specified time or purpose. This right is generally revocable at the landowner's will and may not be transferred or assigned. The developer who acquires a personal license or permit does not acquire a legal interest in land that can be recorded or mortgaged.

\section{Contract Provisions}

Both the developer seeking access rights and the landowner interested in leasing resources would be wise to invest in competent legal advice. Consultation with a qualified accountant regarding royalty payments and applicable tax laws is also advised. Contracts for a purpose, such as oil and gas leasing, may not be appropriate for geothermal development. The parties should design a contract that meets their specific needs and time requirements of the project.

\section{Montana State Agency Responsibilities}

\section{Agency: Environmental Sciences (MDHES)}

Statutory Authority: 2-15-2101 MCA

The Environmental Services (MDHES) is responsible for administering the Montana Clean Air Act and implementing clean air programs and plans mandated by the Federal Clean Air Act. Any proposed project that has the potential to emit more than 25 tons per year of any pollutant must obtain an air quality permit before beginning construction. MDHES also administers the Montana Water Quality Act and the Montana Pollutant Discharge Elimination Permit Program (MPDES). The MPDES permit contains water quality limitations and requires self-monitoring of effluent by the permittee. In addition, MDHES is responsible for how radioactive substances are handled in the state and for operating solid and hazardous wastes programs.

\section{Agency: Montana Department of Fish, Wildlife, and Parks (MDFWP) Statutory Authority: 2-15-3401 MCA}

The Montana Department of Fish, Wildlife, and Parks (MDFWP) is responsible for managing Montana's wildlife, state recreation lands, and state parks. MDFWP policy is set by the Montana Fish and Game Commission. MDFWP controls many types of land in Montana. Its authority over these lands exists under a number of arrangements including patent, deed, lease, easement, agreement, or withdrawal. MDFWP participates with other state and local agencies to obtain instream water reservations for fish and wildlife, and to review and permit projects under the Stream Preservation Act. MDFWP reports to other state agencies on the impacts of major energy or other types of facilities on fish and wildlife resources. MDFWP advises other state and federal agencies on the potential impacts of energy-related activities, such as coal, geothermal, oil, and gas leasing development. MDFWP also participates in the state's review of proposed new hydroelectric projects. 


\section{Agency: Montana Department of Natural Resources and Conservation (MDNRC); Board of Natural Resources (BNR); Board of Oil and Gas Conservation (BOGC) Statutory Authority: 2-15-3301 MCA}

The Montana Department of Natural Resources and Conservation (MDNRC) executes statutory responsibilities concerning the state's land, water, and energy resources. MDNRC administers a wide range of state and federal programs dealing with renewable energy and energy conservation. It is also responsible for preparing environmental impact statements for projects that fall under Montana's Major Facility Siting Act and projects for which MDNRC is designated the lead agency under the Montana Environmental Policy Act. MDNRC has a broad array of responsibilities associated with the uses, development, and protection of Montana's water. The Board of Natural Resources and Conservation (BNRC) has authority to approve reservations of water under the Montana Water Use Act and to approve the siting of energy facilities under the Major Facility Siting Act. In addition, the Board of Oil and Gas Conservation (BOGC), which is administratively attached to the MDNRC, administers laws regulating the drilling and recovery of Montana's oil and gas resources.

\section{Agency: Montana State Historic Preservation Office (MSHPO) Statutory Authority: 2-15-1512 MCA}

The Montana State Historic Preservation Office (MSHPO) is responsible for cooperating with and advising other state agencies when potentially valuable historical, archaeological, or other cultural resources are located in a project area (Montana Antiquities Act and the National Historical Preservation Act). Part of the advice given to other agencies may include comments on an applicant's plan for impact mitigation of sites eligible for nomination to the National Register of Historic Places. SHPO is also responsible for issuing antiquities permits for projects on state lands.

\section{Agency: Public Service Commission (PSC)}

Statutory Authority: 69-1-102 MCA

Montana's Public Utilities Regulation Law (69-3-101, MCA) defines a public utility as: ...every corporation, both public and private, company, individual, association of individuals..., that now or hereafter may own, operate, or control any plant or equipment, within the state, for the production, delivery, or furnishing for as to other persons, firms, associations, or corporations, private or municipal, heat,...power in any form or by any agency, water for business, manufacturing, household use... whether within the limits of municipalities, towns, or villages, or elsewhere.

The Public Service Commission (PSC) is a five-member elected body with the responsibility to ensure that public utilities provide adequate service to customers at reasonable rates. It's jurisdiction generally includes private, investor-owned natural gas, electric, telephone, and water companies doing business in Montana. In addition, the PSC regulates intrastate railroads and 
certain motor carriers, oversees natural gas pipeline safety regulations, and has limited authority over municipal utilities's rate increases. The PSC must approve utility rates, including those for Qualifying Facilities (QF).

\section{Agency: Montana Department of Transportation (MDT) Statutory Authority: 2-15-2501 MCA}

The Montana Department of Transportation (MDT) is responsible for all modes of transportation. The Highway Division constructs, maintains, and protects the state highway and bridge system. It also grants right-of-way easements for utilities and property access. In addition, it manages the state motor pool and the roadside rest areas, and enforces the state Outdoor Advertising Control Act. The Aeronautics Division enforces aeronautics safety rules and cooperates with federal authorities on civil aviation matters; it also manages state-owned airports and navigational beacons. The Rail and Transit Division is responsible for public transportation coordination and rate analysis and litigation. The Motor Transport Services Division enforces commercial vehicle weight and dimension laws, licensing, permitting, and fee collection on motor transport fuel taxes.

\section{Agency: Montana Department of State Lands (MDSL) Statutory Authority: 2-15-3201, MCA}

The Montana Department of State Lands (MDSL) has four basic functions: management of the lands held by the state of Montana in trust for the support of the common schools and other institutions; regulation of mining conducted on private, state, and federal lands; fire prevention and suppression on certain private, state, and federal lands; and regulation of and assistance to private forest land owners. The state now holds approximately 5.2 million acres of surface and 6.2 million acres of mineral land, primarily for the common schools. In managing this land, the Department must obtain the highest long-term monetary return.

\section{Agency: Montana Department of Labor and Industry (L\&I) Statutory Authority: 2-15-1701, MCA}

The Montana Department of Labor and Industry (L\&I) serves as an employment agency, collects and disburses state unemployment funds, provides training, and oversees federal Job Training Partnership Act (JTPA) grants. The Department also enforces state wage and hour laws, provides for apprenticeships, administers the state's industrial safety laws, holds contractor bonds, hears disputes on state employee relations, unemployment insurance, and Workers' Compensation, enforces state and federal antidiscrimination in employment laws, and assists the public in the interpretation of the Worker's Compensation and Occupational Disease Acts. 


\section{Agency: Montana Department of Commerce (MDC) \\ Statutory Authority: 2-15-1801, MCA}

The Montana Department of Commerce (MDC) is the state's lead economic development agency, providing technical and financial assistance to business, as well as state planning for economic development. The International Trade Office, the Census and Economic Information Center, and the Small Business Development Center, which works in conjunction with the federal Small Business Administration, are located in the Business Development Division. The Board of Investments manages state funds and issues loans from the state Coal Severance Tax Trust Fund. The Science and Technology Alliance manages a capital financing program that provides seed money, supports research and development projects, and in general works with venture capital. The Building Codes Bureau is located in the Department, as are the different professional and occupational licensing boards, such as for architects and engineers. The Department also is responsible for tourism, local government assistance, consumer affairs, low-interest housing loans, and Indian affairs.

\section{Montana State Permitting and Licensing Requirements}

This section serves as a guide for satisfying the state and local requirements for construction of a geothermal generation facility in Montana. These requirements are concerned with a wide variety of issues such as legal rights, public safety, and environmental concerns and many apply to other types of projects in addition to geothermal development.

Although numerous agencies have potential permitting or review authority, geothermal projects are likely to require only a few permits. Nevertheless, the time required for obtaining all permits and licenses may be a substantial part of the total project duration. It is therefore important for the site developer to initiate the permitting process in the early stages of project development. Specific time requirements may be found in the sections describing the individual permits.

In spite of appearing as a series of barriers to developers, the permitting process may actually be beneficial. By consulting with appropriate agency officials during the preliminary design and analysis phase, potential problems with a particular site or design can be spotted early. Appropriate modification can then be made, thus avoiding last-minute delays.

In Montana, a geothermal developer will at least have to obtain a water rights permit from the Montana Department of Natural Resources and Conservation (MDNRC). Some projects also require a Montana Major Facility Siting Act Certificate. The granting of this certificate is under the jurisdiction of the Board of Natural Resources and Conservation.

Other state agencies that may require permits or otherwise act in a review capacity include: Montana Environmental Sciences; Montana Department of State Lands; and Montana Department of Fish, Wildlife and Parks. Requirements of each agency are summarized below. 


\section{Major Facility Siting/Environmental Impact}

\section{Permit or Regulation: Certificate of Public Need and Environmental Compatibility \\ Statutory Authority: Major Facility Siting Act, 75-20-101 et seq., MCA \\ Agency: Montana Department of Natural Resources and Conservation (MDNRC); Board of Natural Resources and Conservation (BNRC)}

The Montana Major Facility Siting Act provides for comprehensive review of proposals to construct and operate certain kinds of facilities for generating, converting, or transmitting energy in Montana (Figure 13). To minimize the impacts of such facilities, the Board of Natural Resources and Conservation (BNRC) must certify public need for and environmental compatibility of such facilities before construction begins.

The Act applies to the following types of generation, conversion, and transmission facilities:

1. facilities that can generate $50 \mathrm{MW}$ or more of electricity

2. facilities that can use, refine, or convert 500,000 tons of coal or more per year

3. electric transmission lines and associated facilities of more than 69 kilovolts $(\mathrm{kV})$, except

a. lines of $230 \mathrm{kV}$ or less and 10 miles or less in length

b. lines of more than $69 \mathrm{kV}$ and up to and including $115 \mathrm{kV}$ for which the person planning to construct the line has obtained right-of-way agreements or options for a right-of-way from more than 75 percent of the owners who collectively own more than 75 percent of the property along the centerline

4. facilities for developing and using geothermal resources capable of producing 25 million Btu per hour or more

Associated facilities such as transportation links, aqueducts, diversion dams, transmission substations, and other facilities associated with the production or delivery of energy are included. Federally-owned or controlled facilities located on federal lands must satisfy the substantive criteria of the Siting Act.

Certification is also required from the Environmental Sciences (MDHES) to ensure that the facility will not violate air and water quality standards or other laws administered by MDHES. Both MDNRC and MDHES must accept an application as complete before the evaluation process can begin. Application must be made on forms supplied by the departments.

Application for facilities filed under the Act must include a description of the proposed facility, with discussion of alternative sites, an explanation of need for a utility facility, and a filing fee, based on the estimated construction cost of the facility, to finance the state's evaluation. 


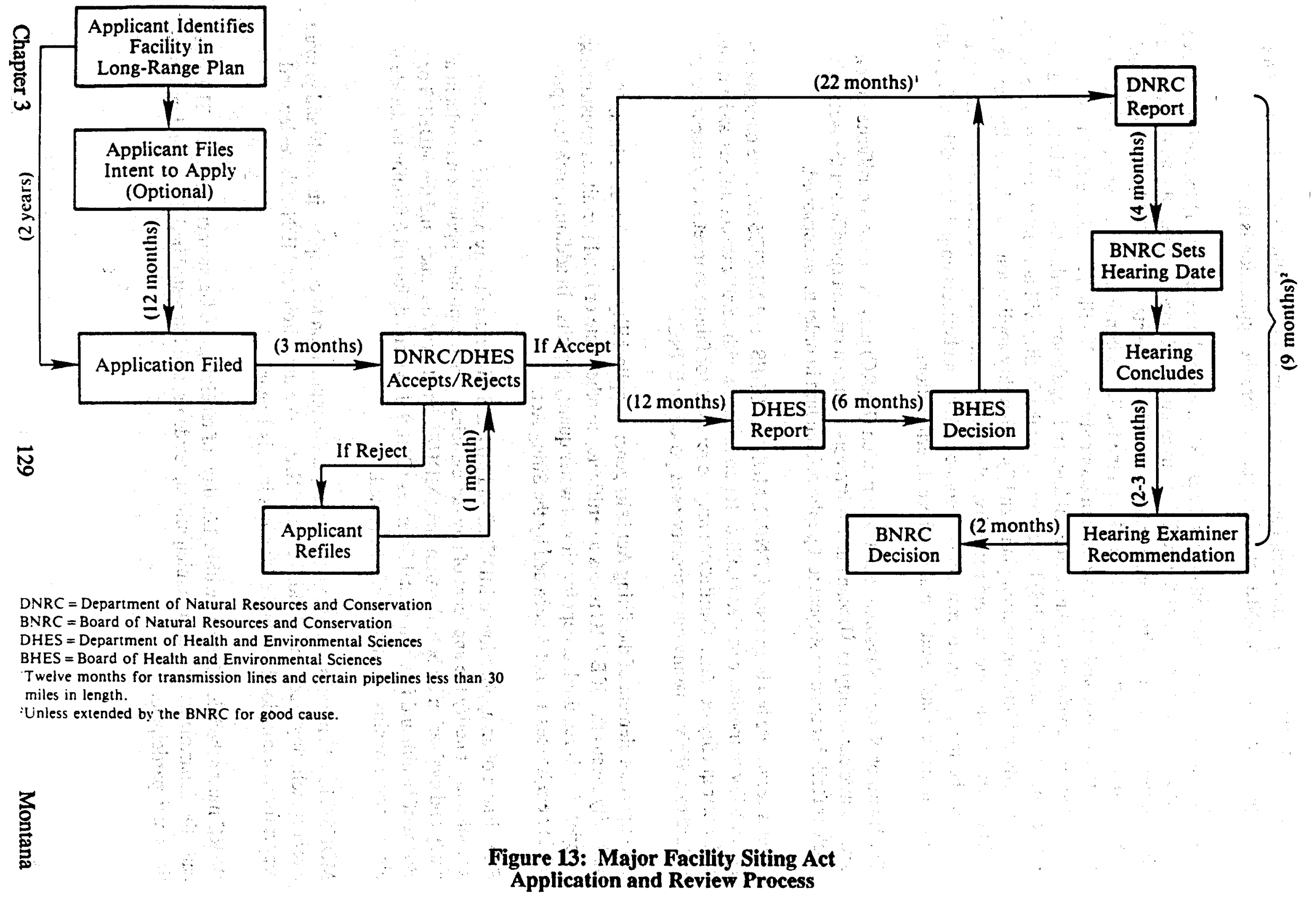


MDNRC and MDHES may not accept an application unless the facility is identified in a longrange plan submitted to MDNRC at least 2 years before the application is filed.

A certificate may not be granted unless the BNRC finds and determines: 1) the basis of the need for the facility; 2) the nature of the probable environmental impacts; 3 ) that the facility represents the minimum adverse environmental impact, considering the state of available technology and the economics of various alternatives; 4) that the facility is consistent with regional plans for expanding utility grids and will serve system economy and reliability; 5) that the facility's proposed location conforms to state and local laws and regulations; 6) that the Board of Health and Environmental Sciences (BHES) has certified that the facility will not violate air and water quality standards and implementation plans; and 7) for a utility application, that the facility serves the public interest, convenience, and necessity. Need, environmental impacts, benefits to the applicant and the state, effects of resulting economic activity, and effects on public health, safety, and welfare must be considered in making these determinations.

The Board of Natural Resources and Conservation (BNRC) may not issue a certificate to construct a nuclear facility in Montana unless it meets stringent criteria specified in the Act. All nuclear facilities must be subject to a public referendum in order to be approved.

After a certificate has been issued, BNRC, MDNRC, BHES, and MDHES all have ongoing responsibility to monitor certified facilities for compliance with certificate conditions and with air and water quality permits. Certificates may be revoked for failure to meet safety standards or failure to comply with any other conditions imposed by BNRC.

An important element of the Siting Act is its general applicability over other state laws. This authority means that if BNRC issues a certificate, no other state or local permit for construction or operation is required, except for air and water quality permits. In addition, such laws protecting employees are not superseded by the Siting Act.

Submission of an application to MDNRC and MDHES triggers a 90-day period in which the agencies must notify the applicant of any deficiencies. An acceptable application results in a study and evaluation by both departments. MDHES has 1 year for study and the MDHES or Board of Health and Environmental Sciences (BHES) have an additional 6 months to decide if air and water quality permits should be issued.

MDNRC has 22 months from the date it accepts the application to complete its study and prepare a report including recommendations to the BNRC. The time limit for MDNRC's review and report for transmission lines under $\mathbf{3 0}$ miles long is 1 year.

BNRC must schedule a hearing within 120 days of receiving the Department's report. The applicant, the departments, affected municipalities, residents, and interested individuals and organizations may participate. 


\section{Approximate Time Required for Processing}

The entire hearing process, from the date of the Department's report to the BNRC until the hearing examiner's report is filed, may not exceed 9 months unless the BNRC extends the time for good cause. The BNRC must make its decision within 60 days after the hearing examiner's report is submitted.

\section{Permit or Regulation: Montana Environmental Policy Act Statutory Authority: 75-1-101 et seq., MCA Agency: Varies by Project}

Before any major action significantly affecting the quality of the environment is taken, a state agency must prepare an environmental impact statement (EIS) discussing the environmental impacts of the proposed action (Figure 14). An agency may, however, prepare a preliminary environmental review (PER) to determine whether an EIS is necessary. If the need for an EIS is clear, the PER step may be bypassed. If the PER indicates no potential significant environmental impact, an EIS need not be prepared and the agency may proceed with the proposed action. The EIS requirement applies to issuance of state permits, licenses, and approvals for private actions that will have significant environmental impacts. When a single project requires permits from two or more agencies, a lead agency will be designated to collect the EIS fee and to coordinate preparation of the document.

Copies of the EIS and the comments and views of the appropriate state, federal, and local agencies that are authorized to develop and enforce environmental standards must be made available to the Governor, the Environmental Quality Council, and the public and must accompany the proposal through the agency review processes. Alternatives to the proposal, irretrievable commitments of resources, and the relationship between short-term uses of the environment and long-term productivity must be discussed in the EIS.

\section{Approximate Time to Obtain EIS Approval}

If an EIS is necessary, the agency must prepare a draft EIS that is circulated to other agencies and to the public for comment. At least 30 days are allowed for comment with the possibility of a 30 day extension. A public hearing may be held after publication of the draft EIS. The agency is required to hold a hearing if a certain level of citizen interest is demonstrated.

A final EIS will be prepared if necessary, incorporating responses to comments on the draft and comments received at the hearing if one was held. Final action on a permit may not be taken sooner than $\mathbf{4 5}$ days after publication of the draft EIS nor sooner than 15 days after publication of the final EIS. 


\section{Air Quality}

\section{Permit or Regulation: Air Quality Permit}

Statutory Authority: Montana Clean Air Act, 75-2-101 et seq., MCA

Agency: Environmental Sciences (MDHES)

A permit from the Environmental Sciences (MDHES) is required for the construction, installation, and operation of equipment or facilities that may directly or indirectly cause or contribute to air pollution. Exceptions include sources that emit less than specified amounts (e.g., ventilating systems, motor vehicles). An air quality permit to construct or operate a new or altered air pollution source cannot be issued unless the source is able to comply with the ambient air quality standards, emission limitations, and other rules adopted under the Montana Clean Air Act, and the applicable regulations and requirements of the Federal Clean Air Act.

\section{Permit or Regulation: Prevention of Significant Deterioration}

Statutory Authority: 75-2-102, et seq, MCA

Agency: Board of Health and Environmental Sciences (BHES)

When a major new source of air pollution is proposed in an area whose ambient air quality is better than the applicable standards, a more stringent review procedure may apply. Such a review may include 1 year of preapplication baseline data, control technology review, air pollution impact modeling, and other appropriate measures.

One may apply to the Board of Health and Environmental Sciences (BHES) for an exemption from applicable rules governing emissions. Such a variance may be issued if the BHES finds there will be no adverse impact on public health or safety, and that compliance with the rules would be an undue hardship on the applicant.

\section{Approximate Time Required for Review}

There is a $\mathbf{3 0}$ day review period to ascertain if application is complete and accurate. This is followed by a 60 day review period for the permit. If there are EIS concerns, this process could take considerably longer.

\section{Water Quality/Water Use}

\section{Permit or Regulation: Beneficial Water Use Permit}

Statutory Authority: Montana Water Use Act, 85-2-101 et seq., MCA Agency: Montana Department of Natural Resources and Conservation (MDNRC)

A Water Use Permit must be obtained from the Montana Department of Natural Resources and Conservation (MDNRC) for all beneficial uses. Beneficial uses include, but are not limited to, agriculture, domestic use, fish and wildlife, mining, industrial activity, municipal supply, power generation, and recreation. However, if the project is located outside the boundary of a con- 
trolled groundwater area, a permit is not required before appropriating groundwater by means of a well or developed spring with a maximum appropriation of less than 100 gallons per minute. (Notice of Completion of Groundwater Development Form No. 602 must be filed, however, to obtain a water right.)

If the developer has an existing water right or a permit, the law also requires a change authorization be obtained to change the place of use, purpose of use, place of storage, or point of diversion.

An Application for Beneficial Water Use Permit (Form No. 600), a Notice of Completion of Ground Water Development (Form No. 602), and an Application for Change of Appropriation Water Right (Form No. 606) may be obtained from the Water Resources Division, MDNRC, at the local county clerk and recorder's offices, or from any of the Water Rights Bureau offices located in Bozeman, Helena, Missoula, Kalispell, Havre, Glasgow, Lewistown, Miles City, or Billings.

\section{Approximate Time to Obtain Permit}

It is recommended that at least 6 months be allowed to process the permit or change of application request.

\section{Permit or Regulation: 310}

Statutory Authority: Natural Streambed and Land Preservation Act, 75-7-101, et seq., MCA Agency: Conservation Districts; U.S. Army Corps of Engineers (COE); Department of Fish, Wildlife, and Parks (MDFWP)

In applying for a 310 permit, the applicant must comply with the provisions set forth in the Natural Stream Bed and Land Preservation Act, which came into existence during the $1975 \mathrm{Leg}-$ islative Session with the passage of Senate Bill 310. The purpose of this act is to protect and preserve the natural perennial-flowing rivers and streams and the land and property immediately adjacent to them, to prohibit unauthorized projects and protect the use of water for any useful or beneficial purpose as guaranteed by the constitution of the state of Montana. The Act applies to all private individuals and corporations on private, state, or federal land.

Any physical alteration of a natural perennial flowing stream, its beds, or immediate banks requires approval from either the Soil and Water Conservation District Supervisors, the Grass Conservation District Supervisors, or the Board of County Commissioners. In addition, a permit is required from the Army Corps of Engineers (COE) for any dredge and fill activity or other work affecting "navigable waters." This may include dredge or fill activity in wetlands.

Before engaging in any project that may obstruct or alter a stream, a state or local government agency must notify the Montana Department of Fish, Wildlife, and Parks (MDFWP). The 
MDFWP must notify the applicant whether the project will adversely affect fish or wildlife habitat. The MDFWP may require modifications to the project. If agreement cannot be reached, an arbitration panel may be appointed by the district court.

Approximate Time to Obtain Permit

Allow 60 days to obtain the 310 Permit.

\section{Permit or Regulation: Geothermal Leases on State Land}

Statutory Authority: 77-4-101 et seq., MCA

Agency: Montana Department of State Lands (MDSL); Board of Land Commissioners (BLC)

The Board of Land Commissioners (BLC) may lease state-owned lands, including the beds of navigable streams and the beds of navigable bodies of water, for the purposes of prospecting, exploration, well construction, or production of geothermal resources.

Approximate Time to Obtain Lease

It will take from 6 to 8 months to obtain the lease.

\section{Land Use}

\section{Permit or Regulation: Floodplain and Floodways Permit}

Statutory Authority: Floodplain and Floodway Management Act, 76-5-101 et seq., MCA Agency: Montana Department of Natural Resources and Conservation (MDNRC)

Artificial obstructions and nonconforming uses within a designated floodplain or floodway require a permit from the local governing body or from the Montana Department of Natural Resources and Conservation (MDNRC) if local authorities have not adopted rules. Local governments may adopt land use regulations, including floodplain management regulations within sheetflood areas, that may restrict development. If local regulations are not adopted, MDNRC must enforce minimum standards adopted by the Board of Natural Resources and Conservation (BNRC).

\section{Approximate Time to Obtain Permit}

It will take approximately 60 days to obtain this permit.

\section{Permit or Regulation: Heritage Site}

Statutory Authority: Montana Antiquities Act, 22-3-421 through 442, MCA Agency: State Historic Preservation Office (MSHPO) and Land Management Agencies

State actions or state licenses, assisted, or permitted actions that have the potential to substantially alter heritage properties or paleontological remains on state-owned lands are regulated, as is excavation of heritage properties on state-owned lands. 
In consultation with the Montana State Historic Preservation Office (MSHPO), the land management agency is required to determine whether a proposed action may impact sites, structures, or objects on state-owned lands that qualify or would qualify as heritage properties. This may require completion of a systematic cultural resources inventory, recordation of a property likely to be harmed, consideration of alternative projects, special protective stipulations, project modifications, or denial of the project. Agencies may require applicants for permits or licenses to complete portions of this analysis.

\section{Approximate Time to Obtain Permit or License}

It will take 1 to 2 weeks to obtain this license.

\section{Permit or Regulation: Natural Areas (Land Use Limitations) \\ Statutory Authority: 76-12-101 et seq., MCA}

Agency: Board of Land Commissioners (BLC); Montana Department of State Lands (MDSL)

A natural area is one affected primarily by natural forces, with evidence of human activity at a minimum, and with outstanding natural features worthy of preservation. State-owned lands that are controlled or acquired by the Board of Land Commissioners (BLC) may be designated natural areas. Each area so designated is managed by a "managing entity" and will be subject to a master plan setting forth specific land use limitations and controls. If feasible, the state of Montana will hold the water and mineral rights in order to adequately protect the area.

\section{Permit or Regulation: State-Owned Lands (Permits, Leases, Easements)}

Statutory Authority: Title 77, Chapters 1-6, MCA

Agency: Montana Department of State Lands (MDSL), Montana Department of

Fish, Wildlife, and Parks (MDFWP), Montana Department of

Natural Resources and Conservation (MDNRC), and Other State Agencies

Activities on state-owned lands generally require permits, leases, or easements from the Department of State Lands (MDSL) and approval from the Board of Land Commissioners (BLC). In addition, Montana Department of Fish, Wildlife, and Parks (MDFWP) and the Montana Department of Natural Resources and Conservation (MDNRC), and other state agencies should be contacted for information regarding rules and procedures on lands owned or administered by those agencies.

Approximate Time to Obtain Permit, Lease, andlor Easement This varies by agency and property. 
Permit or Regulation: Easement on State School Trust Land

Statutory Authority: Title 77, Chapter 2, MCA

Agency: Board of Land Commissioners (BLC) or Montana Department of

State Lands (MDSL)

The Montana Department of State Lands (MDSL) is involved in the permitting process for development if the proposed project is on state school trust land. The applicant is required to obtain an easement from the MDSL. Two types of easements are available: "Permanent Easements" require the approval of the Board of Land Commissioners (BLC). "Temporary construction permits" along or adjacent to permanent easements may be granted by license agreement with the MDSL. An-other important factor is that the MDSL is required to obtain full market value for all easements on state lands. Thus, market value would have to be determined and sought.

\section{Approximate Time to Obtain Permit}

Applications requiring BLC approval take about 2 or 3 months for approval.

\section{Construction}

Permit or Regulation: Highway Encroachment/Easements

Statutory Authority: 7-14-2139, MCA

Agency: Montana Department of Transportation (MDT)

Permits are issued by the Montana Department of Transportation (MDT) for construction or maintenance of encroachments on or under highway rights-of-way. Encroachments include all private structures, devices, and facilities placed upon, over, or under the right-of-way. These include ditches, dikes, flumes, canals, or bridges and water, sewer, electric, natural gas, and communications lines. Written permission is required from the Board of County Commissioners for any excavation or construction across county highways. Permission for easements and encroachments on or across state highway rights-of-way may be obtained from the MDT.

Approximate Time to Obtain Permit

It generally takes 2 weeks to obtain this permit.

Permit or Regulation: Highway Utilities Easements

Statutory Authority: 7-13-2101, 4101, MCA

Agency: Montana Department of Transportation (MDT)

Utility facilities used to transport or distribute hydrocarbons, electric power, energy/communication signals, water, and sewage are authorized to occupy highway rights-of-way if they conform to certain standards as approved by the Montana Department of Transportation (MDT). City councils and boards of county commissioners grant similar approval along city streets and county roads. 
Approximate Time to Obtain Permit

It generally takes 2 weeks to obtain approval.

Permit or Regulation: Public Water Supply (License)

Statutory Authority: 75-6-101 et seq., MCA

Agency: Environmental Sciences (MDHES)

A water system serving 10 or more families or 25 or more persons for 60 days out of the calendar year must be approved by the Environmental Sciences (MDHES). Plans and specifications for public water supply wells must be approved, as well as plans for construction, alteration, or extensions of any water system or treatment facilities. Operators in charge of public water systems and treatment facilities must be licensed by MDHES.

\section{Permit or Regulation: Building Permit}

Statutory Authority: 50-60-101 et seq., MCA

Agency: Building Codes Bureau, Montana Department of Commerce (MDC)

All construction throughout the state must comply with the state building codes and permit regulations. If towns or counties adopt local building codes, enforcement is by local rather than state authorities. A permit must be obtained from appropriate authorities before construction can begin.

\section{Approximate Time to Obtain Permit}

Varies by town and/or county.

Permit or Regulation: Mechanical, Electrical, and Plumbing Permits

'Statutory Authority: 50-60-101 et seq., MCA (Mechanical)

50-60-602 et seq., MCA (Electrical)

50-60-501 et seq., MCA (Plumbing)

Agency: Montana Department of Commerce (MDC); Building Codes Bureau

A mechanical permit is required for the design, construction, installation, quality of materials, location, operation, and maintenance of: heating, ventilating, cooling, or refrigeration systems; incinerators; and other miscellaneous heat producing appliances.

An electrical permit is required for any electrical installation in any new construction or remodeling.

A plumbing permit is required for the installation, removal, alteration, or repair of plumbing and drainage systems.

The local building department may administer an enforcement program in lieu of the state program. 
Approximate Time to Obtain Permits

Each permit can be obtained in about 2 days time.

\section{Forest Areas}

Permit or Regulation: Slash Disposal/Timber Cutting (Permit)

Statutory Authority: 76-13-401 through 413, MCA

Agency: Montana Department of State Lands (MDSL)

A permit is required from the Montana Department of State Lands (MDSL), Forestry Division, for slash disposal, timber cutting, or timber stand improvements on private lands or right-of-way by public or private utilities.

Approximate Time to Obtain Permit

If you go into a local MDSL office, you may obtain the permit at that time. If it is done by mail, it will take approximately 2 weeks.

\section{Safety/Health}

Permit or Regulation: Montana Pollution Discharge Elimination System Permit and the Montana Groundwater Pollution Control System Permit

Statutory Authority: Montana Water Quality Act, 75-5-101 et seq., MCA Agency: Environmental Sciences (MDHES)

A permit from the Environmental Sciences (MDHES) is required to construct, modify, or operate a disposal system or to construct or use any outlet for discharge of sewage, industrial, or other wastes into state surface or groundwaters.

MDHES may authorize short-term exemptions from certain water quality standards for necessary construction or hydraulic projects that may have short-term water quality impacts.

The applicant for a water pollution discharge permit must file an application for a Montana Pollution Discharge Elimination System (MPDES) permit or a Montana Groundwater Pollution Control System (MGWPCS) permit no less than 180 days prior to the operation of a point source. The discharge of pollutants into state waters in excess of the MPDES permit's restrictions constitutes a violation of the permit.

\section{Non-Degradation}

If effluent limitations or other conditions are imposed on a discharge permit in order to maintain water quality at levels better than the applicable water quality standards as directed by the state's non-degradation policy, the permittee may petition the Board of Health for an exemption from such non-degradation requirements. 


\section{Approximate Time to Obtain Permit}

It should take approximately 180 days to obtain this permit.

\section{Permit or Regulation: Solid Waste Disposal (License)}

Statutory Authority: Solid Waste Management Act, 75-10-201 et seq., MCA Agency: Environmental Sciences (MDHES)

A license is required from the Environmental Sciences (MDHES) for disposal of solid waste and for the operation of a solid waste disposal facility. Sites are approved and licensed by MDHES and validated by local health officials. A preliminary environmental review (PER) is a necessary part of the solid waste application review process. Any person may apply to the Board of Health and Environmental Sciences for a variance from the rules.

\section{Approximate Time to Obtain License}

If application is complete and accurate, it could take from 4 months to 1 year to receive this license.

\section{Permit or Regulation: Hazardous Waste Disposal (Permit)}

Statutory Authority: Montana Hazardous Waste Act, 75-10-401 et seq., MCA Agency: Environmental Sciences (MDHES)

A waste meets the definition of hazardous waste if it is included in an EPA list of specific hazardous wastes or demonstrates any of the characteristics of ignitability, corrosiveness, reactivity, or toxicity under standard test procedures. All hazardous wastes may only be transmitted, stored, treated, or disposed of in a manner consistent with state and federal law. A permit from the Environmental Sciences (MDHES) is required to construct or operate a hazardous waste management facility. A preliminary environmental review (BFR) is a necessary part of the hazardous waste facility review process.

If it is determined that an application for a certificate under the Major Facility Siting Act will result in the generation, transportation, storage, or disposal of hazardous wastes, MDHES must conduct its review concurrently with the studies of air and water quality conducted under the provisions of the Major Facility Siting Act.

\section{Approximate Time to Obtain Permit}

If application is complete and accurate, it could take from 4 months to 1 year to receive this permit. 
Permit or Regulation: Boiler License

Statutory Authority: 50-74-101 et seq., MCA

Agency: Montana Department of Labor and Industry (L\&I)

All boilers must be licensed by the Montana Department of Labor and Industry (L\&I), Safety Bureau. In addition, all boilers installed and operated in Montana must follow the rules for safe construction, installation, operation, inspection, and repair of equipment as stated by the L\&I. The definitions and rules follow nationwide engineering standards as published by the American Society of Mechanical Engineers.

\section{Approximate Time to Obtain License}

To obtain a certificate of inspection, it will take approximately 2 weeks if there are no problems found. The boiler must then be reinspected on an annual basis.

\section{Other}

Permit or Regulation: Federal Energy Regulatory Commission (FERC) Certification Statutory Authority: Cogeneration and Small Power Production Facilities, 69-3-601, MCA Agency: Public Service Commission (PSC) and Federal Energy Regulatory Commission (FERC)

A cogeneration or small power production facility, e.g., geothermal, may be certified as a qualifying facility $(\mathrm{QF})$. To be a $\mathrm{QF}$, a facility must meet certain requirements as stated in Montana law: 1) produce electricity by the use, as a primary energy source, of biomass, waste, water, wind, or other renewable resource or any combination of those sources; or 2) produce electricity and useful forms of thermal energy, such as heat or steam, used for industrial, commercial, heating, or cooling purposes through the sequential use of energy known as cogeneration; 3 ) have a power production capacity that together with any other facilities located at the same site is not greater than $80 \mathrm{MW}$; and 4) be owned by a person not primarily engaged in the generation or sale of electricity other than electric power from a small power production facility.

The Federal Energy Regulatory Commission (FERC) controls the certification process for a QF. Facilities that are connecting to a utility can get interface guidelines from that utility. The Public Service Commission (PSC) determines rates and conditions of those rates for contracts between small power producers and the utilities under PSC's jurisdiction.

\section{Local Permitting and Licensing Requirements}

Within the framework of federal and state regulation, local governments perform duties which can have unique and significant impacts on energy project development. Local governments can set an example by financing and developing energy facilities themselves. They can encourage 
private development through information distribution and active recruiting of facilities. Cities and counties also regulate energy facilities. Below state-level citing thresholds, the jurisdictions are the primary development permitting authority. They set land use policy which controls the type and location of future development and affect construction techniques by enforcing building and electrical codes. They direct the division of lots through subdivision ordinances. They also regulate the type, mix, and location of land uses using zoning ordinances.

Zoning ordinances implement policies established in local land use plans and reduce land use conflicts by dictating: 1) the type of development allowed within the jurisdiction; 2) the design of those uses; and 3 ) the way potentially conflicting uses may coexist.

Policies and standards reflect both technical information and popular opinion. Local land use law often reflects values that are difficult to evaluate objectively. Public participation in a project approval may reveal concerns for property values, neighborhood quality, and scenic quality. These subjective values are difficult to put into laws. Few local governments have done more with energy facility regulation than provide a forum for public involvement in siting decisions.

In some states, counties and incorporated cities prepare and adopt comprehensive land use plans which are acknowledged by a state-level commission. The plans indicate the location and significance of affected resources and provide a regulatory framework for potentially using them. If a conflict is identified which is resolved against energy resource development, then another site must be found, unless the plan is amended. If the conflict is resolved in favor of energy resource development then, from a land use perspective, resource use is feasible. Development still may be subject to conditions which mitigate negative impacts. These requirements are described in the plan and local ordinances. Thus, developers can use comprehensive plans to learn what kind of projects might be feasible, and under what conditions.

Some counties discuss renewable resources in their comprehensive plans. However, discussion in the plans has often not led to zoning and ordinances. Frequently, adequate and up-to-date data on resources' location, quantity, and quality has not been given to local governments. Also, energy issues are not a priority in land use planning circles or most local governments.

In the absence of attention to the energy resource in the local land use plan, a prospective developer may have to champion a project proposal through the entire land use planning, zoning, and ordinance-writing processes. Such an effort would add many months to a project's lead time and increase its cost. Along the way, design changes are likely or the project may be found infeasible. The local government and public would be involved in broad planning, policy-making, and ordinance issues in the context of community reaction to a proposed project.

Local governments such as cities, counties, road districts, flood control districts, and drainage districts will have some jurisdiction over geothermal development in nearly all cases. Most county governments in Idaho require building permits for construction and entail building code, electrical code, and plumbing code compliance. Most counties also have planning and zoning 
commissions that will review project plans for compliance with comprehensive plans, zoning regulations, and needs for conditional or special use permits. Counties may also have some jurisdiction over construction in or near defined flood plains and over use of, or construction near, county highways. The county courthouse, the county zoning administrator, and the county highway district are the best contacts for determining what permits or approvals will be required.

If a proposed site is within a city's limits or within its area-of-impact, appropriate contact should be made with city officials regarding building permits, zoning regulations, flood plain construction, and highway usage. Contact the city hall of the nearest city for a determination of the required permits and approvals and jurisdiction.

Smaller communities often issue all permits through a single office, such as the Clerk. In some counties, one or more highway districts exist that are responsible for construction and maintenance of roads. These agencies will be the administrators of all permits/approvals having to do with public rights-of-way.

A number of these permits, mainly those administered by the Planning Department, will involve substantial discretionary action on the part of the decision makers, approval being based on conformance of plans with established criteria or standards. Therefore, these decisions will usually be made by elected or appointed officials (city councilmen, county commissioners, or planning and zoning commissioners). Another group of approvals will be based on the adequacy of technical plans. These will generally be the permits listed as being administered by the public works department and building department. Several items will be simply a matter of registration, including the business license and registration of proprietorship. The following is a general description of each of the permits and approvals which may be required.

\section{Determining Which Permits are Required}

To enable a developer to determine what local permits are necessary for a particular site, and for guidance in obtaining local permits, the following guidelines are provided.

- Determine with certainty within what local jurisdiction the project site lies. Assumptions about jurisdiction are often inaccurate. Even if a site is within the county, it is possible it may be within a city's Area of Impact, which would give the city certain jurisdiction over the project.

- Contact agency staff early to obtain information about permits and to discuss your plans. Go into their office in person to make personal contact and to show your commitment to expediting the permitting process.

- Determine what permits will be required for the proposed project; what information should be provided; the process that will be followed; and time frames, including submittal dates, hearing dates, and the time within which a decision can be expected. 
- Get copies of the applicable regulations so you can personally review them and the evaluation criteria. Ask questions if the written regulations vary from information the staff has provided.

- In the case of more discretionary permits, ask the staff about the likelihood of approval; also what might help to speed up the process and decision.

- Submit a complete application. Incomplete applications will result in processing delays.

- Attend all meetings where the application will be discussed. If there is no one to respond to questions, delays may occur or the permit may be denied.

\section{Air Quality}

Permit or Regulation: City or County Air Quality

Agency: Relevant Local Agency; Environmental Sciences (MDHES)

A city or county may administer its own air quality permit program in lieu of part or all the Environmental Sciences (MDHES) permit program.

\section{Land Use}

Permit or Regulation: Local Zoning and Land Use Regulations

Statutory Authority: Title 76, Chapter 2, MCA (Counties)

Title 76, Chapter 3, MCA (Municipalities)

Agency: Local Planning \& Zoning Department

Before commencing any development or activity, a person should determine if local zoning regulations exist. Under Montana law, cities, towns, and counties may adopt zoning regulations and establish zoning districts for the regulation of height and size of buildings, percentage of lot occupied, size of yards, density of population, location, and use of buildings, etc. If zoning exists, a permit for the development or activity may be required.

\section{Permit or Regulation: Soil and Water Conservation District Land Use Regulations}

Statutory Authority: 76-15-701 et seq., MCA

\section{Agency: Local Soil and Water Conservation Districts}

Lands located within a soil and water conservation district may be subject to land use regulations designed to conserve soil and water resources, and control erosion. Variances awarded upon demonstration of great practical difficulties or unnecessary hardship are allowed. 
Types of activities regulated may include the following: engineering operations for dams, dikes, ponds, ditches, fences, and other construction.

\section{Construction}

Permit or Regulation: Highway Encroachments Easements

Statutory Authority: 7-14-2139, MCA

Agency: Board of County Commissioners (BCC) andlor Montana Department

of Transportation (MDT)

Written permission is required from the Board of County Commissioners (BCC) for any excavation or construction across county highways. Permission for easements and encroachments on or across state highway rights-of-way may be obtained from the Montana Department of Transportation (MDT).

\section{Permit or Regulation: Overhead Lines}

Statutory Authority: 69-4-401 et seq., 69-4-601, 602, 7-13-4106, MCA

Agency: Local Planning \& Zoning Department

The city or town council may regulate erection of poles and cables within city limits. Persons moving buildings, equipment, or other structures that will require moving overhead lines must give the person responsible for operating the lines 10 days notice.

\section{Permit or Regulation: Highway Utilities Easements}

Statutory Authority: 7-13-2101, 4101, MCA

Agency: City Council, Board of County Commissioners (BCC), or Montana Department of Transportation (MDT)

Utility facilities used to transport or distribute hydrocarbons, electric power, energy communication signals, water, and sewage are authorized to occupy highway rights-of-way if they conform to certain standards as approved by the Montana Department of Transportation (MDT). City councils and boards of county commissioners grant similar approval along city streets and county roads.

\section{Permit or Regulation: Lakeshore Protection Permit}

Statutory Authority: 75-7-207 through 217, MCA

Agency: Relevant Local Agency

If the local government has adopted lakeshore protection regulations, a permit is required for any work that will alter the current or cross-sectional area of a navigable lake or its shore. Such activities include constructing channels or ditches; dredging the lake bottom to remove muck, silt, or weeds; ponding; filling; and constructing breakwaters or wharves and docks. A variance from local regulations may be obtained if an impact statement is prepared and a public hearing held. 
The proposed work must not: 1) materially diminish water quality; 2) materially diminish habitat for fish or wildlife; 3) interfere with navigation or other lawful recreation; 4) create a public nuisance; or 5) create a visual impact discordant with natural scenic values as determined by the local government, where such values form the predominant landscape elements.

If petitioned by 30 percent of the landowners with property abutting a lake, the Montana Department of Natural Resources and Conservation (MDNRC) may adopt and enforce regulations.

Permit or Regulation: Sewer System (Approval)

Statutory Authority: 75-6-101 et seq., MCA

Agency: Local Public Works Department

Approval from local agencies is required to construct, alter, or extend a public sewer system serving 10 or more families or 25 or more persons for at least 60 days out of the calendar year. Operators in charge of public sewer systems must be licensed by their local agency.

\section{Permit or Regulation: Building Permit}

Statutory Authority: 50-60-101 et seg., MCA

Agency: Local Building Department

All construction throughout the state must comply with the state building codes and permit regulations. If towns or counties adopt local building codes, enforcement is by local rather than state authorities. A permit must be obtained from appropriate authorities before construction can begin.

Permit or Regulation: Mechanical, Electrical, and Plumbing Permits

Statutory Authority: 50-60-101 et seq., MCA (Mechanical)

50-60-602 et seq., MCA (Electrical)

50-60-501 et seq., MCA (Plumbing)

Agency: Local Building Department

A mechanical permit is required for the design, construction, installation, quality of materials, location, operation, and maintenance of: heating, ventilating, cooling, or refrigeration systems; incinerators; and other miscellaneous heat producing appliances.

An electrical permit is required for any electrical installation in any new construction or remodeling.

A plumbing permit is required for the installation, removal, alteration, or repair of plumbing and drainage systems or parts thereof.

The local building department may administer an enforcement program in lieu of the state program. 


\section{Permit Summary Sheet OREGON}

\section{AIR QUALITY}

Energy Facility Siting Certificate

Air Contaminant Discharge Permit

Notice Constr/Approval of Plans

WATER QUALITY/WATER USE

Water Pollution Control Facility

Net. Pollutant Discharge Elimination Sys.

Gen. Permit Water Pollution Discharge Sources

Water Rights Permit

Hydroelectric Permit

Geothermal Well Permit

LAND USE

Lapd Use Compatibility Statement

State-Owned Lands (permits, leases, easements)

Soil and Water Conservation District Land Use

Regulations

Streambed/Streambank Alteration

Floodplains and Floodway Permits

Heritage Sites Permits

CONSTRUCTION

Building Permits

Mechanical, Electrical, and Plumbing Permits

Highway Encroachments Easements

Overhead Lines

Highway Utility Easements

FISH/WILDLIFE

Fish \& Wildlife Impact Eval.

FOREST AREAS

Timber Removal/Slash Disposal Permit

SAFETY/HEALTH

Dam Safety Construction/Operation

Permits

Boiler License

ENERGY FACILITY

Energy Facility Site Cert

Qualifying Facility Cert.

SOLID HAZARDOUS WASTE

Solid Waste Disposal License

Hazardous Waste Disposal Permit

\begin{tabular}{|c|c|c|c|c|c|c|c|c|c|}
\hline $\begin{array}{c}\text { Permitting } \\
\text { Agency }\end{array}$ & $\begin{array}{c}\text { Thermal } \\
\text { Rescurces } \\
<25\end{array}$ & $\begin{array}{c}\text { Thermal } \\
\text { Rescurces } \\
>25\end{array}$ & $\begin{array}{c}\text { Trans- } \\
\text { mission } \\
\text { Lines }\end{array}$ & $\begin{array}{c}\text { Hydro } \\
25\end{array}$ & $\begin{array}{c}\text { Hydro } \\
>25\end{array}$ & $\begin{array}{l}\text { Cogen- } \\
\text { eration }\end{array}$ & Wind & Biomass & $\begin{array}{l}\text { Geo } \\
\text { therm }\end{array}$ \\
\hline $\begin{array}{l}\text { EFSC } \\
\text { ODEG } \\
\text { ODEG }\end{array}$ & 2 & $\begin{array}{l}2 \\
2\end{array}$ & • & & 2 & $\begin{array}{l}2 \\
2 \\
2\end{array}$ & - & $\begin{array}{l}- \\
2 \\
2\end{array}$ & $\dot{2}$ \\
\hline $\begin{array}{l}\text { ODEG } \\
\text { ODEG } \\
\text { ODEG } \\
\text { OWRD } \\
\text { OWRD }\end{array}$ & $\dot{\bullet}$ & $\begin{array}{l}2 \\
2\end{array}$ & & $\begin{array}{l}2 \\
2\end{array}$ & $\begin{array}{l}2 \\
2\end{array}$ & 2 & 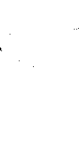 & 2 & \\
\hline
\end{tabular}

Geo-

ermal 


\section{Chapter 4 \\ The Oregon State Process}

\section{Legal Definition and Determination of Ownership}

\section{Definition}

The state of Oregon definition (ORS 522.055) of geothermal is, for the most part, based on the federal model. It reads as follows:

"Geothermal resource means the natural heat of the earth, the energy, in whatever form, below the surface of the earth present in, resulting from, or created by, or which may be extracted from the natural heat, and all minerals in solution or other products obtained from naturally heated fluids, brines, associated gases, and steam, in whatever form found below the surface of the earth, exclusive of helium or of oil, hydrocarbon gas or other hydrocarbon substances, but including specifically:

a) All products of geothermal process, embracing indigenous steam, hot water and hot brines;

b) steam and other gases, hot water and hot brines resulting from water, gas, or other fluids artificially introduced into geothermal formations;

c) heat or other associated energy found in geothermal formations; and

d) any by-product derived from them."

The state, however, distinguishes resources based upon temperature and depth. Hot water from wells less than $600 \mathrm{M}\left(2,000 \mathrm{ft}\right.$.) that have bottom-hole temperatures less than $120^{\circ} \mathrm{C}\left(250^{\circ} \mathrm{F}\right)$ must be developed according to state water law and are under the jurisdiction of the Department of Water Resources. All other wells require a geothermal well permit from the Oregon Department of Geology and Mineral Industries (ODOGAMI). Under Oregon law it is not necessary to know the bottom-hole temperature of wells before they are drilled because all geothermal prospecting is regulated under geothermal statutes. However, if water well temperatures approach $120^{\circ} \mathrm{C}\left(250^{\circ} \mathrm{F}\right)$ in the course of water resources development, a geothermal permit must be obtained from ODOGAMI.

Under Oregon law, geothermal is managed as water if it is below $120^{\circ} \mathrm{C}\left(250^{\circ} \mathrm{F}\right)$ and regulated by the Department of Water Resources. Geothermal is managed as a mineral resource if it is above $120^{\circ} \mathrm{C}\left(250^{\circ} \mathrm{F}\right)$ and under the jurisdiction of the Oregon Department of Geology and Mineral Industries. 


\section{Ownership}

The state of Oregon in the Geothermal Resources Act of 1975 (ORS 522.035) grants geothermal ownership rights to the surface owner. The Act states:

Ownership rights to geothermal resources shall be in the owner of the surface property underlain by the geothermal resources unless such rights have been otherwise reserved or conveyed. However, nothing in this section shall divest the people or the state of any rights, title, or interest they may have in geothermal resources.

\section{Obtaining Access to Geothermal Resources}

\section{State Lands}

The State Land Board, through the Oregon Division of State Lands (ODSL), is authorized to issue leases for geothermal resources underlying state-owned lands. A geothermal resources lease is required to explore, develop, or dispose of any state-owned geothermal resources.

However, casual exploration activities can be carried out before lease acquisition under a geothermal exploration permit issued by the ODSL. The procedure requires the applicant to submit a description of the exploration plan, evidence of compliance with insurance and bonding requirements, and other information deemed necessary. The permit is issued for a one year period and allows nonexclusive access to state land for geothermal exploration. An exploration permit does not give preferential right to lease.

To obtain a lease, an application must be filed with the ODSL with a nonrefundable $\$ 50$ fee and $\$ 1$ per acre advance rental fee. The minimum size lease is $\mathbf{4 0}$ acres.

Generally, applications are accepted on a first come, first served basis, although ODSL may favor an applicant with adjacent lands under lease. Leases may be issued by application or public drawing on noncompetitive land. ODSL administers cash bonus bid leases (a cash bid per acre over and above the minimum rental fee) on competitive lands classified as being a Designated Geothermal Resource Area based on geologic evidence and/or a producing geothermal well. To date, no areas have been so classified in Oregon by the ODSL.

To maintain lease application status, the applicant is required to submit, within 120 days of filing the application, a geologist's preliminary survey report and groundwater report, environmental impact report, evidence of compliance with insurance requirements, corporate surety bond of at least $\$ 10,000$, copies of permits issued by state or local regulatory agencies, and any other information required by ODSL.

Preparation of the Environmental Impact Report (EIR) is the responsibility of the applicant. The following information is required: 
- technical description of proposed geothermal operations

- common effects of all geothermal operations

- description of resources peculiar to the site involved

- possible means to mitigate adverse effects.

ODSL has prepared a statement to meet the first two requirements, and has issued instructions for estimating environmental impact.

The pre-lease environmental report is required to address the potential effects of proposed exploration, development, and production activities for the lease in terms of environmental and socioeconomic acceptability. The lease applicant pays for the assessment. Cost and time related to preparation of the EIR will vary depending on the scope of the proposed action.

ODSL also requires an archaeological survey before entry for exploration, a proposed program for monitoring and surveillance of the geothermal resource and groundwater quality and quantity during production, a program for subsidence monitoring, a revegetation plan for disturbed areas, and compliance with Oregon Department of Environmental Quality (ODEQ) standards governing air and water quality, noise, and waste disposal.

Upon receipt of the environmental impact report, ODSL will send copies to affected state agencies. All agencies are to respond within 60 days of the receipt of the environmental impact report. Agencies should recommend whether the lease should be granted and may, in addition, recommend conditions to be contained in the lease to satisfy requirements within their respective statutory jurisdictions.

If, after the appropriate public hearings, ODSL approves the application with the concurrence of the state agency controlling the surface rights, the application will be placed before the State Land Board for final approval.

ODSL may refuse to grant a lease for state-owned geothermal resource rights because of environmental quality or other public interest considerations.

ODSL offers consultation with the Oregon Department of Geology and Mineral Industries and with concurrence of any state agency acting for the state with respect to surface rights in the subject land. ODSL may execute leases and contracts for the development of geothermal resources under conditions agreed upon by ODSL and the lessee (ORS 273.551).

ODSL may withdraw any geothermal resource rights from availability for leasing or declare any geothermal resource rights to be within a designated geothermal resource area pursuant to OAR 75-520 through 75-575 at any time prior to the appraisal of a lease of such geothermal resource rights.

Leases will not be granted for tracts of land less than a quarter section (40 acres) without good cause. There is no maximum state holding per individual or company. 


\section{Competitive Leasing}

In order to establish priorities for effective development of the energy capability of geothermal resource rights owned by the state, ODSL may classify such geothermal resource rights as being within Designated Geothermal Resources Areas upon finding that a high probability of geothermal resource development exists.

ODSL may designate geothermal resource rights as being within a Designated Geothermal Resource Area:

1. upon receipt of notice of the discovery of geothermal resource under a geothermal resources lease, or upon learning that geothermal resources have been discovered on lands adjacent to state-owned geothermal resource rights

2. after conducting its own investigation of a particular area with reference to geothermal occurrences, either natural or man-made, geologic structures, present land uses, recreational potential, wildlife potential, geologic and geophysical test data, and other information of a factual natural.

\section{Establishment of Bidding Unit}

After establishing a Designated Geothermal Resource Area, ODSL will establish quadrants that divide that area into four bidding units of approximately equal size. Unleased geothermal resource rights within each bidding unit will be grouped for bidding purposes.

\section{Notice of Bidding}

ODSL will publish a notice of opportunity to bid for leases within the Designated Geothermal Resource Area in a newspaper of general circulation in the county or counties where the Designated Geothermal Resource Area is located. ODSL will provide written notice to any person or organization that has requested in writing that ODSL provide such notices to it directly.

The notice will specify the time and place of bid opening, how bids must be submitted, a description of the geothermal rights in each bidding unit, and terms and conditions including rental and royalty rates. The notice will also state that a proposed plan for reduction of environmental impacts and an environmental impact analysis of development and production alternatives will be required before a lease can be issued.

\section{Bidding Requirements}

Each bidder must submit with the bid: 1) an application to lease geothermal resource rights, 2) the filing fee required by OAR 75-040, and 3) a certified or cashiers check; bank draft, or money order in the amount of one-half of the amount of the applicant's bonus bid.

ODSL maintains the right to reject any and all bids submitted. Incomplete and non-conforming bids will be rejected and bonus bids will be retumed. 
If a lease is awarded, a lease form is sent to the successful bidder. The bidder must execute the form within $\mathbf{3 0}$ days of receipt, pay the first year's rental, and pay the balance of the bonus bid.

\section{Restoration of Bidding Units}

If no bids are received on a bidding unit, ODSL, at its discretion, may remove the Geothermal Resource Rights therein from the Designated Geothermal Resource Area and offer the lands for non-competitive Geothermal Resource Rights leasing.

\section{Leasing by Simultaneous Application}

From time to time, geothermal resource rights become available for leasing by ODSL because: 1) they are added or returned to the Geothermal Registry; 2) upon cancellation, relinquishment, surrender, or other termination of an outstanding geothermal resources lease; or 3) upon an order of the Director of ODSL. ODSL will offer such geothermal resource rights for leasing by public drawing. Additionally, applications received for the same geothermal resource rights in any single mail deliver will be awarded by following OAR 75-405, parts 4 and 5 .

The following procedures are employed in leasing geothermal resource rights by public drawing:

1. A notice of the geothermal resource rights available for leasing by public drawing is posted in ODSL offices and distributed to all persons who have informed ODSL in writing of their desire to receive such notice. The notice shall describe the geothermal resource rights available for leasing and state the application deadline date, which must be at least 30 days after the date the notice is posted.

2. Applications for the geothermal resource rights described in the notice must be submitted in sealed envelopes labelled "Simultaneous Filing date" on a form supplied by ODSL and must be accompanied by the filing fee required by OAR 75-040, the advance rental required by OAR 75-230, and a prepaid, stamped business reply envelope.

3. All applications for the leasing of such geothermal resource rights filed on or before the closing date stated in the notice will be considered to have been filed simultaneously. Such applications will be opened in ODSL's Salem office at 10:00 a.m. of the first business day following the closing date stated in the notice.

4. After reviewing each application for compliance with the requirements of these rules, ODSL will select the successful qualified applicant by a random drawing to be held in public. Unless otherwise noted in the notice for simultaneous filing, successful applicants will be required to comply with OAR 75-255 through 75-270 prior to receiving a geothermal resources lease. 
5. After awarding geothermal resource leases to the successful qualified applicants, ODSL will return all rental checks to the unsuccessful applicants, together with a list of the successful applicants.

\section{Lease Terms}

Leases have a primary term of 10 years commencing with the date of execution. Lease rentals are as follows:

$\begin{array}{cr}\text { Years 1-3 } & \$ 1 / \text { acre } \\ 4 & \$ 3 / \text { acre } \\ 5 & \$ 5 / \text { acre } \\ 6-10 & \$ 5 / \text { acre }\end{array}$

If the lessee discovers geothermal resources on the lease premises, ODSL and the lessee may negotiate a rental of less than $\$ 5$ per year, commencing with the annual rental payment following the discovered geothermal resource is achieved. Such reduced rental shall not be less than $\$ 1$ per acre per year.

A royalty on geothermal resource production of 10 percent must be paid upon the productive value of the geothermal resources produced under the lease each month and sold or utilized by the lessee.

A royalty of 5 percent of the gross sale price of all heavy metals, miscellaneous precipitates, and nonhydrocarbons sold, exchanged, or otherwise disposed of for value in any calendar month must be paid.

A royalty of 1 percent of the gross sale price of demineralized water sold, exchanged, or otherwise disposed of for value in any calendar month must be paid.

If royalties during any year of the primary term equal or exceed the annual rental due under the lease, the lessee may renew the lease for a subsequent 10 -year period.

Leases requiring renewal prior to achieving commercial production during the primary lease term may be renewed for a maximum additional term of 5 years if a geothermal discovery has been made or is deemed by the Director of ODSL to be imminent. The Director of ODSL may require the lessee to submit and implement a development plan and time table as an added condition of the extended lease.

\section{Inspection of Leased Premises}

ODSL may conduct scheduled and unscheduled inspections of operations conducted by the lessee under a geothermal resource lease upon receipt of a complaint related to the conduct of the lessee, of its geothermal resource exploration, development, or production. ODSL or any governmental official appointed to the task by it may make an investigation and collect facts and opinions. 


\section{Suspension of Operations}

Upon the occurrence of any of the following events, the Director of ODSL may issue an order suspending operation under a geothermal resource lease executed by ODSL.

1. Violation of the regulatory requirements of the Oregon State Division of Geology and Mineral Industries, the Oregon Department of Environmental Quality, the Division of Employment, Bureau of Labor and Industries, Workman's Compensation Department, Oregon Public Utility Commissioners, Department of Revenue, or other authority having jurisdiction, in excess of $\mathbf{3 0}$ days after notice in writing from any such agency. However, for requirements undergoing further consideration, reconsideration by such agency, or appeal to the courts of such agency's decision, continued operation of the leased premises will be allowed.

2. Any violation of the terms and conditions of a geothermal resources lease which, in the judgment of the Director of ODSL, jeopardizes the environmental, public health, welfare, or safety of the state of Oregon.

\section{Cancellation of Geothermal Resource Lease}

ODSL may begin to cancel a geothermal lease if:

1. A lessee is in continued violation of terms and conditions of the lease (including but not limited to the lease's requirement to exercise due diligence in exploring, developing, and operating under the geothermal resource lease) beyond 30 days after receipt of written notice of such violation from ODSL.

2. The lessee submitted false information in its application or in any other document required to be submitted to ODSL.

3. The lessee has changed its method of exploring, developing, or producing geothermal resources under the lease without first securing the approval of ODSL.

\section{Indian Lands}

In the 1850 s, a series of treaties were negotiated between the United States and a number of the Indian tribes.

In exchange for giving the United States title to most of their land, the Indians retained reservations for homelands as well as a right to continue hunting and fishing at their usual and accustomed places, both on and off the reservation.

All of the treaties were negotiated, executed, and ratified by Congress. In the ensuing decades, the treaties were interpreted by the federal courts. The court rulings followed earlier Supreme 
Court rules conceming Indian treaties and established several basic principals. Most fundamentally, the rights retained by the tribes are reserved rights, that is they are rights retained by the tribes at the time of treaty-making, and not given to them by the United States.

Each tribe that signed a treaty has a property right to the use of the resources in question. As a property right retained from before statehood, treaty rights are in the nature of easements on other real property interests.

Treaty rights have also been found by the federal courts to include an environmental right. For example, court decisions have forbidden actions that would inundate usual and accustomed fishing sites, dewater fish habitat, or degrade water quality to the detriment of the fishery.

Indian water rights stem from a 1908 Supreme Court decision which stated that when land was set aside for reservations, it was implied that water was also reserved for tribal uses. It does not matter if the water has been put to use or not, it is still reserved for use on the Indian reservation.

Though altered somewhat by subsequent court cases, the Winters Doctrine, as this decision is known, remains the basis for Indian water rights. The Winters Doctrine usually refers to direct water use, rather than the protection of instream flows for fish habitat. There are many Winters Doctrine-based water claim cases currently in state and federal courts. The outcome of these cases could have a profound impact on current Western United States water use.

In 1984 the EPA announced that it would "work directly with Indian tribal governments on a one-to-one basis." This policy recognizes tribal governments as sovereign entities with primary responsibility for reservation environmental issues, such as air and water quality and related matters. This means that the tribes can contract directly with the EPA to administer the Clean Water Act, the Clean Air Act, and similar environmental programs on their reservations (Brown, 1991).

Individual Indian lands (allotments) held in trust by the U.S. or tribal land held in trust by the U.S. can be permitted or leased for mineral development under authority of a March 3, 1909, act, Leases of Allotted Lands for Mining Purposes, or a May 11, 1938, act, Leases of Unalloted Lands for Mining Purposes, Duration of Leases, and the 1982 Indian Mineral Development Act. These acts are regulated by 25 CFR 211.212 , and 216, and by 43 CFR 3100 through 3590 . The Bureau of Indian Affairs (BIA) is responsible for exploration permit, lease approval, and administration. The BIA is responsible for operational supervision of prospecting and development.

Access to Indian lands for non-disturbing surface exploration requires written agreement between operators and Indian land owners. Surface disturbing activities, including prospecting and development, require approval by BIA and BLM. The point of first contact should be between the prospective operator and tribal governments. 
Finally, and perhaps most significantly, the tribes as govermmental entities have a right to manage their resources. This means that the tribes undertake all activities necessary to adequately manage the resource, including protecting the environment necessary to sustain the resource (see The Federal Process for additional information on Indian lands).

\section{Tribal Requirements}

Development on tribal reservation land may be subject to tribal laws not detailed in this guide. The appropriate tribal planning office should be contacted prior to conducting activities on tribal land. For a list of tribal contacts, see Appendix 1D.

When a project is on non-tribal lands but may affect treaty-reserved resources or areas of tribal significance, agencies have an obligation and responsibility to consult with tribal govemments during the project review process. Mitigation may be required to protect treaty rights.

Preventing damage to Indian graves or artifacts is required. Unlawful removal or mutilation of artifacts or burial sites is punishable as a felony.

\section{Private Lands}

Developable resources are often found on private lands. Accordingly, one of the first activities is to gain access. Access to private land can be obtained by sale, lease, permit, option, or any other mutual agreement with the owner of the surface property and geothermal estate.

Landowners may permit access prior to a lease or purchase option. This allows the developer to conduct agreed upon preliminary exploration activities. Such activities could include geological and geophysical investigations that are non surface disturbing and the drilling of temperature gradient holes. (A state well drilling permit is required for exploratory drilling on private land.) Additional federal, state, and/or local permits are required for continued development. These are covered in subsequent sections.

\section{Sales}

A landowner who sells property to a developer transfers all interest and control in the property and its geothermal resources for a fixed price. The landowner does not incur the risks of development. The developer pays the market value of the property, taking into consideration any value added by the resource. A landowner who is paid in full need not be concerned with the development. However, a landowner who is to be paid over time from the project's geothermal resource or electricity sales revenues may retain some control over the property and its development as security for future payment. A landowner who wants to use the property for farming or grazing can lease back the property sold to the developer. 


\section{Lease}

Instead of selling the property, the landowner may rent or lease it to the developer for a fixed term. In most instances, access to private land is obtained through a geothermal lease. Leasing terms generally include length of lease, royalty payments, lease fees, and stipulations governing exploration and development activities. Terms are often based on state and federal oil, gas, and geothermal leasing guidelines. A lease or rental agreement allows the landowner to retain some control over the development and use of the land.

\section{Option to Purchase or Lease}

Instead of an immediate purchase or lease, the developer can buy an option through paying the landowner a sum, usually a small percentage of the property value. The option holds the property off the market while the developer determines whether to make a final purchase or lease. The terms of the final purchase or lease are negotiated and set forth in an option agreement.

Two agreements are needed for the developer to obtain the right to purchase or lease the property later and the right to install testing devices or completing an exploration process: an option's agreement, and a short-term lease or license agreement. Either a license or lease allows the developer to use the land during the option period.

At the end of the option period, the developer must decide whether to purchase or lease the property at the price and terms in the option agreement, or to give up all interest in the land. An option assures that the developer can buy or lease the property for a set price in the future. For instance, the developer can buy an option to purchase or lease the property at a low price in 5 years. Tests may show that the property has valuable resources. The developer can exercise the option at the low price despite the increased value of the land. However, if tests show that the geothermal resource is less valuable than thought, the developer is not bound to buy or lease the property.

The landowner cannot accept a better offer during the option period. The option price should adequately compensate the landowner for keeping the property off the market. The value of an option right depends on the length of the option period and the strength of the resource. If more than one developer wants to buy an option, the competition will increase the value of an option.

\section{Right of First Refusal}

A right of first refusal is often confused with an option to purchase. Unlike an option, a right of first refusal does not set a price for the property. A developer who buys a right of first refusal merely obtains a right to match any offer to buy the property. Thus, a landowner who receives an acceptable offer from a third party would be required to communicate the offer to the developer. The developer then has the right to match the offer and obtain the property or allow the property to be purchased by the offeror. 
A landowner may specify that a right of first refusal does not apply to offers to purchase made by specific parties such as family members. This allows the landowner to transfer ownership within a family while granting a developer a right of first refusal on offers made by others.

If the area of interest is already under lease for other purposes such as farming or grazing, the developer must secure permission through easement from the lessee for surface access rights.

\section{Easement}

A developer can negotiate an easement for access with adjoining landowners. An easement is a right to make limited use of real property in airspace. A landowner can sell an easement granting the developer the right to use the space across and above the property. This grants a positive right. An adjoining landowner may also agree to restrict vegetation, structures, or other objects that would impair or obstruct transmission lines. This is called negative easement.

An easement may be perpetual or for a specified time. Once granted, a perpetual easement may not be terminated except as stated in the easement, by court decree based upon abandonment or changed conditions, or by agreement of the parties.

To be effective, an easement must be in writing and be recorded in county property records. A landowner who has granted an easement can sell the property but the new owner will be bound by the terms of the easement. Similarly, if the developer sells the property benefited by the easement, the new owner will be entitled to the same rights as the developer. This is what the law means when it says that the easement is appurtenant to the land and follows with the real property benefited and burdened by the easement.

Easements may also be granted for uses other than access to energy resources. The uses of the easement are stated in the easement. For instance, an owner of adjoining property may grant a developer an easement to cross the property to install and repair equipment or the right to erect and maintain transmission lines. Easements from several parties may be necessary to install transmission lines.

\section{Covenant}

When property is sold, restrictions may be placed in a purchaser's deed prohibiting certain uses of the land. A developer who acquires only part of a larger parcel can ask the landowner to agree that when other parcels are sold, the deeds will contain restrictive covenants prohibiting new owners from obstructing the developer's access.

Restrictive covenants that preserve access must be in writing and should be recorded. Recorded covenants bind successive purchasers of land burdened or benefited by covenants. 


\section{Permit or License}

The landowner may grant the developer a permit or license to use the land or airspace for a specified time or purpose. This right is generally revocable at the landowner's will and may not be transferred or assigned. The developer who acquires a personal license or permit does not acquire a legal interest in land that can be recorded or mortgaged.

\section{Contract Provisions}

Both the developer seeking access rights and the landowner interested in leasing resources would be wise to invest in competent legal advice. Consultation with a qualified accountant regarding royalty payments and applicable tax laws is also advised. Contracts for a purpose, such as oil and gas leasing, may not be appropriate for geothermal development. The parties should design a contract that meets their specific needs and time requirements of the project.

\section{Oregon State Agency Responsibilities}

\section{Agency: Oregon Building Codes Agency (OBCA) Statutory Authority: ORS Chapter 479}

The Oregon Building Codes Agency (OBCA) regulates geothermal energy projects through local building departments. In less populated areas, 11 OBCA field offices issue permits and conduct inspections.

Local building, electrical, mechanical, and plumbing permits ensure that facilities are built according to the codes adopted by the OBCA. Local officials issue permits and conduct inspections. Local building departments review construction plans to ensure that they conform to the fire, life, and safety provisions adopted by the Executive Department Office of the Fire Marshall.

Pressure vessels and permits for boilers must be obtained directly from the OBCA Boiler Section.

OBCA professional licensing and advisory boards list professional engineers, architects, and landscape architects licensed to practice in the state.

\section{Agency: Oregon Department of Energy (ODOE) \\ Statutory Authority: ORS Chapter 469}

The Oregon Department of Energy (ODOE) was established to provide comprehensive state leadership on energy planning and forecasting, to support research on alternate sources of energy, to be a central repository for energy data, to educate the public about energy problems and conservation, and to use private or federal funds to support these activities. 
The Department oversees three major programs: Energy Conservation; Policy and Resource Planning and Nuclear Safety; and Energy Facilities Siting. ODOE's Small Scale Energy Loan Program makes long-term, low-cost loans for projects that conserve or produce energy.

ODOE administers federal programs for energy conservation in schools, hospitals, public care, and local government buildings. It also provides staff support for the Energy Facility Siting Council. The director is responsible for supervising day-to-day functions of the department, supervising and facilitating work on siting as directed by the Energy Facility Siting Council, and adopting rules and issuing orders to carry out policy stated in ORS 469.010.

The director's office also is responsible for public information, writing and publishing a wide variety of handbooks and pamphlets for public distribution, maintaining film and publication lists, and public speaking engagements to convey state energy policy.

ODOE is divided into four divisions. The Nuclear Safety Division staffs the EFSC, discussed below. The Policy and Planning Division provides technical assistance to developers. The Conservation Services Division provides assistance to developers. The Business Energy Tax Credit Programs provides a 35 percent tax credit for businesses that install energy conservation, renewable resource, and recycling projects.

\section{Agency: Energy Facility Siting Council (EFSC) Statutory Authority: ORS Chapter 469}

The Energy Facility Siting Council (EFSC), established under provisions of the state Energy Facility Siting Act, claims jurisdiction over certain energy facilities on all lands, private, state, or federally owned.* Site certifications are required by EFSC for any geothermal power plant with a nominal electrical generating capacity of more than 25 megawatts; pipelines transporting geothermal fluids that are 6 inches or greater in diameter and 5 miles or longer in length; and high voltage transmission lines of more than 10 miles in length with a capacity in excess of 230,000 volts.

EFSC has adopted general standards that apply to all energy facilities and require the following mandatory findings: 1) need for the proposed facility based on energy demand and economic prudence; 2) protection of public health and safety; 3) environmental protection; 4) beneficial use of wastes and byproducts; 5) conformance with statewide planning goals and comprehensive land-use plans; 6) protection of historical and archaeological sites; 7) no infringement on existing water rights; 8) necessary expertise to operate, construct, and retire the facility; 9) reasonable assurance of obtaining the necessary funds; and 10) identification of foreseeable socioeconomic impacts in the vicinity of the proposed facility (OAR 345-74-025).

*The United States Department of the Interior Bureau of Land Management does not recognize EFSC authority over federal lands, but will make every attempt to coordinate and cooperate with EFSC on the siting of facilities within the state of Oregon (Mohorich, 1985). 
EFSC also has the power to conduct investigations into all aspects of site selection, to designate areas within the state as suitable or unsuitable for geothermal power plants, and to establish standards and promulgate rules that must be satisfied in order to obtain a site certification. The 1974 Oregon Legislature directed EFSC to designate areas unsuitable for geothermal power plants. The Council in 1975 ruled that because of high recreational use and lack of roads, geothermal power plants greater than $25 \mathrm{MWe}$ could not be constructed in Newberry Crater. Test drilling continued, but the ruling deterred development in this area, which has since been designated a National Monument.

A very important element of the state energy facility siting statutes, and a critical role of the implementing authority, is to provide for the coordination of permits and license applications through all state and local agencies affected by an application. Another important element is to coordinate with other agencies to make siting of all energy facilities a one-step process for applicants. This procedure saves both time and money, and ensures that all applications are handled and evaluated in a consistent manner. Once a siting certificate for a transmission or energy conversion facility is granted, all state and local agency permits and licenses must automatically be granted. Each permitting agency, however, retains the authority to enforce conditions and requirements of the permit or license issued. Examples of required permits include: drilling, conditional land use, construction, air emissions, and disposal of liquid or solid wastes.

\section{Agency: Oregon Department of Geology and Mineral Industries (ODOGAMI) Statutory Authority: ORS Chapters 516, 517, 520, and 522}

The Oregon Department of Geology and Mineral Industries (ODOGAMI) conducts geologic mapping and investigates Oregon's geologic resources and hazards; provides the public with technical and non-technical geologic education and information about Oregon; protects the environment by continued regulation of the exploration, production, and reclamation of minerals, oil, gas, and geothermal energy; and participates in public policy formulation on geologic and other natural resources issues.

The department is recognized as the state's major source of geological mining, oil, gas, geothermal, and geological hazard data. Accurate geologic information is provided to the public most effectively by publishing technical maps, reports, guidebooks, and brochures and by releasing data by electronic media. The Department's geologic library, in cooperation with Oregon State Library, functions as a specialized central repository for both published and unpublished geologic information on Oregon and adjacent states. Geologic information and expertise are made available in nontechnical form to a broad audience of citizens and tourists through preparation of educational materials that describe the natural heritage of the state.

The Department's Mines Land Reclamation Program is the lead coordinating agency for state mining regulation, which operates through an interagency team permit process. Exploration and operating permits and bonds are required to ensure reclamation of land disturbed by mining. 
Agency: Oregon Department of Environmental Quality (ODEQ)

Statutory Authority: ORS Chapter 454

The Oregon Department of Environmental Quality (ODEQ) reviews plans for geothermal energy projects to improve or maintain air, land, and water quality.

ODEQ issues permits for air emissions, water discharges, water or waste treatment, and solid waste disposal. Each permit lists operating conditions and pollution limits. ODEQ also enforces noise limits. There are no separate noise permits.

The state is divided into five ODEQ administrative regions (see Appendix 1D). There are also five Air Quality Maintenance Areas (AQMAs). These areas encompass metropolitan Portland, Salem, Eugene-Springfield, Klamath Falls, and Medford-Ashland. AQMAs contain nonattainment areas, where air quality does not meet one or more federal standards. Air emission limits are stricter for plants located inside AQMAs than in other areas. The Eugene-Springfield AQMA is managed by the Lane Regional Air Pollution Authority. All others are managed by ODEQ.

Developers should meet with the ODEQ regional office before starting any project. ODEQ can help estimate environmental impacts and tell which permits, or standards, apply to your project.

The regional offices are:

Headquarters and Northwest Region, Portland

(503) 229-5630

Willamette Valley Region, Salem

(503) $378-8240$

Lane County,

Lane Regional Air Pollution Authority, Eugene

(503) 686-7618

Southwest Region, Medford

(503) $776-6010$

Central Region, Bend

(503) $388-6146$

Eastern Region, Pendleton

(503) $276-4063$

\section{Agency: Oregon Department of Fish and Wildlife (ODFW)}

Statutory Authority: ORS Chapters 497, 498, 501, 506, 507, 508, 509, 511, 513

The Oregon Department of Fish and Wildlife (ODFW) consists of the Fish and Wildlife Commission, the director (appointed by the commission), and a statewide staff.

The commission formulates the general programs and policies of the state conceming the management and protection of fish and wildlife resources and establishes seasons, methods, and bag limits for recreational and commercial take of the resource.

The ODFW is headquartered in Portland with regional offices in Newport, Clackamas, Corvallis, Roseburg, Bend, La Grande, and Hines. Twenty district offices are also staffed at strategic loca- 
tions throughout he state. The ODFW operates a variety of facilities designed to enhance fish and wildlife resources, including 34 fish hatcheries, one game farm, numerous wildlife areas, public shooting grounds, hunting and fishing access sites, and several research stations.

\section{Agency: Executive Department/Fire Marshall Statutory Authority: ORS Chapter 476}

Local building departments review construction plans to ensure that they conform to the fire, life, and safety provisions adopted by the Office of the Fire Marshal. The division has 12 field offices.

\section{Agency: Advisory Committee on Historic Preservation (ACHP) Statutory Authority: ORS Chapter 390}

The Advisory Committee on Historic Preservation (ACHP) consists of nine members recognized professionally in the fields of history, architectural history, architecture, archaeology, and other disciplines as may be appropriate; one member representing the public at large; and one American Indian. The members are appointed by the governor.

The committee is charged with reviewing nominations to the National Register of Historic Places form the state of Oregon, and recommending approved nominations to the State Historic Preservation Officer pursuant to the National Historic Preservation Act of 1966. The committee also reviews the Statewide Plan for Historic Preservation.

\section{Agency: Oregon Public Utility Commission (OPUC) Statutory Authority: ORS Chapter 757}

The Oregon Public Utility Commission (OPUC) consists of three commissioners who regulate electrical and natural gas utilities, large water districts, telephone, and transportation industries. The OPUC must ensure that utilities provide consumers with adequate services at reasonable rates while earning a fair retum on their investment (ORS 756.772).

The OPUC assists geothermal energy projects with safety codes and electrical power contract regulations. Safety codes govern equipment designed to transport gas or generate electrical power for transmission. The OPUC has adopted the National Electric Safety Code (NESC). Plants that connect with utility systems must comply with the NESC. OPUC will provide advice to small power producers and utilities over interpretations of the code.

The OPUC Utility Program makes an independent assessment of all utility rate proposals. It will not allow a utility to pass on purchased power costs if the power sales agreement is unfair to ratepayers. Utilities may ask OPUC to review a power sales contract before they sign it. 
OPUC staff will provide help to the small power producer in understanding his rights in contract negotiations with a utility. If an impasse is reached in negotiating a contract, participants may file a formal complaint with the Proceeding Division.

\section{Agency: Oregon Department of Parks and Recreation (ODPR)}

Statutory Authority: ORS Chapter 390

The Oregon Department of Parks and Recreation (ODPR) is responsible for the acquisition, improvement, maintenance, and operation of Oregon's state park system. The system is directed by the state parks administrator through a headquarters staff in Salem and five regional park supervisors stationed throughout the state.

In addition to operating state parks, the division gives technical assistance to local government agencies on park matters, develops and maintains the Statewide Comprehensive Outdoor Recreation Plan, and administers the Federal Land and Water Conservation Fund matching grant program in Oregon. The division also administers several special programs.

\section{Agency: Oregon Water Resources Department (OWRD)}

Statutory Authority: Constitution, Article XI.D

The Oregon Water Resources Department (OWRD) administers Oregon laws concerning the use of surface and groundwater. A Water Policy Review Board is composed of seven members appointed by the governor and confirmed by the Senate. It establishes policy to conform with the Surface Water Code and the Ground Water Act.

OWRD permits allocate surface and groundwater and protect critical areas. Permits cover diversion of water, hydroelectric power siting, safety of dams, reservoirs, creation of irrigation districts, and ponding.

Distribution of the available water supply is carried out by 19 Watermasters (Appendix 1D).

If you intend to use or divert state protected water resources, consult your District Watermaster. Locate your project on the river basin map in the field office, and obtain a permit application form.

\section{Agency: Oregon Division of State Lands (ODSL)}

Statutory Authority: ORS Chapter 273; OAR 141, Division 75; Constitution Article XI

State Land Board: The State Land Board is composed of the governor, who serves as chair, the Secretary of State, and the State Treasurer. Under constitutional and statutory guidelines, the Board is responsible for managing the assets of the Common School Fund as well as for additional functions assigned by the Legislature. 
The Common School Fund was established as a constitutional trust when Oregon was admitted to the union on February 14,1859. At that time, the federal government granted to the state the 16th and 36th sections of every township or other lands "in lieu" of these sections to support the public schools. The fund's land base now includes:

- more than 600,000 acres of grazing and agricultural land

- 132,000 acres of forest land, including the Elliott State Forest in Coos and Douglas counties

- 800,000 acres of off-shore land and estuarine tidelands

- submerged and submersible lands of the state's navigable waterways

The Oregon Division of State Lands (ODSL) manages these lands. The Director is appointed by the Land Board.

In addition to its land and fiscal management functions, the Division provides a number of other public services, many of which are legislatively assigned. One such responsibility is administering the state's removal-fill law, which protects Oregon's waterways from uncontrolled alteration. The permit-review process involves coordination with the applicant, adjacent land owners, and natural-resource and land-use agencies from local through federal levels.

Other responsibilities of the ODSL include: leasing state-owned mineral rights for exploration and production of oil, gas, hard minerals, and geothermal energy; management of Tongue Point Marine Industrial Site in Astoria; maintenance of historical records related to early land transactions, including deeds, leases, and plats; performance of administrative functions for the Natural Heritage Advisory Council, established by the Legislature in 1979 to identify representations of the range of ecosystem types found in Oregon; and management oversight and performance of administrative services for the South Slough National Estuarine Reserve, established by the federal govemment in 1974 as one element of the Oregon Coastal Zone Management Program.

\section{Agency: Oregon Department of Forestry (ODF) Statutory Authority: ORS Chapter 526}

The Oregon Department of Forestry (ODF) is under the direction of the State Forester who is appointed by the Board of Forestry. The statutes direct the State Forester to act on all matters pertaining to forestry in the protection of forest lands and the conservation of forest resources.

These activities include: fire protection for 16 million acres of private, state, and federal forests (over one-half the forest lands in Oregon); the detection and control of harmful forest insect pests and forest tree diseases on 12 million acres of state and private lands; the rehabilitation and management of 785,300 acres of state-owned forest lands; and operation of a 15-million-tree forest nursery. The Department also administers the Oregon Forest Practices Act, Log Patrol and Log 
Brand Acts, Small Tract Optional Tax Law, forest land classification, forestry assistance to Oregon's 24,000 non-industrial private woodland owners, forest resource planning, and forest products marketing.

\section{Agency: Oregon Department of Transportation (ODOT) Statutory Authority: ORS Chapter 184}

Oregon Transportation Commission: The Commission develops and maintains state transportation policy and a comprehensive long-range plan for a multimodal transportation system, which encompasses economic efficiency, orderly economic growth, safety, and environmental activities. Transportation planning must use the potential of all existing and developing modes of transportation. The plan includes aviation, highways, public transit, rails, and bike paths.

Policies for the operation of the Department are established by the Commission in a manner consistent with ORS 184.610 to 184.640 . The Commission coordinates and administers programs relating to aeronautics, highways, motor vehicles, and public transit.

The Governor appoints the five members for 4-year terms, which expire June 30 of the years indicated. Members are appointed with consideration for the different geographic regions of the state, with one member being a resident of the area east of the Cascade Range. No more than three members can belong to one political party.

Highway Division: The Highway Division's mission is to design, build, and maintain quality highways and bridges. The state's system must be safe, cost effective, and provide efficient access throughout the state. It should be planned and maintained to complement Oregon's natural beauty and to help spur economic development. The Division maintains over 7,500 miles of paved highways in the state system. The Division serves the public locally through five regional offices, with headquarters in Salem.

\section{Oregon State Permitting and Licensing Regulations}

Every geothermal energy project will require one or more permits. These will include:

1. approval to drill test wells

2. planning the new facility or business

3. site approval(s)

4. approval(s) of plans to protect the environment

5. approval(s) to build the facility

6. inspections and approval(s) to operate the facility

For power plants larger than $25 \mathrm{MW}$, the developer must apply to the Energy Facility Siting Council. Sales contracts for electric power may be reviewed by the Oregon Public Utilities Commission. 
The Oregon Department of Environmental Quality (ODEQ) issues permits for air emissions, water discharges, and solid waste emissions. The ODEQ permit process is shown in Figure 14, and the approximate time required to obtain the required permits is shown in Figure 15. Noise can be regulated by requiring monitoring or a program to bring activities into compliance.

\section{Facility Siting}

\section{Permit or Regulation: Energy Facility Siting Certificate \\ Statutory Authority: ORS 469.300-469.631; OAR, Chapter 345 \\ Agency: Energy Facility Siting Council (EFSC)}

This certificate applies to power plants that produce more than $25 \mathrm{MW}$ of electricity. Prior to applying for a site certificate, applicants must submit a Notice of Intent (NOI). The NOI describes basic intention about the project and its impacts.

The Energy Facility Siting Council (EFSC) is the state's authority for siting major power plants. It regulates and monitors construction and operation. Figure 16 shows the EFSC site certification application process.

EFSC guides all permit applications. It coordinates project review by state and local agencies. Its final decision is binding on all state and local agencies. All interested persons and government agencies have access to the EFSC process. Energy facility siting includes a public hearing.

Each site certificate includes conditions for construction and operation. These conditions are proposed, debated, and adopted through a contested hearing.

An applicant pays the entire cost of EFSC's review. Fees depend on the level of review. The fee for notices of intent to file application ranges from $\$ 15,000$ to $\$ 25,000$. The application fee ranges from $\$ 90,000-\$ 150,000$. Fee payment is due when filing an application. After the review, fees will be returned or additional amounts levied, depending on actual costs. An annual fee based on regulation costs is established by the ODOE director and is assessed each operating year.

\section{Approximate Time to Obtain Permit}

It takes approximately 12 to 18 months after the complete NOI is filed to receive the site certificate. 




Figure 14: Department of Environmental Quality Permit Process Diagram 
Months Prior to Construction

Energy Facility Siting Certificate

Zoning or Land Use Permit

Land Use Compatibility Statement

ODEQ Air Quality: Notice of Construction and Approval of Plans

Air Contaminant Discharge Permit (ACDP) (May be up to 12 months if data required)

Water: National Pollutant

Discharge Elimination System (NPDES)

Water Pollution Control

Facility (WPCF)

Solid Waste Permit

$\begin{array}{llllllllllll}12 & 11 & 10 & 9 & 8 & 7 & 6 & 5 & 4 & 3 & 2 & 1\end{array}$






Figure 16: Energy Facility Siting Council Application Process Diagram 
Table 5

Summary of Air Quality Permits

Permit Required

Air Contaminant

Discharge Permit

(ACDP)

Notice of

Construction

and

Approval of Plans $\underline{\text { Site }}$

All

All

All

All
Fuel Product, Rate, Other Conditions

Any Any air quality problem

Any Equipment change causes emissions change

Any For sources not large enough

for ACDP as follows:

$400,000 \mathrm{BtuH}$ or more

None Air pollutants from any process

\section{Table 6}

Emission Standards and Regulations Included in an Air Contaminant Discharge Permit (ACDP)

Standards or Rules

Miscellaneous Rules

Performance

Standards

(NSPS)

Prevention of

Significant

Deterioration

(PSD)

Hazardous Air

Pollutants

EPA
Site Fuel

All

All

Outside

Areas

All
Any

Any

AQMA Non-attainment or Class I

Any

Any
Product, Rate, Other Conditions

Electric 250 million BtuH or more heat input

Emit more than 250 tons/year of any pollutant

Emit asbestos, mercury, beryllium or other specified by ODEQ or

Permits must be renewed periodically. The ACDP can be issued for periods up to 10 years.

Five-year permits are typical.

Permit conditions can include:

a. limits on total suspended particulates (TSP) released per year, or within any 24 hour period

b. limits on other pollutants

c. requirements to maintain pollution control equipment

d. requirements to notify ODEQ of process upsets that would temporarily increase emissions 
e. requirements to reduce emissions in case of air pollution emergencies, "emergency episode plans"

f. monitoring, periodic measurement of specific pollutants

\section{Approximate Time Required to Obtain Permit}

It will take approximately 60 to 180 days to obtain a permit. A permit for large sources located near protected areas like a Class I or AQMA can take over a year.

\section{Permit or Regulation: Notice of Construction and Approval of Plans}

Statutory Authority: ORS Chapter 468; OAR 340, Divisions 20 and 30

Agency: Oregon Department of Environmental Quality (ODEQ)

Projects that are too small for an ACDP but may be significant sources of air pollution can be permitted under the Notice of Construction and Approval of Plans.

Approximate Time Required to Obtain Permit

It takes approximately 30 to 90 days to obtain permit.

Permit or Regulation: Miscellaneous Air Quality Rules

Statutory Authority: OAR 340, Division 20

Agency: Oregon Department of Environmental Quality (ODEQ)

Section -001: ODEQ may require a level of control known as "Highest and Best Practicable Treatment."

Sections -035 to -046: ODEQ may require almost any source to test the quality and quantity of its air emissions. An "indirect source" permit is necessary before construction.

Section -270: All fugitive and secondary emissions must be included in estimates of total emissions. The most common example of a secondary emission is road dust. Permit limits for "major" sources apply to fugitive and secondary emissions but they are not used to decide if a source is ranked as "major."

Section -300 to 310: A limit is set for total plant site emissions when new sources obtain permits. 
Permit or Regulation: Requirements for Sources in Non-Attainment Areas

Statutory Authority: ORS Chapter 46; OAR 340, Division 20

Agency: Oregon Department of Environmental Quality (ODEQ)

Air Quality Maintenance Areas (AQMAs) contain non-attainment areas where air quality does not meet federal standards. Rules for "major" sources locating in AQMAs keep new sources from interfering with Oregon Department of Environmental Quality (ODEQ) strategies to bring these areas into compliance with federal air quality standards.

"Major" air pollution sources have emission rates equal to or greater than those shown in Table 7, and for the Medford-Ashland AQMA the specific rates are shown in Table 8.

\section{Requirements}

If a project will be a "major" source, an ACDP will not be issued and construction cannot begin until conditions described below are met.

1. Emissions must be controlled to a level referred to as "Lowest Achievable Emission Rate" (LAER). This level is stricter than the "Best Available Control Technology" (BACT).

LAER is often the lowest rate any system has achieved for the pollutant in question.

2. All other "major" sources under the development ownership or control in Oregon must comply with air pollution limits under the Federal Clean Air Act.

Table 7

Significant Emission Rates

Pollutant

Carbon Monoxide (CO)

Nitrogen Oxides $\left(\mathrm{NO}_{\mathrm{X}}\right)$

Particulate Matter (TSP)

Sulfur Dioxide $\left(\mathrm{SO}_{2}\right)$

Volatile Organic Compounds (VOC)

Lead

Mercury

Beryllium

Asbestos

Vinyl Chloride

Fluorides

Sulfuric Acid Mist

Hydrogen Sulfide $\left(\mathrm{H}_{2} \mathrm{~S}\right)$

Total Reduced Sulfur (including $\mathrm{H}_{2} \mathrm{~S}$ )

Reduced Sulfur Compounds (including $\mathrm{H}_{2} \mathrm{~S}$ )
Significant

Emission Rate

(tons/yr)

100

40

25

40

40

0.6

0.1

0.0004

0.007

1

3

7

10

10

10 


\section{Table 8}

Specific Emission Rates in Medford-Ashland AQMA

Pollutant

TSP

VOC
Tons/Year

5.0

20.0
Pounds/Day

50.0

200.0
Pounds/Hour

10.0

3. It must be shown that there is room in the air shed for the source's emission. The project must comply with the established "growth increment" for the area. If a non-attainment areas has no growth increment the project developer will need to find "offsets," and reduce emissions from other sources.

4. Where growth increments exist:

a. no single source can use more than 50 percent of the increment remaining

b. a source can use "offsets" to stay within the growth increment

c. if a source can find offsets, it may not use part of an area's growth increment

d. when offsets are necessary, "net air quality benefit" standards and "reasonable further progress" criteria must be met. Consult the ODEQ

5. A new or "major" source of carbon monoxide (CO) or volatile organic compounds (VOC) must evaluate alternative locations, plant sizes, processes, and control techniques. The benefits of the controlled source must significantly outweigh the environmental and social costs of other alternatives.

6. Major sources of VOC in the Salem Ozone Non-attainment Area must meet conditions 1 and 2, but are exempt from conditions 3,4 , and 5 .

Since non-attainment areas rules are complex, the developer should meet with ODEQ staff.

ODEQ must notify other government agencies and the public of the application, the project's impacts, and their final decision. There may be a public hearing or written public comment.

\section{Approximate Time Required to Obtain Permit}

ODEQ must act on a complete application within 6 months. If monitoring is needed, it may take 9 to 12 months to complete the application. 
Regulation: Prevention of Significant Deterioration (PSD)

Statutory Authority: ORS Chapter 468; OAR 340, Division 20

Agency: Oregon Department of Environmental Quality (ODEQ)

Prevention of Significant Deterioration (PSD) rules prevent the decline of air quality where it is better than federal health and welfare standards in Class I wilderness areas, and in non-attainment areas found within AQMAs (Figure 17).

PSD rules control new or modified "large" sources outside of AQMAs and Class I areas that have a major impact on these areas. PSD conditions must be met to obtain an ACDP prior to construction.

1. Large sources are sources which emit more than 250 tons per year of any pollutant.

2. Sources have an impact on non-attainment areas if they are located within $50 \mathrm{~km}(31.25$ miles) and if air quality will exceed levels shown in Tables 9 and 10. These levels apply only to the pollutants for which an AQMA is designated. If, for example, an area exceeds federal standards only for $\mathrm{CO}$ and TSP, having $\mathrm{NO}_{\mathrm{x}}$ impacts greater than those cited would not make the source subject to PSD rules. Consult with the ODEQ to verify applicability.

3. Sources locating within $10 \mathrm{~km}$ ( 6 miles) of a Class I area, that would have a 24-hour air quality impact of 1 microgram per cubic meter of particulates are also subject to PSD rules.

\section{Requirement}

Show that "Best Available Control Technology" (BACT) will be used.

Approximate Time Required for Processing

ODEQ must act on a completed ACDP application within 6 months. It can easily take up to 3 months to complete the application if monitoring is not needed, and 15 months if it is.

\section{Table 9}

\section{Maximum Pollutant Levels Allowed by PSD Rules}

Average

Measuring

Time

Annual

24-hour

8-hour

3-hour

1-hour
Micrograms per Cubic Meter

TSP $\quad \mathrm{NO}_{2}$

$\mathrm{CO}$

1.0

0.2

1.0

25.0
500

2,000 


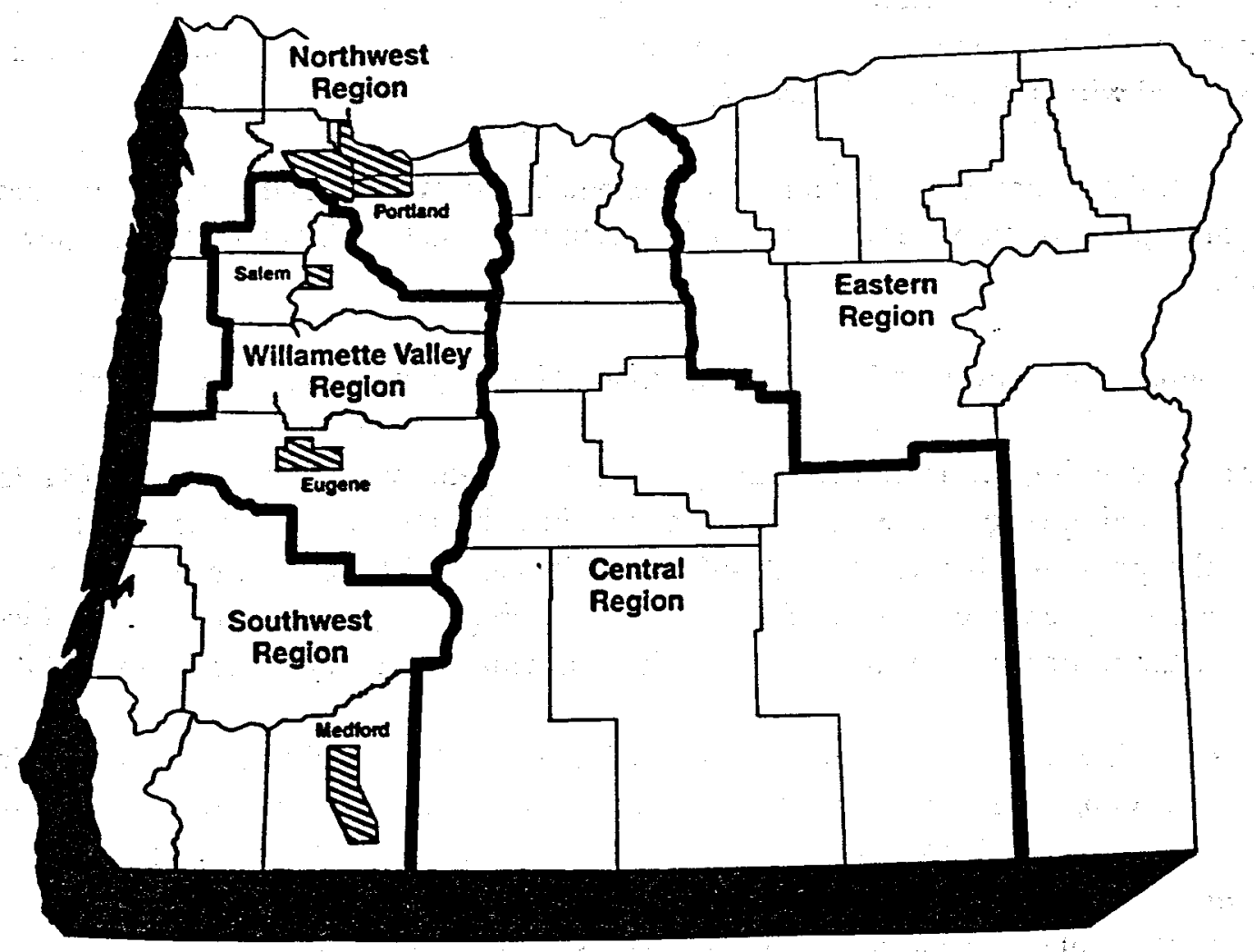

Air Quality Maintenance Areas

- Precise non-attainment area boundaries are different for various pollutants. Specific maps ane available from DEQ.

Figure 17: Oregon's Air Quality Regions and Air Quality Maintenance Areas 


\section{Table 10}

PSD Allowable Increments

Maximum Allowable Increase in Pollution Levels

in Micrograms per Cubic Meter

\begin{tabular}{lcc} 
Pollutant & $\begin{array}{c}\text { Class I } \\
\text { Areas }\end{array}$ & $\begin{array}{c}\text { Elsewhere } \\
\text { in Oregon }\end{array}$ \\
Particulate matter: & & \\
$\quad$ Annual geometric mean & 5 & 19 \\
$\quad$ 24-hour maximum & 10 & 37 \\
Sulfur Dioxide: & & \\
$\quad$ Annual arithmetic mean & 2 & 20 \\
24-hour maximum & 5 & 91 \\
3-hour maximum & 25 & 512 \\
\hline
\end{tabular}

Permit or Regulation: Emission Standards and Procedural Requirements for Hazardous Air Pollutants

Statutory Authority: ORS Chapter 468; OAR 340, Division 25

Agency: Oregon Department of Environmental Quality (ODEQ)

Sources of hazardous air pollutants are those which emit asbestos, mercury, or beryllium. The Oregon Department of Environmental Quality (ODEQ) or the Environmental Protection Agency (EPA) may add pollutants to this list.

ODEQ will generally cite OAR 340-20-001 for exotic emissions other than asbestos, beryllium, and mercury.

\section{Approximate Time to Obtain Permit}

ODEQ must act on a complete application within 6 months. If monitoring is needed, it may take up to 12 months to complete the application.

\section{Water Quality/Water Use}

The Oregon Department of Environmental Quality (ODEQ) issues two relevant water quality permits.

1. National Pollutant Discharge Elimination System (NPDES) permits cover all waste water discharges to surface waters. The NPDES is a federal program administered by the state. NPDES covers commercial or industrial plants, municipal sewage treatment plants, confined animal feed operations with point discharges, and mining operations. 
2. Water Pollution Control Facility (WPCF) permits apply to waste waters directly disposed of on land or injected into the ground with no direct discharge to surface waters. Land irrigation, evapo-transpiration lagoons, and industrial seepage pits are examples. WPCF is a state program.

\section{Permit or Regulation: National Pollutant Discharge Elimination System (NPDES)}

Statutory Authority: OAR 340-45-005--340-45-070; ORS 468

Agency: Oregon Department of Environmental Quality (ODEQ)

Any project that will release wastes into public waters will need a National Pollution Discharge Elimination System Permit unless:

1. The discharge is into a sewage system that has valid permits, such as a municipal system, and a permit has been obtained to discharge into that system; or

2. ODEQ has written, in response to an application, that no National Pollutant Discharge Elimination System (NPDES) permit is needed.

ODEQ has established water quality goals and regulations for 19 different water basins within Oregon. Water quality permit conditions are considered on a case-by-case basis. The size of the receiving stream and activity (see Table 11 ) are considered.

Approximate Time to Obtain Permit

A permit can usually be issued within 60 to 120 days of receipt of a completed application.

\section{Table 11}

NPDES Permit Application Forms

(OAR 340-45-030)

\section{Permit Category}

Any industrial, commercial, manufacturing, or mining activity
a. In quantities exceeding 50,000 gallons on any day of the year

b. In quantities of 50,000 gallons or less but which discharges a toxic pollutant
Application Form

Standard Form C [EPA Form 7550-23A (7-73)] 


\section{Permit or Regulation: Water Pollution Control Facility (WPCF)}

Statutory Authority: ORS Chapter 468; OAR 340, Division 45

Agency: Oregon Department of Environmental Quality (ODEQ)

This permit is for facilities that treat effluents by evaporative ponds or land application. It applies to construction or operation of a wastewater disposal system that does not discharge to navigable waters. Refer to the NPDES Permit.

WPCF permits ensure adequate water treatment in pollution control facilities.

Oregon Department of Environmental Quality (ODEQ) must approve plans before construction can begin. Requirements are set on a case-by-case basis.

\section{Approximate Time to Obtain a Permit}

A permit can usually be issued within 90 days after receiving a complete application.

\section{Permit or Regulation: Water Rights Permit}

Statutory Authority: ORS Chapter 537

Agency: Oregon Water Resources Department (OWRD)

The Oregon Water Resources Department (OWRD) regulates the use of state surface waters from rivers and streams, and groundwater from wells or aquifers.

Any project that will use any surface water (lakes, streams, rivers, waters stored in reservoirs, or other surface sources) or more than 5,000 gallons per day of groundwater must apply for a Water Rights Permit.

Oregon law says that all Oregon waters from almost all sources belong to the public. This permit grants a right to use the public's water for beneficial purposes.

The following dates are set by law:

Construction must begin within 1 calendar year after the permit is granted. (Construction may mean purchase of equipment.) No extension of time is allowed during this first year. Each permit is issued for only 1 year.

The developer has until October 1 of the next year to complete construction, and until October 1 of the year following to begin use. These latter two dates can be extended if satisfactory progress is being made. The developer should request a time extension from OWRD if necessary.

After water usage begins, the Watermaster's staff will inspect the facility. Water must be used for its intended purpose. The developer will not be allowed to use more water than the permit grants. If less water is being used, the permit will be modified. 
Special standards apply to Wild and Scenic Rivers.

\section{Approximate Time to Obtain Permit}

A 30-day legally-required waiting period begins when application is received. OWRD distributes a list of applications each week. Protests may be filed during this period.

OWRD grants the permit within 60 days after application. If no water is available, the application and fee are retumed.

\section{Land Use}

\section{Oregon's Land Use Planning Process}

The Land Conservation and Development Commission (LCDC) supervises planning in Oregon through its staff, the Land Conservation and Development Department. LCDC adopted 18 statewide planning goals from 1974 to 1976 (Table 12). Local governments adopt a comprehensive plan and state how planning, zoning, and development will be consistent with LCDC goals. The land use approval process is shown in Figure 18. Local plans are approved by LCDC. All cities and counties have LCDC-approved comprehensive plans.

\section{Table 12}

\section{Titles of LCDC Statewide Planning Goals}

1. Citizen Involvement

2. Land Use Planning

3. Agricultural Lands

4. Forest Lands

5. Open Spaces, Scenic and Historic Areas, and Natural Resources

6. Air, Water, and Land Resources Quality

7. Areas Subject to Natural Disasters and Hazards

8. Recreational Needs

9. Economy of the State

10. Housing

11. Public Facilities and Services

12. Transportation

13. Energy Conservation

14. Urbanization

15. Willamette River Greenway

16. Coastal Shorelands

17. Beaches and Dunes

18. Ocean Resources

For a complete description, request

"Statewide Planning Goals and Guidelines" from LCDC. 


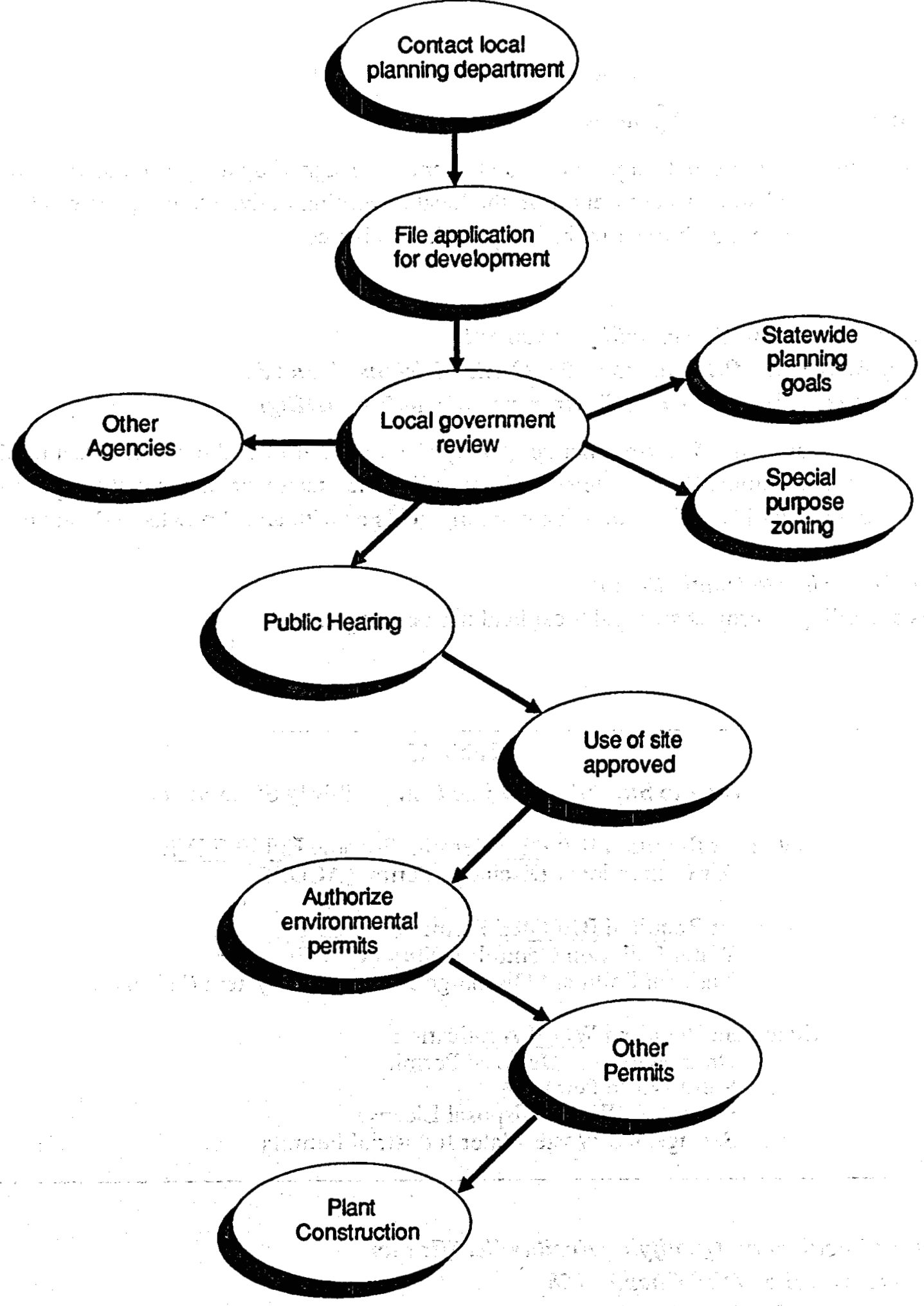

Figure 18: Local Government Land Use Approval Land Use Planning and Permit Process 
Coordination with Other Agencies

ODEQ requires a Land Use Compatibility Statement to be signed by a representative from local government. EFSC appoints advisers from the local governing body. Other agencies also require local government authorization before permits are issued.

\section{Statement: Land Use Compatibility Statement}

Statutory Authority: ORS Chapter 197; OAR, Divisions 30 and 31

Agency: Oregon Department of Environmental Quality (ODEQ)

An Oregon Department of Environmental Quality (ODEQ) permit will not take effect until you have a Land Use Compatibility Statement (Table 13). The Statement shows that the proposed project complies with LCDC's statewide planning goals or with an acknowledged land use plan.

\section{Approximate Time to Obtain Permit}

Varies according to project size and local land use permit process.

\section{Table 13}

When to Submit Land Use Compatibility Statements

Statement Required BEFORE Permits Become EFFECTIVE

Air Contaminant Discharge Permit (ACDP)

Statement Required BEFORE Permit is ISSUED

Water Pollution Control Facility (WPCF)

National Pollutant Discharge Elimination System (NPDES)

Statement Required WTTH Application

On-site Sewage Disposal Permits

Solid Waste Permits

Hazardous Waste Disposal License

Sewage and Waste Water Industrial Permits

\section{Permit or Regulation: Qualifying Facility Certification \\ Statutory Authority: ORS Chapter 758 \\ Agency: Oregon Public Utility Commission (OPUC)}

This applies to any cogeneration and small power production facility that, by definition, produces energy primarily by the use of biomass, waste, solar energy, wind power, water power, or geothermal energy.

Procedures for obtaining certification are the same as the FERC QF regulation. 
Approximate Time for Obtaining Certification

It will take about 90 days to obtain the certification.

\section{Safety/Health}

State law requires that construction plans be reviewed for compliance with fire, life, and safety provisions of the Uniform Building Code (UBC) and Uniform Mechanical Code (UMC). The Building Codes Agency process for such review is shown in Figure 19.

Further information regarding fire, life, and safety reviews may be found in ORS Chapters 447, 453, 454, and 476. All potential developers should discuss the codes with the Building Codes Agency.

\section{Permit or Regulation: Boiler or Pressure Vessel}

Statutory Authority: ORS Chapter 480; OAR 814, Division 25

Agency: Oregon Building Code Agency ()BCA)

This permit applies to any boiler or pressure vessel to be installed, altered, or repaired in the state of Oregon.

The law is intended to protect the safety of the people of Oregon from the hazard of fires and explosions caused by boilers and pressure vessels; to assure that only qualified persons do welding on boilers and pressure vessels; and to assure that vessels are properly manufactured, installed, repaired, operated, and maintained.

The law adopts the safety standards of the "Boiler and Pressure Vessel Code" and the "Code for Pressure Piping" of the American Society of Mechanical Engineers (ASME).

A "boiler" is a closed vessel or vessels intended for the heating or vaporizing of liquids to be used externally to such vessel or vessels by the application of heat from combustible fuels, electricity, or nuclear energy.

A boiler's "related appurtenances" include (but are not limited to) pressure piping directly connected and related to the safe operation of a boiler, and pressure piping beyond the second valve from the boiler.

"Pressure vessel" means containers for the containment of pressure, either internal or extemal. This pressure may be obtained from an external source or by the application of heat from a direct or indirect source, or any combination thereof.

Approximate Time to Obtain Permit

One week after submitting application, fees, and inspection. 
Application

forms from local

building department

and

BCA Boiler Section

Local Building

Department:

Struct/Mech

Electrical

Plumbing

Fire, life,

safety reviews

File

Applications

Permits Issued:

Construction Begins

Inspections

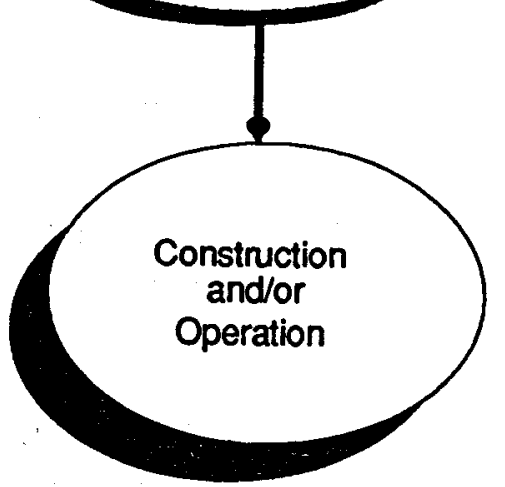

Figure 19: Building Codes Agency

Building Permit Process 
Permit or Regulation: Solid Waste

Statutory Authority: ORS Chapter 459; OAR 340, Division 61

Agency: Oregon Department of Environmental Quality (ODEQ)

This permit applies to land and facilities used for disposal of solid waste. Disposal sites include energy recovery facilities, incinerators, solid waste storage, handling, and transfer sites.

Disposal sites must obtain solid waste permits before they are established, operated, substantially altered, expanded, or improved. The ODEQ can set requirements for reporting, monitoring, entry, and inspection.

Applicant must submit two copies of the complete permit application. Written recommendations by the local solid waste management agency, a Land Use Compatibility Statement, and all information requested should be included. ODEQ may also require the following:

1. detailed plans and specifications, prepared and stamped by a professional engineer licensed in Oregon

2. a map of existing conditions, showing land use and zoning near the site

3. a description of proposed processing and disposal methods

4. a proposal for protection of the air, water, and land surrounding the disposal site

The disposal site must agree with local solid waste management plans.

Applicant should consult with ODEQ to determine whether a solid waste permit will be required.

\section{Approximate Time to Obtain Permit}

It will take approximately 60 days to obtain the permit.

Permit or Regulation: Hazardous Waste (EPA Generator ID Number)

Statutory Authority: ORS Chapter 459, 466; OAR 340, Division 102

Agency: Oregon Department of Environmental Quality (ODEQ)

This permit applies to any operation that generates useless, unwanted, or discarded manufacturing residue that is toxic, corrosive, ignitable, or reactive and developer does not intent to store the waste on-site.

Developer must apply for an EPA Generator Identification Number through the Solid and Hazardous Waste Division of ODEQ.

\section{Approximate Time to Obtain Permit}

Permit should be granted 5 to 7 days after receipt of the complete notification form. 


\section{Other Permits, Licenses, or Agency Review}

Permit or Regulation: Noise Control for Industry and Commerce

Statutory Authority: ORS Chapter 467; OAR 340, Division 35

Agency: Local Planning Agencies

Local agencies control noise through standards, review, and mitigation actions (see Tables 14, 15, and 16). There is no noise permit. A compliance schedule for certain high noise sources may be required, with intended actions listed.

\section{Table 14}

New Industrial and Commercial Noise Source Standards (OAR 340-35-035)

Allowable Statistical Noise Levels in Any One Hour
7 a.m. - 10 p.m.
10 p.m. -7 a.m.
L50 - 55 dBA
$L_{10}-60 \mathrm{dBA}$
L 50 - 55 dBA
$\mathbf{L}_{1}-75 \mathrm{dBA}$
L 10 - $55 \mathrm{dBA}$
$\mathbf{L}_{1}-60 \mathrm{dBA}$

\section{Table 15}

Industrial and Commercial Noise Source Standards

for Quiet Areas

(OAR 340-35-035)

Allowable Statistical Noise Levels in Any One Hour

7 a.m. - 10 p.m.

10 p.m. - 7 a.m.
L50 - 50 dBA
$L_{10}-55 \mathrm{dBA}$
$\mathrm{L}_{1}$ - $50 \mathrm{dBA}$
L50 - 45 dBA
$\mathrm{L}_{10}-50 \mathrm{dBA}$
$L_{1}-55 d B A$ 
Table 16

\section{Median Octave Band Standards for Industrial and Commercial Noise Sources}

(OAR 340-035)

Allowable Octave Band Sound Pressure Levels

Octave Band Center

Frequency

$\mathrm{Hz}$

7 a.m. -10 p.m.

10 p.m. -7 a.m.

31.5

68

65

61

125

250

500

1,000

2,000

4,000

8,000

55

52

49

46

43

40

65

62

56

50

46

43

40

37

34

If there is reason to believe that anyone may object to the noise levels to be generated by a new facility, an optional pre-construction review by the local planning agency should be requested. The developer should provide details of the type of equipment to be used, its location, and barriers to noise transmission on the site.

Sources exempt from noise regulations include:

- tire or road vehicle noise if the vehicles meet standards

- construction site activity

- capital equipment construction or maintenance

- agricultural activity

- tree harvesting

- other exceptions authorized by ODEQ

\section{A-95 Review}

When a project receives financing from federal agencies, the local planning department coordinates an A-95 review. Federal and state agencies like the Historic Preservation Office, Fish and Wildlife, Department of Energy, and others will be asked to comment. A-95 review will extend time for land use approval. 


\section{Local Permitting and Licensing Requirements}

\section{Determining Which Permits are Required}

To enable a developer to determine what local permits are necessary for a particular site, and for guidance in obtaining local permits, the following guidelines are provided:

- Determine with certainty within what local jurisdiction the project site lies. Assumptions about jurisdiction are often inaccurate. Even if a site is within the county, it is possible it may be within a city's Area of Impact, which would give the city certain jurisdiction over the project.

- Contact agency staff early to obtain information about permits and to discuss plans. Go into their office in person to make personal contact and to show commitment to expediting the permitting process.

- Determine what permits will be required for the proposed project; what information should be provided; the process that will be followed; and time frames, including submittal dates, hearing dates, and the time within which a decision can be expected.

- Get copies of the applicable regulations so you can personally review them and the evaluation criteria. Ask questions if the written regulations vary from information the staff has provided.

- In the case of more discretionary permits, ask the staff about the likelihood of approval; also what might help to speed up the process and decision.

- Submit a complete application. Incomplete applications will result in processing delays.

- Attend all meetings where the application will be discussed. If there is no one to respond to questions, delays may occur or the permit may be denied.

\section{Land Use}

\section{Permit or Regulation: Land Use or Zoning}

Statutory Authority: ORS Chapter 454

Agency: City or County Planning Department

Any commercial, agricultural, or industrial project will be subject to land use and/or zoning regulations.

The local planning department must approve the use of a site for energy conversion before plans can be submitted for building permits. 
Some local governments require an architectural design review after the use of the site has been approved.

If the energy conversion process does not fit the site zoning class, a conditional use permit (CUP) or an amendment to the General Plan may be necessary.

An application for use of a site is considered during a public hearing where it is denied, approved, approved with conditions, or continued. A continuance refers the application back to planning staff for further review prior to another hearing. At the end of the process, the applicant will receive a letter that will approve or deny the intended use of the site.

Approval is complex. Projects are reviewed to assure protection of public health, safety, and general welfare; to comply with statewide planning goals; and to comply with a city or county comprehensive plan. Local government must: coordinate with other state and federal agencies; consider special purpose zoning like historic preservation sites; and consider water quality, soils suitability, fish and wildlife, noise, and public roads.

\section{Approximate Time to Obtain Permit}

It takes approximately 60 to 120 days to approve a site. Sometimes approval can take over a year if the project is extremely complex or controversial.

\section{Construction}

\section{Permit or Regulation: Building (Building, Electrical, Mechanical, Plumbing) \\ Statutory Authority: ORS Chapter 479}

Agency: City or County Building Department

This permit applies to all geothermal energy projects. Building permits are issued by the local building department. The permits ensure that construction plans meet the state adopted Uniform Building Code (UBC) or the Uniform Mechanical Code (UMC). Cities and counties differ in the amount of responsibility they assume for plan review and inspection. The state Building Codes Agency assists some areas through its field offices.

Building permits are not issued until the use of the site is approved by the planning department. Buildings more than 20 feet in height or 4,000 sq. $\mathrm{ft}$. in size, and energy plants and processes that require engineering judgment or affect public health and safety must be designed by a licensed architect or engineer.

Electrical plans must be stamped by a registered electrical engineer.

\section{Approximate Time to Obtain Permit}

Most permits are granted within 3 weeks of application. Complex plans may require a longer review period. 


\section{Permitting \\ Agency}

MAJOR FACILITY SITING/ENVIRONMENTAL IMPACT

WA Energy Facility Site Evaluation

State Environmental Policy Act

EFSEC $>250 \mathrm{MW}$

AIR QUALITY

Burning Permit

New Source Constr. Approval

Ecology

WDNR

APCA

Ecology or

Local Air Auth.

\section{WATER QUALITY/WATER USE}

Water Right

Water Quality Certification

Ecology

Ecology

Short-term Modification of Water Quality Criteria Ecology

Drilling Bond

Permit to Commence Drilling, Redrilling, or

Deepening

Flood Control Zone Permit

Underground Injection Control Permit

National Pollutant Discharge Elimination Sys.

State Waste Discharge Permit

Hydraulic Project Approval

Public Water Supply Approval

Surface Water Drainage Plan Approvals

Wastewater Facilities Plan Approval

\section{LAND USE}

Geothermal Leasing

Archaeological Approval

Section 106 Review

Surface Mining Permit

Dumping Permit

Right-of-Way or Road Use

Application to Purchase Valuable Material

Permit to Temporarily Remove or Destroy

Survey Monument

Special Motor Vehicle Use

Shoreline Substantial Develop. Permit

Zoning Conditional Use Permit

Utility Permit

Permit to Operate Overweight Vehicles

on City or County Roads

Forest Practices Approval

\section{CONSTRUCTION}

\section{Burning}

Commercial Building Permit

Plumbing Permit

Grading Permit

Sewage Holding Tank Variance

Wastewater Facilities Plan Approval

SAFETYAEALTH

Dam Safety Construction/Reservoir

Operation Permits

Solid Waste Disposal Permit

Hazardous Waste Disposal Permit

Boiler License

Public Water Supply Approval

OTHER

Cogeneration and Small Power

Production Facilities Certification

Agencles

APCA Air Pollution Control Authority

WDNR Washington Department of Natural Resources

WDOT Washington Department of Transportation

WDSHS Washington Department of Social and Health Services

Ecology Washington Department of Ecology

EFSEC Energy Facility Site Evaluation Council

FERC Federal Energy Regulatory Commission

WDF Washington Department of Fisheries

WDW Washington Department of Wildlife

WOAHP Washington Office of Archaeological and Historic Preservation

WUTC Washington Utilities and Transportation Commission

WDNR

WDNR

Ecology

Ecology

Ecology

Ecology

WDF/WDW

County

Ecology

WDNR

WOAHP

WDNR

WDNR

WDNR

WDNR

WDOT

County

City/County WDNR

WDNR

County

County

County

County

Ecology

Ecology

Ecology

Ecology

$?$

\section{WUTC/FERC}

Thermal Thermal Trans-

Resources Resources mission $<250>250$ Lines

County/Ecology





Cogen-

Wind Ceo-

thermal

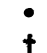

$t$
$t$
$t$

+
+
$\vdots$
-

Key

$t=$ Permit required

- $\quad=$ Permit may be required

$x=$ Included in Energy Facility Site Evaluation Council Review

$*$ Site specific

$t=$ Transmission lines built to integrate thermal plants are covered by EFSEC 


\section{Chapter 5 \\ The Washington State Process}

\section{Legal Definition and Determination of Ownership}

\section{Definition}

The Revised Code of Washington (RCW) defines "geothermal resource" differently than the federal government. The definition reads as follows:

'Geothermal resource' means only that natural heat energy of the earth from which it is technologically practical to produce electricity commercially and the medium by which such heat energy is extracted from the earth, including liquids or gases, as well as any minerals contained in any natural or injected fluids, brines, and associated gas, but excluding oil, hydrocarbon gas, and other hydrocarbon substances (Chapter 79.76, RCW). (Emphasis added.)

The principal difference in the Washington definition is that it restricts geothermal resources to those "from which it is technologically practical to produce electricity commercially." Washington State defined geothermal resources in this way to clearly divide responsibilities for purposes of regulation. This mechanism gave the Washington Department of Natural Resources, which regulates oil and gas drilling, the responsibility to regulate high temperature and pressure resources, and gave the Washington Department of Ecology, which regulates groundwater, the responsibility to regulate low temperature and pressure geothermal resources.

In Washington, the legislature declared that "notwithstanding any other provision of law, geothermal resources are found and hereby determined to be sui generis (unique unto itself), being neither a mineral resource nor a water resource" (Bloomquist, et al., 1980).

In Washington, as long as the resource is used solely for electrical generation, a water right is not required. However, if the resource is cascaded for other uses, e.g., space or process heating, a water right must also be obtained. Geothermal resources with temperatures below those required for commercial electricity production are considered groundwater resources in Washington, and are regulated as such by the Washington Department of Ecology.

Historical uses of groundwater included domestic, agricultural, and industrial purposes, but not energy extraction. Because of this, conflicts between existing uses and the needs of the geothermal energy industry have become a serious consideration, one that can severely limit geothermal development, especially in critical groundwater areas. 


\section{Ownership}

Washington has declared geothermal resources to be the property of the surface owner (Chapter 71.76, RCW). Because of the way in which the state has defined geothermal resources, however, it is presently unclear what is truly included in this assignment and what remains available for appropriation as groundwater. The state claims ownership of all groundwater underlying state and school lands. In order to gain access to low temperature geothermal resources below these lands, a commercial lease must be obtained. Assigning geothermal resources to the surface owner in Washington will likely result in court challenges by those who have maintained interests in mineral estates when estates have been severed.

\section{Obtaining Access to Geothermal Resources}

\section{State Lands}

The Washington Department of Natural Resources (WDNR) manages the majority of state lands, with the only exceptions being lands managed by the Washington Department of Wildlife, Parks and Recreation Commission lands, and small holdings by other state agencies. Access to nonWDNR lands for the purpose of geothermal exploration may be allowed once a permit is obtained from the local office of the agency managing the lands. The exploration activities permitted includes such things as geologic mapping and spring sampling.

The WDNR is responsible for issuing leases on state trust lands for the purpose of geothermal exploration and development whether it be for electrical generation or direct utilization. A Plan of Operation is required by WDNR for such exploration and development activities. Leasing rules and regulations were adopted in early 1992, and are available from the Washington Department of Natural Resources, Division of Lands.

\section{Indian Lands}

In the $1850 \mathrm{~s}$, a series of treaties were negotiated between the United States and a number of the Indian tribes in the Washington Territory by Isaac Stevens.

In exchange for giving the United States title to most of their land, the Indians retained reservations for homelands as well as a right to continue hunting and fishing at their usual and accustomed places, both on and off the reservation.

All of the so called Stevens treaties were negotiated, executed, and ratified by Congress well before Washington became a state. In the ensuing decades, the treaties were interpreted by the federal courts. The court rulings followed earlier Supreme Court rulings concerning Indian treaties and established several basic principals. Most fundamentally, the rights retained by the tribes are reserved rights, that is, they are rights retained by the tribes at the time of treatymaking, and not given to them by the United States. 
Each tribe that signed a treaty has a property right to the use of the resources in question. As a property right retained from before statehood, treaty rights are in the nature of easements on other real property interests.

Treaty rights have also been found by the federal courts to include an environmental right. For example, court decisions have forbidden actions that would inundate usual and accustomed fishing sites, dewater fish habitat, or degrade water quality to the detriment of the fishery.

Indian water rights stem from a 1908 Supreme Court decision which stated that when land was set aside for reservations, it was implied that water was also reserved for tribal uses. It does not matter if the water has been put to use or not, it is still reserved for use on the Indian reservation.

Though altered somewhat by subsequent court cases, the Winters Doctrine, as this decision is known, remains the basis for Indian water rights. The Winters Doctrine usually refers to direct water use, rather than the protection of instream flows for fish habitat. There are many Winters Doctrine-based water claim cases currently in state and federal courts. The outcome of these cases could have a profound impact on current Western United States water use.

In 1984 the EPA announced that it would "work directly with Indian tribal governments on a one-to-one basis." This policy recognizes tribal governments as sovereign entities with primary responsibility for reservation environmental issues, such as air and water quality and related matters. This means that the tribes can contract directly with the EPA to administer the Clean Water Act, the Clean Air Act, and similar environmental programs on their reservations (Brown, 1991).

Individual Indian lands (allotments) held in trust by the U.S. or tribal land held in trust by the U.S. can be permitted or leased for mineral development under authority of a March 3, 1909, act, Leases of Allotted Lands for Mining Purposes, or a May 11, 1938, act, Leases of Unalloted Lands for Mining Purposes, Duration of Leases, and the 1982 Indian Mineral Development Act. These acts are regulated by 25 CFR 211.212, and 216, and by 43 CFR 3100 through 3590 . The Bureau of Indian Affairs (BIA) is responsible for exploration permits, lease approval, and administration. The BIA is responsible for operational supervision of prospecting and development.

Access to Indian lands for non-disturbing surface exploration requires written agreement between operators and Indian land owners. Surface disturbing activities, including prospecting and development, require approval by BIA and the Bureau of Land Management (BLM). The point of first contact should be between the prospective operator and tribal governments.

Finally, and perhaps most significantly, the tribes as governmental entities have a right to manage their resources. This means that the tribes undertake all activities necessary to adequately manage the resource, including protecting the environment necessary to sustain the resource (see The Federal Process, pages 9-65, for additional information on Indian lands). 


\section{Tribal Requirements}

Development on tribal reservation land may be subject to tribal laws not detailed in this guide. The appropriate tribal planning office should be contacted prior to conducting activities on tribal land. For a list of tribal contacts, see Appendix 1F.

When a project is on non-tribal lands but may affect treaty-reserved resources or areas of tribal significance, agencies have an obligation and responsibility to consult with tribal govemments during the project review process. Mitigation may be required to protect treaty rights.

Prevention of damage to Indian graves or artifacts is required. Unlawful removal or mutilation of artifacts or burial sites is punishable as a felony under Washington State law.

\section{State Laws Regarding Indian Lands:}

State Archaeological Sites and Resources Act, Chapter 27.53, RCW

Indian Graves Law, Chapter 27.44, RCW

\section{Private Lands}

Developable resources are often found on private lands. Accordingly, one of the first activities is to gain access. Access to private land can be obtained by sale, lease, permit, option, or any other mutual agreement with the owner of the surface property and geothermal estate.

Landowners may permit access prior to a lease or purchase option. This allows the developer to conduct agreed upon preliminary exploration activities. Such activities could include geological and geophysical investigations that are non surface disturbing and the drilling of temperature gradient holes. (A state well drilling permit is required for exploratory drilling on private land.) Additional federal, state, and/or local permits are required for continued development. These are covered in subsequent sections.

Sales

A landowner who sells property to a developer transfers all interest and control in the property and its geothermal resources for a fixed price. The landowner does not incur the risks of development. The developer pays the market value of the property, taking into consideration any value added by the resource. A landowner who is paid in full need not be concerned with the development. However, a landowner who is to be paid over time from the project's geothermal resource or electricity sales revenues may retain some control over the property and its development as security for future payment. A landowner who wants to use the property for farming or grazing can lease back the property sold to the developer.

\section{Lease}

Instead of selling the property, the landowner may rent or lease it to the developer for a fixed term. In most instances, access to private land is obtained through a geothermal lease. Leasing 
terms generally include length of lease, royalty payments, lease fees, and stipulations governing exploration and development activities. Terms are often based on state and federal oil, gas, and geothermal leasing guidelines. A lease or rental agreement allows the landowner to retain some control over the development and use of the land.

\section{Option to Purchase or Lease}

Instead of an immediate purchase or lease, the developer can buy an option by paying the landowner a sum, usually a small percentage of the property value. The option holds the property off the market while the developer determines whether to make a final purchase or lease. The terms of the final purchase or lease are negotiated and set forth in the option agreement.

Two agreements are needed for the developer to obtain the right to purchase or lease the property later and the right to complete an exploration program: an option's agreement, and a short-term lease or license agreement. Either a license or lease allows the developer to use the land during the option period.

At the end of the option period, the developer must decide whether to purchase or lease the property at the price and terms in the option agreement, or to give up all interest in the land. An option assures that the developer can buy or lease the property for a set price in the future. For instance, the developer can buy an option to purchase or lease the property at a low price in 5 years. Tests may show that the property has valuable resources. The developer can exercise the option at the low price despite the increased value of the land. However, if tests show that the geothermal resource is less valuable than thought, the developer is not bound to buy or lease the property.

The landowner cannot accept a better offer during the option period. The option price should adequately compensate the landowner for keeping the property off the market. The value of an option right depends on the length of the option period and the strength of the resource. If more than one developer wants to buy an option, the competition will increase the value of an option.

\section{Right of First Refusal}

A right of first refusal is often confused with an option to purchase. Unlike an option, a right of first refusal does not set a price for the property. A developer who buys a right of first refusal merely obtains a right to match any offer to buy the property. Thus, a landowner who receives an acceptable offer from a third party would be required to communicate the offer to the developer. The developer then has the right to match the offer and obtain the property or allow the property to be purchased by the offeror.

A landowner may specify that a right of first refusal does not apply to offers to purchase made by specific parties such as family members. This allows the landowner to transfer ownership within a family while granting a developer a right of first refusal on offers made by others. 
If the area of interest is already under lease for other purposes such as farming or grazing, the developer must secure permission through easement from the lessee for surface access rights.

\section{Easement}

A developer can negotiate an easement for access with adjoining landowners. An easement is a right to make limited use of real property in airspace. A landowner can sell an easement granting the developer the right to use the space across and above the property. This grants a positive right. An adjoining landowner may also agree to restrict vegetation, structures, or other objects that would impair or obstruct transmission lines. This is called negative easement.

An easement may be perpetual or for a specified time. Once granted, a perpetual easement may not be terminated except as stated in the easement, by court decree based upon abandonment or changed conditions, or by agreement of the parties.

To be effective, an easement must be in writing and be recorded in county property records. A landowner who has granted an easement can sell the property but the new owner will be bound by the terms of the easement. Similarly, if the developer sells the property benefited by the easement, the new owner will be entitled to the same rights as the developer. This is what the law means when it says that the easement is appurtenant to the land and follows with the real property benefited and burdened by the easement.

Easements may also be granted for uses other than access to energy resources. The uses of the easement are stated in the easement. For instance, an owner of adjoining property may grant a developer an easement to cross the property to install and repair equipment or the right to erect and maintain transmission lines. Easements from several parties may be necessary to install transmission lines.

\section{Covenant}

When property is sold, restrictions may be placed in a purchaser's deed prohibiting certain uses of the land. A developer who acquires only part of a larger parcel can ask the landowner to agree that when other parcels are sold, the deeds will contain restrictive covenants prohibiting new owners from obstructing the developer's access.

Restrictive covenants that preserve access must be in writing and should be recorded. Recorded covenants bind successive purchasers of land burdened or benefited by covenants.

\section{Permit or License}

The landowner may grant the developer a permit or license to use the land or airspace for a specified time or purpose. This right is generally revocable at the landowner's will and may not be transferred or assigned. The developer who acquires a personal license or permit does not acquire a legal interest in land that can be recorded or mortgaged. 


\title{
Contract Provisions
}

Both the developer seeking access rights and the landowner interested in leasing resources would be wise to invest in competent legal advice. Consultation with a qualified accountant regarding royalty payments and applicable tax laws is also advised. Contracts developed for a specific purpose, such as oil and gas leasing, may not be appropriate for geothermal development. The parties should design a contract that meets their specific needs and time requirements of the project.

\section{Washington State Agency Responsibilities}

\author{
Agency: Washington Department of Natural Resources (WDNR) \\ Statutory Authority: RCW 43.30.030
}

RCW Chapter 79.01.096 gives the Washington Department of Natural Resources (WDNR) the authority to lease state trust land for the purpose of geothermal exploration and power plant construction. The Division of Lands was instructed to adopt rules and regulations for leasing state lands for geothermal exploration and development by December 1991.

Rules and regulations governing geothermal drilling have been adopted by WDNR. WDNR is also responsible for processing and issuing geothermal well drilling permits. Chapter 332-17 of the Washington Administrative Code (WAC) discusses the requirements for drilling geothermal wells on both state and private lands. As part of the requirements under the geothermal drilling rules and regulations, an operator or owner proposing to drill must first obtain a drilling bond.

WDNR has also established a policy concerning awarding right-of-way over state trust lands for the purpose of constructing roads or transmission interties. RCW 79.01.384 and .388 allow the state to grant rights-of-way to municipalities, private corporations, associations, or individuals for the purpose of constructing ditches, flumes, pipelines, or transmission lines in order to generate or transmit electricity. The applicant is required to complete a survey of the involved land and append plats to an Application for Right-of-Way or Road Use Permit Over Lands. WDNR may charge a one-time payment for permanent development rights that is based upon the fair market value of the land involved, or may require a base annual rental plus a percentage of gross income.

\section{Agency: Washington Department of Ecology (Ecology) Statutory Authority: RCW 43.21A.040}

As the state environmental management and protection agency, the Washington Department of Ecology (Ecology) is responsible for ensuring that the water and related land resources of the state are protected and fully utilized for the greatest benefit to the people of the state. Ecology administers several state permits designed to ensure environmentally sound geothermal project development. These permits must be obtained prior to beginning construction of a project 
in the state of Washington. Prior to approving water rights for projects, Ecology ensures that the affected stream or reach is provided with minimum instream flows necessary to preserve wildlife, fish, scenic, recreation, aesthetic, and other environmental values, including water quality. Ecology processes water right permits that are required before the construction of any water well. A water right, if needed, should be applied for well in advance of construction. Ecology will inspect the site, require publication of a public notice, and attempt to resolve any protests filed. A permit allowing construction of the project may be issued if water is available, no existing water rights are affected, and the project would not be detrimental to the public welfare. A final certificate of water right is issued after the project is completed and water is put to use.

Ecology regulates the drilling of all water wells within the state regardless of land ownership. In Washington, regulatory responsibilities for water wells, i.e., all wells for hydrothermal resources not capable of being utilized for commercial electrical generation, lies with Ecology. The construction of a water well must conform to RCW 18.104 to ensure the protection of public resource aquifers. Ecology publishes a handy booklet related to well construction that contains the following information:

- Minimum Standards for Construction Maintenance of wells, chapter 173-160 WAC

- Rules and Regulations Goveming the Regulation and Licensing of well contractors and operators, chapter 173-162 WAC

- Water Well Construction Act (1971), chapter 18.10Y RCW

Ecology also maintains a mailing list of those interested in groundwater issues. To be put on the mailing list or for more information write to the Water Quality Program, Washington Department of Ecology (address in Appendix 1E).

The National Pollutant Discharge Elimination System (NPDES) or State Waste Discharge Permit, Water Quality Certification and/or Short-Term Modification of Water Quality Standards, and the Wastewater Facilities Plan Approval ensure that the water quality will not be adversely affected by the project. According to Ecology, an NPDES permit is required whenever a discharge will be made into surface waters of the state. The State Waste Discharge permits are required for virtually all other discharges, e.g., onto land surfaces, into an existing waste treatment system, and by subsurface injection (Offord, 1990).

The State Environmental Policy Act requires that proposed development in the state of Washington be evaluated to identify the environmental impacts that will result before state and local permit decisions are made. To assist developers in obtaining information on state permits, Ecology has established the Environmental Permit Information Center (EPIC). Additional information pertaining to the EPIC will be covered in a subsequent section (see Environmental Coordination Procedure Act. chapter $90.62 \mathrm{RCW}$ ). 


\section{Agency: Washington Department of Fisheries (WDF) \\ Statutory Authority: Chapter 75.08 RCW}

Under state law, the Washington Department of Fisheries (WDF) is charged to preserve, protect, perpetuate, and manage the food fish (e.g., salmon, smelt, sturgeon) and shellfish in state and offshore waters (RCW 75.08.012). To ensure WDF can carry out its responsibilities, the law requires that:

- water diversion devices be equipped with a well-maintained fish guard (RCW 75.20.050)

- where practical, dams and other obstructions across or in a stream be equipped with a durable and efficient fishway (RCW 75.20.060)

- any person desiring to conduct work that will use, divert, obstruct, or change the natural flow or bed of any stream secure written approval from the department (Fisheries or Wildlife) having jurisdiction of the site

This might apply to geothermal generation projects that require surface water for cooling or as an additional source of water for injection. The WDF is actively involved in consulting and conducting feasibility studies to evaluate and mitigate impacts on fisheries resources.

\section{Agency: Washington Department of Wildlife (WDW) Statutory Authority: Chapter 77.04 RCW}

The Washington Department of Wildlife (WDW) is mandated by the legislature to ". . preserve, protect, and perpetuate wildlife. . ." of Washington (Title $77 \mathrm{RCW}$ ). These wildlife, which are property of the state, include wild animals, wild birds, and game fish. Policies set forth by the WDW state that, "The first management priority will be to establish and perpetuate the highest quality wildlife habitat."

WDW also has obligations under such federal laws as the Federal Power Act and Fish and Wildlife Coordination Act. These require developers to consult with state agencies to determine what conditions may be necessary for protection of fish and wildlife resources. The WDW commonly works together with other agencies, such as Department of Fisheries, National Marine Fisheries Service, U.S. Fish and Wildlife Service, and Indian tribes, to determine potential impacts and possible mitigation proposals.

Although each geothermal project is individually evaluated, some guiding principles are common. Replacement of losses in-kind and on-site is the objective of the Department's mitigation and compensation efforts. Although this cannot be achieved exactly, it may be approached in several ways.

WDW works with project sponsors to ensure in advance that adequate measures to protect fish and wildlife are included in initial plans. Specific provisions are usually assumed by the project sponsor and must be incorporated into the cost/benefit analysis of the planning process. 
WDW requires studies that will determine project-specific and cumulative impacts and identify mitigation and enhancement measures. On rivers where cumulative impacts are possible, delays may occur as studies are conducted. These studies are funded by project proponents, preferable under the direction and guidance of fish and wildlife agencies. WDW also advises project sponsors throughout the planning, development, and operational phases of the project.

\section{Agency: Washington State Energy Office (WSEO) Statutory Authority: RCW 43.21F.035}

It is the policy of the Washington State Energy Office (WSEO) to promote the development and use of a diverse array of energy resources. The use and development of renewable energy resources are particularly encouraged provided that such projects are consistent with the statutory environmental policies of the state. In order to assist in the construction of environmentally acceptable and cost-effective renewable resource projects, the WSEO has established a renewable resource section within the agency. Renewable resource specialists assist potential developers through the state and federal leasing, licensing, and permitting processes, as well as provide technical assistance in the areas of financing, design, and overall project development.

\section{Agency: Washington Office of Archaeology and Historical Preservation (WOAHP) Statutory Authority: RCW 27.34.210}

The Washington Office of Archaeology and Historical Preservation (WOAHP) is responsible for ensuring that a proposed development site is not listed in the National Register of Historic Places. If it is listed, OAHP will determine the number and extent of any resources and their scientific or cultural importance. Accordingly, plans and procedures will be outlined for impact mitigation.

\section{Agency: Energy Facility Site Evaluation Council (EFSEC) Statutory Authority: RCW 80.50.030}

Washington has given its energy facility siting authority limited powers over only state and private lands. For example, in Washington the Energy Facility Site Evaluation Council (EFSEC) maintains siting jurisdiction over all lands, private and state owned, but only when on-site improvements to an existing facility with capacity in excess of over $250 \mathrm{MW}$ or more will exceed $\$ 250,000$, or a proposed generating plant will have a capacity of $250 \mathrm{MW}$ or more (Bloomquist, et al., 1980). Thus, geothermal development would not be expected to fall under the jurisdiction of the EFSEC; it would be regulated by the Departments of Natural Resources and Ecology and possibly fall under local jurisdiction as well. The exemption of most geothermal developments in Washington from EFSEC regulations may, as some developers contend, simplify the siting process. However, EFSEC's ability to coordinate application processing through all state and local agencies could result in substantial savings in both time and money by helping shorten the 
lead time from exploration to plant construction and power on-line. Some consideration is being given to lowering the threshold for EFSEC review to $50 \mathrm{MW}$, putting Washington more in line with regulations in Oregon and Montana.

\section{Agency: Washington Utilities and Transportation Commission (WUTC) Statutory Authority: Title $80 \mathrm{RCW}$}

The general duties of the Washington Utilities and Transportation Commission are to regulate electric companies, gas companies, irrigation companies, telecommunications companies, and water companies. Rates, services, facilities, and practices of all persons engaged in the business of supplying any utility service or commodity to the public for compensation are subject to the rules and regulations of the WUTC.

Chapter 480-107 WAC Electric Companies-Purchases of electricity from qualifying facilities and independent Power Producers and Conservation Suppliers establishes rules for determining rates, terms, and conditions governing purchases by eclectic utilities concerning: electricity from qualifying facilities; the electrical savings associated with eligible conservation measures; electricity from independent power producers; and electric utilities. The rules are intended to provide an opportunity for conservation and generating resources to compete on a fair and reasonable basis to fulfill a utility's new resource needs. It is the commission's intent that bids under these rules shall include the costs of compliance by the project with environmental laws, rules, and regulations in effect at the time of the bid and those reasonably anticipated to be in effect during the term of the project.

The rules are consistent with the provisions of the Public Utility Regulatory Policies Act of 1978 (PURPA), Title II, sections 201 and 210, and regulations promulgated by the Federal Energy Regulatory Commission (FERC) in 18 C.F.R., Part 292.

The rules do not preclude electric utilities from constructing electric resources, operating conservation programs, purchasing power through negotiated purchase contracts, or otherwise taking action to satisfy their public service obligations.

The provisions of the chapter apply to any electric utility which has submitted to the commission a least-cost plan as provided in WAC 480-100-251.

A "least-cost plan" means a plan describing the mix of generating resources and improvementś in the efficient use of electricity that will meet current and future needs at the lowest cost to the utility and its ratepayers.

Each electric utility regulated by the commission has the responsibility to meet its load with a least-cost mix of generating resources and improvements in the efficient use of electricity. 


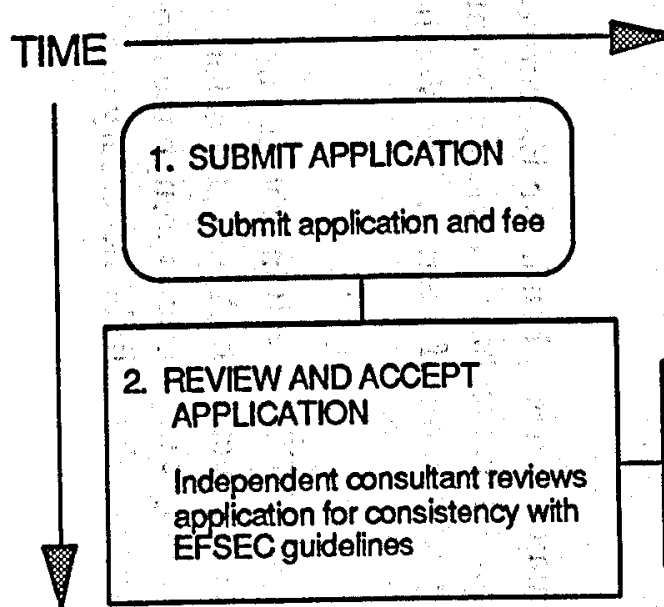

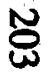



Figure 20: Application Process 


\title{
Washington State Permitting and Licensing Requirements
}

\section{Major Facility Siting/Environmental Impact}

\author{
Permit or Regulation: Energy Facility Site Evaluation \\ Statutory Authority: Chapter $80.50 \mathrm{RCW}$; Title 463 WAC
}

Agency: Energy Facility Site Evaluation Council (EFSEC)

The Energy Facility Site Evaluation Council (EFSEC) and the certification process (licensing) for siting, construction, and operation of major energy facilities is to ensure through available and reasonable methods, that the location and operation of major energy facilities will produce minimal adverse effect on the environment, ecology of the land and its wildlife, and the ecology of the state waters and their aquatic life.

EFSEC is a Washington State agency comprised of a chairman appointed by the Governor and representatives from 13 state agencies. EFSEC is augmented by representatives from particular cities, counties, or port districts potentially affected by a project. EFSEC was created to provide a one-stop licensing agency for major non-hydro energy projects.

EFSEC is the only state agency to which an application to construct and operate a major energy facility may be filed. After EFSEC reviews an application, it makes a recommendation to the Governor. The Governor is the final decision maker for approval or disapproval of the application.

For projects reviewed by EFSEC, approved by the Governor, and granted a license to construct and operate, EFSEC then regulates the construction and operation of the plant in accord with conditions of the license. EFSEC fulfills its regulatory function through contracts with state agencies having the expertise to monitor and evaluate each aspect of the project. EFSEC has the authority to fine the owner or stop construction or operation if licensing conditions are not met. EFSEC continues this oversight responsibility through site restoration after termination of the project.

To accomplish its work, EFSEC meets regularly to discuss major issues at hand. An Executive Committee provides administration and sets EFSEC agendas. Ad hoc technical review subcommittees may be formed for individual projects or review of special items of interest. The Washington State Energy Office provides staff to EFSEC.

It is strongly recommended that prospective applicants meet with EFSEC well in advance of submitting an application. The EFSEC process is very open but structured. Applications for major energy facilities must be complete and thorough before they can proceed through the process. Early meetings with EFSEC will help applicants understand what will be necessary and desirable for a specific project. 
The EFSEC certification process (see Figure 20, page 205) was designed to give the applicant and others an opportunity to express their proposal and concerns to EFSEC, and for EFSEC to address interests which have bearing on matters arising from the application.

In as much as EFSEC certification is required only if the proposed facility will exceed 250 MWe, geothermal facilities will not be subject to the certification process unless the $250 \mathrm{MWe}$ threshold is revised downward.

The certification process may start in one of two ways. First, an applicant may apply to EFSEC to begin the process or second, an applicant may want to have EFSEC conduct a Potential Site Study before applying for a Site Certification Agreement (SCA). Because of the costs involved in preparing a full application, a Potential Site Study offers the benefit of determining if there are any environmental, social, or regulatory "hurdles" that can't be overcome. This can result in great savings of time and expense.

\section{Permit or Regulation: State Environmental Policy Act (SEPA) \\ Statutory Authority: Chapter 197-11 WAC Agency: Washington Department of Ecology (Ecology)}

The Washington State Environmental Policy Act (chapter 43.21C RCW) requires state and local agencies to evaluate proposed projects for their environmental impact before issuing any permits or other approvals. Figure 21 highlights the key steps in the State Environmental Policy Act (SEPA) process and provides references to the applicable sections of the SEPA rules.

These rules are available in booklet format from any Washington Department of Ecology or Washington Department of Natural Resources office.

When a developer submits a permit application, the agency receiving the application determines whether or not the project is exempt from SEPA. If it is not, the agency then determines which agency requiring a permit is the "lead agency." The SEPA lead agency is responsible for complying with SEPA for a particular project. For any proposal involving a geothermal electrical generation project that is $250 \mathrm{MW}$ or greater, the lead agency is the Energy Facility Site Evaluation Council (RCW 80.50.020). For electrical generation projects under $250 \mathrm{MWe}$, the lead agency is the Washington Department of Natural Resources or the city or county in which the project is located. A public agency proposing a geothermal project is most likely to be the SEPA lead agency for that project.

When SEPA compliance is required for a project, the developer must complete an environmental checklist, unless the developer and the lead agency agree that an environmental impact statement (EIS) will be prepared. The lead agency gives the checklist to the developer, who may complete it alone or together with the lead agency. The completed checklist provides specific information 


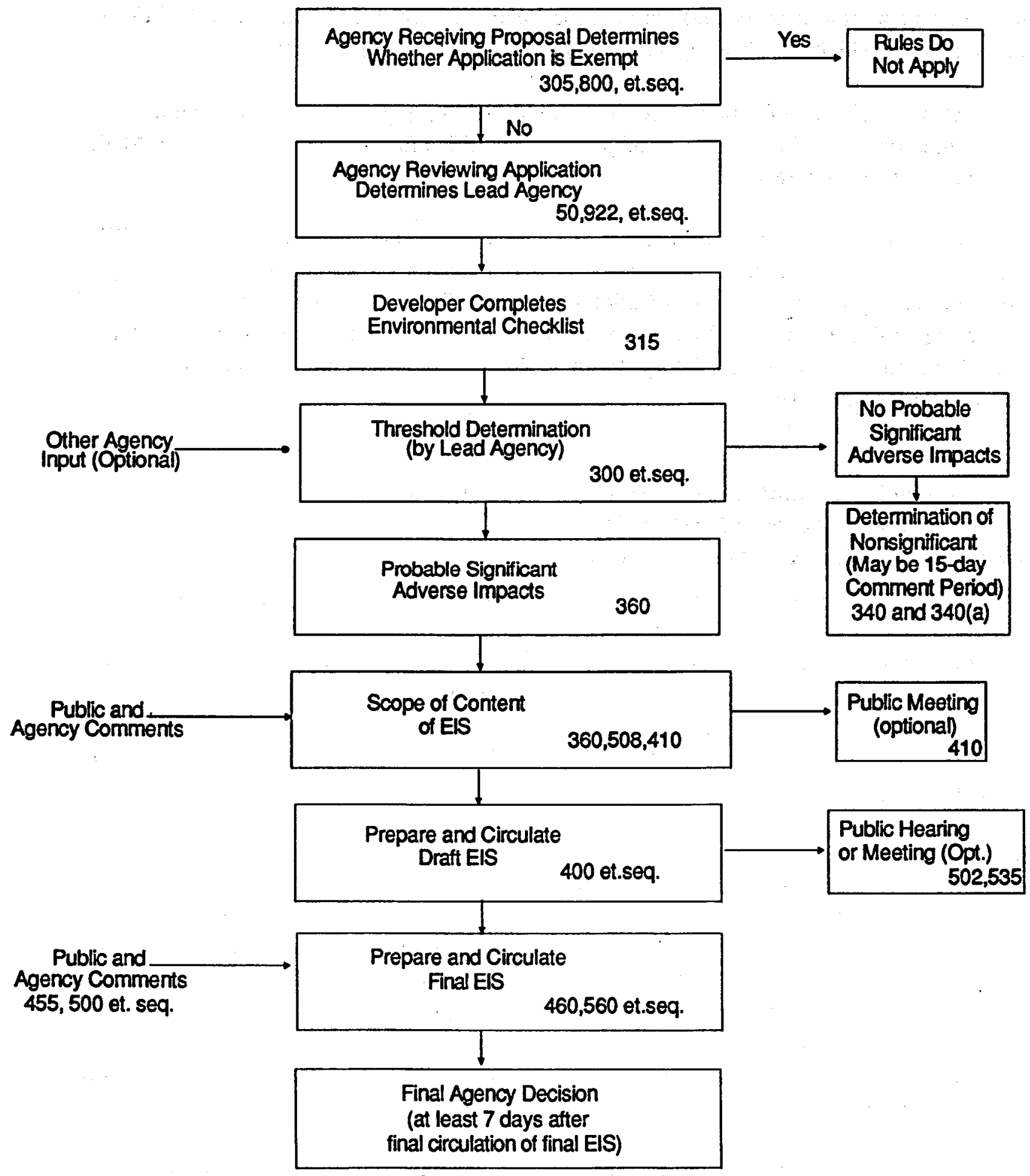

Figure 21: The SEPA Process 
about the project, helps the developer and the lead agency identify potential impacts from the project (to reduce or avoid these impacts, if possible), and helps the agency decide whether an EIS is required.

When the lead agency receives the completed environmental checklist, it makes the threshold determination to decide whether an EIS is needed. If the lead agency determines the project is unlikely to have a significant adverse impact on the environment, it issues a Determination of Nonsignificance (DNS) and sends it to all agencies with permits or approvals to issue. These include agencies whose services would be affected by the project, affected Indian tribes, and interested persons. The lead agency must also give public notice that the DNS has been issued; the method will vary among agencies. Any person or agency may submit written comments on the DNS to the lead agency within 15 days from the date of issuance. If comments are received, the lead agency must reconsider the DNS. The lead agency is not required to modify the DNS, but may, however, determine that there is a significant impact and require preparation of an EIS.

Whenever the lead agency determines that there may be a probable significant adverse environmental impact, it must prepare an EIS. The EIS provides information about a proposed project and possible alternatives to the project to agency officials, project sponsors, and interested citizens. The lead agency must use a scoping process to narrow the contents of the EIS. During scoping, the lead agency consults with other agencies and the public. The lead agency then writes a draft EIS which focuses on the significant adverse impacts that may result from the project and its alternatives and discusses measures to mitigate or eliminate adverse impacts. The lead agency sends copies of the draft EIS to all agencies requiring a permit or other approval, to Indian tribes that may be affected by the project, and to interested citizens. Agencies and citizens have $\mathbf{3 0}$ days in which to comment on the draft EIS. The lead agency must give public notice for both scoping and the draft EIS.

After considering all comments on the draft EIS, the lead agency prepares a final EIS. This document includes all comments, the lead agency's response to the comments, and either the draft EIS is revised to respond to concerns expressed in the comments or corrections are made to the draft EIS. The final EIS is sent to all agencies that must make decisions on permits or other approvals.

Preparing and distributing the draft and final EIS and public hearings generally takes 3 to 6 months, but this can vary substantially. In certain cases, a joint SEPA EIS/NEPA EIS may be prepared. However, this requires close coordination with federal and state agencies. In other selected circumstances, a federal environmental assessment may be adopted by the SEPA lead agency as that agency's EIS (WAC 197-11-610).

The Environmental Permit Information Center (Center) of the Washington Department of Ecology provides a centralized statewide environmental permit information service. The Center can answer general questions and provide certain services during the process of obtaining state environmental permits for activities on state and private lands. For Washington Department of Ecology address, see Appendix 1E. 
The Center's Permit Information Line provides information on state environmental permits, public notice requirements, processing times, and appeal procedures as well as required federal and local permits. The Center can identify the agencies involved and their locations. The Center can assemble a Permit Application Packet, tailored to the specific needs of a project, and send it to an applicant.

Permits may be applied for individually, or a special process may be used to obtain several environmental permits as a package. The Environmental Coordination Procedures Act (ECPA) was adopted by the Washington State Legislature in 1973 to coordinate permit procedures. This process gives an applicant the option of submitting a Master Application form to assist in identifying necessary permits for the proposed development. If this service is used, the Center acts as the permit coordinator and assists the applicant from application through final disposition.

Not every geothermal project requires every state permit listed in Table 17. Generally, large developments require most of these; a small facility may only need three or four of the possible permits.

Approximate time estimates given for project development are just that-estimates. Time requirements will vary, depending on the complexity of the project and the amount of controversy involved. If several public hearings or court actions are involved before a permit can be issued, the length of time necessary for approval will increase substantially.

\section{Approximate Time Required for Process}

The SEPA process can take any where from 3 weeks to 3 years.

\section{Air Quality}

Air pollution control in Washington is based on a set of local, state, and federal laws and regulations involving three levels of government. The federal government, through the Environmental Protection Agency (EPA), sets air pollution standards that apply nationally. The state government, through the Washington Department of Ecology (Ecology) and, in some cases, the Energy Facility Site Evaluation Council (EFSEC), is required to implement those standards. A third level of government, local air pollution control agencies, also has broad responsibilities for implementing air pollution control activities within their single or multi-county jurisdictions. Jurisdictional boundaries of the state's nine local air pollution control agencies and addresses and telephone numbers for air quality contacts can be found in Appendix 1E. 


\section{Permit}

AgencJ

Comments

Required for the drilling of a geothermal well

Fee

Approximate Time

\begin{tabular}{lll}
\hline $\begin{array}{l}\text { Permit to Commence Drilling } \\
\text { Redrilling, or Deepening }\end{array}$ & WDNR & Required for the drilling of a geothermal well \\
\hline $\begin{array}{l}\text { State Environmental } \\
\text { Policy Act Compliance }\end{array}$ & $\begin{array}{l}\text { SEPA lead } \\
\text { agency }\end{array}$ & \\
\hline $\begin{array}{l}\text { Permit to Appropriate } \\
\text { Public Waters }\end{array}$ & Ecology & $\begin{array}{l}\text { Required for any use of water for geothermal } \\
\text { (Weneration. Permit must be obtained prior } \\
\text { to construction. I some cases an existing } \\
\text { right may be changed to geothermal use } \\
\text { upon approval by Ecology. }\end{array}$
\end{tabular}



NOTE: Most projects will not require all of the permits listed. Small projects are likely to require only a few of those permits.

* See additional information on the individual permit.

cfs - cubic feet per second

hp - horsepower 
Ecology implements and enforces several air regulations. The local air authorities implement and enforce most state regulations, and some local agencies have additional regulations that are more restrictive than those of Ecology. These additional or more stringent regulations are not addressed in this guide.

Ecology has jurisdiction over all sources located in counties that do not have activated local authorities. Additionally, Ecology has assumed jurisdiction over primary aluminum plants, pulp mills, vehicles, and vehicle-related sources.

Large new energy related resources, such as thermal plants greater than $250 \mathrm{MWe}$, are under the jurisdiction of EFSEC.

Permit or Regulation: Environmental Coordination Procedures Act (ECPA)

Statutory Authority: Chapter 90.62 RCW; Chapter 173-08 WAC

Agency: Washington Department of Ecology (Ecology)

To coordinate permit procedures, the Environmental Coordination Procedures Act (ECPA) was adopted by the Washington State Legislature in 1973. This process gives you the option of submitting a Master Application form to assist in obtaining necessary permits for a project.

\section{Permit or Regulation: New Source Construction Approval}

Statutory Authority: Chapters 43.21A and 70.94 RCW; Chapters 173-400, 173-405, 173-410, 173-415, and 173-490 WAC

Agency: Washington Department of Ecology (Ecology) or Air Pollution Control Authority (APCA)

The Washington Department of Ecology (Ecology) or the local air pollution control authority (APCA) has review and approval authority over new source construction and/or additions to existing sources releasing contaminants into the ambient air. This permit requires the listing of all source units (not including mobile equipment on the site for less than 60 days), each type of air pollution generating equipment used, air pollution control equipment, and the type and amounts of pollutants produced. Two sets of plans are required with information on the equipment and control apparatus, plot plan, and the proposed means of air contaminant control or prevention.

Approval is required for construction, installation, or establishment of a new stationary source of emissions. Within 30 days of receipt of a Notice of Construction (NOC), the reviewing authority (local Air Pollution Control Authority [APCA]), Ecology regional offices, or Energy Facility Site Evaluation Council may require additional information of the applicant.

Within 30 days of receiving all required information, the reviewing authority will make a preliminary determination. This determination will be made available in at least one location in the county(s) where the project is to be located. 
The applicant must publish a notice informing the public of the opportunity to provide written comment on the preliminary determination within 30 days of published notice.

After review of all current information, the reviewing authority issues either an order denying construction or an order of approval for construction. An order of approval may contain specific requirements and conditions. The opportunity for public hearing is necessary for proposed construction where offsetting is proposed.

The Washington Department of Ecology Environmental Permit Information Center (EPIC) can refer applicants to specific air pollution control authorities in their area.

Approximate Time Required to Obtain Approval

Approval will be given in 1 to 2 months.

Permit or Regulation: Air Contaminant Source Registration

Statutory Authority: Chapter 70.94 RCW; Chapter 173-400 WAC

Agency: Washington Department of Ecology (Ecology)

Air contaminant sources in Washington State must be registered. Air contaminant source registration classifies the levels and types of air emissions.

Permit or Regulation: Prevention of Significant Deterioration (PSD)

Statutory Authority: Chapter 43.21A RCW; Chapter 173-400 WAC

Agency: Washington Department of Ecology (Ecology)

The basic objective of the Prevention of Significant Deterioration (PSD) program is to prevent substantial degradation of air quality in areas that are in compliance with national ambient air quality standards, while maintaining a margin for future industrial growth. Each proposed new or modified air contaminant source must undergo a new source review. As part of this review, PSD applicability is determined. If PSD review is required, a PSD application must be submitted and a permit obtained before beginning project construction.

Criteria that trigger PSD vary depending on the type and amount of air contaminant(s) emitted, type of facility, and the proximity of a project to a designated Class I area. Generally, PSD review is not required for facilities that emit less than 100 tons per year of a regulated pollutant.

Specific information on PSD requirements can be found in the Code of Federal Regulations (CFR) 40 CFR 52.21, as adopted and supplemented by state statute. However, this regulation is quite complex, so it is best to contact the appropriate air authority to determine if your proposal will require PSD review. 
Permit or Regulation: Sensitive Areas

Statutory Authority: Chapter 70.94 RCW; Chapter 173-400 WAC

Agency: Washington Department of Ecology (Ecology)

Certain geographic areas within Washington State are designated as air quality Sensitive Areas after considering population, development, and recreational and scenic values. When located in Sensitive Areas, certain stationary source categories (specified by regulation) may be subject to more stringent standards and compliance requirements.

\section{Permit or Regulation: Air Pollution Standards Variance \\ Statutory Authority: RCW 70.94; 173-400 WAC Agency: Washington Department of Ecology (Ecology)}

An air pollution standards variance is issued for temporary variances from air pollution standards.

\section{Water Quality/Water Use}

Washington State has what appears to be an abundant water supply. However, because of geographic and seasonal shortages, water supplies are not always adequate or available. In addition, the total water supply is finite; there will never be more. Because Washington's population is increasing there is an expanded water demand for all purposes-domestic, industrial, agricultural, recreational, as well as power generation. The permits listed below are part of Washington's water resource management strategy.

It is Washington State's policy to "...maintain the highest possible standards to ensure the purity of all waters of the state consistent with public health and public enjoyment...the propagation and protection of wildlife, birds, game, fish and other aquatic life, and the industrial development of the state."

There are many activities during geothermal exploration and development that have the potential to impact water quality. Pollution from these and other activities can be reduced if appropriate methods are used. During the permitting process, agency experts can design the project to control and prevent pollution of streams, rivers, lakes, and other surface and groundwaters of the state.

Permit or Regulation: Groundwater Management Areas

Statutory Authority: Chapter 90.44 RCW; Chapter 173-100 WAC

Agency: Washington Department of Ecology (Ecology)

In response to the growing concern about the state's groundwater resource, the Washington Department of Ecology (Ecology) is legislatively mandated to coordinate the development of 
groundwater management programs. Local governments are responsible for developing Ecology-approved groundwater management plans. Activities within groundwater management areas are required to comply with ordinances/regulations established as part of a groundwater management plan.

\section{Permit or Regulation: Water Right}

Statutory Authority: Chapters 18.104, 43.27A, 90.03, 90.14, 90.16, 90.22, 90.44 and 90.54 RCW; Chapters 173-100, 173-136, 173-50, 173-154, 173-166, 173-500, and 173-590 WAC

\section{Agency: Washington Department of Ecology (Ecology)*}

Information required for this permit application includes the following: a section map, the source of the water supply, how the water will be used, the exact location of the point of diversion or withdrawal, a legal description of the property on which the water is to be used, the signature of the legal landowner, and a description of the proposed water system. This application should be submitted as early as possible to establish a priority date, the nature and amount of proposed use, date construction will be completed, and the date of complete application of water to beneficial use. Processing begins when an application is received by Ecology. SEPA compliance is required before issuance of this permit.

Individuals or corporations may exercise the right of eminent domain to acquire water rights or property necessary for water conveyance (see RCW 90.03 or 90.16 ).

As provided for by RCW 90.16 , any entity claiming the right to use water for power production must pay an annual fee to the state.

\section{Approximate Time Required to Obtain Permit}

Applicant should receive the permit in 18 to 24 months.

\section{Permit or Regulation: Water Well Construction and Operator's License} Statutory Authority: $18.104 \mathrm{RCW}$ Agency: Washington Department of Ecology (Ecology)

This license authorizes a person to engage in the construction of water wells for compensation. To qualify for a construction operator license the applicant must have at least 2 years of experience with a licensed well driller (or qualifying experience), and pass a written examination administered by the Washington Department of Ecology (Ecology).

All wells constructed in the state must meet the minimum standards for construction and maintenance of wells as outlined in Chapter 173-160 WAC. Documentation of well construction must be provided to Ecology in the form of a start card filed before the well is constructed.

- State permits may be applied for prior to SEPA compliance; however, most permits require SEPA compliance before issuance. 


\section{Permit or Regulation: Water Quality Certification and Modification}

Statutory Authority: Section 401, Federal Water Pollution Control Act;

Chapter 173-225 WAC/RCW 90.48.120; WAC 173-201-035(8e)

Agency: Washington Department of Ecology (Ecology)*

A Water Quality Certification is a statement issued by Ecology (Ecology) that the proposed activity will comply with applicable water quality standards and discharge limitations. Issuance of a certification is exempt from SEPA requirements.

Because most new geothermal construction activities will unavoidably violate state water quality criteria (particularly the turbidity criterion) on a short-term basis, such projects will require a Short-term Modification of Water Quality Criteria. A modification may be required before Ecology can issue a Water Quality Certification. SEPA compliance is required for a modification.

To request a certification and/or modification, a letter containing the following information should be sent to Ecology: project description, including location and proposed activities; and the nature of any water quality violation expected, including specific criteria which will be violated, the scheduled duration and extent of these occurrences and methods proposed to minimize the impact on water quality. Depending on the project, a review of plans and specifications may also be required.

\section{Approximate Time Required to Obtain Certification}

This process could take any where from 2 months to one year.

\section{Permit or Regulation: Geothermal Drilling}

Statutory Authority: Chapter 79.76 RCW; Chapter 332-17 WAC

Agency: Washington Department of Natural Resources (WDNR), Division of Geology and Earth Resources

This permit regulates drilling for geothermal energy. A bond is required before permit approval is granted.

Permit or Regulation: Commence Drilling, Redrilling, or Deepening

Statutory Authority: Chapter 79-76 RCW; Chapter 332-17 WAC

Agency: Washington Department of Natural Resources (WDNR), Division of

Geology and Earth Resources

The application to the Washington Department of Natural Resources (WDNR) for a Permit to Commence Drilling, Redrilling, or Deepening a geothermal well on state or private land requires information on: the proposed location of the well(s) including the position of any associated equipment; description of the lease, or property and owners of surface and mineral rights; exist-

* Applications and letters of request should be sent to the appropriate regional office of Ecology. 
ing and planned roads; methods for disposing of waste materials, including cuttings and drilling fluid; and additional information addressed in the WAC. The applicant must have blowout prevention equipment installed. The applicant must obtain a drilling bond prior to starting to drill.

\section{Approximate Time Required to Obtain Permit}

It will take 6 to 12 weeks to obtain the permit.

\section{Permit or Regulation: Drilling Bond}

Statutory Authority: Chapter 79.76 RCW; Chapter 332-17-160 WAC

Agency: Washington Department of Natural Resources (WDNR), Division of

\section{Geology and Earth Resources}

The owner or operator who proposes to drill, redrill, or deepen a well for geothermal resources shall file with the Washington Department of Natural Resources (WDNR) a good and sufficient bond of $\$ 15,000$ for each well or a $\$ 50,000$ blanket bond for one or more wells being drilled, redrilled, or deepened at any time. The bond must be filed with WDNR at the time application is made to drill, redrill, or deepen a well or wells. Approval of the bond by WDNR must be obtained prior to starting drilling, redrilling, or deepening. The bond should be made payable to the state of Washington, conditioned for performance of the duty to properly:

1. drill all geothermal wells

2. operate and maintain producing wells

3. plug each dry or abandoned well in accordance with applicable rules and regulations of the department

The bond must be executed by the owner or operator as principal and by a surety company authorized to do business in the state of Washington as surety, conditioned upon the faithful compliance by the principal with the laws, rules, regulations, and orders under the Geothermal Resources Act. The bond's principal secures the state against all losses, charges, and expenses incurred by the state in obtaining such compliance.

A single core-hole bond must be for $\$ 5,000$, and a blanket core-hole bond must be for $\$ 25,000$.

\section{Permit or Regulation: Underground Injection Control Program}

Statutory Authority: Chapter 90.48 RCW; Chapter 173-218 WAC

Agency: Washington Department of Ecology (Ecology)

A permit is required for the injection of geothermal fluids into a well (Class $\mathrm{V}$ injection well). The applicant is required to submit geothermal fluid quality data. The purpose of the program is to preserve and protect the quality of the state's groundwater as it pertains to public health and welfare. 
Permit or Regulation: National Pollutant Discharge Elimination System (NPDES)

Statutory Authority: Chapter 90.43, 90.50, and 90.52 RCW; Chapter 173-220 WAC Agency: Washington Department of Ecology (Ecology)

A National Pollutant Discharge Elimination System (NPDES) permit is required where a waste water source is discharged to "waters of the United States." In lieu of holding such a permit, a state discharge permit is required under provisions of RCW 90.48.160-.162.

The application requires information on waste source flow and expected characteristics, disposal method, water supply, waste water disposal, water supply volumes, water utilization, planned improvements, storm water treatment, plant operation, materials and chemicals used, and production. Prior SEPA compliance is required.

Approximate Time Required to Obtain Permit

Two to 6 months is required to obtain this permit.

\section{Permit or Regulation: Hydraulic Project Approval}

Statutory Authority: RCW 75.20.100

Agency: Washington Department of Fisheries (WDF); Washington Department of Wildlife (WDW)

The application for this permit requires information on construction schedule, activities, methods, impact mitigation, total project cost, equipment, and duration of activities in and around steams and lakes. Information is also needed on any proposed changes in the channel bed or configuration, alterations of the stream bank vegetation, water quality impacts, restoration methods for vegetation and stream channel, fish protection, and siltation and erosion controls. Prior SEPA compliance is required.

\section{Approximate Time Required to Obtain Permit}

It should take approximately 45 days to receive this permit.

\section{Land Use}

The Washington Department of Natural Resources (WDNR), under the direction of the Commissioner of Public Lands, administers many permits regulating the use of over 12.5 million acres of state and private land. Forest practices enforcement, surface mine regulation, and administration of other land resource permits, are among the WDNR's responsibilities. The Department of Community Development and the Office or Archaeology and Historic Prevention are charged with protecting historic and archaeological resources in the state. 


\section{Permit or Regulation: Section 106 Review \\ Statutory Authority: 36 CFR 800; PL 89665 \\ Agency: Washington Department of Community Development (WDCD); \\ Washington Office of Archaeology and Historic Preservation (WOAHP)}

State and federal law protects historical and archaeological sites as well as National Register properties. The Washington Office of Archaeology and Historic Preservation (WOAHP) has responsibility for reviewing the impacts of proposed projects and any avoidance, mitigation, or protective measures proposed by the applicant. A report on the cultural resources located in the project area must be included in the license or exemption application. Assistance in preparing this report can be obtained from the WOAHP.

\section{Procedures for Review of Federal Projects}

After receiving a notification of a project, the WOAHP will check inventory and survey records to determine if surveys have been conducted and whether archaeological sites or historic properties have been identified in the project area.

Based on the nature of the project and on the project's location, the OAHP will usually make one of the following comments (these comments technically are addressed to the federal agency, even though in some cases the federal agency requires private individuals to obtain OAHP comments):

1. Archaeological and historic surveys have determined there are no archaeological or historic properties in the proposed area. The project will have no effect.

2. Based on the nature of the project and its location, it is unlikely the project will affect archaeological or historic properties. However, if archaeological materials (arrow points, bottles, etc.) are found during construction, the WOAHP should be contacted.

3. Based on the nature of the project and its location, it is likely, but not confirmed, that National Register properties occur in the project area and could be affected by the project. The agency should have the area inspected by a professional archaeologist, historian, or architectural historian, as appropriate, to locate and evaluate any archaeological sites and historic properties in the area. This work should follow the Secretary of Interior's guidelines for historic preservation projects.

4. There has been a survey in the area, and archaeological sites or historic properties have been recorded. Following National Park Service standards, the agency should determine which sites or properties are eligible for the National Register.

5. National Register properties will be adversely affected by the project, and the agency should obtain the comments of the Advisory Council on Historic Preservation.

In some cases, professionals from the WOAHP will inspect a project area to help a private firm or individual comply with federal preservation laws. If a project requiring federal approval or a 
federal license is not on federal land, is not federally funded, and if it is less than 25 acres in size the WOAHP will consider inspecting the project at no cost to the applicant. The decision depends on available personnel and funding.

The WOAHP maintains a log of the projects reviewed and the commients made.

Normally 30 days is allowed for the WOAHP to comment on federal projects. If the WOAHP has not commented in this period, the Agency can proceed with the Section 106 process. Allowances are made in cases where the normal review period would cause a delay in a project.

Approximate Time Required for Review

The review period will take approximately 2 months.

Permit or Regulation: Geothermal Leasing on State Trust Land

Statutory Authority: $\mathrm{RCW}$ 79.01.096

Agency: Washington Department of Natural Resources (WDNR)

A geothermal lease to conduct geothermal exploration and development activities on state land managed by the Washington Department of Natural Resources (WDNR) is issued on a competitive basis. Each geothermal lease on state land is processed on an individual basis; no rules and regulations pertaining to lease fees and royalty schedules have been adopted. The WDNR Division of Land Leasing and Recreation in Olympia is responsible for processing and issuing geothermal leases on state trust lands.

Permit or Regulation: Surface Mining

Statutory Authority: RCW 78.44.080

Agency: Washington Department of Natural Resources (WDNR)

A bond may be required for reclamation activities before this permit is granted. Engineering information required includes: topographic maps, location of disposal and borrow sites, construction methods, equipment, mitigation plans for runoff and erosion, and the proposed schedule. Environmental information required includes soil characterization, erosion control measures, reclamation and revegetation plans, and methods to protect surface water quality. The status of other state and local permits should also be given. SEPA compliance is required prior to issuance.

Approximate Time Required to Obtain Permit

It will take approximately 2 to 3 months to receive this permit. 
Permit or Regulation: Dumping Permit

Statutory Authority: RCW 76.04.242

Agency: Washington Department of Natural Resources (WDNR)

After a dumping area has been established; the Washington Department of Natural Resources (WDNR) is contacted and an inspector sent; the permit will be issued at the site. The inspector should be provided with a description of the dumping location and information regarding dumping practices and fire safety precautions.

\section{Approximate Time Required to Obtain Permit}

This should only take 1 week.

\section{Permit or Regulation: Right-of-Way or Road Use}

Statutory Authority: RCW 79.01.384 and 79.01.388

Agency: Washington Department of Natural Resources (WDNR)

Applications for the right to use state lands are available at the Washington Department of Natural Resources (WDNR) headquarters or the local regional office. A separate application must be filed for each easement. The fair market value of any timber cut will be assessed and any costs incurred for a timber sale will be charged to the applicant.

Plans and sketches showing the location and design of all new construction must be submitted. Also needed are the locations, on plats, of new construction, a description of the engineering involved, and a description of the environmental impacts. SEPA compliance is required prior to issuance.

\section{Approximate Time Required to Obtain Easement}

It will take approximately 2 months to receive each easement.

\section{Permit or Regulation: Application to Purchase Valuable Material \\ Statutory Authority: $R C W 79.01 .124$ and 79.01.132 \\ Agency: Washington Department of Natural Resources (WDNR)}

A standard application form can be obtained from the Washington Department of Natural Resources (WDNR). It will evaluate the fair market value for a purchase price. The legal location of the pit or quarry, excavation method proposed, the location of any timber stands or state quarries, the proposed excavation time, the planned use of the material, and the reclamation plan should also be provided with the application. SEPA compliance is required prior to issuance.

\section{Approximate Time Required to Obtain Permit}

The permit process should take approximately 2 months. 


\section{Permit or Regulation: Temporarily Remove or Destroy Survey Monument \\ Statutory Authority: Chapter 332-120 WAC \\ Agency: Washington Department of Natural Resources (WDNR)}

This permit is issued by the Washington Department of Natural Resources (WDNR) subject to the provisions of Chapter 332-120 WAC, which requires adequate referencing and replacement of the monument or reference monuments after the development has been completed. A description of existing conditions and reason for removal are required. Coordination with the Washington Coordinate System may be required.

\section{Approximate Time Required to Obtain Permit \\ This permit should only take about 1 week.}

\section{Permit or Regulation: Archaeological Excavation}

Statutory Authority: Chapters 27.44 and 27.53 RCW; Chapter 25-48 WAC

Agency: Washington Department of Community Development (WDCD), Washington Office of Archaeology and Historic Preservation (WOAHP)

The Washington Department of Community Development (WDCD), Washington Office of Archaeology and Historic Preservation (WOAHP) should be contacted prior to the start of the project to determine if historic or archaeological sites will be affected. A historic/archaeological excavation assessment may be required. A permit from WDCD, WOAHP, must be obtained prior to any excavation that will alter or remove Native Indian grave site or archaeological resources.

The status of any sites or structures listed in or eligible for the State or National Register of Historic Places or Local Landmark designation may need to be determined. Plans for protection of mitigation measures may be a condition of any permit issued.

\section{Permit or Regulation: Archaeological Approval} Statutory Authority: Executive Order 11593 Agency: Washington Office of Archaeology and Historic Preservation (WOAHP)

The Washington Office of Archaeology and Historic Preservation (WOAHP) should be contacted prior to the start of a project. A historic/archaeological assessment may be required at the project site. The status of any sites or structures that are listed for the National Register of historic places will be identified. The number and extent of any resources that are present and their scientific importance will be determined. Plans and procedures will be outlined for recovery or mitigation of adverse effects. This approval is required prior to obtaining federal permits or licenses and SEPA approval.

Approximate Time Required to Obtain Approval

This process will take approximately 2 months. 


\section{Permit or Regulation: Forest Practices Approval}

Statutory Authority: RCW 76.09.060; Title 222 WAC

Agency: Washington Department of Natural Resources (WDNR)

This approval is required of the bona fide owner/operator of land before beginning any forest practice (harvesting, reforestation, road construction, etc.).

Information is required on the location of the construction activities, the borrow and disposal areas, the construction methods and equipment, the size of needed rights-of-way, the restoration plans, the drainage plans, and an evaluation of the wildlife habitat to be removed.

Depending on the class of forest practice involved (see WAC 222-16-050), this permit may be contingent on the granting of Hydraulic Project Approval, Shoreline Substantial Development permit, Water Quality Certification, and SEPA compliance.

Approximate Time Required to Obtain Approval

Approval should be received in $\mathbf{5}$ to $\mathbf{3 0}$ days.

\section{Construction}

\section{Permit or Regulation: Special Motor Vehicle}

Statutory Authority: $R C W$ 46.44.090

Agency: Washington Department of Transportation (WDOT)

This permit may be issued by the Washington Department of Transportation (WDOT) at the time of application for activities using oversized or overweight vehicles. Information on tire size, number of tires, the weight and size of the vehicle, and the current registration must be supplied. The permit may be applied for by the contractor or by the developer.

\section{Approximate Time Required to Obtain Permit}

This permit should be obtained in 1 day.

\section{Permit or Regulation: Burning}

Statutory Authority: RCW 76.04.150

Agency: Washington Department of Natural Resources (WDNR)

This permit should be applied for after construction, when the contractor has piled all debris for burning and fulfilled all safety precautions. An inspector will be sent to examine the site; if it is safe, a permit will be issued at the site.

\section{Approximate Time Required to Obtain Permit}

This process will take 1 week. 


\section{Permit or Regulation: Flood Control Zone}

Statutory Authority: RCW 86.16.080

Agency: Washington Department of Ecology (Ecology)

This permit is required for the construction of any new structure, or the reconstruction or modification of an existing structure within designated flood control zones. Permit applications should include plans showing dimensions and elevations of planned obstructions and provisions for water passage through, around, and over works. Known high water marks and dates should also be included.

The counties of King, Cowlitz, Skagit, Kittitas, Clallam, Thurston, and Clark administer the flood control zone permit systems within their county boundaries. Applications for permits in these counties should be made through the local building or planning department, or through contacting the nearest Washington Department of Ecology Regional Office listed in Appendix 1E. This permit may require SEPA compliance.

\section{Approximate Time Required to Obtain Permit}

It will take approximately 1 month to obtain this permit.

\section{Permit or Regulation: Waste Water Facilities Plan Approval Statutory Authority: RCW 90.48.110; Chapter 173-240 WAC Agency: Washington Department of Ecology (Ecology)}

Engineering reports, plans, and specifications for construction of new sewage or industrial waste treatment or disposal systems, including systems for erosion/sedimentation control, disposal of waste water from concrete batching and coring, etc., must be submitted for review and approval by the Washington Department of Ecology. Prior SEPA compliance is required.

\section{Safety/Health}

This section deals with regulations designed to protect public health and safety. Included are a number of permits dealing with hazardous, dangerous, and solid waste. The Washington Department of Ecology has several programs devoted to managing waste to protect public health and the environment.

\section{Permit or Regulation: Public Water Supply Approval}

Statutory Authority: Chapters 248-54, 248-56, and 440-44 WAC Agency: Washington Department of Social and Health Services (WDSHS)

This approval is given in two parts. First is a preliminary design review that takes 60 days; second, a final plans and specifications review that takes 30 days. See WAC 248-54, -085, and -095 for details. After construction is completed, there will be a final review of the approved 
plans and the as-built drawings to see if there are any significant changes. Ultimate approval is subject to SEPA compliance. The preliminary design should be tumed in as soon as possible, and the final plans turned in shortly before SEPA compliance to allow for review time.

Approximate Time Required to Receive Approval

Approval should be obtained in 3 months.

\section{Permit or Regulation: On-Site Sewage Disposal}

Statutory Authority: Chapter 90.48 RCW; Chapter 173-240 WAC

Agency: Washington Department of Ecology (Ecology) and Washington Department of

Social and Health Services (WDSHS) or Local Health Department

Businesses and residences that locate outside areas served by sewer systems frequently treat and dispose of sewage on the property where it originates through septic tanks and subsurface disposal fields. These systems are reviewed and approved by local health departments, the Washington Department of Social and Health Services (WDSHS), or the Washington Department of Ecology (Ecology) depending on the size and nature of the system.

Local health departments issue permits for on-site sewage with design flows, at any common point, less than 3,500 gallons/day.

WDSHS reviews and approves plans and specifications for on-site sewage systems with design flows, at any common point, between 3,500 gallons/day and 14,500 gallons/day. Local health departments can take on this responsibility with a contractual agreement with WDSHS.

Ecology reviews and approves plans and specifications for on-site systems exceeding 14,500 gallons/day, all systems receiving state or federal construction grants under the Clean Water Act and systems using mechanical treatment or lagoons with ultimate design flows above 3,500 gallons/day. Ecology regulations generally require public ownership, operation, and maintenance of domestic waste water facilities.

\section{Permit or Regulation: Sewage Holding Tank Variance}

Statutory Authority: Chapter 248-96 WAC revised (6/92); Chapter 246-272 WAC Agency: Washington Department of Social and Health Services (WDSHS);

\section{Local Health Department}

An application for this permit can be obtained from the local Health Department. The following should be included with the application: a drawing of the proposed facility including location and size; information on maintenance schedules; precautions to be taken against overflow; and a signed contract with a holding tank pumping firm that indicates a servicing schedule and a backup pumping firm. 
Permit or Regulation: Public Water Supply Approval

Statutory Authority: Chapter 248-54 WAC

Agency: Washington Department of Social and Health Services (WDSHS)

This approval is given in two parts. First is a preliminary design review that takes 60 days; second, a final plans and specifications review that takes 30 days. See WAC 248-54, -085, and -095 for details. After construction is completed, there will be a final review of the approved plans and the as-built drawings to see if there are any significant changes. Ultimate approval is subject to SEPA compliance. The preliminary design should be turned in as soon as possible, and the final plans shortly before SEPA compliance to allow for review time.

Approximate Time Required to Receive Approval

Approval should be obtained in 3 months.

Permit or Regulation: State Waste Discharge Permit

Statutory Authority: Chapters 90.48, 90.52, 90.54 RCW; Chapters 173-216 and-224 WAC Agency: Washington Department of Ecology (Ecology)

Through these permits, the Washington Department of Ecology (Ecology) regulates the discharges or disposal of industrial, commercial, or municipal waste material into the state's groundwaters, and the discharge of industrial or commercial wastes into municipal sewer systems.

The permit application requires information on water supply volume, water utilization, wastewater flow, characteristics and disposal methods, planned improvements, storm water treatment, plant operation, materials and chemicals used, production, and other relevant information.

Ecology generally requires public ownership, operation, and maintenance of domestic wastewater facilities.

\section{Approximate Time Required to Obtain Permit}

This permit should take 2 to 6 months to obtain.

\section{Permit or Regulation: Wastewater Facilities Plan Approval Statutory Authority: RCW 90.48.110 and Chapter 173-240 WAC Agency: Washington Department of Ecology (Ecology)}

Engineering reports, plans, and specifications for construction of new sewage or industrial waste treatment or disposal systems, including systems for erosion/sedimentation control, disposal of wastewater from concrete batching and coring, etc., must be submitted for review and approval by the Washington Department of Ecology. Prior SEPA compliance is required. 
Permit or Regulation: Identification Number/Reporting Requirements (Hazardous Waste) Statutory Authority: RCW 70.105; Chapter 173-303 WAC

Agency: Washington Department of Ecology (Ecology)

An EPA/State identification number is required for persons who generate, transport, or offer for transport hazardous wastes going to a storage, treatment, and/or a disposal facility.

An annual reporting of hazardous waste management activities is required of the owner or operator of a facility that has an active EPA/State identification number.

\section{Permit or Regulation: Hazardous/Dangerous/Solid Waste}

Statutory Authority: Chapter 70.105 RCW; Chapter 173-303 WAC

Agency: Washington Department of Ecology (Ecology)

The Washington Department of Ecology (Ecology) is responsible for identifying, investigating, and cleaning up hazardous waste sites. Any contaminated site must be reported, by the facilities' owner or operator, to Ecology. Facilities found contaminated and that require remedial action are placed on a hazardous waste site list maintained by Ecology. Contaminated sites must be cleaned up in accordance with state standards. Cleanups may be done independently (without Ecology oversight or approval); however, all cleanups must be reported to Ecology and are subject to later review. For this reason, owners and operators are encouraged to contact Ecology to develop an approvable testing and cleanup plan.

\section{Permit or Regulation: Hazardous Waste Release Notification}

Statutory Authority: Chapter 70.105 RCW; Chapter 173-303 WAC

Agency: Washington Department of Ecology (Ecology)

Prompt notification to the Washington Department of Ecology (Ecology) is required when spills or releases of hazardous substances occur that have the potential to impact human health or the environment. Responsibility for reporting spills lies with the person who spills or releases the substance; however, any person aware of such spills is encouraged to contact Ecology.

\section{Permit or Regulation: Certificate of Designation}

Statutory Authority: Chapter 70.105 RCW; Chapter 173-303 WAC

Agency: Washington Department of Ecology (Ecology)

A certificate of designation is issued for voluntary review of potentially hazardous waste. The function of the certificate is to determine designation of waste (Dangerous, Extremely Hazardous, or Undesignated). 


\section{Permit or Regulation: Underground Storage Tank Notification Requirement}

Statutory Authority: 40 CFR 280.22; Chapter 90.76 RCW

Agency: Washington Department of Ecology (Ecology)

If developer has installed or intends to install an underground storage tank (UST), a state UST notification form must be completed. This form is available from the Washington Department of Ecology (Ecology). Ecology administers a federal requirement to report regulated underground storage tanks and information about these tanks.

Currently, under federal requirements, notification is required within $\mathbf{3 0}$ days of putting into service a new tank.

\section{Local Permitting and Licensing Requirements}

Local governments such as cities, counties, road districts, flood control districts, and drainage districts will have some jurisdiction over geothermal development in nearly all cases. Most county govemments require building permits for construction and entail building code, electrical code, and plumbing code compliance. Counties also have planning and zoning commissions that will review project plans for compliance with comprehensive plans, zoning regulations, and needs for conditional or special use permits. Counties may also have some jurisdiction over construction in or near defined flood plains and over use of, or construction near, county highways. The county courthouse, the county zoning administrator, and the county highway district are the best contacts for determining what permits or approvals will be required.

If a proposed site is within a city's limits or within its area-of-impact, appropriate contact should be made with city officials regarding building permits, zoning regulations, flood plain construction, and highway usage. Contact the city hall of the nearest city for a determination of the required permits and approvals and jurisdiction.

Smaller communities often issue all permits through a single office, such as the Clerk. In some counties, one or more highway districts exist that are responsible for construction and maintenance of roads. These agencies will be the administrators of all permits/approvals having to do with public rights-of-way.

A number of these permits, mainly those administered by the local planning department, will involve substantial discretionary action on the part of the decision makers, approval being based on conformance of plans with established criteria or standards. Therefore, these decisions will usually be made by elected or appointed officials (city councilmen, county commissioners, or planning and zoning commissioners). Another group of approvals will be based on the adequacy of technical plans. These will generally be the permits listed as being administered by the public works department and building department. Several items will be simply a matter of registration, including the business license and registration of proprietorship. The following is a general description of each of the permits and approvals which may be required. 
Within the framework of federal and state regulation, local governments perform duties which can have unique and significant impacts on energy project development. Local governments can set an example by financing and developing energy facilities themselves. They can encourage private development through information distribution and active recruiting of facilities. Cities and counties also regulate energy facilities. Below state-level citing thresholds, the jurisdictions are the primary development permitting authority. They set land use policy which controls the type and location of future development and affect construction techniques by enforcing building and electrical codes. They direct the division of lots through subdivision ordinances. They also regulate the type, mix, and location of land uses using zoning ordinances.

Zoning ordinances implement policies established in local land use plans and reduce land use conflicts by dictating: 1) the type of development allowed within the jurisdiction; 2) the design of those uses; and 3 ) the way potentially conflicting uses may coexist.

Policies and standards reflect both technical information and popular opinion. Local land use law often reflects values that are difficult to evaluate objectively. Public participation in a project approval may reveal concerns for property values, neighborhood quality, and scenic quality. These subjective values are difficult to put into laws. Few local governments have done more with energy facility regulation than provide a forum for public involvement in siting decisions.

In some states, counties and incorporated cities prepare and adopt comprehensive land use plans which are acknowledged by a state-level commission. The plans indicate the location and significance of affected resources and provide a regulatory framework for potentially using them. If a conflict is identified which is resolved against energy resource development, then another site must be found, unless the plan is amended. If the conflict is resolved in favor of energy resource development then, from a land use perspective, resource use is feasible. Development still may be subject to conditions which mitigate negative impacts. These requirements are described in the plan and local ordinances. Thus, developers can use comprehensive plans to learn what kind of projects might be feasible, and under what conditions.

Some counties discuss renewable resources in their comprehensive plans. However, discussion in the plans has often not led to zoning and ordinances. Frequently, adequate and up-to-date data on resources' location, quantity, and quality has not been given to local governments. Also, energy issues are not a priority in land use planning circles or most local governments.

In the absence of attention to the energy resource in the local land use plan, a prospective developer may have to champion a project proposal through the entire land use planning, zoning, and ordinance-writing processes. Such an effort would add many months to a project's lead time and increase its cost. Along the way, design changes are likely or the project may be found infeasible. The local government and public would be involved in broad planning, policy-making, and ordinance issues in the context of community reaction to a proposed project. 


\section{Determining Which Permits are Required}

To enable a developer to determine what local permits are necessary for a particular site, and for guidance in obtaining local permits, the following guidelines are provided.

- Determine with certainty within what local jurisdiction the project site lies. Assumptions about jurisdiction are often inaccurate. Even if a site is within the county, it is possible it may be within a city's Area of Impact, which would give the city certain jurisdiction over the project.

- Contact agency staff early to obtain information about permits and to discuss your plans. Go into their office in person to make personal contact and to show your commitment to expediting the permitting process.

- Determine what permits will be required for the proposed project; what information should be provided; the process that will be followed; and time frames, including submittal dates, hearing dates, and the time within which a decision can be expected.

- Get copies of the applicable regulations so you can personally review them and the evaluation criteria. Ask questions if the written regulations vary from information the staff has provided.

- In the case of more discretionary permits, ask the staff about the likelihood of approval; also what might help to speed up the process and decision.

- Submit a complete application. Incomplete applications will result in processing delays.

- Attend all meetings where the application will be discussed. If there is no one to respond to questions, delays may occur or the permit may be denied.

Local county or city government is responsible for regulating development within local jurisdiction community. The following will provide general information and directions to the appropriate local offices for obtaining local permits and approvals required for a project. These requirements pertain to local zoning and building codes, comprehensive land use and shoreline plans, and local development policies.

Local jurisdictions can encourage geothermal development by adopting specific ordinances which give clear direction to the developer as to requirements for local regulation compliance.

The permits at the local level that are applicable to geothermal development concern primarily construction-related activities. 


\section{Water Quality/Water Use}

\section{Permit or Regulation: On-Site Sewage Disposal Permit}

Statutory Authority: Chapter 90.48 RCW; Chapter 173-240 WAC

Agency: Local Health Department, Washington State Department of Social and

Health Services (WDSHS), or Washington Department of Ecology (Ecology)

Businesses and residences that locate outside areas served by sewer systems frequently treat and dispose of sewage on the property where it originates through septic tanks and subsurface disposal field. These systems require approval of local health departments, Washington Department of Social and Health Services, or the Washington Department of Ecology, depending on the size and nature of the system. Local health departments issue permits for on-site sewage with design flows, at any common point, less than 3,500 gallons/day.

\section{Permit or Regulation: Surface Water Drainage Plan Approval}

Statutory Authority: NA

Agency: Local Public Works Departments

The exact form required for this approval can be found in the local public works department Procedures Manual. A Preliminary Drainage Review of the natural and planned drainage improvements is prepared and used to determine if a Detailed Drainage Review is necessary.

A Drainage Plan Approval is needed prior to issuance of the following permits: Building, Grading, and Shoreline Development. The Preliminary Approval is sufficient for the Shoreline Development Permit hearings. There is no fee for the Preliminary Approval. The fee for the Detailed Review is based on the fee schedule for the associated local permits and approvals requiring the Drainage Plan. Prior to any site work, an inspection fee is required.

\section{Land Use}

\section{Act: Shoreline Management}

Statutory Authority: RCW 90.58.140; Chapters 173-14 through -28 WAC Agency: Washington Department of Ecology (Ecology) and Local Planning Department

To determine whether this permit is needed, the Shoreline Master Program at the pertinent county or city office should be consulted. The plan will specify whether geothermal is an allowed use for the proposed area. The procedure for obtaining this permit varies from county to county. Generally, a public hearing is required. The Hearing Examiner will require an affidavit of public notice, a location map, a topographic map, and a site map. If a variance or conditional use permit is required, the Washington Department of Ecology (Ecology) must give the final approval. SEPA compliance must be shown before final approval will be given. 


\section{Permit or Regulation: Floodplain Development}

\section{Statutory Authority: Chapter 86.16 RCW; Chapter 173-158 WAC}

\section{Agency: Local Planning Department}

Local governments participating in the National Flood Insurance Program (NFIP) are required to review proposed construction projects to determine if they are in identified floodplains as shown on the NFIP maps. If a project is located in a mapped floodplain, the local government must require a development permit to be obtained prior to construction.

Proposed projects are reviewed and conditions imposed on any permits issued to reduce the potential for damage from floodwaters. Permits are required for structures as well as for filling or grading activities in the floodplain.

State law requires that local entities have a local floodplain ordinance that meets or exceeds NFIP requirements. The Washington Department of Ecology has approval authority over these ordinances.

For permit applications or additional information, contact the local city or county building or planning department.

\section{Permit or Regulation: Zoning Conditional Use/Zoning Code Variance Agency: County Boards of Commissioners, County Department of Public Works}

In counties where a master plan is being implemented and where a project would conflict with planned land uses, a Conditional Use Permit or variance is required. The application is reviewed by a Hearing Examiner and requires a public hearing conducted by the Board of Commissioners. A preliminary drainage plan must be approved by the County Public Works Department prior to a public hearing for the substantial development and zoning permits.

\section{Construction}

\section{Permit or Regulation: Utility}

\section{Agency: Local Department of Public Works}

A letter requesting this permit should be sent to the local Department of Public Works. It should include a set of plans relating to the transmission line leading from the power house to the intertie, a description of the proposed construction of the transmission line, and a construction schedule. 


\section{Permit or Regulation: Operate Overweight Vehicles on City or County Roads Agency: Local Department of Public Works}

This permit may be obtained by the contractor. The following information is required for each application: 1) the size and number of tires; 2) weight of vehicle; and 3) the current registration of the vehicle.

\section{Permit or Regulation: Commercial Building}

Agency: Local Planning Department, Building Permit Agency

Permits to construct permanent buildings or additions to existing facilities are required by counties and cities. The application requires detailed final design plans for structures including electrical plan, plumbing plan, floor layout, sewage facilities, drainage plan, size and shape of lot and buildings, size and shape of foundation walls, beams, air vents, window accesses, and heating or cooling plants, if included in the design. Four sets of detailed plans and specifications must be included in the application.

The Building Permit is dependent on the approval of the Drainage Plan, Shoreline Development Permit, Zoning Variance, and SEPA compliance (the last two may or may not be required).

\section{Permit or Regulation: Plumbing, Electrical, Mechanical} Agency: Local Building Permit Agency

Plumbing, electrical, and mechanical plans prepared by a licensed plumber, electrician, engineer, or architect should be submitted along with an application card. The plans should show all fixtures that will be installed, the types and sizes of pipe, cable, etc., that will be used. A list of fixtures should also be included.

\section{Permit or Regulation: Grading Permit Agency: Local Planning Department}

Plans and specifications containing the following information should be submitted: the nature, extent, location, and compliance with the Uniform Building Code; existing contours, terrain, and area of drainage; limiting dimensions, contours, and proposed drainage channels after construction; plans and maps for all drainage devices, walls, cribbing, or dams; estimated area runoff; and the location of any existing or proposed building in the grading area. A Soil Engineering Report, the status of SEPA compliance and other local permits, and the Surface Water Drainage Plan should also be included.

This permit cannot be issued until SEPA compliance is established. 


\section{Permit or Regulation: Interlocal Agreement for Construction on County Roads Agency: Local Department of Public Works}

The applicant initiates the short-term agreement by sending a letter to the director of the Department of Public Works describing the intended use and proposed upgrading and maintenance work. The letter should contain a draft contract for the agreement between the county and the applicant. The letter should include descriptions of proposed road construction, drawings illustrating materials to be used, and road bed and drainage design. A copy of the state environmental checklist or SEPA document should also be included.

\section{Permit or Regulation: Temporary Road Closure Agency: Local Department of Public Works}

This permit can be granted over the counter to the contractor 5 days before it is needed. The application calls for a description of the proposed activity, the construction schedule, and the exact location of the proposed road closure.

\section{Other Permits}

Permit or Regulation: Noise Ordinances

Statutory Authority: Chapter 173-60 WAC

Agency: Local Planning Department

Noise abatement and control is primarily the role of local government, and many local entities have adopted noise ordinances. Chapter 173-60 WAC, Maximum Environmental Noise Levels, establishes noise levels that cannot legally be exceeded. Permissible noise levels established by this regulation vary depending on the source of noise (residential, commercial, industrial), and source receiving the noise. For more information about noise ordinances that apply in your area, contact your local planning department. 


\section{References}

Bain, D., 1989, Development Framework for PURPA Resources in Oregon, Oregon Department of Energy, Salem, OR, p. 107.

Bloomquist, R. Gordon, et al., 1980, Washington: A Guide to Geothermal Energy Development, Washington State Energy Office.

Bloomquist, R. Gordon, 1985, Evaluation and Ranking of Geothermal Resources for Electrical Generation or Electrical Offset in Idaho, Montana, Oregon, and Washington, Vol. I and II, Washington State Energy Office.

Bloomquist, R. Gordon, 1986, A Review and Analysis of the Adequacy of the U.S. Legal, Institutional, and Financial Framework for Geothermal Development, Geothermics, Pergaman Press Ltd.

Brown, Jovana J., 1991, Indian tribes are playing a more important role in environmental decision making in the Northwest, Northwest Public Power Bulletin, July, p. 12.

Clark, 1985, Personal Communication.

Feuer, Jack, 1990, Personal Communication.

Fujimoto, 1985, Personal Communication.

Fujimoto, 1990, Personal Communication.

Geothermal Power Company, Inc., 1981, Cycloform Scrubber steam cleaning and $\mathrm{H}_{2} \mathrm{~S}$ removal system: Elmira, New York, 7 p.

Mohorich, L.M., 1985, Personal Communication.

Mohorich, L.M., 1988, Section 115: How to Get There from Here. Geothermal Resources Council Transactions, Vol. 12, pp 329-331.

Mohorich, L.M., 1991, Personal Communication.

Offord, 1990, Personal Communication.

Perlmutter and Birkby, 1980, Montana Geothermal Institutional Handbook: A Users Guide of Agencies, Regulations, Permits, and Aids for Geothermal Development, Montana Department of Natural Resources and Conservation, Renewable Energy Bureau, 91 p.

Sacarto, Douglas M., 1976, State policies for geothermal development-uncovering a major resource: National Conference of State Legislatures, $94 \mathrm{p}$.

U. S. Geological Survey, 1979, Geothermal Steam Act of 1970 and Regulations on the Leasing of Geothermal Resources, Title 30, Chapter II of the Code of Federal Regulations and Title 43, Chapter II of the Code of Federal Regulations, U.S. Department of the Interior, $51 \mathrm{p}$. 


\section{Glossary}

\section{A-95 REVIEW}

ACDP

ADVISORY COUNCIL ON HISTORIC PRESERVATION

AIR QUALITY

MAINTENANCE AREA

ALTERNATING CURRENT
(AC)

AMICUS CURIAE

AMW

AQMA

ARCHAEOLOGICAL RESOURCE

ARCHAEOLOGY
State coordinated review of federally funded projects.

Air Contaminant Discharge Permit.

The 19 member Council is composed of a Chairman, Vice Chairman, six other private citizen members, a governor, and a mayor-all appointed by the President of the United States. The Council also includes the secretaries of the Interior and Agriculture, the heads of four federal agencies designated by the President (currently Treasury, HUD, Transportation, and the Office of Administration), the Architect of the Capitol, the Chairman of the National Trust for Historic Preservation, and the President of the National Conference of State Historic Preservation Officers. The Council members usually meet four times during the year. Day-to-day business of the Council involving Section 106 review is conducted by an Executive Director and a professional staff of historians, architects, archaeologists, planners, lawyers, and administrative personnel. The Advisory Council on Historic Preservation formulates the procedures for the protection of historic sites that all federal agencies have to follow, and through Section 106 of the Historic Preservation Act of 1966 the Advisory Council ensures compliance.

Specific populated area where air quality is a problem for one or more pollutants. (Portland-Vancouver, Salem, Eugene-Springfield, Medford-Ashland). AQMAs encompass non-attainment areas.

Electricity that reverses its direction of flow periodically, as contrasted to direct current (DC).

A person who is called in or offers to advise a court on some legal matter

Average Megawatt

Air Quality Maintenance Areas

A term with legal definition and application that means any material remains of human life or activities that are at least 100 years of age, and that are of archaeological interest.

The subfield of anthropology engaged in the theory and practice of recovering, analyzing, interpreting, and explaining evidence of the human prehistoric and historic past; the time-depth arm of anthropology. Archaeology as a scholarly endeavor is not limited in the scope of its subject matter by legal or regulatory provisions such as the minimum 
ARTIFACT

ATTAINMENT AREA

AVAILABILITY FACTOR

AVOIDED COST

BACT

BASE LOAD

BASE LOAD STATION

BCA

BIA

BIOLOGICAL ASSESSMENT

BIOLOGICAL OPINION

BLM

BOILER age assigned to archaeological resources (for enforcement purposes) by the Archaeological Resources Protection Act.

Literally, human made, not natural; any object that shows evidence of human manufacture, modification, or use. In common usage, normally refers to portable prehistoric items such as implements made of stone, bone, pottery, or other durable material.

Airshed where state and federal standards for a specific air pollutant are met.

The percentage of time a plant is available for power production.

The payment made for the capacity and energy of a small power project; such payment equals the cost to a utility of obtaining and operating additional generating units, or to purchase power from another source, if this power were not available. Also called avoidable cost.

Best available control technology for control of a specified pollutant.

The amount of electric power needed to be delivered at all times and all seasons.

A power generating station usually operated at a constant output to take all or part of the base load of a system.

Building Codes Agency

Bureau of Indian Affairs

The information concerning listed and proposed species and Critical Habitat and proposed Critical Habitat that may be present in the action area that the federal or designated non-federal representative must gather and evaluate on any major construction activity.

The document that states the opinion of the PWS as to whether or not a federal action is likely to jeopardize the continued existence of listed species or result in the destruction or adverse modification of Critical Habitat.

\section{U.S. Bureau of Land Management}

A closed vessel in which water is heated, steam is generated, steam is superheated, or any combination thereof, under pressure or vacuum by the direct application of heat from the combustion of fuels, or from electricity or nuclear energy. The term shall include fired units for heating or vaporizing liquids other than water where these units are separate from processing systems and are complete within themselves, and related appurtenances. 
BPA

BRITISH THERMAL UNIT

Btu

CANDIDATE SPECIES

CAPACITY

CAPACITY FACTOR

CAPACITY VALUE

CFR

CG

CIRCUIT BREAKER

CLC

CONDITIONAL USE PERMIT (CUP)

COOPERATING AGENCY
Bonneville Power Administration

Quantity of heat required to raise the temperature of one pound of water $1^{\circ} \mathrm{F}$.

See British thermal unit.

Any species being considered by the Secretary of Interior for listing as an endangered species or a threatened species. Separate lists for plants, animals, and invertebrates are published periodically in the Federal Register.

The maximum power output or the load for which a generating unit, generating station, or other electrical apparatus is rated. Common units include kilovolt-ampere $(\mathrm{kVa})$, kilowatt $(\mathrm{kW})$, and Megawatt (MW).

The ratio of the energy that a plant produces to the energy that would be produced if it were operated at full capacity throughout a given period, usually a year. Sometimes called the plant factor.

The part of the market value of electric power that is assigned to dependable capacity.

Code of Federal Regulations, published by the Office of the Federal Registrar, National Archives and Records Service of the General Services Administration.

\section{Cogeneration}

A switch that automatically opens to cut off an electric current when an abnormal condition occurs.

Combined Single Limit

Site outside appropriate zoning class approved for use with conditions.

Any federal agency other than a lead agency which has jurisdiction by law or special expertise with respect to any environmental impact involved in a proposal (or a reasonable alternative) for legislation or other major federal action significantly affecting the quality of the human environment. The selection and responsibilities of a cooperating agency are described in 1501.6. A state or local agency of similar qualifications or, when the effects are on a reservation, an Indian tribe may by agreement with the lead agency become a cooperating agency.

Corps of Engineers

Consumer-owned utility 


\section{COUNCIL}

CRITICAL HABITAT

\section{CULTURAL}

CULTURAL RESOURCE
The Council on Environmental Quality established by Title II of the National Environmental Policy Act.

An area designated as such in the BLM Manual and is any air, land, or water area (exclusive of those existing manmade structures or settlements which are not necessary to the survival and recovery of a listed species) and constituent elements thereof, the loss of which would appreciably decrease the likelihood of the survival and recovery of a listed species or a distinct segment of its population. The constituent elements of Critical Habitat include, but are not limited to: physical structure and topography, biota, climate, human activity, and the quality and chemical content of land, water, and air. Critical Habitat may represent any portion of the present habitat of a listed species and may include additional areas for reasonable population expansion.

Of or pertaining to culture, which is the regularized, patterned, learned behavior shared by members of an interacting social group and passed from generation to generation, comprising the group's technology, economy, religion, arts, social organization, and more; a group's partly subconscious consensus on how things are done. Aspects of culture vary among contemporary groups and change through time. Culture may be viewed as a complex set of instrumental behaviors interposed between a group and its natural and social environment, and may be said to constitute the group's adaptation to its environment.

A broad, general term meaning any cultural property and any traditional lifeway value, as defined below.

1. Cultural Property: a definite location of past human activity, occupation, or use identifiable through field inventory (survey), historical documentation, or oral evidence. The term includes archaeological, historic, or architectural sites, structures, or places with important public and scientific uses, and may include definite locations (sites or places) of traditional cultural or religious importance to specified social and/or cultural groups. Cultural properties are concrete, material places and things that are classified, ranked, and managed through the system of inventory, evaluation, planning, protection, and utilization.

2. Traditional Lifeway Value: the quality of being useful in or important to the maintenance of a specified social and/or cultural group's traditional systems of (a) religious belief, (b) cultural practice, or (c) social interaction, not closely identified with definite locations. Another group's shared values are abstract, non-material, ascribed ideas that one cannot know about without being told. Traditional lifeway values are taken into account through public participation during planning and environmental analysis. 
CUMULATIVE IMPACT

CUP

dBA

DEIS

DEMAND

DESTRUCTION or ADVERSE MODIFICATION

\section{DIRECT BURIAL}

DIRECT CURRENT (DC)

DNS

ECPA

ECOLOGY

EFSC

EFSEC

EIS

ENVIRONMENTAL ASSESSMENT
The impact on the environment which results from the incremental impact of the action when added to other past, present, and reasonable foreseeable future actions regardless of what agency (federal or non-federal) or person undertakes such other actions. Cumulative impacts can result from individually minor but collectively significant actions taking place over a period of time.

\section{Conditional Use Permit}

Decibels A scale, measures of sound levels. ABA LA-50 refers to a weighted sound level.

Draft Environmental Impact Statement

The rate at which electrical energy is delivered to a system, to part of a system, or to a piece of equipment; it is usually expressed in kilowatts, megawatts, etc.

Direct or indirect alteration of Critical Habitat which appreciably diminishes the value of the habitat for both the survival and recovery of a listed species. Such alterations include, but are not limited to, alterations adversely modifying any of those physical or biological features that were the basis for determining the habitat to be critical.

Installing a utility facility underground without encasement by plowing.

Electricity that flows continuously in one direction, as contrasted with alternating current (AC).

Determination of Non Significance

Electric Consumers Protection Act

Washington Department of Ecology

Oregon Energy Facility Siting Council, seven-member council that coordinates and approves siting for large power plants.

Washington's Energy Facility Site Evaluation Council.

Environmental Impact Statement

A concise public document for which a federal agency is responsible that serves to: (1) briefly provide sufficient evidence and analysis for determining whether to prepare an environmental impact statement or a finding of no significant impact; (2) aid an agency's compliance with the Act when no environmental impact statement is necessary; (3) facilitate preparation of a statement when one is necessary. Shall include brief discussions of the need for the proposal, 
ENVIRONMENTAL EFFECTS

ENVIRONMENTAL IMPACT STATEMENT (EIS)

\author{
EXTRA HIGH VOLTAGE \\ (EHV)
}

ER

ESSENTIAL HABITAT

EXCAVATION

EPA

EXPRESSWAY

FEASIBILITY STUDY

FEDERAL ENERGY REGULATORY COMMISSION (FERC) of alternatives as required by section 102(2)(E), of the environmental impacts of the proposed action and alternatives, and a listing of agencies and persons consulted. Also referred to as EA or ER (environmental review).

Direct effects, which are caused by the action and occur at the same time and place. Indirect effects, which are caused by the action and are later in time or farther time or farther removed in distance, but are still reasonably foreseeable. Indirect effects may include growth inducing effects and other effects related to induced changes in the pattern of land use, population density or growth rate, and related effects on air and water and other natural systems, including ecosystems. Effects and impacts are used in [the CEQ] regulations are synonymous. Effects includes ecological (such as the effects on natural resources and on the components, structures, and functioning of affected ecosystems), aesthetic, historic, cultural, economic, social, or health, whether direct, indirect, or cumulative. Effects may also include those resulting from actions which may have both beneficial and detrimental effects, even if on balance the agency believes that the effect will be beneficial.

A detailed written statement as required by section 102(2)(C) of the National Environmental Policy Act.

A term applied to voltage levels of transmission lines that are higher than the voltage levels commonly used. At present, electrical utilities consider EHV to be any voltage of 345,000 volts or higher. See ultrahigh voltages.

See Environmental Assessment.

Criteria for identifying are the same as for Critical Habitat, the only difference being that the area has not been officially designated as Critical Habitat.

The controlled, scientific recovery of subsurface materials and information from a cultural property, through professionally applied archaeological techniques.

\section{U.S. Environmental Protection Agency}

A divided arterial highway for through traffic with full or partial control of access and generally with grade separations at major intersections.

An investigation to develop a project and definitively assess its desirability for implementation.

An agency in the U.S. Department of Energy; regulates the interstate transfer of electrical energy. 
FEIS

FERC

FIXED COSTS

FPA

FREEWAY

FRONTAGE ROAD

FS

FWS

GENERATOR

GIGAWATTHOUR (GWh)

GROUNDWATER

gr/SCF

HABITAT

HIGH PRESSURE, HIGH

TEMPERATURE WATER

BOILER

HIGHWAY, STREET, or ROAD

HISTORIC PRESERVATION

HISTORIC PROPERTY or HISTORIC RESOURCE
Final Environmental Impact Statement.

Federal Energy Regulatory Commission

Costs associated with plant investment, including debt service, interim replacement, and insurance.

Federal Power Act

A divided arterial highway providing access with selected public roads only by prohibiting crossings at-grade or direct private driveway connections. Includes interstate highway system.

A local street or road auxiliary to and located on the side of an arterial highway for service to abutting property and adjacent areas and for control of access.

\section{U.S. Forest Service}

\section{U.S. Fish and Wildlife Service}

A machine that converts mechanical energy into electrical energy.

One million kilowatthours $(\mathrm{kWh})$

The supply of water under the earth's surface, as contrasted to surface water.

Grains of pollutant per standard cubic foot of gas; a measure of dust particles in a gas stream following standard methods.

The place where an organism (plant or animal) lives. There are four major divisions of habitat, namely, terrestrial, freshwater, estuarine, and marine.

A water boiler operating at pressure exceeding 160 psig or temperature exceeding $250^{\circ} \mathrm{F}$.

A general term denoting a public way for purposes of vehicular travel, including the entire area within the right-ofway.

Includes identification, evaluation, recordation, documentation, curation, acquisition, protection, management, rehabilitation, restoration, stabilization, maintenance, reconstruction, or any combination of the foregoing activities.

Any prehistoric or historic district, site, building, structure, or object included in, or eligible for inclusion in, the National Register. The term includes, for purposes of these 


\section{HUMAN ENVIRONMENT}

IDFG

IDHW

IDL

IDLIS

IDPR

IDT

IDWR

INSTALLED CAPACITY

INTERRUPTIBLE ENERGY

INVENTORY regulations, artifacts, records, and remains that are related to and located within such properties. The term 'eligible for inclusion in the National Register' includes both properties formally determined as such by the Secretary of the Interior and all other properties that meet National Register listing criteria.

Interpreted comprehensively to include the natural and physical environment and the relationship of people with that environment. This means that economic or social effects are not intended by themselves to require preparation of an environmental impact statement. When an environmental impact statement is prepared and economic or social and natural or physical environmental effects are interrelated, then the environmental impact statement will discuss all of these effects on the human environment.

Idaho Department of Fish and Game

Idaho Department of Health and Welfare

Idaho Department of Lands

Idaho Department of Labor and Industrial Services

Idaho Department of Parks and Recreation

Idaho Department of Transportation

Idaho Department of Water Resources

The total of the capacities shown on the nameplates of the generating units in a power plant.

Energy that can be curtailed at the purchaser's discretion.

A term used to refer to both a record of cultural resources known to occur within a defined geographic area, and the methods used in developing the record. Depending on intended applications for the data, inventories may be based on (a) compilation and synthesis of previously recorded cultural resource data from archival, library, and other indirect sources; (b) systematic examinations of the land surface and natural exposures of the subsurface (survey) for indications of past human activity as represented by artificial modifications of the land and/or the presence of artifacts; and (c) the use of interviews and related means of locating and describing previously unrecorded or incompletely documented cultural resources, including those that may not be identifiable through physical examination.

Investor-owned Utility

Idaho Power Company 
IPUC

ISHPO

KGRA

KILOWATT (kW)

$\mathrm{kV}$

$\mathrm{kW}$

$\mathrm{kWh}$

LAER

LCDC

LMA

LOA

LOAD

LOAD FACTOR

LUBA

MAJOR FEDERAL ACTION
Idaho Public Utility Commission

Idaho State Historic Preservation Office

Known Geothermal Resource Area

One thousand watthours (Wh) - the amount of electrical energy produced or consumed by a one kilowatt unit for 1 hour.

Kilovolt

Kilowatt

Kilowatt hour

Lowest achievable emissions rate; sets emission limit for non-attainment areas.

Oregon Land Conservation Development Commission, state appointed commission to determine land use policy.

Appropriate Public land Management Agency (BLM, FS NPS, tribe)

Local agencies

The amount of power required at a given point or points in an electric system.

The ratio of the average load to the maximum load during a given period.

Oregon Land Use Board of Appeals; seven-member state body appointed to adjudicate land use disputes.

Actions with effects that may be major and which are potentially subject to federal control and responsibility. Major reinforces but does not have a meaning independent of significantly. Actions include the circumstance where the responsible officials fail to act and that failure to act is reviewable by courts or administrative tribunals under the Administrative Procedure Act or other applicable law as agency action.

Actions include new and continuing activities, including projects and programs entirely or partly financed, assisted, conducted, regulated, or approved by federal agencies; new or revised agency rules, regulations, plans, policies, or procedures; and legislative proposals. Actions do not include funding assistance solely in the form of general revenue sharing funds, distributed under the State and Local Fiscal Assistance Act of 1972, 31 U.S.C. 1221 et seq., with no 
federal agency control over the subsequent use of such funds. Actions do not include bringing judicial or administrative civil or criminal enforcement actions.

MAJOR SOURCE

MCA

MDC

MDFWP

MDHES

MDLI

MDNRC

MDSL

MDT

MEGAWATT (MW)

MITIGATION
Approval of specific projects, such as construction or management activities located in a defined geographic area. Projects include actions approved by permit or other regulatory decision as well as federal and federally assisted activities.

Emissions exceed "significant" rates for non-attainment areas.

Montana Code Annotated

Montana Department of Commerce

Montana Department of Fish, Wildlife, and Parks

Montana Department of Health and Environmental

Sciences

Montana Department of Labor and Industry

Montana Department of Natural Resources and Conservation

Montana Department of State Lands

Montana Department of Transportation

One thousand kilowatts $(\mathrm{kW})$ or one million watts $(\mathrm{W})$.

Avoiding the impact altogether by not taking a certain action or parts of an action.

Minimizing impacts by limiting the degree or magnitude of the action and its implementation.

Rectifying the impact by repairing, rehabilitating, or restoring the affected environment.

Reducing or eliminating the impact over time by preservation and maintenance operations during the life of the action.

Compensating for the impact by replacing or providing substitute resources or environments.

Million kilowatt-hours

Memorandum of Agreement

Memorandum of Understanding 


\section{MPSC}

MSHPO

MSW

MW

NAAQS

NAMEPLATE RATING
Montana Public Service Commission

Montana State Historic Preservation Office

Municipal Solid Waste

Megawatt

National Ambient Air Quality Standards of the U.S. Environmental Protection Agency.

The full-load continuous rating of a generator or other electrical equipment under specified conditions as designated by the manufacturer, and written on the nameplate.
NATIONAL REGISTER OF HISTORIC PLACES

NEGATIVE DECLARATION

NEPA

NEPA PROCESS

NEW UTILITY

INSTALLATIONS

NMFS

NOI

NON-ATTAINMENT AREA
NATIONAL ENVIRONMENTAL POLICY ACT (NEPA)

An act, passed in 1969, requiring that the environmental impact of most projects and programs be identified. Among its important provisions is one requiring a detailed statement of environmental impact of, and alternatives to, a project to be submitted to the federal government before the project can begin.

The National Register of Historic Places, expanded and maintained by the Secretary of the Interior, as authorized by section 2(b) of the Historic Sites Act and section 101(a)(1)(A) of the National Historic Preservation Act. The National Register lists cultural properties found to qualify for inclusion because of their local, state, or national significance. Eligibility criteria and nomination procedures are found in 36 CFR Part 60 . The Secretary's administrative responsibility for the National Register is delegated to the National Park Service.

The document that satisfies the NEPA requirement if no significant environmental impacts would result from a project as determined by an initial study.

National Environmental Policy Act of 1969

All measures necessary for compliance with the requirements of section 2 and Title I of NEPA.

Initial installations on the highway right-of-way and the replacement of existing facilities with those of a different type, capacity, or design or replacement at a new location on the right-of-way.

National Marine Fisheries Service

Notice of Intent

Area that does not meet air quality standards for a specified air pollutant. 
NPDES

NPPC

NPS

NSPS

ODEQ

ODFW

ODLCD

ODOA

ODOE

ODOF

ODOGAMI

ODOT

ODSL

OFF-PEAK

OFFSETS

OLCDC

ON-PEAK

OPUC

OUTAGE

OUTAGE, FORCED

OUTAGE, SCHEDULED

OUTPUT

OWRC
National Pollution Discharge Elimination System, federal water quality program administered by the state agency responsible for water quality.

Northwest Power Planning Council

National Park Service

New Source Performance Standards, from EPA New

Source Review for very large sources of air pollution.

Oregon Department of Environmental Quality

Oregon Department of Fish and Wildlife

Oregon Department of Land Conservation and

Development

Oregon Department of Agriculture

Oregon Department of Energy

Oregon Department of Forestry

Oregon Department of Geology and Mineral Industries

Oregon Department of Transportation

Oregon Division of State Lands

The time of day and week when the demand for electricity is low; see on-peak.

Quantity of air pollutant borrowed from existing permit holder to "offset" pollutants from a new facility.

Oregon Land Conservation and Development Commission

The time of day and week when demand for electricity in a region is high.

Oregon Public Utility Commission

The period during which a facility is out of service.

The shutdown of a facility for emergency reasons.

The shutdown of a facility for inspection or maintenance, as scheduled.

The amount of power or energy delivered from a piece of equipment, a station, or a system.

Oregon Water Resources Commission 
OWRD

PEAKING UNIT

PER

P.L.

PLANT FACTOR

POWER BOILER

PRESSURE VESSEL

PSD

PSI

PSIG

PUC

PUHCA

PURPA

QF

QUAD

QUADRILLION Btu

RCW

RIGHT-OF-WAY
Oregon Water Resources Department

An auxiliary electric power system that is used to supplement the power supply system during periods of peak demand for electricity. Peaking units are usually low-cost, inefficient units having a high fuel cost, or hydroelectric units having low firm capacity.

Preliminary Environmental Review

Public Law

See capacity factor.

An internally fired boiler which is primarily intended for temporary location, the construction and usage of which is obviously portable.

A boiler in which steam or other vapor generated at a pressure of more than $15 \mathrm{psig}$.

Prevention of significant deterioration; air quality for large sources affecting Class I and non-attainment areas.

A unit of pressure as measured in pounds per square inch.

Pounds per square inch gauge

Public Utilities Commission

Public Utility Holding Company Act

Public Utility Regulatory Policies Act of 1978. This act requires utilities to purchase power from and interconnect with a privately developed facility and mandates the state utility regulatory agency to set a "just and reasonable price."

Qualifying Facility

See Quadrillion Btu

An amount of energy equal to the heat value of 965 billion cubic feet of gas, 175 million barrels of oil (DOE), or 38 million tons of coal.

Revised Code of Washington

A general term denoting land, property, or interest therein, usually in a strip, acquired for or devoted to transportation purposes. 
RIPARIAN RIGHTS

ROADWAY

ROYALTY

SBA

SCA

SCS

SELP

SEPA

SHPO

SIGNIFICANT EMISSIONS RATE

SIGNIFICANTLY
The rights of land owners to the water on or bordering their property, including the right to prevent diversion or misuse of upstream water.

The portion of a highway, including shoulders, for vehicular use. A divided highway has two or more roadways.

The portion of the proceeds paid to the title holder in exchange for exploitation of a property.

Small Business Administration

Site Certification Agreement

Soil Conservation Service

Small-Scale Energy Loan Program; Oregon Department of Energy

State Environmental Policy Act

State Historic Preservation Office

Annual rate of emissions for specified pollutant that identifies a "major" air pollution source in DEQ regulations.

As used in NEPA requires considerations of both context and intensity:

1. Context. This means that the significance of an action must be analyzed in several contexts such as society as a whole (human, national), the affected region, the affected interests, and the locality. Significance varies with the setting of the proposed action. For instance, in the case of a site-specific action, significance would usually depend upon the effects in the locale rather in the world as a whole. Both short- and long-term effects are relevant.

2. Intensity. This refers to the severity of impact. Responsible officials must bear in mind that more than one agency may make decisions about partial aspects of a major action. The following should be considered in evaluating intensity:

a. Unique characteristics of the geographic area such as proximity to historic or cultural resources, park lands, prime farmlands, wetlands, wild and scenic rivers, or ecologically critical areas.

b. The degree to which the effects on the quality of the human environment are likely to be highly controversial. 
c. The degree to which the possible effects on the human environment are highly uncertain or involve unique or unknown risks.

d. The degree to which the action may adversely affect an endangered or threatened species or its habitat that has been determined to be critical under the Endangered Species Act of 1973.

SPINNING RESERVE

STATE HISTORIC PRESERVATION OFFICER

SUI GENERIS

SURFACE WATER

SWITCHING STATION

THERM

THERMAL PLANT

THP

TIERING
Generating capacity that is on the line in excess of the load on the system ready to carry additional electrical load.

The official in each state authorized by the state at the request of the Secretary of the Interior to act as a liaison for purposes of implementing the National Historic Preservation Act of 1966.

Unique unto itself

Water on the earth's surface that is exposed to the atmosphere such as rivers, lakes, oceans, as contrasted to groundwater.

An assemblage of equipment used for the sole purpose of typing together two or more electric circuits. Selectively arranged switches are used that permit a circuit to be disconnected in case of trouble or to change electric connections between circuits. A type of substation.

The equivalent of $100,000 \mathrm{Btu}$

An electric generating plant that uses heat to produce electricity. Such plants may burn coal, gas, oil, biomass, or use nuclear energy to produce thermal energy.

Theoretical Horsepower

The coverage of general matters in broader environmental impact statements (such as national program or policy statements) with subsequent narrower statements or environmental analyses (such as regional or basinwide program statements or ultimately site-specific statements) incorporating by reference the general discussions and concentrating solely on the issues specific to the statement subsequently prepared. Tiering is appropriate when the sequence of statements or analyses is: (a) from a program, plan, or policy environmental impact statement to a program, plan, or policy statement or analysis of lesser scope or to a sitespecific statement or analysis; (b) from an environmental impact statement on a specific action at an early stage (such as need and site selection) or a subsequent statement or analysis at a later stage (such as environmental mitigation). Tiering in such cases is appropriate when it helps the lead 
TRADITIONAL LIFEWAY VALUE

TRANSFORMER

TRANSMISSION

TRIBE

UBC

ULTRAHIGH VOLTAGES (UHV)

UMC

URBAN GROWTH

BOUNDARY (UGB)

USFS

USGS

VISUAL QUALITY

WAC

WATERMASTER agency to focus on the issues which are ripe for decision and exclude from consideration issues already decided or not yet ripe.

The quality of being useful in or important to the maintenance of a specified social and/or cultural group's traditional systems of (a) religious belief, (b) cultural practice, or (c) social interaction, not closely identified with definite locations. Another group's shared values are abstract, nonmaterial, ascribed ideas that one cannot know about without being told. Traditional lifeway values are taken into account through public participation during planning and environmental analysis.

A device used to change the voltage of alternating current (AC) electricity.

The act or process of transporting electrical energy in bulk from a source or sources of supply to other principal parts of a system or to other utility systems.

Appropriate Indian Tribe

Uniform Building Code, published by the International Conference of Building Officials. Covers the fire, life, and structural safety aspects of all building and related structures.

Voltages greater than 765,000 volts. See extra high voltage (EHV).

Uniform Mechanical Code; sponsored by the International Association of Plumbing and Mechanical Officials and the International Conference of Building Officials. Contains requirements for the installation and maintenance of heating, ventilating, cooling, and refrigeration systems.

Boundary around cities that provides for future expansion into a county.

\section{U.S. Forest Service}

\section{U.S. Geological Survey}

Shall mean those desirable characteristics of the appearance of the facility and its environment, such as harmony between or blending of natural and manmade objects in the environment, continuity of visual form without distracting interruptions, and simplicity of designs which are desirably functional in shape but without clutter.

Washington Administrative Code

Employed by Oregon Water Resources Department, allocates available surface or groundwater in state. 
WDF

WDNR

WDOC

WDOT

WDSHS

WDSL

WDW

WHEELING

WOAHP

WPCF

WPPSS

WSEO

WUTC
Washington State Department of Fisheries

Washington Department of Natural Resources

Washington State Department of Commerce

Washington State Department of Transportation

Washington State Department of Social and Health Services

Washington Division of State Lands

Washington State Department of Wildlife

The transportation of electricity by an electric utility over its lines for another utility .

Washington State Office of Archaeological and Historic Preservation

Water Pollution Control Facility

Washington Public Power Supply System

Washington State Energy Office

Washington State Utilities and Transportation Commission 



\section{Federal Agencies}

Bonneville Power Administration

P.O. Box 3627

Portland, OR 97208

(503) $230-3000$

Fish and Wildlife Service

Region I

U.S. Fish and Wildlife Service

911 NE 11th Avenue

Portland, OR 97232-4181

(503) 231-6159

\section{Regional Offices}

U.S. Fish and Wildife Service

Boise Field Office

4696 Overland Road, Room 576

Boise, ID 83705

(208) 334-1931

U.S. Fish and Wildlife Service

Portland Field Office

2600 SE 98 th Avenue, Suite 100

Portland, OR 97266

(503) 231-6179

U.S. Fish and Wildlife Service

Olympia Field Office

3704 Griffin Lane, Suite 102

Olympia, WA 98501

(206) 753-9440

U.S. Fish and Wildlife Service

Montana Regional Office

P.O. Box 25486

Denver Federal Center

Denver, CO 82225

(303) 236-7920

Air Quality

Environmental Protection Agency (EPA), Region X 1200 Sixth Avenue

Seattle, WA 98101

(206) 442-1275

EPA, Region I (Idaho, Oregon, Washington)

911 NE 11th Avenue

Portland, OR 97232-4181

(503) 231-6159

Region 8 (Montana)

Environmental Protection Agency

999 18th Street, Suite 500

Denver, CO 80202-2405

(303) 293-1603

Regional Offices

EPA Operations Office

c/o State Department of Ecology

PV-11

Olympia, WA 98504

(206) 459-6000

Oregon Department of Environmental Qualities

811 SW 6th

Portland, OR 97204

(503) 229-5630

$1-800-452-4011$

Idaho Department of Health \& Welfare

Bureau of Air Quality

1410 N Hilton

Boise, ID 83706

(208) 334-5898 
Forest Service

Northern Region

U.S. Forest Service

Northern Region

Federal Building

P.O. Box 7669

Missoula, MT 59807

(406) $329-3518$

National Forest Supervisors' Offices

Colville

Federal Building

695 S Main Street

Colville, WA 99114

(509) 684-3711

Deschutes

1645 Highway $20 \mathrm{E}$

Bend, OR 97701

(503) 388-2715

Fremont

$524 \mathrm{~N}$ "G" Street

P.O. Box 551

Lakeview, OR 97630

(503) 947-2151

Gifford Pinchot

6926 E 4th Plain Boulevard

P.O. Box 8944

Vancouver, WA 98688-8944

(206) 696-7500

Malheur

139 NE Dayton Street

John Day, OR 97845

(503) 575-1731

Mt. Baker-Snoqualmie

1022 First Avenue

Seattle, WA 98104

(206) 442-5400

Mt. Hood

2955 NW Division

Gresham, OR 97030

(503) 666-0700

Umpqua

2900 NW Stewart Parkway

P.O. Box 1008

Roseburg, OR 97470

(502) 672-6601
Intermountain Region

U.S. Forest Service

Intermountain Region

324 25th Street

Ogden, UT 84401

(801) 625-5149

Ochoco

$155 \mathrm{~N}$ Court Street

P.O. Box 490

Prineville, OR 97754

(503) 447-6247

Okanogan

1240 2nd Avenue $S$

P.O. Box 950

Okanogan, WA 98840

(509) 422-2704

Olympic

P.O. Box 2288

Olympia, WA 98507

(206) 753-9534

Rogue River

333 W 8th Street

P.O. Box 520

Medford, OR 97501

(503) 776-3600

Siskiyou

200 NE Greenfield Road

P.O. Box 440

Grants Pass, OR 97526

(503) 479-5301

Siuslaw

4077 Research Way

P.O. Box 1148 (97339

Corvallis, OR 97333

(503) 757-4480

Umatilla

2517 SW Hailey Avenue

Pendleton, OR 97801

(503) 276-3811 
Wenatchee

301 Yakima Street

P.O. Box 811 (98807-0811)

Wenatchee, WA 98801

(509) 662-4335

Winema

2819 Dahlia Street

Klamath Falls, OR 97601

(503) 883-6714

\section{Bureau of Land Management}

State Offices

Alaska

Bureau of Land Management

222 W 7th Avenue, No. 13

Anchorage, AK 99513-7599

(907) 271-5960

Arizona

Bureau of Land Management

3707 N 7th Street

P.O. Box 16563

Phoenix, AZ 85011

(602) 241-5547

California

Bureau of Land Management

Federal Building, Room E-2841

2800 Cottage Way

Sacramento, CA 95825

(916) $978-4754$

\section{Colorado}

Bureau of Land Management

2850 Youngfield Street

Lakewood, CO 80215

(303) 294-2100

Idaho

Bureau of Land Management

3380 Americana Terrace

Boise, ID 83706

(208) 334-1414

Montana (No. Dakota, So. Dakota, Minnesota)

Bureau of Land Management

222 N 32nd Street

P.O. Box 26800

Billing, MT 59107

(406) 255-2885
Wallowa-Whitman

1550 Dewey Avenue

P.O. Box 907

Baker, OR 97814

(503) 523-6391

Willamette

$211 \mathrm{E} 7$ th Avenue

P.O. Box 10607 (97440)

Eugene, OR 97401

(503) 687-6521

Nevada

Bureau of Land Management

850 Harvard Way

P.O. Box 12000

Reno, NV 89520

(702) 328-6300

New Mexico (Kansas, Oklahoma, Texas)

Bureau of Land Management

Federal Building

South Federal Place

P.O. Box 1449

Santa Fe, NM 87501

(505) 988-6000
Oregon (Washington)

Bureau of Land Management

825 NE Multnomah

P.O. Box 2965

Portland, OR 97208

(503) 231-6281

Utah

Bureau of Land Management

Consolidated Financial Center

324 S State Street

Salt Lake City, UT 84111-2302

(801) 539-4001

Wyoming (Nebraska)

Bureau of Land Management

2915 Warren Avenue

P.O. Box 1828

Cheyenne, WY 82001

(307) 772-2273 
Eastern States Office

Bureau of Land Management

350 S Pickett Street

Alexandria, VA 22304

District Offices

Klamath Falls Resource Area

2795 Anderson Avenue, Suite 25

Klamath Falls, OR 97603-7891

(503) 883-6916

Prineville District

185 E 4th Street

P.O. Box 550

Prineville, OR 97754

(503) $447-4115$

Eugene District

1255 Pearl Street

P.O. Box 10226

Eugene, OR 97401

(503) 683-6600

Medford District

3040 Biddle Road

Medford, OR 97501

(503) $770-2200$

Vale District

100 Oregon Street

Vale, OR 97918

(503) 473-3144

Spokane District

E 4217 Main

Spokane, WA 99202

(509) 353-2570

1133 N Western Avenue

Wenatchee Resource Area

Wenatchee, WA 98801

(509) 662-4223

BLM Board of Land Appeals

Office of Hearings and Appeals

Arlington, VA 22203

Office of Environmental Project Review

Department of the Interior

Regional Environmental Officer

Oregon, Washington, Idaho

911 NE 11th Avenue

Portland, OR 97232-4181

(503) 231-6157
Burns District

HC 74-12533 Highway $20 \mathrm{~W}$

Hines, OR 97738

Salem District

1717 Fabry Road SE

Salem, OR 97306

(503) 399-5646

Tillamook Resource Area

6615 Officer's Row

Tillamook, OR 97141

(503) 842-7546

Roseburg District

777 NW Garden Valley Boulevard

Roseburg, OR 97470

(503) 672-4491

Coos Bay District

1300 Airport Lane

North Bend, OR 97459

(503) 756-0100

Baker Resource Area

P.O. Box 987

Baker, OR 97814

(503) 523-6391

Department of Interior

Associate Solicitor

Office of Environmental Affairs

Division of Energy and Resources

Office of the Solicitor

Washington, DC 20240 
Bureau of Reclamation

Regional Director

Pacific Northwest Region

Bureau of Reclamation

Box 043

550 W Fort Street

Boise, ID 83724-0043

(208) 334-1905

Corps of Engineers

District Engineer

U.S. Army Engineer District

Walla Walla, WA 99362

(509) 522-6720

Field Offices

Corps of Engineers

Lucky Peak Project Office

HC-33, Box 1020

Boise, ID 83706

(208) 343-0671

Corps of Engineers

P.O. Box 2946

Portland, OR 97208-2946

(503) 326-6995

National Park Service

Regional Director

Pacific Northwest Region

National Park Service

Attn: Regional Environmental Coordinator

83 S King Street, Suite 212

Seattle, WA 98104

(206) 442-5565

Environmental Protection Agency

Environmental Impact Review Officer

Environmental Protection Agency-Region X

1200 Sixth Avenue

Seattle, WA 98101

(206) $442-1200$

Bureau of Indian Affairs

Director

P. O. Box 10

Phoenix, AZ 85011

(602) 379-6600

Columbia River Intertribal Fishery Commission

975 SE Sandy Boulevard, Suite 202

Portland, OR 97214

(503) 238-0667
Corps of Engineers

c/o Forest Service

1201 Ironwood Drive

Coeur d' Alene, ID 83814

(208) 765-7237

Corps of Engineers (Montana)

215 N 17th Street

Omaha, NE 68102

(402) 221-4125
Director

911 NE 11th Avenue

Portland, OR 97232-4169

(503) 231-6702 
Federal Aviation Administration

Washington \& Oregon Regional Office 1601 Lind Avenue SW

Renton, WA 98055

(206) 227-2001

Boise Airport Traffic Control Tower

3105 Airport Way

Boise, ID 83705

(208) $334-1642$

Federal Communications Commission

Washington, Oregon, Idaho, \& Montana

Building A

11410 NE 122nd Way, Suite 312

Kirkland, WA 98034

(206) 821-9037
Flight Standards District Office

FAA Building

Helena Regional Airport

Helena, MT 59601

(406) 449-5434 


\section{Federal and State Offices - Idaho}

Federal Agencies to Contact for Geothermal Development

Bonneville Power Administration

P.O. Box 3627

Portland, OR 97208

(503) $230-3000$

Fish and Wildlife Service

U.S. Fish and Wildlife Service

Boise Field Office

4696 Overland Road, Room 576

Boise, ID 83705

(208) 334-1931

Forest Service

Northern Region

U.S. Forest Service

Clearwater National Forest

Federal Building

P.O. Box 7669

Missoula, MT 59807

(406) 329-3511

Nez Perce National Forest

Route 2, Box 475

Grangeville, ID 83530

(208) 983-1963

12730 Highway 12

Orofino, ID 83544

(208) $476-4541$

Bitterroot National Forest

$316 \mathrm{~N}$ 3rd Street

Hamilton, MT 59840

(406) 363-3131

Intermountain Region

U.S. Forest Service

324 25th Street

Ogden, UT 84401

(801) 625-5431

Caribou National Forest

250 S 4th Avenue, Suite 294

Pocatello, ID 83201

(208) $236-7500$

Payette National Forest

P.O. Box 1026

McCall, ID 83638

(208) 634-1333

Panhandle National Forest 1201 Ironwood Drive Coeur d'Alene, ID 83814 (208) 765-7223

Boise National Forest 1750 Front Street

Boise, ID 83702

(208) $364-4100$

Challis National Forest

H/C 63, Highway 93

P.O. Box 1671

Challis, ID 83226

(208) 879-2285

Salmon National Forest

P. O. Box 729

Salmon, ID 83467

(208) 756-2215

Sawtooth National Forest

2647 Kimberly Road E

Twin Falls, ID 83301

(208) 737-3200 
Targhee National Forest

420 N Bridge Street

P.O. Box 208

St. Anthony, ID 83445

(208) 624-3151

Bureau of Land Management

U.S. Bureau of Land Management

3380 Americana Terrace

Boise, ID 83706

(208) 334-1414

\section{District Offices}

Boise District Office

3948 Development Avenue

Boise, ID 83705

(208) 334-1582

Idaho Falls District Office

940 Lincoln Road

Idaho Falls, ID 83401

(208) $529-1020$

Shoshone District Office

P. O. Box 2-B

Shoshone, ID 83352

(208) 886-2206

Office of Environmental Project Review

Department of the Interior

Office of Environmental Affairs

911 NE 11th Avenue

Portland, OR 972324181

(503) 231-6157

Bureau of Reclamation

Pacific Northwest Region

Bureau of Reclamation

Box 043

$550 \mathrm{~W}$ Fort Street

Boise, ID 83724-0043

(208) 334-1905

Corps of Engineers

District Engineer

U.S. Army Engineer District

Walla Walla, WA 99362

(509) 522-6720
Burley District Office

Route 3, Box 1

Burley, ID 83318

(208) 678-5514

Salmon District Office

P. O. Box 430

Salmon, ID 83467

(208) 756-5400

Coeur d'Alene District Office

1808 N 3rd Street

Coeur d'Alene, ID 83814

(208) 765-1511 
Idaho Field Offices

Corps of Engineers

Lucky Peak Project Office

HC-33, Box 1020

Boise, ID 83706

(208) 343-0671

National Park Service

Regional Director

Pacific Northwest Region

National Park Service

Attn: Regional Environmental Coordinator

83 S King Street, Suite 212

Seattle, WA 98104

(206) 442-5565

Environmental Protection Agency

Environmental Impact Review Officer

Environmental Protection Agency-Region X

1200 Sixth Avenue

Seattle, WA 98101

(206) 442-1200

\section{Bureau of Indian Affairs}

Director

P. O. Box 10

Phoenix, AZ 85011

(602) $379-6600$

Columbia River Intertribal Fishery Commission

975 SE Sandy Boulevard, Suite 202

Portland, OR 97214

(503) 238-0667

Federal Aviation Administration

Boise Airport Traffic Control Tower

3105 Airport Way

Boise, ID 83705

(208) 334-1642

\section{State Agencies to Contact for Geothermal Development}

\section{Water Resources}

Idaho Department of Water Resources

Statehouse Mail

1301 N Orchard Street

Boise, ID 83720

(208) 327-7900
Corps of Engineers

c/o Forest Service

1201 Ironwood Drive

Coeur d'Alene, ID 83814

(208) 765-7237
Director

911 NE 11th Avenue

Portland, OR 97232-4169

(503) 231-6702 
Regional Offices of Water Resources

Northern Region

1910 NW Boulevard, Suite 210

Coeur d'Alene, ID 83814

(208) 765-4639

Eastern Region

150 Shoup, Suite 15

Idaho Falls, ID 83402

(208) 525-7161

Department of Fish and Game

Idaho Department of Fish and Game

600 S Walnut Street

P. O. Box 25

Boise, ID 83707

(208) 334-3771

\section{Regional Offices}

Region 1

2320 Government Way

Coeur d'Alene, ID 83814

(208) 765-3111

Region 3

109 W 44th Street

Boise, ID 83714

(208) 327-7025

\section{Region 4}

868 E Main

P O. Box 428

Jerome, ID 83338

(208) $324-4359$

Region 6

1515 Lincoln Road

Idaho Falls, ID 83401

(208) 525-7290

Department of Parks and Recreation Idaho Department of Parks and Recreation Statehouse Mail

Boise, ID 83720

(208) 334-2154

\section{Public Utilities Commission}

Idaho Public Utilities Commission

$472 \mathrm{~W}$ Washington

Boise, ID 83702

(208) 334-0300
Southern Region

222 Shoshone Street E

Twin Falls, ID 83301

(208) 734-3578

Western Region

2735 Airport Way

Boise, ID 83705

(208) 334-2190

\author{
Region 2 \\ 1540 Warner Avenue \\ Lewiston, ID 83501 \\ (208) 743-6502 \\ McCall Subregion \\ P. O. Box 905 \\ McCall, ID 83638 \\ (208) 634-8137 \\ Region 5 \\ 1345 Barton Road \\ Pocatello, ID 83204 \\ (208) 232-4703
}

Salmon Subregion

P. O. Box 1336

Salmon, ID 83467

(208) 756-2271 
Idaho State Historic Preservation Office Idaho State Historical Society

210 Main Street

Boise, ID 83702

(208) 334-3847

Department of Health and Welfare

Division of Environmental Quality

Department of Health and Welfare

1410 N Hilton, Suite 101

Boise, ID 83720

(208) 334-5867

Field Offices

Coeur d'Alene Field Office

2110 Ironwood Parkway

Coeur d'Alene, ID 83814

(208) 667-3524

Pocatello Field Office

224 S Arthur

Pocatello, ID 83204

(208) 236-6160

Department of Lands

Idaho Department of Lands

Statehouse Mail, Room 121

Boise, ID 83720

(208) $334-3280$

Department of Labor and Industrial Services

Statehouse Mail

277 N 6th

Boise, ID 83720

(208) $334-3950$

Transportation Department

Idaho Transportation Department

P. O. Box 7129

Boise, ID 83707

(208) $334-8000$
Lewiston Field Office

1118 F Street

Lewiston, ID 83501

(208) 799-3430

Twin Falls Field Office

P. O. Box 1626

Twin Falls, ID 83303

(208) 734-9520 


\section{Montana State Agencies}

Department of Natural Resources and Conservation

Cogswell Building

$1520 \mathrm{E}$ Sixth Avenue

Helena, MT 59620

(406) 444-6699

\section{Building Codes Bureau}

1218 E Sixth Avenue

Helena, MT 59620

(406) 444-3494

Department of Commerce

1424 Ninth Avenue

Helena, MT 59620

(406) 444-3494

Board of Natural Resources and Conservation

Cogswell Building

1520 E Sixth Avenue

Helena, MT 59620

(406) 444-6699

Department of Health \&

Environmental Sciences

Cogswell Building

1520 E Sixth Avenue

Helena, MT 59620

(406) 444-3948

Water Rights Bureau

Field Offices

Bozeman

111 N Tracy

Bozeman, MT 59715

(406) 586-3136

Missoula

Holiday Village Professional Plaza

Suite 105

P.O. Box 5004

Missoula, MT 59806

(406) $721-4284$

\section{Havre}

$1708 \mathrm{~W}$ 2nd Street

P.O. Box 1828

Harve, MT 59501

(406) 265-5516
Helena

1520 E Sixth Avenue

Helena, MT 59620

(406) 444-6695

Kalispell

3220 Highway $93 \mathrm{~S}$

P.O. Box 860

Kalispell, MT 59903-0860

(406) 752-2288

Glasgow

839 1st Avenue S

P.O. Box 1269

Glasgow, MT 59230

(406) 228-2561 
Lewistown

204 S Daws

P.O. Box 438

Lewistown, MT 59457

(406) 538-7459

Billings

1537 Avenue D, Suite 105

Billings, MT 59102

(406) 657-2105

State Historic Preservation Office

Montana Historical Society

225 N Roberts

Helena, MT 59620

(406) 444-7715

Department of State Lands

1625 Eleventh Avenue

Helena, MT 59620

(406) 444-2074

Board of Land Commissioners

1625 Eleventh Avenue

Helena, MT 59620

(406) 444-2074

Department of Fish, Wildlife, and Parks

1420 E Sixth Avenue

Helena, MT 59620

(406) 444-3186

Department of Transportation

2701 Prospect Avenue

Helena, MT 59620

(406) 444-6201

Department of Labor and Industry

Lockey and Roberts

Helena, MT 59620

(406) 444-3555
Miles City

5 N Prairie Avenue

P.O. Box 276

Miles City, MT 59301

(406) 232-6359 


\section{Oregon Addresses}

Building Codes Agency

1535 Edgewater NW

Salem, Oregon 97310

(503) 373-1248

(503) $378-3290$

Fire Marshall

3000 Market Street NE, Suite 534

Salem, Oregon 97310

(503) $378-4580$

Boiler Inspection \& Licensing

Building Codes Agency

1535 Edgewater Road NW

Salem, OR 97310

(503) $378-3290$

Energy Facility Siting Council

Department of Energy

625 Marion NE

Salem, Oregon 97310

(503) 378-4129

Public Utility Commissioner

Utilities Program

Labor \& Industries Building, Room 330

Salem, Oregon 97310

(503) 378-6634

Oregon Water Resources Department

3850 Portland Road NE

Salem, Oregon 97310

(503) 378-3739

Water Resources Department

3850 Portland Road NE

Salem, OR 97310

(503) 370-3739

Department of Geology and Mineral Industries

910 State Office Building

1400 SW 5th

Portland, OR 97201

(503) 229-5580

Department of Environmental Quality

811 SW Sixth

Portland, OR 97204

(503) 229-5696 
Department of Fish and Wildlife

2501 SW First Avenue

Box 59

Portland, OR 97207

(503) 229-5400

Economic Development Department

775 Summer Street NE

Salem, OR 97310

(503) $373-1200$

Department of Agriculture

Plant Conservation Biology Program

625 Capitol Street NE

Salem, OR 97310-0110

(503) $378-3810$

Columbia River Gorge Commission

288 E Jewett Boulevard

Box 730

White Salmon, WA 98672

(509) 493-3323

Oregon Department of Energy

625 Marion Street NE

Salem, OR 97310

(503) $378-4040$

Oregon Parks and Recreation Department

Vick Building

525 Trade Street SE \#301

Salem, OR 97310

(503) 378-6305

Advisory Committee on Historic Preservation

525 Trade Street SE

Salem, OR 97310

(503) $378-5001$

Oregon Department of Forestry

State Board of Forestry

2600 State Street

Salem, OR 97310

(503) $378-2511$

Oregon Department of Transportation

Oregon Transportation Commission

135 Transportation Building

Salem, OR 97310

(503) $378-6388$ 
Oregon Division of State Lands

State Land Board

775 Summer Street

Salem, OR 97310

(503) $378-3850$

Oregon Water Resources Department District Offices

District

1

4

5

6

7

8

9

10
Hood River, Sherman, Wasco

Baker

Counties

Clatsop, Columbia, Tillamook, Washington

Lane, Linn

Gilliam, Grant, Wheeler

Morrow, Umatilla

Union

Wallowa

Malheur

Harney
Address

Washington County Courthouse

$155 \mathrm{~N}$ 1st Avenue

Hillsboro, OR 97123

(503) 681-7018

Lane County Courthouse

Environmental Health Department $125 \mathrm{E}$ 8th

Eugene, OR 97401

(503) 687-4011

Wasco County Courthouse Annex A 400 E 5th

The Dalles, OR 97058

(503) 296-5494

P.O. Box 261

Canyon City, OR 97820

575-0119

3920 Westgate

Pendleton, OR 97801

276-7111

Route 1, Box 1709

La Grande, OR 97850

(503) $963-1010$

Wallowa County Courthouse

Enterprise, OR 97828

426-4216

Baker County Courthouse 1995 3rd Street Baker, OR 97814

(503) $523-8224$ or $523-7866$

Malheur County Courthouse

Vale, OR 97918

(503) $473-5130$

Harney County Courthouse

P.O. Box 1147

Burns, OR 97720

(503) 573-2591 
11

Crook, Deschutes,

Jefferson

12

Lake

13

Jackson

14

Josephine

15

16

17

18
Klamath

Coos, Curry, Douglas

Clackamas, Marion, Multnomah

Benton, Lincoln, Polk, Yamhill
117 E NW Lafayette

Bend, OR 97701

(503) 388-6669

513 Center Street

Lakeview, OR 97630

(503) 947-6038

Jackson County Courthouse

10 S Oakdale, Room 106

Medford, OR 97501

(503) 776-7056

Grants Pass Municipal Building

101 NW "A" Street

Grants Pass, OR 97526

(503) 474-5385

Justice Building, Room 103

Roseburg, OR 97470

(503) 440-4255

3850 Portland Road NE

Salem, OR 97310

(503) 378-8128

3328 Vandenberg Road

Klamath Falls, OR 97603

(503) 883-4182

3850 Portland Road NE

Salem, OR 97310

(503) 378-8128

Oregon County Planning Departments

County

Baker

Benton

Clackamas

Clatsop

Columbia

Coos

Crook

Curry

Deschutes

Douglas

Gilliam

Grant

Harney

Hood River

Jackson

Jefferson

Josephine
County Seat

Baker City

Corvallis

Oregon City

Astoria

St. Helens

Coquille

Prineville

Gold Beach

Bend

Roseburg

Condon

Canyon City

Burns

Hood River

Medford

Madras

Grants Pass
Telephone

523-6414

757-6819

655-8521

325-8611

397-1501

396-3121

447-3211

247-7011

388-6556

672-3311

384-4243

575-1519

573-6655

386-1306

776-7554

475-2317

474-5421 
Klamath

Lake

Lane

Lincoln

Linn

Malheur

Marion

Morrow

Multnomah

Polk

Sherman

Tillamook

Umatilla

Union

Wallowa

Wasco

Washington

Wheeler

Yambill
Klamath Falls

Lakeview

Eugene

Newport

Albany

Vale

Salem

Irrigon

Portland

Dallas

Moro

Tillamook

Pendleton

La Grande

Enterprise

The Dalles

Hillsboro

Fossil

McMinnville
882-2501

947-4494

687-4061

265-6611

967-3816

473-3185

588-5038

676-9061

248-3043

623-9237

565-3606

842-5511

276-7111

963-1014

426-3048

298-5169

648-8761

763-2911

472-9371 


\section{Washington State Agency Addresses}

Washington Department of Natural Resources 201 John A. Cherberg Building

QW-21

Olympia, WA 98504

(206) 753-5327

Geology \& Earth Resources Division

4224 Sixth Avenue SE

Rowe Six Building, PY-12

Lacey, WA 98503

(206) 459-6372

\section{Regional Offices}

Central Region

1405 Rush Road S-3

Chehalis, WA 98532

(206) 753-3410

Northwest Region

919 N Township Street

Sedro Woolley, WA 98284

(206) 856-0083

South Puget Sound Region

28329 SE 448th Street

Enumclaw, WA 98022

(206) 825-1631

Southwest Region

601 Bond Road

Castle Rock, WA 98611

(206) 577-2025

Washington State Energy Office

809 Legion Way SE, FA-11

Olympia, WA 98504

Department of Ecology

Main Office

PV-11

Olympia-Lacey, WA 98504

(206) $459-6000$

\section{Regional Offices}

Eastern

N 4601 Monroe, Suite 100

Spokane, WA 99205-1295

(509) 456-2926
Forest Regulation \& Assistance 1007 S Washington, EL-03

Olympia, WA 98504

(206) 753-5315

Northeast Region

P.O. Box 190

Colville, WA 99114

(509) 684-5201

Olympic Region

Route 1, Box 1375

Forks, WA 98331

(206) 374-6131

Southeast Region

713 E Bowers Road

Ellensburg, WA 98926

(509) 925-6131
Central

$3601 \mathrm{~W}$ Washington

Yakima, WA 98903-1164

(509) 575-2800 
Department of Fisheries

115 General Administration Building

AX-11

Olympia, WA 98504

(206) 753-6600

Parks and Recreation Commission

600 N Capitol Way, GJ-11

Olympia, WA 98504

(206) 753-5755

Department of Social and Health Services

Environmental Health Division

Mail Stop LD-11

Olympia, WA 98504

(206) 753-5955

Department of Wildlife

600 Capitol Way N

GJ-11

Olympia, WA 98501-1091

(206) 753-5700

Energy Facility Site Evaluation Council 809 Legion Way SE

FA-11

Olympia, WA 98504-1211

(206) $956-2000$

Air Quality

Department of Social and Health Services

Twelfth \& Franklin, OB-22

Olympia, WA 98504

(206) 753-7039

Puget Sound Air Pollution Control Agency

200 W Mercer Street, Room 205

Seattle, WA 98119-3958

(206) 296-7330

Spokane County Air Pollution Control Authority

W 1101 College Avenue, Room 230

Spokane, WA 99201

(509) 456-4727

Grant County Clean Air Authority

P.O. Box 37

Ephrata, WA 98823

(509) 754-4313

NW Regional Office (San Juan County

4350 150th Avenue NE

Redmond, WA 98052-5301

(206) $867-7100$
Olympic Air Pollution Control Authority

120 E State Avenue

Olympia, WA 98502

(206) $352-4881$

Southwest Air Pollution Control Authority 1308 NE 134th Street, Suite D

Vancouver, WA 98685

(206) 574-3058

Yakima County Clean Air Authority

209 County Courthouse

North Second \& East B Street

Yakima, WA 98901

(509) 575-4116

Air Pollution Control Authority

650 George Washington Way

Richland, WA 99352

(509) 545-2354 
Office of Archaeological and Historic Preservation

111 W 21st Avenue

KL-11

Olympia, WA 98504

(206) 753-4011

U.S. Forest Service

1835 Black Lake Boulevard SW

Olympia, WA 98502

(206) 956-2306 



\section{Indian Tribes of the Northwest}

Idaho Indian Tribes

Chairman

Nez Perce Executive Committee

Nez Perce Tribe

P. O. Box 305

Lapwai, ID 83540

(208) 843-2253

Shoshone-Bannock Tribe

P. O. Box 306

Fort Hall, ID 83203

(208) 238-3700

Montana Indian Tribes

Assiniboine and Sioux Tribes

Fort Peck Agency

P.O. Box 1027

Poplar, MT 59255

(406) 768-5155

Confederated Salish \& Kootenai Tribes

P.O. Box 278

Pablo, MT 59855

(406) 657-2700

Fort Belknap Community Council

P.O. Box 249

Harlem, MT 59526

(406) 353-2205

Chippewa Cree Tribe

Rocky Boy's Agency

Rocky Boy Route, Box 544

Box Elder, MT 59521

(406) $395-4478$

Oregon Indian Tribes

Confederated Tribes of Coos,

Lower Umpqua, \& Sluslaw Indians

455 S 4th Street

Coos Bay, OR 97420-1570

(503) 267-5454

Coquille Indian Tribe

P.O. Box 1435

Coos Bay, OR 97420-0330

(503) 267-5454
Shoshone-Paiute Tribe of the

Duck Valley Reservation

P. O. Box 219

Owyhee, NV 89832

(702) 757-3211

Coeur d'Alene Tribal Headquarters

Sub-Agency

Plummer, ID 83851

(208) 274-3101

Blackfeet Nation

P.O. Box 846

Browning, MT 59417

(406) 338-7179

Crow Tribal Council

Box 159

Crow Agency, MT 59022

(406) 638-2601

Northern Cheyenne Tribal Council

P.O. Box 128

Lame Deer, MT 59043

(406) 477-6284
Confederated Tribes of the Grand Ronde

Community of Oregon

P.O. Box 38

Grand Ronde, OR 97347-0038

(503) 879-5215

Cow Creek Band of Umpqua Tribe

2400 Stewart Parkway, Suite 300

Roseburg, OR 97470-1563

(503) 672-9405 
Siletz Tribal Council

P.O. Box 549

Siletz, OR 97380-0549

(503) 444-2532

Confederated Tribes of Warm Springs

H.C. 71

100 Pasigo Street

Burns, OR 97720-9303

(503) 573-2088

Washington Indian Tribes

Chehalis Confederated Tribes

P.O. Box 536

Oakville, WA 98568

(206) 273-5911

Hoh Tribe

HC 80 Box 917

Forks, WA 98331

(206) 374-6582

Kalispel Tribe

P.O. Box 38

Usk, WA 99180

(509) 445-1147

Lummi Tribe

2616 Kwina Road

Bellingham, WA 98226-9298

(206) 643-6242

Muckleshoot Tribe

39015 172nd Avenue SE

Auburn, WA 98002

(206) 939-3311

Nooksack Tribe

P.O. Box 157

Deming, WA 98244

(206) $592-5176$

Puyallup Tribe

2002 E 28th Street

Tacoma, WA 98404

(206) $597-6200$

Quinault Tribe

P.O. Box 189

Taholah, WA 98587

(206) 276-8211
Umatilla Tribe

P.O. Box 638

Pendleton, OR 97801-0638

(503) 276-3165
Colville Confederated Tribes

P.O. Box 150

Nespelem, WA 99155

(509) 634-4763

Jamestown Klallam Tribe

305 Oly Blyn Highway

Sequim, WA 98382

(206) 683-1109

Lower Elwha Klallam Tribe

1666 Lower Elwha Road

Port Angeles, WA 98362-0298

(206) 452-8471

Makah Tribe

P.O. Box 115

Neah Bay, WA 98357

(206) 645-2205

Nisqually Tribe

4820 She-Nah-Num D. SE

Olympia, WA 98503

(206) 456-5221

Port Gamble Klallam Tribe

P.O. Box 280

Kingston, WA 98346

(206) 297-2646

Quileute Tribe

P.O. Box 279

La Push, WA 98350

(206) 374-6143

Sauk-Sueittle Tribe

5318 Chief Brown Lane

Darrington, WA 98241

(206) 436-0132 
Shoalwater Bay Tribe P.O. Box 597 Tokeland, WA 98590 (206) 267-6766

Spokane Tribe

P.O. Box 100

Wellpinit, WA 99040

(509) 258-4591

Stillaguamish Tribe 3439 Stoluckguamish Lane Arlington, WA 98223

(206) 435-2755

Swinomish Tribe

P.O. Box 817

LaConner, WA 98257

(206) 466-3163

Upper Skagit Tribe 2284 Community Plaza

Sedro Woolley, WA 98284 (206) 856-5501
Skokomish Tribe

N 541 Tribal Center Road

Shelton, WA 98584

(206) 877-5213

Squaxin Island Tribe

W 81 Highway 108

Shelton, WA 98584

(206) 426-9783

Suquamish Tribe

P.0. 498

Suquamish, WA 98392

(206) 598-3311

Tulalip Tribes

6700 Totem Beach Road

Marysville, WA 98270-9694

(206) 653-0223

Yakima Confederated Tribes

P.O. Box 151

Toppenish, WA 98948

(509) 865-5121 